$$
\text { UNIVERSIDADE DE SÃO PAULO }
$$

FACULDADE DE FILOSOFIA, LETRAS E CIÊNCIAS HUMANAS

DEPARTAMENTO DE LETRAS CLÁSSICAS E VERNÁCULAS

PROGRAMA DE PÓS-GRADUAÇÃO EM LITERATURA BRASILEIRA

\title{
PARA FORMAR OS BRASILEIROS. O COMPÊNDIO DA HISTÓRIA DO BRASIL DE ABREU E LIMA E A EXPANSÃO PARA DENTRO DO IMPÉRIO DO BRASIL
}

Selma Rinaldi de Mattos

Tese apresentada ao Programa de PósGraduação em História Social, do Departamento de História da Faculdade de Filosofia, Letras e Ciências Humanas da Universidade de São Paulo, para obtenção do título de Doutor em História Social.

Orientador: Profa. Dra. Maria Lígia Coelho Prado 
UNIVERSIDADE DE SÃO PAULO

FACULDADE DE FILOSOFIA, LETRAS E CIÊNCIAS HUMANAS

DEPARTAMENTO DE LETRAS CLÁSSICAS E VERNÁCULAS

PROGRAMA DE PÓS-GRADUAÇÃO EM LITERATURA BRASILEIRA

\section{PARA FORMAR OS BRASILEIROS. O COMPÊNDIO DA HISTÓRIA DO BRASIL DE ABREU E LIMA E A EXPANSÃO PARA DENTRO DO IMPÉRIO DO BRASIL}

Selma Rinaldi de Mattos 


\section{Para}

Carlos, Pedro e Bruno

Pelo aconchego dos seus pequeninos braços onde me aninho e me refaço. 


\section{AGRADECIMENTOS}

No começo havia um tema e diversas questões, um projeto tal qual uma carta de intenções. A trajetória foi longa, mas no essencial pouco a pouco se fez texto, no incansável desafio da reescritura. $\mathrm{O}$ respeito às regras e ao bom senso sinalizaram a importância de terminar o trabalho, pôr um ponto final e guardar para mais tarde idéias que desejavam se impor em hora tardia.

A escritura de uma tese acontece em meio à vida. E das relações que dão sentido ao viver, se torna devedora.

A finalização do texto permite tanto liberar amarras antes necessárias e importantes como possibilita um rememorar emocionado. Corro o risco de não saber dizer o quanto foi importante para mim uma sugestão de leitura, uma palavra, uma frase plena de significado, um ombro amigo, a lembrança de uma citação desconhecida, um xerox de última hora, o convite para um café, um livro ofertado, um abraço solidário, um atendimento atencioso e competente, uma crítica perfeita na hora certa, uma ajuda providencial nas tarefas cotidianas...

Agradeço, em primeiro lugar, a Maria Lígia Coelho Prado a orientação instigante, pontuada por uma atenção generosa e sensível. Agradeço a confiança que depositou em mim, liberando-me para percorrer vários caminhos, fazer escolhas, tramar uma trajetória e ser por ela responsável.

Em especial, sou grata a Márcia de Almeida Gonçalves pelo tempo da conversa sobre o Brasil do XIX e a vida no XXI, as sugestões de leitura, a disponibilidade afetiva, a competência teórica; a Maria Elisa Mader pela solidariedade delicada e constante, as conversas sobre a idéia de nação no Brasil e nas Américas do XIX, mesmo às vésperas de seu próprio doutoramento; a Margarida de Souza Neves, amiga de todas as horas, pelo afeto irrestrito, o incentivo sem lacunas, constante e apaixonado; a Luis Reznik pelo gosto que nos aproxima e identifica aos livros escolares e ao ensino de história e sobretudo pela amizade inquestionável que um dia construímos; a Marco Antônio Villela Pamplona pelas sugestões 
de leitura, o olhar atento, a amizade e companheirismo, bem comum que nos aproxima desde os tempos de graduação.

A Alda Heizer, Heloíza Sezerdelo Correia, Luís Afonso Seigneur de Albuquerque e Roberto d’Affonseca Gusmão, amigos e cúmplices, sou grata por cultivarem uma enorme delicadeza de sentimentos e o dom da conversa prazerosa.

A Eunícia Barros B. Fernandes, Ivana Stolze Lima, Luciana Borgerth Vial Corrêa e Maria Teresa Chaves de Mello, agradeço o incentivo, o carinho e o companheirismo.

Um muito especial obrigada a Flávia Maria Eyler por ter contribuído para a realização deste trabalho ao me presentear com o primeiro tomo do Compêndio de Abreu e Lima, livro que pertencia à sua família; à generosa solidariedadede Antônio Edmilson Martins Rodrigues; e a Valdei Lopes de Araújo, por sugestões de leitura.

A Anair de Oliveira, Cleuza Ventura, Cláudio Santiago de Araújo e Edna Timbó, um quarteto acima do bem e do mal, sou muito agradecida pelas incontáveis ajudas, o riso que alegra, o abraço amigo, a alma generosa, o estarmos juntos há tantos anos.

Agradeço a Íris Ângela Alves de Oliveira e Leandro Macedo Jank a realização de parte significativa da pesquisa documental, e também a Priscila Vizeu Mancuso, a Carolina de Souza Pousa e Nathália Peixoto B. de Souza.

Ao Departamento de História da PUC-Rio, instituição que me acolheu como aluna de graduação e anos mais tarde como professora, minha gratidão e apreço a todos os professores, funcionários e alunos.

Sou grata ao Programa de Pós Graduação em História Social da FFLCH da USP, em especial ao professor Modesto Florenzano. A mestria de suas aulas tornou as viagens semanais que me levavam a São Paulo mais curtas, menos estafantes e com certeza muito proveitosas. 
A Pedro Tórtima, do Instituto Histórico e Geográfico Brasileiro, agradeço a atenção e solicitude que distinguem o trabalho que realiza. A Vera Cabana, do NUDOM, o meu agradecimento pelo atendimento cuidadoso que em muito facilitou a pesquisa documental; aos funcionários do setor de Obras Raras da Biblioteca Nacional, muito obrigada.

A Márcia Rinaldi de Mattos, Patrícia Cardoso e Renato Crivano pelo olhar precioso e atenção cuidadosa.

Meu carinho e bem-querer a Luiza Irene do Nascimento pelo simples fato de ser como é, e ter um dia chegado às nossas vidas.

A Ilma amiga de toda vida e de todos os momentos.

A Roberta pela amizade que nos une, a delicadeza e o gosto pela história; a Renato amigo sensível sempre presente e comprometido.

A Márcia, Rodrigo e João filhos queridos, amigos preciosos, - amores irreversíveis.

A Ilmar por tantos mares navegados, o gosto permanente pela viagem, - sempre.

Para Carlos, Pedro e Bruno, netos nascidos no tempo da tese, - todo o sentimento do mundo. 


\section{SUMÁRIO}

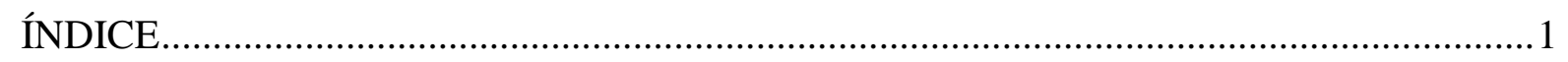

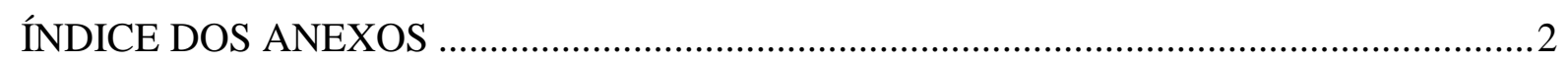

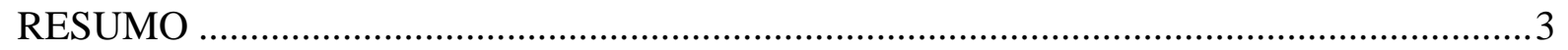

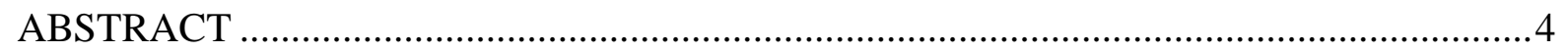

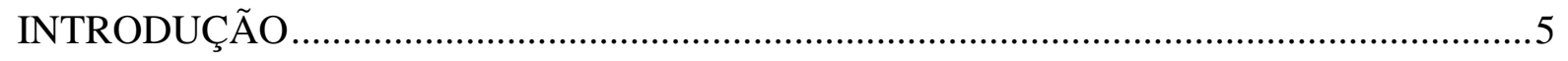

CAPÍTULO I NEM DOM QUIXOTE NEM SANCHO PANÇA ........................................ 10

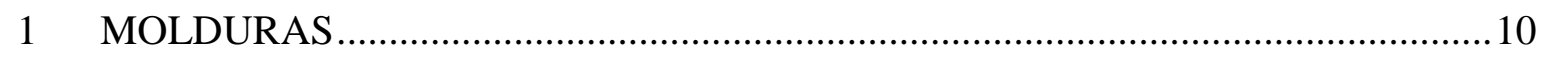

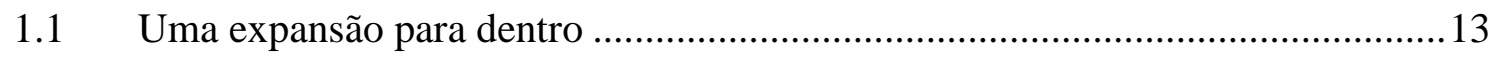

2 DE UM CERTO JOSÉ INÁCIO A ABREU E LIMA ............................................23

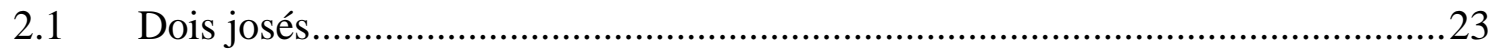

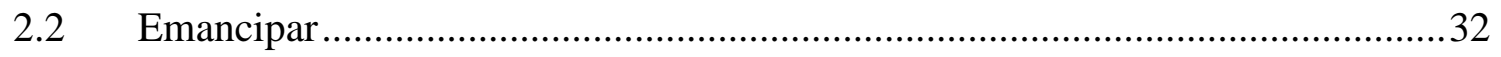

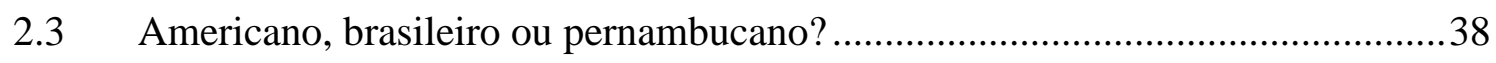

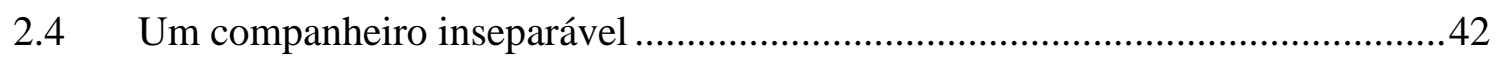

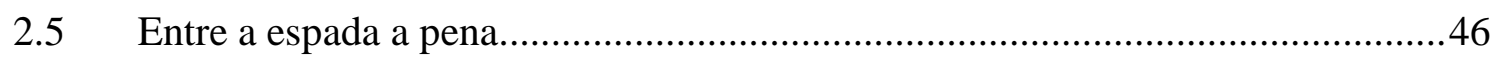

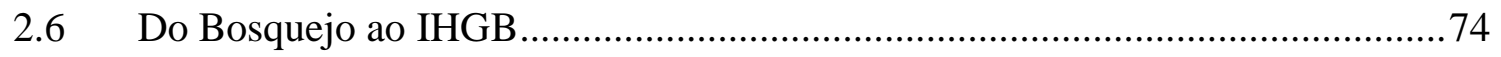

CAPÍTULO II UM COMPÊNDIO DA HISTÓRIA DO BRASIL ........................................85

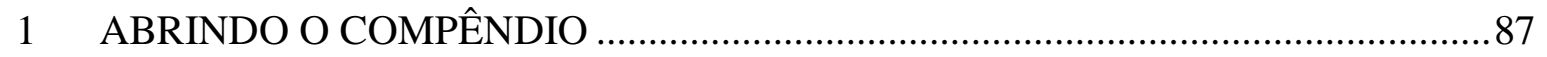

2 EDITORES E EDIÇÕES: UM JOGO DE INTENÇÕES ….................................. 100

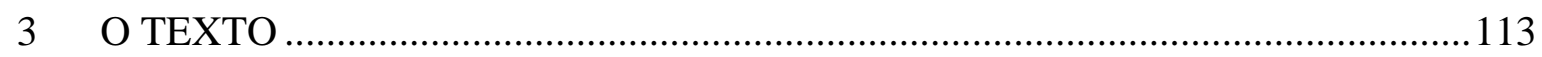

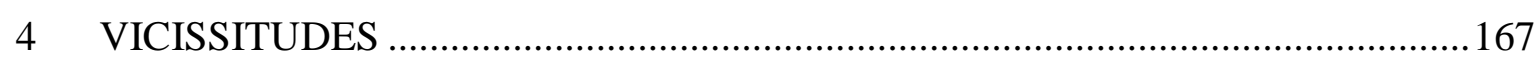

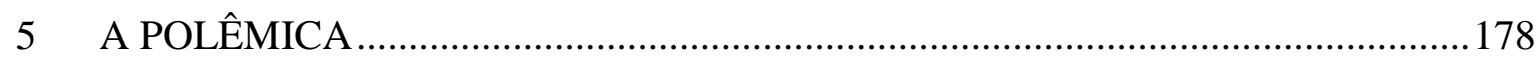

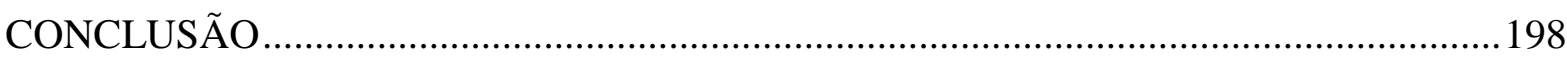

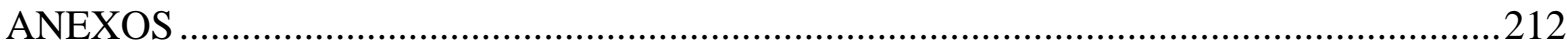

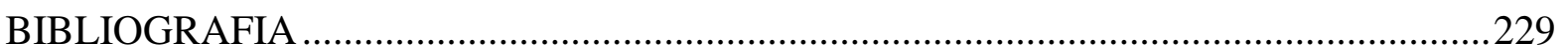




\section{ÍNDICE}

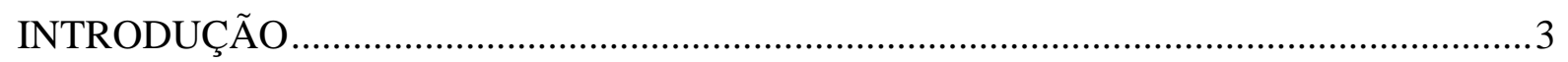

CAPÍTULO I NEM DOM QUIXOTE NEM SANCHO PANÇA ……………………............10

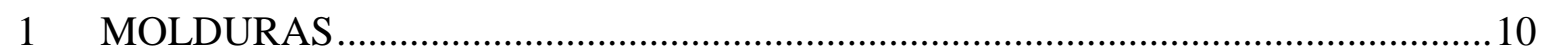

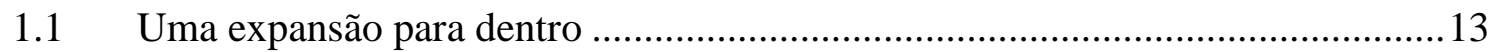

2 DE UM CERTO JOSÉ INÁCIO A ABREU E LIMA ………………………….........23

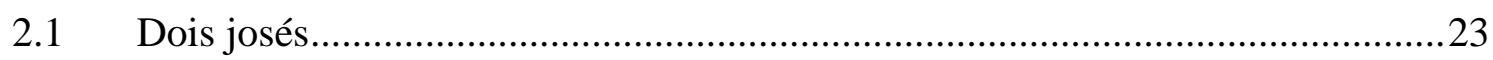

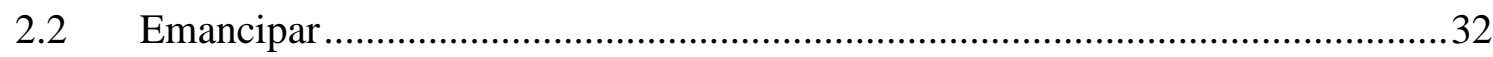

2.3 Americano, brasileiro ou pernambucano? .........................................................38

2.4 Um companheiro inseparável ........................................................................42

$2.5 \quad$ Entre a espada a pena....................................................................................46

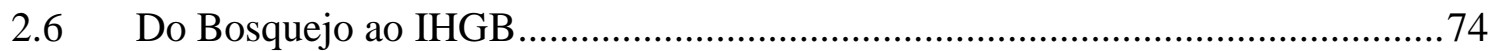

CAPÍTULO II UM COMPÊNDIO DA HISTÓRIA DO BRASIL ……...................................85

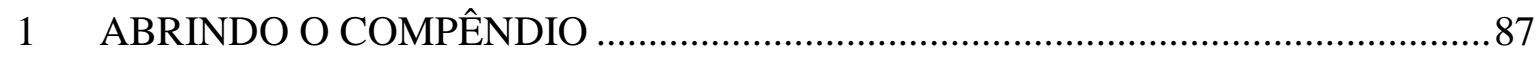

2 EDITORES E EDIÇÕES: UM JOGO DE INTENÇÕES ……………………….......100

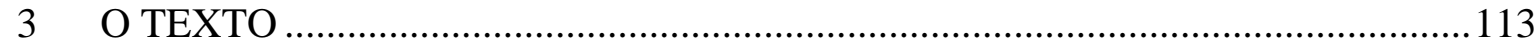

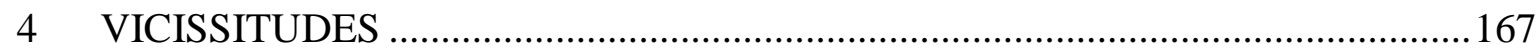

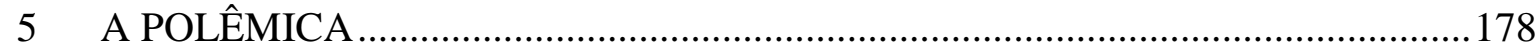

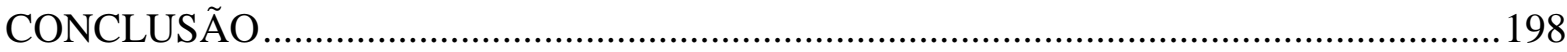

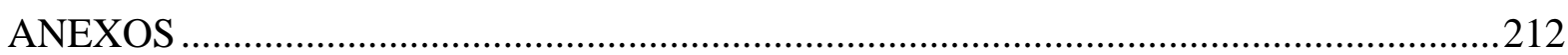

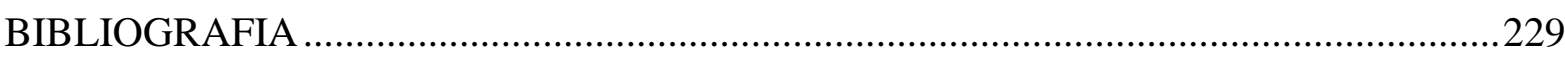




\section{ÍNDICE DOS ANEXOS}

ANEXO I - RUA DIREITA - GRAVURA DE JOÃO MAURÍCIO RUGENDAS ............212

ANEXO II - RESUMO DA HISTÓRIA DO BRASIL DE BELLEGARD ..........................213

ANEXO III - IMPERIAL COLÉGIO DE PEDRO II........................................................218

ANEXO IV - QUADRO COMPARATIVO DA DISTRIBUIÇÃO DAS NOTAS ENTRE A PRIMEIRA EDIÇÃO (EM DOIS VOLUMES) E A SEGUNDA EDIÇÃO (EM UM

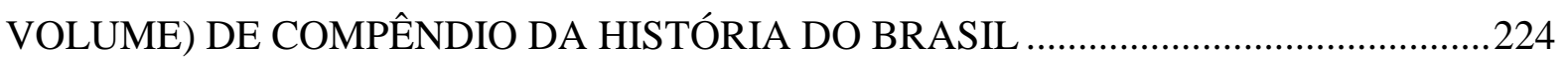

ANEXO V - DOCUMENTOS EM APENSO À PRIMEIRA EDIÇÃO .............................225 


\section{RESUMO}

Ao pôr em plano destacado uma obra e seu autor - o Compêndio da História do Brasil, de José Inácio de Abreu e Lima, publicado em 1843 -, o trabalho objetiva compreender como uma deliberação consciente visando a determinado fim - emancipar -, que orientou toda uma vida, atualizava-se nas páginas de um livro oferecido em especial à "mocidade Brasileira" como uma espécie de espelho no qual ela pudesse se reconhecer, e, assim, situava-se entre outros discursos e práticas destinados a formar os brasileiros, no movimento de expansão para dentro que individualiza a experiência imperial brasileira, em meados do século XIX. O trabalho objetiva também demonstrar que, embora as páginas de um compêndio não contenham o "resumo do mais substancial" de uma vida, elas propiciaram novos embates e polêmicas entre tantos outros travados por aquele que, ainda que reconhecido como um dos principais defensores da solução monárquica para o Brasil, não encontrava lugar na ordem imperial que se afirmava.

\section{PALAVRAS-CHAVE}

Compêndio da História do Brasil - Abreu e Lima - Expansão para dentro Historiografia - Brasileiros 


\begin{abstract}
José Inácio de Abreu e Lima published in 1843 his Compêndio da História do Brasil (Handbook of Brazilian History). This doctoral thesis aims to study this book and its author. On the one hand, its objective is to understand how a conscientious deliberation in order to achieve a very precise goal - emancipation -, a guide line to the whole life of Abreu e Lima, found its expression on this book, specially offered to the "Brazilian youth" as a kind of a mirror in which the youngsters could recognize themselves. Doing so, the book found its place among other discourses and practices which function was to shape the Brazilians, and became a part of the process of inland expansion (expansão para dentro) that was a main feature of the Brazilian Empire during the first half of the $19^{\text {th }}$ century. On the other hand, this doctoral thesis intends to demonstrate that, although the pages of a handbook do not express "the most substantial summary" of the biography of their author, they can certainly provide subjects for new debates and controversies among so many others sustained by Abreu e Lima, who was recognized as one of the main supporters of the monarchist solution to Brazil but never found his place on the Imperial State.
\end{abstract}

\title{
KEY WORDS
}

Compêndio da História do Brasil - Abreu e Lima - Inland Expansion Historiography - Brazilians 


\section{INTRODUÇÃO}

Este trabalho tem por objeto um livro - Compêndio da História do Brasil. E porque um livro pressupõe um autor e prováveis leitores, este trabalho tem por objeto também o autor do livro (e de inúmeros outros textos, manuscritos e impressos) e seus leitores (alguns conhecidos; outros, nem tanto). O autor é o pernambucano José Inácio de Abreu e Lima, militar, professor de matemática, editor e redator de pasquins, autor de livros; mas também exilado político, combatente nas guerras de libertação das colônias espanholas da América ao lado de Simón Bolívar, polemista aguerrido; e ainda defensor intransigente da alternativa monárquica para o Brasil, não hesitando em associar suas proposições políticas à figura do primeiro imperador, razão por que em não poucas oportunidades foi identificado como um “caramuru", após seu retorno ao Império do Brasil em 1832. Os leitores, a "mocidade Brasileira", a quem Compêndio era dirigido. Mas não apenas ela: em um momento em que os livros de História, ainda que não apenas eles, passaram a ter um elevado valor simbólico na identificação da nova nação e passaram a ser elemento que conferia prestígio, a lista dos subscritores da primeira edição do livro de Abreu e Lima revela os nomes de inúmeros leitores (e de umas poucas leitoras) da boa sociedade imperial; a eles se juntavam, de modo inevitável, os membros do Instituto Histórico e Geográfico do Brasil, dentre os quais o cônego Januário da Cunha Barbosa, Joaquim Manuel de Macedo e Francisco Adolfo de Varnhagen.

Em uma espécie de desdobramento que não quis evitar, este trabalho tem ainda por objeto os editores de um livro que, no intervalo de quatro décadas, alcançou cinco edições, sendo que as duas primeiras em 1843, o ano de seu lançamento. Por elas foram responsáveis os irmãos Laemmert, uns dos mais prestigiosos livreiros e editores na cidade do Rio de Janeiro, no momento em que a navegação a vapor possibilitava que a produção editorial da capital do Império do Brasil, plena ela também de imagens, símbolos e valores que exaltavam a Monarquia constitucional e unitária, chegasse com rapidez às províncias do "Norte" e do "Sul" do Império. 
Mas este trabalho não se define apenas nem principalmente por seu objeto (ou objetos). E sim por buscar respostas para algumas questões que me foram suscitadas pela vida, particularmente em sua dimensão acadêmica, desde a finalização de uma dissertação de Mestrado sobre as Lições de História do Brasil de Joaquim Manuel de Macedo. Se o fato da presença destacada de uma obra e seu autor nas duas oportunidades insinua semelhanças entre reflexões separadas por alguns anos, semelhanças essas traduzidas muitas vezes nas conversas com colegas e amigos por meio de uma indagação que só variava quanto ao personagem “Por que Macedo?'; “Por que Abreu e Lima?”-, cabe sublinhar nesta Introdução que aquelas reflexões se diferenciam acentuadamente, razão por que a resposta que procura(va) sublinhar essa diferença geralmente inicia(va)-se por uma observação tão trivial quanto elucidativa: porque muda a vida, mudam as questões. Novos problemas, novos objetos e novas abordagens - utilizando uma formulação já não tão nova - revelam, por certo, as mudanças na vida, não apenas no plano historiográfico. As razões que me levaram ao Compêndio de Abreu e Lima já não eram as razões que me tinham feito tentar compreender as Lições de Macedo.

Apresentavam-se, de um lado, as inúmeras vidas de Abreu e Lima. Às inúmeras vidas vividas por aquele que ficou também conhecido como o "General de Bolívar", em seus 75 anos de existência, somam-se aquelas inúmeras outras inventadas e reinventadas sem cessar por biógrafos, memorialistas e mesmo historiadores, ainda nos dias de hoje. E, de outro, a passagem de uma experiência imperial a outra - a passagem do "novo Império" fundado pelo Príncipe-Regente D. João desde a instalação da Corte portuguesa no Rio de Janeiro em 1808, no fundamental mera continuação do "antigo" Império português, ao Império do Brasil, surgido com a emancipação política de 1822 -; uma passagem que, assinalada por continuidades e descontinuidades, sobretudo, conduziu a uma experiência imperial ímpar, revelada, entre outros aspectos, em uma expansão para dentro.

Assim, este trabalho tem por objetivo compreender como o cruzamento destas duas dimensões - a de uma vida orientada por uma deliberação consciente visando a determinado fim: emancipar; e a de um Império que se distinguia pela impossibilidade do exercício de uma dominação ilimitada, em termos espaciais, temporais e ideológicos, característica das demais experiências imperiais - expressou-se nas páginas de Compêndio, cujo autor tinha como uma 
de suas intenções principais formar os brasileiros, no momento em que o movimento de expansão para dentro que individualizava a experiência imperial brasileira era caracterizado principalmente por discursos e práticas com a finalidade de expandir a Civilização, possibilitando assim aos que constituíam a Nação brasileira tanto reivindicar um lugar no conjunto das "Nações civilizadas" quanto conviver com outras "nações", africanas e "de cor", no território do Império do Brasil.

Mas um entrecruzar que não implica em afirmar, antes pelo contrário, que o livro de Abreu e Lima contém o "resumo do mais substancial" de uma vida. Todavia, os textos que preenchem suas páginas, profundamente marcados em algumas oportunidades por uma rememoração que parece não objetivar a conservação do passado e sim conter um apelo à felicidade do presente, propiciariam novos embates e polêmicas entre tantos outros travados por aquele que, ainda que reconhecido como um dos principais defensores da solução monárquica para o Brasil, ontem como hoje, parecia não encontrar lugar na ordem imperial que então se consolidava.

No capitulo I - Nem Dom Quixote nem Sancho Pança - recupero os aspectos mais significativos da vida (ou das vidas) de Abreu e Lima até a publicação de Compêndio em 1843, a partir dos propósitos que tenho em vista. Sirvo-me para tanto das biografias e memórias escritas a respeito do "filho do Padre Roma"; sirvo-me, sobretudo, dos seus próprios escritos e dos contemporâneos que com ele dialogaram, quase sempre de modo áspero, como foi o caso de Evaristo da Veiga. Combatente exímio com sua espada ao lado de Bolívar, Abreu e Lima esgrimia a pena com a mesma competência em defesa de uma deliberação consciente que orientaria toda a sua vida, visando sempre uma emancipação - de homens, de cidadãos e de jovens nações. Textos manuscritos, opúsculos, livros e artigos de jornais, como os de Torre de Babel, Arca de Noé e Raio de Júpiter, revelam reiteradamente suas opiniões e posicionamentos políticos a respeito de temas candentes de um tempo caracterizado pela "Era das revoluções" e pela "Era da abolição". Mas opiniões e posicionamentos que não deixavam de revelar de modo intenso o lugar singular que ocupava na interseção de três grandes experiências vitais, as quais tentei delimitar recorrendo a três pares de expressões: o Exílio e a Pátria; a identidade pernambucana e a identidade brasileira; e o projeto de um "novo império" e a emancipação do Império do Brasil. Tendo na lembrança e 
no exemplo de Simon Bolívar "um companheiro inseparável” desde o seu retorno ao Brasil, Abreu e Lima procurava compreender e influir nos rumos do Império no momento em que a atividade política refluía da Rua para o âmbito do Estado, caracterizando o triunfo da Ordem desenhada pelos saquaremas e o aprofundamento dos discursos e práticas civilizatórios voltados para a boa sociedade. O recurso à produção historiográfica recente me permitiu compreender, no novo momento de uma avassaladora expansão para dentro, por que estar no IHGB por meio de um compêndio era, no entender de Abreu e Lima, o modo mais eficaz de emancipar e constituir os brasileiros, no transcurso de uma já longa trajetória.

No capítulo II - Um Compêndio da História do Brasil - abro o Compêndio. Ao fazêlo tenho a possibilidade de resgatar todo um jogo de intenções. Em primeiro lugar, as do próprio autor ao se decidir por "formar um compêndio" e a respeito do modo como realizá-lo. Em seguida, de modo até certo ponto surpreendente, as intenções dos irmãos Laemmert, os editores que ao realizarem uma segunda edição da obra no mesmo ano do seu lançamento, em único tomo, ao passo que a primeira era em dois tomos, suprimindo um grande número de notas e excluindo todos os documentos em apenso, sublinhavam fortemente a diferença entre um compêndio em seu significado original - "resumo do mais substancial...de alguma arte, ciência ou preceitos" (o único significado registrado por Moraes e Silva na 2a . edição de seu Dicionário) - e um compêndio que corresponde, por derivação metonímica, a um livro ou manual escolar, o que, ao cabo, possibilita melhor compreender a história dos manuais escolares oferecidos à leitura dos estudantes no Império do Brasil. E, por fim, as intenções dos membros do IHGB, em particular a de seu Secretário perpétuo, o cônego Januário da Cunha Barbosa, as quais colocam em destaque as diferenças entre "formar um compêndio" e "escrever a História do Brasil”, bastando lembrar que o ano da edição de Compêndio é o mesmo da premiação pelo Instituto da Memória de von Martius sobre como se devia escrever a História do Brasil. A opção por esta, ou seja, pela escrita da História do Brasil, abriria caminho à acirrada polêmica travada entre Abreu e Lima e Varnhagen, a primeira da historiografia brasileira. Ao colocar em evidência o "Texto" de Compêndio, a polêmica me permitiu recuperar tanto o papel atribuído por Abreu e Lima à atividade mercantil quer no estabelecimento de uma filiação da formação brasileira à experiência histórica européia, cristã e civilizada, quer na ocupação e civilização do "sertão", quanto o significado atribuído a brasileiro, a identidade que então se forjava, por ambos os autores. Referidos ambos os 
pontos à existência de um território unificado e contíguo - o território do Império -, eles possibilitam compreender como o território, considerado a partir de um ponto de vista anacrônico, é o critério que preside a escolha dos acontecimentos que devem constituir uma narrativa - a História do Brasil -, assim como atribuir aos que o habitam, desde sempre, a condição de brasileiros: os "habitantes naturais do Brasil", primeiro, e a população gerada pela colonização, depois. Se Varnhagen não tende a se afastar de Abreu e Lima no que se refere ao primeiro ponto, sua discordância em relação ao segundo é contundente. Foi a polêmica que me permitiu, ainda, vincular aquelas posições irredutíveis aos critérios distintos de verdade que orientavam os interlocutores, Abreu e Lima justificando o estilo que distinguia sua obra e os textos que escolhera "compilar" por meio da referência à autoridade de seus autores, em uma íntima adesão aos critérios antigos ou clássicos, enquanto para Varnhagen a verdade que distinguia um texto historiográfico decorria da noção de prova, intimamente associada ao método crítico que caracterizava uma concepção moderna de História. Ela me permitiu, por fim, relembrar a dupla interdição imposta a uma obra: a primeira por ocasião da avaliação pelo IHGB em 1844; a segunda, salvo raras exceções, pelo esquecimento ou simples referências, mesmo por aqueles que exaltam a figura de Abreu e Lima em outros planos.

Na Conclusão, após fazer Abreu e Lima retornar para Pernambuco e dali partir para um último exílio, após uma última polêmica, procuro recuperar, de modo extremamente resumido, as outras vidas que o autor de Compêndio continua a viver nos escritos e na imaginação de seus compatriotas, alimentando sonhos e projetos também referidos a uma mesma deliberação consciente - emancipar. 


\section{NEM DOM QUIXOTE NEM SANCHO PANÇA}

José Inácio de Abreu e Lima viveu várias vidas em seus 75 anos de existência. Tantas e tão diversas experiências entre 1794 e 1869 que quase não seria um despropósito imaginar que houve vários abreus e limas. Ele foi o aluno da Real Academia Militar e o filho do Padre Roma; o combatente pela independência das colônias espanholas na América e o "General de Bolívar"; o jornalista ardoroso e polêmico no Rio de Janeiro e no Recife; o autor de Bosquejos históricos, de Resumen histórico de la última dictadura del libertador Simón Bolívar, de O Socialismo e de Compêndio da História do Brasil; o prisioneiro político, o exilado e o adepto do ex-imperador Dom Pedro I; o sócio do IHGB e o protagonista junto com Varnhagen da primeira polêmica historiográfica assistida pela instituição. Enfim, foi militar, professor de matemática, jornalista, editor de pasquins e autor de livros.

Inúmeras vidas e variadas experiências. Todas, porém, referidas a um mesmo projeto, a uma deliberação consciente, implicando escolhas e recusas. Experiências múltiplas, que não prescindiam de uma conduta organizada visando a determinados fins. ${ }^{1}$ Em seu caso, emancipar. A deliberação consciente de se emancipar, assim como a outros homens e mulheres; e, em um mesmo movimento, empreender ou concorrer para uma, para várias constituições: a de novos sujeitos políticos e a de outras identidades - os cidadãos; o povo; os brasileiros. Um só projeto, uma única vida, um único Abreu e Lima.

\section{MOLDURAS}

Como toda e qualquer outra, uma vida que entrecruza com outras vidas, em determinadas circunstâncias e em momentos diversos. Um entrecruzamento que favorece

\footnotetext{
${ }^{1}$ Sobre a noção de projeto, cf. Gilberto Velho (1994).
} 
aproximações e provoca distanciamentos; propicia a construção de individuações; gesta imagens e representações a respeito de si e dos outros, assim como pelos outros a seu respeito, pondo em destaque quer a plasticidade das identidades em elaboração e reelaboração pelos próprios sujeitos, quer a relação entre a identidade e o discurso, no sentido de que ambos objetivam convencer alguém a respeito de algo, porque as identidades também não são senão "uma construção que se narra" (CANCLINI, 2001). Mas um entrecruzamento que conduz, ainda, a que se lide inevitavelmente com heranças na construção de algo novo. Assim, Abreu e Lima combateu não apenas ao lado de Simón Bolívar para emancipar os povos do colonialismo espanhol, entre 1818 e 1830, mas também no Recife contra o Monsenhor Joaquim Pinto de Campos em defesa do casamento civil, visando emancipar homens e mulheres da tutela do clero, já ao final de sua vida. Por entender que a única maneira de impedir a fragmentação do Império do Brasil, emancipando-o da "ameaça da anarquia" que, no seu entender e de muitos outros, resultara da Abdicação de Dom Pedro I, empenhou-se com ardor na recuperação da figura e do papel do ex-imperador, quando regressou ao país, em 1832, em momento de pleno "triunfo" do "princípio democrático" (ROCHA, 1956). Por sua atuação nas guerras de independência da América hispânica poderia ter recebido de alguém o epíteto de "o emancipador"; para outros era apenas o "general das massas". Ao morrer, foi enterrado no Cemitério dos Ingleses, porque alguns julgavam não ser digno de sepultamento em campo católico.

Das experiências vividas por Abreu e Lima, a do exílio se constituiu, sem dúvida, em uma das mais marcantes. Aos sucessos vividos ao lado de Bolívar, que lhe permitiam experimentar fortemente seu projeto emancipacionista, somavam-se certamente a amargura cotidiana, a distância e a lembrança de sua terra - a saudade, enfim. Uma amargura alimentada pelas notícias chegadas da América portuguesa, pelos mais diversos meios, dentre os quais, em determinado momento, o mais significativo teria sido o Correio Braziliense, o jornal - um verdadeiro “Armazém literário” - que Hipólito José da Costa editava em Londres. Notícias que davam conta de uma experiência incomum, a da permanência de uma Corte européia na América, a qual se desdobraria, de modo em princípio inimaginado, em uma outra emancipação. Notícias que colocavam o "Brasil" e a "Corte" quase sempre em posição de destaque em relação ao seu "Pernambuco", porque aquela era a experiência da 
passagem de um império a outro: do "novo império"2 - que a Corte portuguesa procurara criar por ocasião de sua transferência para o Rio de Janeiro - ao Império do Brasil fundado por Dom Pedro I; algo ímpar na experiência emancipacionista do conjunto das colônias americanas, mas vivida e compreendida de diferentes maneiras pelos contemporâneos, dentre os quais se situava o exilado Abreu e Lima.

Minha prática profissional levou-me ao Compêndio; dele, a seu autor; e daí, de modo quase inevitável, a seus inúmeros biógrafos. No decorrer de uma trajetória de pesquisa em que inúmeros outros escritos de Abreu e Lima me foram apresentados, os quais eram expressões sempre vibrantes de um mesmo projeto, algo foi se esboçando aos poucos, acabando por se tornar um pressuposto incontornável: a compreensão da participação de Abreu e Lima em acontecimentos cruciais implica a consideração do seu lugar ${ }^{3}$ na interseção de três grandes experiências vitais. Tento delimitar essas experiências vitais recorrendo a três pares de expressões - o Exílio e a Pátria; a identidade pernambucana e a identidade brasileira; e o projeto de um "novo império" e a emancipação do Império do Brasil. Elas talvez possibilitem melhor conhecer, compreender e até mesmo sentir o lugar no qual se desenrola uma trajetória singular, lugar que é, ele próprio, um fator constituinte; um lugar que seu protagonista principal não quis ou não soube evitar, por ser, em larga medida, fruto de uma prévia deliberação consciente; mas também um lugar onde o pensar ao se desdobrar não apenas no agir, mas inevitavelmente também no sentir, revela os diferentes constrangimentos impostos por uma determinada sociedade àqueles que a compõem, assim como "as margens de liberdade" ${ }^{4}$ que se apresentam a cada qual, recorrentemente visitadas e forçadas por Abreu e Lima. Um lugar ainda que orientaria, em não poucas oportunidades, as percepções, avaliações e comportamentos dos contemporâneos, quer dos que concordavam ou apoiavam o proceder de Abreu e Lima quer daqueles que dele discordavam e o combatiam, e daí transbordariam para os textos biográficos e historiográficos.

\footnotetext{
${ }^{2}$ O "novo império" que a Corte portuguesa pretendeu criar ao se estabelecer no Rio de Janeiro tem sido denominado "império luso-americano" ou "império luso-brasileiro" por parte significativa da atual historiografia, brasileira e portuguesa. Por razões que serão explicitadas adiante, evito aqui tal denominação.

${ }^{3}$ Recorro aqui, em parte, às proposições do geógrafo Yi-Fu Tuan a respeito do conceito de "lugar" no texto “Geografia humanística” (CHRISTOFOLETTI, 1985). A respeito, cf. também Armand Fremont (1980).

4 “A questão é, portanto, como definir as margens - por mais estreitas que possam ser - da liberdade garantida a um indivíduo pelas brechas e contradições dos sistemas normativos que o governam. Em outras palavras, uma investigação da extensão e da natureza da vontade livre dentro da estrutura geral da sociedade" (LEVI, 1992).
} 
Na tentativa de compreender este lugar, e melhor traçar não só as molduras mas também as margens de liberdade, retorno àquelas experiências, começando pela terceira delas.

\subsection{Uma expansão para dentro}

Como é sabido, a instalação da Corte portuguesa no Rio de Janeiro, em 1808, representou para uma parcela significativa da elite letrada portuguesa a possibilidade de concretização efetiva de um projeto, cujos contornos foram sendo delineados à medida que declinava o velho Reino: a fundação de um "novo império". 5 Em fins do século anterior, em uma Memória que redigira a respeito dos melhoramentos a serem realizados nos domínios de Portugal na América, Dom Rodrigo de Sousa Coutinho já sustentava ser necessário

"criar um poderoso império no Brasil, donde se volte a reconquistar o que se possa ter perdido na Europa".

Em 1808, já no Rio de Janeiro, anunciava-o o Manifesto de $1^{\circ}$ de maio, apregoando ao mundo que

"a Corte de Portugal levantará a sua voz do seio do novo império que vai criar".

Desde Londres, Hipólito José da Costa incentivava o empreendimento, ao sustentar no número inaugural do Correio Braziliense que

[...] o Príncipe do Brasil, que, por parte de Sua Mulher, é o único herdeiro legítimo da Monarquia espanhola, deve apossar-se de tudo o que lhe ficar ao capto, antes que o inimigo comum tome medidas convenientes, para se afirmar por tal maneira, no trono de Espanha, que até as Colônias lhe não

\footnotetext{
${ }^{5}$ Em toda esta parte sigo, de perto, as proposições de Ilmar Rohloff de Mattos (2004, p. 727-736; 2005, p. 271300; 2003a). "Construtores e herdeiros. A trama de interesses na construção da unidade política", in István Jancsó (Org.) Independência: história e historiografia. São Paulo: Hucitec: Fapesp, 2005, p. 271-300; e O tempo saquarema. A formação do estado imperial. 5a . Edição. São Paulo: Hucitec, 2003.
} 
escapem. [...] Não entrarei aqui na discussão dos limites que deve ter o Império do Brasil, e até que ponto o Príncipe Regente poderia com prudência usar os direitos que tem ao todo das Colônias da Espanha.

Não obstante as vicissitudes da "Era das revoluções" (HOBSBAWM, 1977), a "Monarquia" portuguesa - que se apresentava, então, como um "novo império" - conseguia manter "estados [...] espalhados pelas cinco partes do mundo", no dizer de Silvestre Pinheiro Ferreira, em 1815. O conselheiro régio enumerava aqueles "estados" - o Império do Brasil; o Reino de Portugal, incluindo as ilhas atlânticas; os Domínios da África; e aqueles da Ásia como oportunidade para melhor sublinhar a importância do "Império do Brasil", e assim obter a aquiescência régia à sua proposta de elevação do "Império do Brasil" à categoria de Reino Unido a Portugal e Algarves. Dos argumentos de Silvestre Pinheiro resultava, inevitavelmente, a constatação de que naquela parte - o "Império do Brasil" - do todo - a "Monarquia" portuguesa - a região Centro-Sul ia ganhando importância cada vez maior, por ser polarizada pela presença da Corte portuguesa no Rio de Janeiro.

Todavia, ainda que rotulado como um "novo império", era a velha Monarquia que continuava existindo e se buscava preservar. Não por outra razão, o "novo império" permanecia referido a uma concepção clássica de império, a qual continuava sendo conformada

por uma concepção dinástica, propiciadora e legitimadora a um só tempo de uma organização hegemônica que transcendia os grupos étnicos ou políticos naturais, não necessariamente contínuos no espaço. E tinha o seu sentido definido por uma tendência para um certo tipo de dominação universal, pela pretensão a um domínio ilimitado em três dimensões: espacial, temporal e ideológica. Conformação e sentido presentes tanto nos argumentos de natureza dinástica expostos por Hipólito José da Costa para defender os direitos dos Braganças sobre as colônias espanholas na América quanto na decisão da Corte instalada no Rio de Janeiro de ocupar a Guiana Francesa e a Banda Oriental do Uruguai. (MATTOS, 2004, p. 731). 
Neste "novo império", conforme disse acima, ganhava relevo um "estado": o "Império do Brasil". Um nome que identificava um vasto território unificado e contíguo, não obstante a constituição regional e dispersa gerada pela colonização portuguesa. Um território cujo contorno fora delineado pelo Tratado de Madri de 1750, cuja monumentalização não tardaria a se esboçar.

Os acontecimentos dos anos de 1821 e 1822 transformaram essa parte da "Monarquia" portuguesa - a qual recebia, entre outras denominações, a de "Império do Brasil" - em um corpo político autônomo - o Império do Brasil. Aqueles que empreenderam a emancipação política optaram por conservar um nome - Império do Brasil; empenhar-se-iam, naqueles anos e nos seguintes, por preservar o que passaram a apresentar como uma das principais heranças da colonização portuguesa - um vasto território unificado e contíguo; e passaram a denominar brasileiros a todos aqueles que associavam suas vidas ao novo corpo político, ao mesmo tempo em que por ele eram conformados, pois conforme enunciara José Bonifácio de Andrada e Silva, em 1823,

"brasileiro é para mim todo o homem que segue a nossa causa, todo o que jurou a nossa independência". ${ }^{6}$

O tempo preenchido pelos acontecimentos do Primeiro Reinado (1822-1831) e da fase inicial das Regências (1831-1836), e nos quais se destaca o acontecimento crucial da Abdicação de Dom Pedro I (7 de abril de 1831), foi representado por Justiniano José da Rocha (1956) como o momento da "Ação", em suas fases de "luta" (1822-1831) e "triunfo" (1831-1836). No momento que Justiniano José da Rocha caracterizou como animado pelo "princípio da liberdade ou princípio democrático", as acirradas disputas entre as facções político-partidárias, expressões de projetos divergentes, ao lado das recorrentes revoltas, rebeliões e insurreições, não foram suficientes para alterar um nome, fragmentar um território e abolir a forma monárquica; em seu decorrer, porém, o poder do Império britânico pôs fim às possíveis pretensões de domínio ilimitado do novo Império do Brasil, ao menos em termos

\footnotetext{
${ }^{6}$ Anais da Assembléia Constituinte do Império do Brasil (1972, t. 3, p. 88. Sessão de 15 de julho de 1823. Edição fotocopiada da edição de 1876). Cf., ainda, Ilmar Rohloff de Mattos (2005).
} 
espaciais, ao expulsá-lo do continente africano, por meio dos tratados de reconhecimento da independência do Império do Brasil que frustrava o plano de tornar Angola independente do Reino de Portugal, incorporando aquela região africana ao Império do Brasil.

Durante os tempos da "Ação", em especial a partir dos acontecimentos que conduziram à abdicação do primeiro imperador, a concepção clássica de império foi sendo contestada por uma outra concepção de império, e acabaria por lhe ceder o lugar. Esta era tributária, por certo, da fragmentação dos antigos impérios e da emergência dos estados nacionais, processos que se expressavam na crise dos reinos dinásticos, ao mesmo tempo que desta eram expressões; mas era tributária sobretudo das experiências vividas pelos brasileiros em seu duplo movimento de emancipação e constituição. A esse respeito, à concepção de império que passava a fundar o Império do Brasil não eram estranhas tanto as heranças de um nome e de um território quanto a impossibilidade de um poder ilimitado, em termos espaciais; mas ela era conformada sobretudo por uma associação original e singular entre as concepções de Império, Estado e Nação.

Ora, esses modos original e singular de associar "Império do Brasil", "Estado imperial" e "Nação brasileira" decorriam do fato de o Império do Brasil somente poder conter um único Estado, o qual, por sua vez, pressupunha um território já praticamente definido em sua extensão, o qual deveria ser representado como nacional. Mas essas singularidade e originalidade decorriam também da vontade de associar o Império do Brasil a uma única nação - a Nação brasileira. Uma associação revelada plenamente pelo texto constitucional de 1824 ao definir que

"são cidadãos brasileiros os que no Brasil tiverem nascido, quer sejam ingênuos ou libertos, ainda que o pai seja estrangeiro, uma vez que este não resida por serviço de sua Nação".

Ao associar íntima e fortemente nascer e nação, o artigo da Carta outorgada recuperava de um modo particular a origem etimológica comum de ambas as palavras: nascer vem de nascor; do mesmo verbo latino deriva natio, onis, que dá origem a nação na língua 
portuguesa. Desde a emancipação de 1822, nascer era passar a pertencer a um corpo político e a uma nação, os quais também estavam nascendo - ou seja, sendo constituídos. A experiência do Império do Brasil não era diferente de outras experiências históricas contemporâneas. Aqui também o surgimento de um Estado-nação fazia do nascimento ou da natividade o alicerce de sua soberania; e ele exigia adesão inequívoca e fidelidade exclusiva daqueles que o compunham, somente permitindo ou tolerando outras identidades caso elas não colidissem com a irrestrita prioridade da lealdade nacional. Mas, ao mesmo tempo, a uma associação que era historicamente construída buscava-se dar a aparência de algo natural (AGAMBEN apud BAUMAN, 2005, p. 25). Se os novos cidadãos do novo Império do Brasil já não eram "portugueses americanos", não deixavam de ser "pernambucanos”, “bahienses”, "paulistas" ou "mineiros"; todavia, não deviam ignorar que, desde então, eram acima de tudo brasileiros. As identidades locais e regionais forjadas durante os trezentos anos da colonização portuguesa eram deslocadas em proveito de uma nova identidade, a ela articulando-se e subordinando-se, como frações de uma mesma unidade; o lugar de nascimento antes referido a uma localidade próxima e a uma familiaridade mútua, deslocavase para um outro espaço, incomensuravelmente mais amplo e imaginado - a nação (ou a pátria ampliada, como durante algum tempo foi mais comum imaginar).

A relação entre nascer e pertencer à nação pressupunha um território. A este território denominava-se Império do Brasil. Essa é a razão por que ao comentar a Constituição Política do Império do Brasil, José Antônio Pimenta Bueno (1978, p. 21), marquês de São Vicente, diria ser o território "a mais valiosa propriedade" do Império.

De modo complementar, a relação nascimento-pertencimento à nação, mediada pelo território, permitia identificar aqueles que eram estranhos ao novo corpo político e à nova nação. Assim, não eram brasileiros os escravos e os "portugueses europeus" que habitavam o território do Império do Brasil no momento da independência. Aos "portugueses europeus" abria-se a possibilidade de se tornarem brasileiros caso aderissem à independência, "expressa ou tacitamente, pela continuação de sua residência", de acordo com o mesmo artigo constitucional. Mas o mesmo não deveria ocorrer com os escravos, em decorrência de seu estatuto jurídico. Caso se tornassem libertos, somente os nascidos no território do império se tornavam cidadãos brasileiros, podendo ser votantes (eleitores de primeiro grau), mas não 
poderiam ser eleitores de segundo grau. Uma ambigüidade que se estendia aos exilados da antiga colônia americana de Portugal, como era o caso de Abreu e Lima, que por aquela época acompanhava com vivo interesse os acontecimentos relacionados à emancipação por meio muitas vezes dos relatos dos que foram forçados ao exílio em decorrência daqueles acontecimentos ou das notícias publicadas nos jornais que circulavam pelo território americano.

Assim, a emancipação política se desdobrava inevitavelmente em inúmeras e distintas constituições, empreendidas em tempos e ritmos diferenciados: de um lado, a constituição de um corpo político - o Estado imperial - e a de seus constituintes - os cidadãos brasileiros, também súditos do imperador; de outro, a de uma nação - a Nação brasileira - e a de seus membros - os brasileiros.

Mas constituições que ocorriam em uma sociedade cujo traço definidor mais significativo transparecia de modo iniludível no mesmo artigo do texto legal de 1824 - "quer sejam ingênuos ou libertos" - isto é, uma sociedade de base escravista, que herdara da experiência colonizadora a convivência forçada de três grupos étnicos. Nela, as diferenças e hierarquizações construídas a partir dos atributos primários de liberdade e propriedade (especialmente a propriedade de escravos), matizados por critérios raciais e culturais, distinguiam a boa sociedade - isto é, aqueles que eram livres, proprietários de escravos e se representavam como brancos -; a plebe - ou seja, aqueles que eram livres, não eram proprietários de escravos e eram representados nem como brancos nem como negros -; e os escravos - isto é, aqueles que eram propriedades de outrem e não eram brancos; diferenças e hierarquizações que, ao cabo, punham em questão o conceito moderno de nação (MATTOS, 2003).

Ora, a opção dos homens e mulheres brasileiros pela manutenção da escravidão era uma opção que implicava na convivência da Nação brasileira - isto é, dos brasileiros - com outras "nações" no território do Estado imperial. Conforme observou com agudeza Mary Karasch (2000), no Rio de Janeiro imperial era utilizado com freqüência o termo "nação" para identificar os escravos negros e ameríndios, embora não se deixasse de discriminar entre as "nações de cor" - os escravos nascidos no Brasil - e as "nações africanas". E tal 
observação me possibilita compreender como a utilização do termo "nação" para os contingentes escravizados permitia aos brasileiros melhor identificar a "sua nação", isto é, a Nação brasileira, assim como os atributos que distinguiam os brasileiros, dentre os quais assumia destaque o pertencimento ao conjunto das "Nações civilizadas" (MATTOS, 2003).

Revela-se, assim, como se ampliara a noção de brasileiro entre o momento da independência política e o da consolidação da ordem imperial em meados do século.

Naquele primeiro momento, como já destacado, brasileiro $^{7}$ identificava, sobretudo, "todo o homem que segue a nossa causa, todo o que jurou a nossa independência", conforme enunciara José Bonifácio de Andrada e Silva no calor da "Guerra de Independência" e Jean Baptiste Debret retratara, a pedido e sugestão do mesmo Andrada, no pano de boca do teatro onde se dera a comemoração da coroação de D. Pedro I (DEBRET, 1965, p. 274). Elementos persuasivos e coercitivos combinavam-se para a expansão de uma "causa", embora tenha sido por meio da força militar, sobretudo, que o projeto de independência urdido no Rio de Janeiro se impôs. Assim, partindo do Rio de Janeiro, as tropas formadas ou contratadas pelo governo imperial estenderam pela força aquele projeto às províncias que ainda se mantinham fiéis às Cortes de Lisboa, no mesmo movimento que subordinavam os interesses provinciais à política imperial, razão por que o triunfo daquelas forças militares - o triunfo da "Independência do Brasil" - foi vivido em muitas das províncias como a perda ou restrição da liberdade, quer, sobretudo, pelos representantes locais da boa sociedade, quer por elementos da plebe ou do "povo mais ou menos miúdo", como foi o caso paradigmático da província de Pernambuco por ocasião da Confederação do Equador. ${ }^{8}$

\footnotetext{
${ }^{7}$ Acredito ser desnecessário recordar aqui as significações anteriores de "brasileiro" - o traficante de pau-brasil, no século XVI, e o português que tendo enriquecido no Brasil retornava à terra de origem, já no final do século XVIII -, as quais tenderam a cair em desuso desde então.

${ }^{8}$ A esse respeito são ilustrativas as palavras de José da Natividade Saldanha, nas páginas do Argos Pernambucano, em 1824: "Antes ser livre e não ser independente, do que ser independente e não ser livre. E que vantagem tiraríamos nós de tal Independência? Não estarmos sujeitos ao Rei D. João VI e aos caprichos [do conde] de Subserra, [do] conde, hoje marquês, de Palmela, Salter de Mendonça e Gomes de Oliveira. Que ridícula vantagem! E não ficávamos sujeitos aos caprichos de Maciel da Costa, de Vilela Barbosa e de outros? Antes viver na escravidão de Portugal do que na do Brasil, para que se não diga que os brasileiros foram tão estúpidos que tendo forças para separar-se da metrópole e tendo ocasião de adotar um governo livre e acomodado às suas circunstâncias, adotaram um governo infame e vil como são todos os governos absolutos" (MELLO, 2004, p. 19).
} 
Diversa, porque ampliada, é a noção de brasileiro no momento de consolidação da ordem imperial. Ela transborda a causa política da emancipação política, espraiando-se no sentido de expressar não apenas uma identidade política, e sim uma identidade nacional: a nacionalidade brasileira. Um movimento que implica também a ampliação da noção de povo, que não mais se restringe ao sujeito político da emancipação, passando a conter em si um sentimento novo: o sentimento nacional. Brasileiro se tornava uma nacionalidade; a Nação brasileira continha o povo brasileiro. Mas um movimento de ampliação que não se dava natural e espontaneamente, resultando ele também de uma deliberação consciente, de políticas e práticas diversas que tinham como referência um determinado projeto político.

Assim, a consolidação da Ordem imperial pressupunha a difusão da Civilização, o que, então, era caracterizado por alguns como um "desenvolvimento moral e intelectual". E tal difusão punha em destaque tanto uma ação política quanto revelava o papel dos letrados na nova sociedade. Conforme destacara o romancista José de Alencar,

[...] sobretudo compreendem os críticos a missão dos poetas, escritores e artistas, nesse período especial e ambíguo de formação de uma nacionalidade. São estes os operários incumbidos de polir o talhe e as feições da individualidade que se vai esboçando no viver de um povo. (ALENCAR, 1965, p. 497).

O Império do Brasil não diferia dos demais Estados nacionais em constituição por essa mesma época. Nele também foi fundamental o papel de três grandes narrativas na construção da nação: uma literatura, uma história e uma língua nacionais, com seus propósitos “imperiais" (HALL, 2003). Todavia, se em outros Estados nacionais o objetivo era a constituição de um corpo homogêneo - a Nação moderna -, o que pressupunha a existência de homens e mulheres representados como livres e iguais juridicamente, no Império do Brasil em meados do século XIX não se objetivava a constituição desse "todo homogêneo", do que resultava tanto um distanciamento quer da experiência daqueles Estados quer das proposições 
de José Bonifácio à época da emancipação política, ${ }^{9}$ quanto a reiteração das distâncias sociais entre livres e escravos, entre o "mundo do governo" e o "mundo do trabalho", além da preservação dos pressupostos que reproduziam o "mundo da desordem". ${ }^{10} \mathrm{Um}$ acontecimento, dentre vários, revela com nitidez a opção política pela preservação daqueles “mundos". Em 1859, ou seja, nove anos após a extinção do tráfico intercontinental de escravos, José Antônio Pimenta Bueno, futuro marquês de São Vicente, argüia a respeito da atribuição de cidadania brasileira ao escravo liberto, nascido fora do Brasil, posicionando-se a favor. Submetida a questão ao Conselho de Estado, o parecer em contrário do relator, aprovado e acolhido pelo imperador D. Pedro II, sustentava, entre outros argumentos, que muitos libertos nessas condições haviam sido deportados para fora do Império, na Bahia e no Rio de Janeiro, o que tornava manifesto ainda uma vez que, na dúvida sobre a nacionalidade do liberto, o governo imperial preferia considerá-lo indesejável, expulsando-o do país (O CONSELHO..., 2005). Sublinhava-se assim, ainda desta vez, a originalidade e singularidade da experiência imperial brasileira, a qual propunha cotidianamente aos brasileiros uma espécie de jogo de comparação quer com os habitantes das "Nações civilizadas" - destacando semelhanças e diferenças, as quais em não poucas oportunidades desdobraram-se em um sentimento de superioridade -, quer com as demais "nações" que habitavam o mesmo território do Império; um jogo de comparações que tinha como veículos privilegiados aquelas diferentes narrativas.

Mas retorno a dez anos atrás. Em 1849, quando a derrota dos praieiros anunciava o triunfo da ordem imperial, inaugurando os anos que J. J. da Rocha identificou como sendo os de "Transação", passava a ser publicada na capital do Império do Brasil a revista Guanabara, sob a direção de Manuel Araújo Porto Alegre, Joaquim Manuel de Macedo e Antônio Gonçalves Dias. Na apresentação da revista, seus editores referiam-se à "época atual" entenda-se, aos sucessos de 1848 tanto na França quanto no Brasil - para destacar que

\footnotetext{
9 "É tempo de irmos acabando gradualmente até os últimos vestígios da escravidão entre nós, para que venhamos a formar em poucas gerações uma nação homogênea, sem o que nunca seremos verdadeiramente livres, respeitáveis e felizes. É da maior necessidade ir acabando tanta heterogeneidade física e civil; cuidemos pois desde já em combinar sabiamente tantos elementos discordes e contrários, em amalgamar tantos metais diversos para que saia um todo homogêneo e compacto que não se esfarele ao pequeno toque de qualquer nova convulsão política" (ANDRADA E SILVA, 1945).

${ }^{10}$ A respeito dos três mundos constitutivos da sociedade imperial, cf. Ilmar Rohloff de Mattos (2003).
} 
"convence os espíritos de que nada mais nos resta a experimentar, e que devemos concentrar todas as nossas forças para o desenvolvimento moral e intelectual, única base de um seguro e permanente progresso".

"Desenvolvimento moral e intelectual" possibilitado por uma publicação cujo conteúdo era

[...] dedicado ao recreio das famílias, à mocidade das escolas, ao comércio e às artes, algumas vezes não se tornará indigno do filósofo e dos estadistas; pois com a mistura de assuntos graves e obras amenas e variadas, procurará satisfazer da melhor maneira que for possível as curtas promessas que agora faz. (RICÚPERO, 2004, p. 99-100). ${ }^{11}$

Assim, a consolidação da Ordem e a difusão da Civilização sob a direção saquarema distinguiam-se por políticas e práticas que não se restringiam a um exercício de dominação das demais "nações" pelo Governo do Estado. Elas se distinguiam, sobretudo, pelo exercício cotidiano de uma direção intelectual e moral dos brasileiros, em especial daqueles responsáveis pelo Governo da Casa, ${ }^{12}$ o qual possibilitava a difusão de valores, signos e símbolos imperiais servindo-se de instrumentos diversos, como a instrução pública, a imprensa, uma política médica, as linhas de navegação a vapor que uniam as províncias à Corte... Políticas e práticas que revelavam que o Estado imperial empreendia uma expansão diferente, como resultado de uma combinação singular: a da impossibilidade de uma expansão territorial com a opção pela coexistência da Nação brasileira com outras "nações" no interior do território imperial. Uma expansão diferente, de modo permanente e constante, a partir do Rio de Janeiro, indo ao encontro dos brasileiros que constituía, de modo a inscrevê-los na Nação brasileira e na Ordem imperial. Uma expansão para dentro - eis o traço mais

\footnotetext{
${ }^{11}$ Diz o autor a respeito da revista: “[...] o projeto de direção saquarema, com a qual a revista Guanabara se identifica, pretende forjar, a partir do Rio de Janeiro, uma literatura que unifique as diferentes experiências e sensibilidades daqueles que tinham sido colonos lusitanos espalhados pela América" (RICÚPERO, 2004, p. 99100).

${ }^{12}$ Sobre as relações entre o Governo do Estado e o Governo da Casa na construção do Estado imperial brasileiro, cf. Ilmar Rohloff de Mattos (2003).
} 
significativo de uma originalidade e uma singularidade; uma expansão para dentro - eis o que diferencia o Império do Brasil de outras experiências imperiais.

Ora, é justamente este traço distintivo da experiência imperial brasileira - a expansão para dentro - que tomo como um ponto de partida. A partir dele, esforço-me por revisitar a diferenciada e emocionante trajetória de Abreu e Lima, procurando compreender como ela acabou por se projetar nas páginas de um compêndio.

\section{DE UM CERTO JOSÉ INÁCIO A ABREU E LIMA ${ }^{13}$}

\subsection{Dois josés}

Foi no dia 6 de abril de 1794, na vila do Recife, que nasceu José Inácio de Abreu e Lima. Recebia o nome de seu pai, embora este viesse a ser mais conhecido como o Padre Roma, alcunha que recebera por ter sido ordenado sacerdote na sede da Cristandade ocidental e conservara apesar de ter largado a batina para se casar.

No mesmo ano nasceu José Martiniano de Alencar, na capitania do Ceará, para onde sua família tinha migrado, vinda de Pernambuco, em fins do século anterior. ${ }^{14}$

Dois josés, cujas trajetórias de vida ora se aproximaram ora se afastaram, como expressões muitas vezes de experiências partilhadas. Ao primeiro dos josés dou posição de destaque; o segundo aparecerá sempre como um contraponto.

À época do nascimento de José Inácio já eram visíveis as transformações ocorridas na economia pernambucana decorrentes das medidas do período pombalino: “o avanço da

\footnotetext{
${ }^{13}$ À medida que realizava as primeiras leituras sobre a vida de Abreu e Lima pude constatar que um número significativo de informações era repetido pelos diversos autores dos dicionários biográficos, biografias e textos diversos consultados. Tal descoberta embasa a decisão de não assoberbar esse texto com referências longas e também repetitivas. Mesmo assim, escolhi inserir algumas delas, quer por se apresentarem centrais e potencialmente ricas, quer porque as pude comprovar por meio do confronto com outras fontes.

${ }^{14}$ Sobre José Martiniano de Alencar, cf., entre outros, M. Cavalcanti Proença (1965, p. 15-88).
} 
fronteira agrícola na mata sul, a consolidação de uma classe de pequenos proprietários rurais e o surto algodoeiro iniciado ao redor de 1780”. Na mata norte, mais povoada que a mata sul, conviviam a pequena lavoura e os engenhos de açúcar. (MELLO, 2001, p. 69-70) O algodão ali produzido e exportado principalmente para a Inglaterra e para a França, a partir de 1808 superou as exportações de açúcar, cultivado na mata sul, e promoveu o crescimento das atividades comerciais em Recife. Tais transformações não deixavam de repercutir no Recife, principal porto e núcleo polarizador da região; sua população era estimada em 25 mil habitantes pelo viajante inglês Henry Koster, em 1809. Na década seguinte, tornar-se-ia o "fulcro da nova fase de agitação nativista" (MELLO, 2001, p. 71).

O jovem José Inácio cresceu no Recife, onde sob a orientação do pai foi iniciado no estudo das humanidades - latim, filosofia, retórica, inglês e francês.

Aos 17 anos, tendo concluído os estudos preparatórios, iniciou o curso regimental de artilharia em Olinda (MACEDO, 1876, p. 423). Simultaneamente partilhava com o Padre Roma um interesse crescente pela literatura e aprendia as primeiras noções de grego. É possível imaginar que nas horas dedicadas ao prazer da leitura o rapazinho também ouvisse o pai relembrar passagens de sua vida - histórias sobre os estudos realizados em Coimbra; a ordenação em Roma; e a resolução de abandonar o sacerdócio. Mas, é também de se supor que José Inácio, como outros jovens de sua idade, tenha ouvido falar dos Suassunas e da conjura de 1801; tenha ouvido falar - participado mesmo, quem sabe? - do Aerópago de Itambé, escola de ensinamentos filosóficos e administrativos, sob a orientação de Arruda Câmara, em Goiana, freqüientada pela melhor gente moça de Pernambuco e das capitanias vizinhas, como era o caso de José Martiniano; da instalação da Família Real portuguesa no Rio de Janeiro... E ainda a respeito dos pernambucanos de nascimento ou adoção que faziam o grande comércio, e durante meses e até mesmo anos viviam distante, no Rio de Janeiro, em Lisboa, em Londres. E também tenha ouvido ou lido notícias sobre o final da Guerra dos Sete Anos; a respeito da luta pela independência dos americanos ingleses das Treze Colônias; sobre as transformações revolucionárias que abalavam a Europa desde 1789; sobre a luta pela abolição da escravidão deflagrada pelos negros haitianos em 1794; assim como a respeito de homens, engajados e esperançosos, que haviam atravessado fronteiras, línguas, lealdades a soberanos e Estados, obrigações ou convicções pessoais, para construir "um edifício coletivo, 
ou seja, essa Wissenchaft moderna que abarca a amplitude total da atividade intelectual, ciência e erudição" (HOBSBAWN, 1998, p. 240). E, por que não, ainda haja escutado murmúrios sobre reuniões secretas que, varando as madrugadas, congregavam homens que discutiam o tempo presente e ousavam imaginar o amanhã. ${ }^{15}$

Ao término do primeiro ano em Olinda, José Inácio embarcou para o Rio de Janeiro, onde foi aceito como aluno na Real Academia Militar, criada pelo Príncipe-Regente Dom João no ano anterior. José Martiniano permaneceria em Olinda como seminarista.

Era precária - e, como destaca Adriana Barreto de Souza, "formalmente desmilitarizada" - a formação acadêmica oferecida pela Real Academia Militar. A instituição que objetivava fundamentalmente ensinar importantes doutrinas para a defesa do território, “[...] era apresentada como um 'curso regular de ciências exatas, de observação, de todas as matérias que contêm aplicação aos estudos militares e práticos constitutivos da ciência militar' [...]" O curso funcionava em regime de externato, e deveria ser completo em sete anos. Todavia,

[...] não era concluído integralmente por todos os alunos. Aqueles que se destinavam às armas de infantaria e cavalaria apenas estudavam as armas do primeiro ano (matemática elementar) e os assuntos militares do quinto ano. Só dos artilheiros e engenheiros era exigido o curso completo. Por isso, essas armas eram mais prestigiadas, sendo consideradas 'científicas'. Requeriam de seus alunos estudos de matemática superior, fortificação e balística. Vale destacar ainda que as armas não constituíam tal, como hoje, linhas específicas de estudos militares. (SOUZA, 2004).

Segundo o dicionarista Pereira da Costa (1982), por seu bom desempenho no estudo das matemáticas, o cadete José Inácio fez jus a várias premiações ao longo de toda a sua formação.

\footnotetext{
${ }^{15}$ Sobre as relações entre narrativa, prova documental e possibilidades, cf. Carlo Ginzburg (1991).
} 
Mas a vida de José Inácio no Rio de Janeiro não seria marcada apenas pela experiência da academia militar. A instalação da Corte portuguesa modificara fundamente a vida da cidade tornada sede da monarquia portuguesa e centro do projeto de um novo império. A população da cidade crescera - dos 43 mil habitantes de 1799 passara para cerca de sessenta mil por ocasião da instalação da Corte em 1808, alcançando aproximadamente $80.000 \mathrm{em}$ 1819 -, e suas funções administrativa e portuária foram aprofundadas, ao mesmo tempo em que era vivenciado um processo de reeuropeização. O Rio de Janeiro capital do Reino tornarase o ponto de encontro de burocratas e militares, de negociantes e capitalistas, de nobres e delegações diplomáticas, aos quais se juntavam os plantadores escravistas (MATTOS, 2003, p. 48). No cenário da cidade, emergia uma nova cultura política que, segundo Morel, servia-se de "expressões manuscritas, verbais e gestuais" que não só não desapareceram após a consolidação da imprensa periódica como continham aquilo que, em geral, não podia ser impresso ou mesmo falado dentro dos limites vigentes, e assim permitiam envolver setores mais amplos do que o público habitualmente leitor ou redator.

A cidade que se diferenciava aceleradamente dos demais núcleos urbanos coloniais oferecia a José Inácio a possibilidade de ampliar de modo incomensurável sua experiência política e cultural. Ao lado dos colegas, em diferentes momentos, José Inácio provavelmente participou de debates, exercitou a crítica política e desenvolveu a argumentação, estabelecendo novas amizades, freqüentando o teatro, participando das celebrações oficiais e realizando outras leituras. Não é de todo improvável que tenha sido leitor dos três jornais que então circulavam nas maiores cidades tanto do Reino de Portugal quanto da América portuguesa - a Gazeta de Lisboa, o Correio Brasiliense e a Gazeta do Rio de Janeiro (MOREL, 2003, p. 11-14).

Aos 22 anos, após quatro anos de estudos incompletos, José Inácio concluiu seus estudos na academia como capitão de artilharia e professor de matemática. Então, foi enviado a Angola como membro de uma Comissão que tinha por objetivo instruir a oficialidade daquela colônia portuguesa. Em dezembro do mesmo ano retornou ao Brasil.

Regressava ao Recife, voltando ao convívio da família e dos amigos que não via desde 1812. Regressava a Pernambuco onde sopravam ventos revolucionários. Cresciam por toda a 
parte o descontentamento com a política joanina e o sentimento de oposição aos portugueses que haviam transformado o Rio de Janeiro em uma "nova Lisboa". "Ajuntamentos noturnos" - conforme sublinhavam as autoridades do Estado joanino - eram realizados nas casas de Antônio Gonçalves da Cruz, o Cabugá, e do padre João Ribeiro Pessoa, sendo que deste, considerado "pessoa suspeitíssima" por aquelas mesmas autoridades, diria Henry Koster jamais ter visto dirigir "uma só palavra áspera a ninguém”. No entender de Evaldo Cabral de Mello, ressuscitava-se, então, uma teoria contratualista das relações entre a Capitania e a Coroa. Destaca o autor que a teoria era

[...] inspirada visivelmente nas doutrinas constitucionais da Restauração portuguesa, enquanto entre el-rei e as demais capitanias do Brasil prevalecia uma sujeição natural, a subordinação pernambucana era de cunho eminentemente político, pois decorrente de uma opção (MELLO, 2001, p. $51)$.

Um mês após sua chegada ao Recife, José Inácio foi preso, acusado de crime de assuada, resistência e ferimentos, e enviado à Bahia no início de fevereiro de 1817.

Em março teve início a Revolução Pernambucana. Seus líderes sabiam ser tarefa urgente expandir o movimento pelas demais capitanias, em especial aquelas que gravitavam em torno do Recife. Enquanto José Martiniano seguiu para o Ceará, tendo conseguido no Crato a adesão do padrinho, o Padre Roma foi enviado à Bahia como representante do Governo Provisório constituído revolucionariamente em Recife.

Iniciava-se para todos uma fase de provações e sofrimentos. José Martiniano e sua mãe, a matriarca Dona Bárbara de Alencar, foram presos e levados para Fortaleza; dali, para Pernambuco; e, finalmente, à Bahia, onde passaram quatro anos encarcerados. O Padre Roma foi preso mal chegara a Salvador, e sumariamente condenado à morte. José Inácio e seu irmão, Luiz Inácio Ribeiro Roma, que nesta cidade também se encontrava encarcerado, presenciaram o fuzilamento do pai. 
Em outubro, os dois irmãos conseguiriam fugir da prisão. Com a ajuda de sociedades maçônicas partiram para os Estados Unidos da América, à procura do Cabugá, que lá se refugiara. Mas na jovem república norte-americana não permaneceriam por muito tempo, seguindo para as Antilhas. Ali, Luiz Inácio decidiu viver na ilha de São Tomás, ao passo que José Inácio dirigiu-se à Venezuela, levado por um dos diretores de um periódico ligado a Simon Bolívar - o Correo del Orinoco. Tinha início a experiência do exílio.

Então, não eram apenas os dois irmãos que se separavam. A experiência do movimento de 1817 - ainda que não apenas ela - imprimiria sentidos diversos às trajetórias dos dois josés. Afinal, se a vivência de experiências comuns possibilita a um conjunto de homens e mulheres sentir e identificar seus interesses como algo que lhes é comum, ela possibilita também se contrapor a outros grupos de homens e mulheres cujos interesses se apresentam como diferentes e mesmo antagônicos aos seus (THOMPSON, 1987, p. 9-14). Experiências que possibilitavam formular projetos.

Admitido como capitão de artilharia no exército venezuelano, em 1819, José Inácio foi por Simon Bolívar agraciado com o título de Libertador de Nova Granada, nomeado membro da Ordem Militar dos Libertadores da Venezuela e promovido a capitão.

No decorrer dos anos 20, combateu ativamente em diversas campanhas militares, participou da criação da República da Colômbia, lutou pela libertação do Peru e pela criação da Bolívia.

Vinte e seis anos depois, nas páginas do Compêndio da História do Brasil de sua autoria, ele rememoraria para seus leitores os infaustos sucessos de 1817:

Um homem houve que, conhecendo a importância de dar mais impulso àquele movimento, se ofereceu para ir às Alagoas, e dali à Bahia, correndo ele só todo o risco de sua temerária empresa.

Este cidadão era o doutor José Inácio de Abreu e Lima, um dos mais hábeis advogados de Pernambuco, vulgarmente conhecido depois de sua infausta morte pela denominação de Padre Roma. Suas relações na parte meridional 
da Província the inspiravam grande confiança, e na verdade sua marcha até Alagoas foi um constante triunfo; por toda parte consegue fazer com que os povos e as autoridades se decidam pela revolução; e quando julga oportuno, volta a Maceió, freta uma balsa, e se dirige para a Bahia. Abreu e Lima, sem embargo de seus variados conhecimentos, era homem, como todo os seus correligionários, inexperiente dos manejos ocultos das revoltas; sem nenhum disfarce, apresentou-se sempre, desde que saiu do Recife, como se fosse o emissário de um governo autorizado. Ainda antes de sua marcha, sabia-se geralmente qual era a sua missão e dela tinha sido informado o Conde dos Arcos na Bahia com muita antecipação; assim foi que ao saltar em terra no lugar da barra, foi logo preso e conduzido à cadeia da Cidade.

Por uma espécie de pressentimento teve ele o bem acordo de lançar à água todos os papéis, que levava consigo, não só proclamações como várias cartas para os indivíduos relacionados com os liberais de Pernambuco; mas isto só serviu para alentar na covardia aqueles mesmos, que o deixaram sacrificar sem nenhuma mostra de gratidão. O Conde dos Arcos tinha já em seu poder, o corpo de delito, que era a ata de eleição do governo provincial de Pernambuco, na qual seu nome aparecia em segundo lugar. Verificada a identidade da pessoa, foi julgado por uma comissão militar, condenado à morte, e fuzilado no dia 29 de março no Campo da Pólvora. O seu porte em presença do Conselho, no Oratório, e durante o trajeto para o lugar do suplício, foi sempre o de um filósofo cristão, corajoso, senhor de si, mas tranqüilo e resignado. Suas faces não se desbotaram senão quando o sangue, que as tingia, correu de suas feridas, regando o solo onde, seis anos depois, se firmou para sempre a independência da sua pátria.

E acrescentava, por meio de uma nota:

Meu pai foi preso ao anoitecer de 26 de Março; no dia seguinte fizeram-se todas as perguntas de costume, confrontação de testemunhas, e nomeou-se a Comissão Militar, que o devia julgar; no dia 28 foi condenado à morte, e passou para o Oratório às três horas da tarde; foi fuzilado às oito da manhã do dia 29. No momento que escrevo estas linhas, assalta-me todo o horror daquela tremenda noite, em que fui quase companheiro da vítima: era eu que 
parecia o condenado, e não ela. Tenho visto morrer milhares de homens nos campos de batalha, e muitos nos suplícios, mas nunca presenciei tanta coragem, tanta abnegação da vida, tanta confiança nos futuros destinos de sua pátria, tanta resignação em fim: uma mão de ferro me arrancava o coração; meu pranto e minha dor comoviam a todos que se achavam presentes; era mister separar-me para dar alívio às minhas lágrimas, e me conduziam à outra prisão, donde voltava depois a poder de minhas súplicas, até que foi forçoso arrancarem-me de seus braços para sempre.

Uma circunstância mais que todas vinha de quando em quando agravar essa espécie de martírio, com que os algozes de meu pai queriam amargurar ainda mais seus últimos instantes: meu irmão, pessoa de compleição mui débil e delicada, fora preso em sua companhia, e achava-se metido em um dos imundos calabouços do Oratório chamado segredo. $\mathrm{Nu}$ em carne e estendido sobre a lama, mais parecia um espectro do que um ser vivente; coberto de lodo faziam-no sair algumas vezes para que meu pai o visse: nesse momento terrível para seu coração de pai, parecia comovido, beijava meu irmão, e como para distrair-se dirigia a palavra a algum dos Sacerdotes, que o acompanhavam. Com toda essa prova tremenda de brutal ferocidade não fez desmentir um só instante sua resignação como filósofo nem como cristão. Chegando ao lugar do suplício, fez um pequeno discurso alusivo à sua situação, e desculpando os soldados do ofício de algozes; depois, pediu que atirassem com sangue frio para não martirizá-lo, e levando ambas as mãos algemadas ao peito fez delas o alvo de seus tiros. Durante o Conselho protestou contra a sua competência, defendeu-se sem inculpar ninguém e negou-se a todas as sugestões, que lhe fizeram, para descobrir o objeto de sua missão; no Oratório ninguém lhe ouviu uma queixa contra pessoa alguma, e no lugar do suplício excedeu a todos em longanimidade a todos quantos o precederam na mesma desgraça da sorte. Os baianos viram como morre um homem livre; a lição devia ficar-lhes impressa. (ABREU E LIMA, 1843a, p. 283-285).

A narrativa oferecida à "mocidade Brasileira" que ele pretendia formar como patriota e brasileira a um só tempo tinha como objetivo evidente propiciar o conhecimento de uma experiência tida como exemplar: a luta para se emancipar de um poder absoluto, limitador ou 
supressor da liberdade. Ao recuperar a estreita relação entre história e política, ela punha em relevo a história como mestra da vida. Para seu autor, porém, ela significava talvez algo diverso. Como um exercício de rememoração, ela sublinhava uma espécie de inflexão em uma deliberação consciente. Ela possibilitava ao autor de Compêndio recordar como, naquela ocasião, começara a deixar de ser José Inácio, o filho do padre Roma, tornando-se aos poucos Abreu e Lima.

Trajetória diversa a de José Martiniano, desde então. Saído do cárcere na Bahia, elegeu-se deputado às Cortes de Lisboa. Quando as notícias dos acontecimentos do Rio de Janeiro no segundo semestre de 1822 chegaram a Portugal, anunciando a separação entre os dois reinos, fugiu para a Inglaterra, uma vez que as autoridades do antigo Reino lhe haviam negado passaporte. Da velha Albion retornou ao Brasil. Elegeu-se para a Assembléia Constituinte de 1823, que em novembro seria fechada pelo primeiro imperador do Brasil. O autoritarismo de Dom Pedro I e os vínculos familiares empurraram-no para a Confederação do Equador, do que resultou nova prisão ainda em 1824. Quatro anos depois seria eleito deputado geral; em 1832, tornou-se o primeiro senador escolhido pelo governo regencial. Pouco mais tarde, foi nomeado Presidente da província em que nascera. Tornara-se um dos construtores do Estado imperial. Sem abandonar as hostes liberais, tornara-se um representante da Ordem. Ou de uma das ordens possíveis.

Quarenta e dois anos após os acontecimentos que convulsionaram Pernambuco, ele podia ser encontrado entre "Os contemporâneos", na Galeria dos brasileiros ilustres de Sisson. Mas Abreu e Lima ali não encontraria lugar. O perfil de José Martiniano de Alencar era traçado pelo próprio filho, já romancista já famoso:

[...] Alencar, uma das popularidades de 1830, um dos homens mais notáveis da oposição de 1839, um dos autores da revolução parlamentar que produziu a maioridade em 1840, só aspira a servir a seu país com o seu voto de legislador, e a conservar puras e inalteráveis as crenças políticas que o dirigiram durante a sua vida (SISSON, 1999, p. 250). 
Todavia, os inúmeros e relevantes serviços prestados ao Império do Brasil por José Martiniano não foram suficientes para lhe atribuir uma identidade própria. Para a grande maioria dos brasileiros, ele se tornara o avô de Peri.

\subsection{Emancipar}

Entre a partida de José Inácio e a chegada de José Martiniano ao Rio de Janeiro, inúmeros e diferentes sucessos marcaram a vida dos habitantes da cidade. Como a chegada da missão artística chefiada pelo barão Georg von Langsdorff, da qual fazia parte o desenhista Johann Moritz Rugendas.

Desentendimentos com o chefe da missão fizeram Rugendas abandoná-la. O desenhista natural de Augsburg decidiu, então, percorrer o país, representando em gravuras tudo aquilo que se apresentava como original, gracioso, envolvente e fascinante; tudo o que era digno de ser pintado - tudo o que era "pitoresco", em suma. Agregando às gravuras textos - cuja imprecisão eventual de dados não é suficiente para anular a observação arguta e uma sensibilidade fina - Rugendas compôs Voyage Pittoresque dans le Brésil, publicado em 1835 (RUGENDAS, 1967).

Dos registros de Rugendas sobre a cidade à época da emancipação política, escolho uma gravura e um fragmento de texto.

A gravura representa a "Rua Direita", a mais importante da cidade. Traço de união entre os morros do Castelo e de São Bento, ela atravessa o Largo do Paço, o qual se abre para o porto (cf. Anexo I).

O fragmento de texto faz referência aos acontecimentos que conduzem à separação entre os reinos de Portugal e do Brasil:

[...] os habitantes do Brasil não pensavam em intrometer-se nos negócios públicos, nem julgar os atos dos seus dominadores; foram os governos da Europa que lhos ensinaram, por meio de proclamações ao povo e de apelos à 
opinião, a qual, até então, não tivera talvez sequer o sentimento de sua própria existência. Esse espírito público age, no sul, de uma maneira ainda mais forte do que no norte, e, embora a imprensa não seja livre, os discursos são mais animados e as reuniões mais freqüentes. A Porta do Sol em Madri, o Rocio em Lisboa e a praça de igual nome que se situa em frente ao palácio do Rio de Janeiro são, para a vida intelectual, centros de ação cuja importância não pode ser apreciada nas frias regiões do norte. Não é de estranhar que a opinião pública se pronuncie mais favoravelmente ao Governo atual, no Rio de Janeiro, do que em qualquer outra parte do Brasil. Não somente a presença do Imperador e da Corte traz para a Capital grandes vantagens materiais, de que são privadas as outras partes do Império, mas ainda o aspecto pessoal do jovem príncipe garante-lhe merecida popularidade todas as vezes que se mostra em público.

Ambos - texto e gravura - transmitem movimento.

Da gravura saltam brancos, pardos e negros; homens livres e escravos; negros de ganho e de aluguel; mercadores e militares; homens a pé e uns poucos a cavalo; desocupados, mendigos e ciganos; mulheres negras e homens com espada à ilharga; um "certo ar oriental" observado por von Martius por essa mesma época, que a reeuropeização propiciada pela instalação da Corte não conseguira apagar. O movimento do porto e dos negócios parece contagiar a todos, direta ou indiretamente, comandando a faina cotidiana, como tradução das transformações vividas pela cidade desde 1808.

Um movimento diverso distingue o texto. Anima-o não o movimento da vida cotidiana e dos negócios, e sim a emergência de uma nova cultura política. No espaço da cidade, em especial "na praça [...] se situa em frente ao palácio do Rio de Janeiro", que Rugendas denomina equivocadamente de Rocio, essa nova cultura política se distingue não apenas por se contrapor à cultura política do Antigo Regime. Ela se distingue, sobretudo, por forjar uma "opinião pública", por estar referida ao constitucionalismo e - aspecto mais do que significativo - por transbordar dos salões e gabinetes para as ruas e praças. O "espírito 
público" fazia com que os habitantes se intrometessem, cada vez mais, nos "negócios públicos”, julgando "os atos dos seus dominadores".

Movimentos diversos os da gravura e do texto, mas que guardavam relação, de modo direto ou não, com os acontecimentos que imprimiam um rumo e um ritmo diverso ao mundo atlântico, especialmente em sua face colonial, desde o fim da Guerra dos Sete Anos. A eles se somariam os eventos do movimento constitucionalista do Porto, em 1820. Acontecimentos cujas idéias que deles faziam homens e mulheres que habitavam a cidade do Rio de Janeiro acabavam por orientar seu proceder, tornando-os protagonistas privilegiados no forjar de algo distinto.

Eric J. Hobsbawn (1977) ao pôr em destaque a "dupla revolução" - a Revolução Industrial inglesa e a Revolução Francesa - reuniu os elementos históricos fundamentais para caracterizar, em texto exemplar, a "Era das revoluções". Suscitando esperanças e medos, fé inquebrantável no progresso e invenções de tradições, ações e reações, a "Era das revoluções" propiciava também uma nova cultura política, e por ela era conformada.

A Reinhart Koselleck não foram estranhas tamanhas transformações. Mas ele as considera de um ponto de vista diverso. Tomando como referência a experiência alemã, Koselleck sublinha o fato de os vocabulários políticos e sociais terem se transformado em ritmo acelerado e em determinadas direções específicas, particularmente durante o período que denomina de Sattelzeit, o qual se estende de 1750 a 1850, aproximadamente. Então, e de modo sumário, teriam ocorrido quer uma democratização daqueles vocabulários, até então especializados e relativamente restritos às camadas das elites, quer a sua politização e ideologização, os conceitos políticos e sociais deixando de se referir com exclusividade aos estados e ordens característicos da sociedade do Antigo Regime para se tornarem não só cada vez mais genéricos em sua referência social e abstratos em seu significado, como também suscetíveis de serem utilizados como instrumentos de combate por classes, estratos e 
movimentos antagônicos. Ao mesmo tempo, um modo novo de conceptualizar e operar com o tempo e com a História fundavam um "horizonte de expectativas." 16

Com certeza, o processo identificado por Koselleck não era exclusivo dos territórios alemães, podendo ser identificado também em outras sociedades, em graus variados, em ambos os lados do Atlântico. Não por acaso, a sensibilidade do alemão Rugendas registraria algo semelhante entre "os habitantes do Brasil”; mas não deixaria de sublinhar terem sido "os governos da Europa que lhos ensinaram, por meio de proclamações ao povo e de apelos à opinião, a qual, até então, não tivera talvez sequer o sentimento de sua própria existência".

No Rio de Janeiro, no início dos anos 20 do penúltimo século, nas ruas e praças, nos teatros e nas portas das igrejas, proclamações, folhetos, pasquins, catecismos políticos, cantigas e gestos constituíam indicadores da democratização, politização e ideologização dos vocabulários políticos e sociais, configurando uma nova cultura política; eram também fatores dela constitutivos. Revelavam, ainda, as expectativas de homens e mulheres, empenhados em fazer sua própria história, porque empenhados em se emancipar dos inúmeros constrangimentos a que estavam sujeitos.

E assim permaneceria pelos anos seguintes. Falando dos tempos de sua infância, nos anos iniciais do Período Regencial, um memorialista recordaria:

Nasci e me criei no tempo da regência; e nesse tempo o Brasil vivia, por assim dizer, muito mais na praça pública do que mesmo no lar doméstico; ou em outros termos, vivia em uma atmosfera tão essencialmente política que o menino, que em casa muito depressa aprendia a falar liberdade e pátria, quando ia para a escola, apenas sabia soletrar a doutrina cristã, começava logo a ler e aprender a constituição política do Império. (RESENDE, 1944, p. 67).

\footnotetext{
${ }^{16}$ Cf. R. Koselleck (1993), entre outros textos do autor.
} 
Novas atitudes que atestavam a circulação de textos e de idéias. Ela ocorria em escala crescente desde fins dos setecentos, não obstante as reiteradas proibições e monopólios estabelecidos pelas autoridades coloniais. Mas circulação de homens e mulheres também, portando idéias e carregando textos: caixeiros-viajantes, clérigos, letrados, marinheiros, militares; homens e mulheres imbuídos das “infames idéias francesas”.

A instalação da Corte portuguesa no Rio de Janeiro atribuiria posição de destaque à cidade, tornando-a pólo de atração. Desde então, e, sobretudo, após a emancipação política, ela se tornaria o ponto de referência da trajetória de muitos, ainda que por caminhos muitas vezes tortuosos, como fora o caso de José Martiniano. Da terra de seus pais à Corte; da Corte a sua pátria, ou ainda a outros locais, mas sempre no interior do Império, percorrendo um território herdado dos colonizadores, por caminhos terrestres ou em embarcações que seguiam por roteiros marítimos e fluviais, levando novos hábitos e idéias, carregando novos textos, tecendo lentamente uma unidade e ajudando a construir a imagem de brasileiro.

Mas a Corte não era o destino de todos, necessariamente, conforme o revelavam as experiências de José Inácio, do Cabugá e de outros participantes da Revolução Pernambucana de 1817. O Atlântico era o caminho de que se serviam para alcançar outros pontos da América hispânica, da América inglesa, do Caribe e da própria Europa; o Atlântico era uma espécie de grande tela onde os fios das experiências vividas e aqueles das experiências dos homens e mulheres com quem se encontravam teciam novas solidariedades, ajudavam a suportar infortúnios e alimentavam esperanças. Assim também o revelam as trajetórias de vida do enigmático padre Joaquim de Souza Ribeiro e do pardo Emiliano Benício Mundurucu, cujo "nome aparece vinculado às questões em torno das lutas republicanas e da liberdade dos escravos nos anos 1820, não apenas no Brasil, mas em outras partes da Américas por onde passou", rastreadas por Flávio Gomes e Marco Morel (2003, p. 37-63). Circulando um José Inácio e um padre Joaquim Ribeiro fora de um território herdado, não querendo ou não podendo privilegiar a Corte em seus roteiros, acabavam por despertar temores, sendo olhados com desconfiança e associados ao republicanismo, ao haitianismo e a tantos outros medos que, eles também, não cessavam de circular. 
As experiências do padre Joaquim Ribeiro e de Emiliano Mundurucu possibilitam acrescentar algo mais a tudo isso.

De modo quase complementar à contribuição de Hobsbawn, Robin Blackburn chama a atenção para a face colonial e escravista do mundo atlântico, pondo em evidência o quadro que se delineia após a conclusão do Tratado de Paris, que pôs fim à Guerra dos Sete Anos. Destaca o autor que

[...] a Guerra dos Sete Anos teve mais efeitos desorganizadores sobre os sistemas de escravidão colonial do que todas as guerras que a precederam. Ela envolveu todas as grandes potências atlânticas, despertou vários sentimentos patrióticos e terminou com uma paz prenhe de conflitos futuros. A guerra fez com que os quacres da Filadélfia começassem a se dissociar da escravidão, enquanto a paz armava o cenário para a rebelião dentro dos impérios britânico e francês. Brigas políticas seculares e o debate da adequada natureza do espaço público deram mais abertura aos que desafiavam a escravidão no Novo Mundo. (BLACKBURN, 2002).

Ao procurar compreender por que nos Estados Unidos da América e no Brasil a emancipação política não foi acompanhada pela supressão da escravidão negra, e por que no Caribe britânico e francês a abolição do trabalho escravo não conduziu à supressão do domínio colonial, enquanto no Haiti e em várias regiões da América hispânica tanto a abolição da escravidão quanto a independência política foram conquistadas, entre outras questões relevantes, Blackburn traça um grande arco que se estende da revolução haitiana em 1794 à abolição da escravatura no Império do Brasil em 1888: a "Era da Abolição".

Consideradas de um ponto de vista complementar, a "era das revoluções" e a "era da abolição" permitem perceber como ganhara relevância para homens e mulheres, homens livres e escravos, em ambos os lados do Atlântico, no território do Império do Brasil ou fora dele, na Corte e nas províncias, uma das categorias chaves da experiência moderna do tempo: emancipação. 
Em 1828, por meio de uma questão, H. Heine sublinhava aquela importância:

"Qual é a grande tarefa do nosso tempo? É a emancipação.”

E acrescentava que ela se estendia aos irlandeses, aos gregos, aos judeus de Frankfurt, aos pretos, à Europa e ao mundo inteiro.

Miguel Baptista Pereira (1990, p. 96) recorda que

[...] em 1831, falava-se da emancipação das instituições, em especial da escola relativamente à Igreja, da Igreja frente ao estado ou quanto a Roma e da emancipação de grupos como povos, judeus, mulheres, escravos e trabalhadores. No fim dos anos 30, emancipação torna-se o conceito condutor de toda a história passada e futura e, por isso, acentua-se a articulação entre todas as emancipações dos Tempos Modernos, v.g., da mulher, dos estados americanos, dos escravos negros, dos judeus e da França, que pela revolução se emancipou do passado.

A emancipação apresentava-se como um projeto e um programa; não deixava de se apresentar também como uma espécie de guia para a ação por meio de inúmeros textos, que não cessavam de circular. Textos que se ofereciam à leitura de josés, bernardos, evaristos, antônios, joaquins, bárbaras, marias, anitas e muitos mais. Leitores que se apropriavam das idéias neles contidas e das experiências ali relatadas, de uma maneira particular, porque era diferente o lugar onde liam. Eram leitores em situação colonial (FALCON, 2004).

José Inácio de Abreu e Lima era um deles.

\subsection{Americano, brasileiro ou pernambucano?}

O engajamento de José Inácio nas lutas pela emancipação política da América hispânica não se restringiu às ações militares. Aos 28 anos, tendo sido promovido a coronel, 
exerceu uma função diplomática. Nomeado "Enviado extraordinário" por Bolívar, viajou aos Estados Unidos, tendo por missão a resolução de assuntos referentes a problemas políticos relacionados ao Peru e à Bolívia, assim como a compra de armamentos para as forças revolucionárias.

O exílio reforçaria o apego de José Inácio às letras, mas não mais apenas como leitor. Aventurando-se como escritor, publicou artigos em periódicos locais, editou pasquins. A pedido do general Santander redigiu "Memórias sobre os limites entre o Brasil e a República da Colômbia". Iniciou também a redação de uma biografia sobre Bolívar, ouvindo suas histórias, observações críticas e consultando documentos tornados disponíveis pelo próprio Libertador.

Diferentes motivos, embora certamente todos referenciados pela situação de exílio, conduziram-no a encontros com compatriotas, em serviço oficial ou exilados como ele próprio, a quem ofereceu ajuda. Um deles foi José da Natividade Saldanha, o antigo revolucionário de 1817 (CASTRO 1989, p. 164-165). Livros, jornais e panfletos também contribuíam para que se mantivesse informado a respeito do que ocorria no Reino do Brasil às vésperas da emancipação, aguçando seus desejos de uma participação política ativa. Em meados de 1822, por meio do Cabugá, ofereceu ajuda ao príncipe D.Pedro. E também ao Brasil, revelando como também se incluía entre os herdeiros de um nome e de um território. Aspirava regressar ao cenário principal daqueles acontecimentos emocionantes.

Em 1823, em carta dirigida ao general Santander, externava sua opinião a respeito do regime monárquico no Brasil, sublinhando uma quase inevitabilidade:

Os brasileiros (sic) serão independentes, serão livres, ricos, poderosos, etc, etc, mas terão sempre um monarca, e isto não me agrada, embora seja eu de opinião que foi o passo mais acertado; qualquer outra forma de governo, têlos-ia confundido, e reduzido a uma completa anarquia e dissolução; o Brasil é imenso, povoado somente nas costas, e com uma mistura de classes que nunca poderiam ligar-se sob outro sistema que o separasse muito da forma antiga. 
Ao mesmo tempo, comentava a respeito de ter o governo imperial indenizado sua família pelos bens confiscados em 1817.

Tive cartas de minha mãe; todos os bens de meu pai foram restituídos e, dos que haviam sido arrematados, mandou-se restituir o dinheiro; minha mãe exige-me procuração, e mandei-a para realizar os meus bens; já vê que é um grande consolo.

E ainda afirmava a intenção de “[...] lutar pela Colômbia, enquanto houvesse um inimigo a combater", ao mesmo tempo em que procurava marcar sua diferença em relação aos demais estrangeiros que lutavam pela emancipação:

"Eu sou americano; não sou estrangeiro, e não quero confundir-me com a turba dos que vieram só desfrutar essa vantagem." (ABREU E LIMA, Carta de 14 de junho de 1823).

Uma auto-identificação que se apresentava como um desafio: dizia-se americano; não se apresentava - não se sentia à vontade, talvez - como brasileiro; não abria mão de uma identificação como pernambucano.

Na mesma carta, Abreu e Lima insistia para ser enviado ao Rio de Janeiro como Secretário da Legação do Governo da Colômbia, argumentando falar o idioma, conhecer o país e as intrigas da Corte, "porque vivi sempre delas".

Mas aquele que ia se transformando em Abreu e Lima distinguia-se também por não desistir com facilidade de suas intenções. Em 1825, enviou ao governo imperial um pedido para regressar ao Brasil. O retorno lhe foi negado com base na Constituição do Império do Brasil, cujo artigo $7^{\circ}$, parágrafo $2^{\circ}$, determinava que todo aquele "que, sem licença do Imperador, aceitar emprego, pensão ou condecoração de qualquer governo estrangeiro, perde 
os direitos de cidadão brasileiro". Seu desconforto aumentaria, com toda a certeza, ao ser informado, pouco tempo mais tarde, que aqueles mesmos que haviam lhe negado a solicitação, haviam-na concedido a Luis Inácio Ribeiro Roma.

Tendo vivido os tempos do exílio, antes de tudo, "como um americano", em suas próprias palavras, e participado apaixonadamente de acontecimentos políticos, sociais e culturais tanto na Venezuela como na Colômbia, decidiu partir em definitivo após a morte de Bolívar, em 1830. Partia como general - General de Bolívar - doze anos após ter chegado à Venezuela.

Viajou para os Estados Unidos da América do Norte; ali, da Filadélfia, em julho de 1831, escreveu aos irmãos que já se encontravam no Brasil:

[...] morto Bolívar por quem faria eu mais sacrifícios? [...] Ocorreu-me ir imediatamente ao Brasil, e evitar de algum modo os horrores da guerra civil. Eu tenho na América do Sul uma reputação militar que não quero perder em uma hora, havendo-me custado 14 anos de sacrifícios, de batalhas e de feridas. Soube que vocês têm sido muito perseguidos pela administração do Imperador; porém isso já se acabou, e é necessário agora ser generosos... a nenhum homem é lícito ser assassino, debaixo de qualquer aspecto... Contem vocês comigo dentro de seis meses, sem falta alguma, apresentar-me-ei como cidadão para viver tranqüilo, ou como general e soldado para servir a minha pátria, empregando a minha espada na conservação dos imprescritíveis direitos de meus cidadãos: se chegar a desembainhá-la no Brasil, não a embainharei sem ter cumprido o meu dever: porém agora estou mui longe de poder julgar o que me convém. Por Deus, meus irmãos, não se comprometam com partido algum, até a minha chegada. ${ }^{17}$

Seguiu, todavia, para a Europa. Em Paris, onde permaneceria por mais tempo, encontrou-se com D. Pedro I, que acabara de abdicar ao trono do Império do Brasil. Só em

\footnotetext{
${ }^{17}$ O trecho da carta foi transcrito por Evaristo da Veiga na Aurora Fluminense: Jornal Político e Literário, edição de 1 de março de 1833, com propósitos evidentemente diversos.
} 
fins de 1832 iniciaria a viagem de retorno ao Brasil. Tinha a seu lado um companheiro inseparável.

\subsection{Um companheiro inseparável}

Aos 39 anos, Abreu e Lima retornava à Corte imperial. Todavia, aquele não seria um ponto de chegada! A longa viagem da emancipação, havia muito iniciada, não encontraria ali sequer um ponto de repouso.

Mas, no prosseguimento da viagem, já não podia estar ao lado do Libertador. Este, porém, estaria sempre a seu lado, como um companheiro inseparável ou um guia providencial. O fascínio por Simón Bolívar fizera com que Abreu e Lima desse início, ainda no exílio, à redação de uma biografia daquele que infringiria às tropas espanholas a derrota decisiva em Ayacucho, ouvindo suas histórias, observações críticas e consultando documentos tornados disponíveis pelo próprio Libertador, conforme observei há pouco. Todavia, aquele leitor voraz e escritor ativo, sempre pronto para os embates também no campo das letras e das idéias, somente a concluiria já no terço final de sua vida, no Recife. E, coisa ainda mais espantosa: daquela biografia, ao que consta, os brasileiros somente tomariam conhecimento em 1922, quando das comemorações do centenário da Independência, ocasião em que Diego Carbonell, embaixador da Venezuela no Brasil, tomou a iniciativa de publicar, pela primeira vez, o Resumo Histórico da última ditadura do Libertador Simón Bolívar, acompanhado por biografia e notas de sua autoria.

O Simon Bolívar "pragmático, controverso, ambíguo e até mesmo contraditório”, na precisa caracterização de Maria Lígia Coelho Prado (2007, p. 5) - e não o Simon Bolívar "otimista, coerente, defensor da liberdade, da democracia e das causas sociais e precursor do anti-imperialismo", inventado e reinventado por biógrafos e políticos, desde o século XIX aos dias de hoje - acompanharia para sempre o também ambíguo, controverso e não raro contraditório Abreu e Lima no desdobramento de sua longa viagem iniciada desde o seu regresso ao Império do Brasil. Pelo pernambucano que estava se tornando brasileiro, Bolívar seria também inventado e reinventado, em sucessivas apropriações que assinalavam também a troca que realizava da espada pela pena, como condição para estar na praça pública. 
Seguir pelos textos de Abreu e Lima, manuscritos ou impressos, é ter a possibilidade de identificar, ao menos em parte, aquelas apropriações; é ter a oportunidade de sentir o Simon Bolívar que permaneceria para sempre em Abreu e Lima.

Ao "filho do padre Roma" emocionaria sempre o valor que O Libertador emprestava à educação. Um valor que derivava, por certo, da influência exercida em sua formação por seu professor Simón Rodríguez, pensador fortemente influenciado pelas idéias ilustradas reformistas que se dedicou a refletir e propor soluções para as questões políticas, sociais e educacionais que afligiam a Venezuela. ${ }^{18}$ Em carta a Guillermo White, datada de 26 de maio de 1820, Bolívar afirmava não poder haver liberdade onde há ignorância, pois

[...] a escravidão é filha das trevas; um povo ignorante é o instrumento cego de sua própria destruição. [...]: Um homem sem estudos é um ser incompleto; moral e luzes são os pólos de uma República, moral e luzes são nossas primeiras necessidades.

Se em diferentes oportunidades Abreu e Lima afirmara enfaticamente - "Eu sou americano" - tal se devia, em larga medida, à caracterização feita por Bolívar da originalidade da América de colonização espanhola:

Tenhamos claro que nosso povo não é o europeu nem o americano do Norte; é muito mais um composto de África e América que uma emanação da Europa, pois até mesmo a Espanha deixa de ser européia por seu sangue africano (árabe), por suas instituições e por seu caráter. [...] É impossível afirmar com segurança a que ramo da família humana pertence [...] A maior parte do indígena foi aniquilada, o europeu foi mesclado com o índio e com o africano. Nascidos todos do seio de uma mesma mãe, nossos pais, diferentes em origem e sangue, são estrangeiros, e todos diferem visivelmente em epidermes; esta dessemelhança traz um reto da maior transcendência.

\footnotetext{
${ }^{18}$ Segundo Maria Lígia C. Prado (2002, p. 197-220), "Simón Rodríguez é pouco conhecido no Brasil, mesmo entre os estudiosos de História da Educação. Por oposição, na Venezuela, é uma referência historiográfica obrigatória, especialmente por ter sido preceptor de Simón Bolívar, que viveu em sua casa por algum tempo"..
} 
Uma originalidade que exigia um novo tipo de governo, distinto tanto daqueles existentes quer na Europa quer na jovem república norte-americana. Então, é provável que Abreu e Lima já percebesse como Montesquieu e Jeremy Bentham iam ocupando o lugar que pertencera a Rousseau, nas proposições de Bolívar - “o sistema de Governo mais perfeito é aquele que produz a maior soma de felicidade possível, maior soma de segurança social e maior soma de estabilidade política" -, que, cada vez mais, afastava-se das proposições democráticas de governo:

\begin{abstract}
Atenas, a primeira, nos dá o exemplo mais brilhante de uma democracia absoluta, e, ao mesmo tempo, a mesma Atenas nos oferece o exemplo mais melancólico da extrema debilidade dessa espécie de Governo. O mais sábio legislador da Grécia não viu sua república se conservar por dez anos e sofreu a humilhação de reconhecer a insuficiência da democracia absoluta para reger qualquer espécie de sociedade, mesmo a mais culta, morigerada e limitada porque só brilha com relâmpagos de liberdade. Reconheçamos, pois, que Sólon foi desenganado pelo mundo, que lhe ensinou quão difícil é dirigir por simples leis aos homens.
\end{abstract}

Entre a Carta da Jamaica, de 1815, e o Congresso de Angostura, em 1819, as experiências vividas fariam Simón Bolívar reelaborar suas concepções políticas, sustentado tanto que "os homens de luzes e honrados são os que devem formar a opinião pública . O talento sem probidade é um açoite", quanto o papel do Senado hereditário na organização política:

Se o Senado em lugar de ser eletivo fosse hereditário, seria, ao meu conceito, a base, o laço, a alma de nossa República. Este corpo nas tempestades políticas apararia os raios do Governo e rechaçaria as ondas populares. Adicto ao Governo pelo justo interesse de sua própria conservação, opor-seia sempre às invasões que o povo intenta contra a jurisdição e a autoridade de seus magistrados. Devemos confessar: a maioria dos homens desconhece seus verdadeiros interesses, e constantemente procura assaltá-los nas mãos de seus depositários: o indivíduo pugna conta a massa, e a massa contra a autoridade. Portanto, é preciso que em todos os governos exista um corpo 
neutro que se ponha sempre ao lado do ofendido e desarme o ofensor. Este corpo neutro, para que possa ser tal, não deve ter sua origem nem na eleição pelo Governo nem pelo povo; de modo que goze de uma plena independência que nem tema nem nada espere destas duas fontes de autoridade. O Senado hereditário como parte do povo participa de seus interesses e de seu espírito. Por tal razão não se deve presumir que um Senado hereditário se desprenda dos interesses populares, nem que esqueça de seus deveres positivos legislativos. Os senadores em Roma e os lordes em Londres têm sido as colunas mais firmes sobre as quais se tem fundado o edifício da liberdade política e civil.

Seis anos mais tarde, em pronunciamento no Congresso Constituinte da Bolívia, proporia a presidência vitalícia para o país:

O presidente da República nomeia o vice-presidente, para que administre o Estado e o suceda. Por essa providência, evitam-se as eleições, que produzem a grande calamidade das repúblicas, a anarquia, que é o luxo da tirania e o perigo mais imediato e terrível dos governos populares. ${ }^{19}$

Não obstante, é a consideração da originalidade da América de colonização ibérica reiterada na Carta da Jamaica quer por meio da referência aos "americanos meridionales", quer por meio da expressão do desejo de constituição na América do Sul da "maior nação do mundo, menos por sua extensão e riquezas, do que por sua liberdade e glória" - que levaria $\mathrm{O}$ Libertador, por essa mesma época, a realizar o Congresso do Panamá. Sublinhando a originalidade da "América" em contraposição à Europa, ao mesmo tempo que se diferenciava da proposição norte-americana, consubstanciada na Doutrina Monroe, Bolívar buscava, então, construir a unidade legal da "Confederação Americana", um conjunto constituído pelas repúblicas hispano-americanas recém-independentes. A escolha do Panamá não era aleatória, expressando a visão de Bolívar a respeito do valor estratégico e político do ístmo, ponto de união dos oceanos Atlântico e Pacífico por meio da abertura de canais, na nova configuração

\footnotetext{
${ }^{19}$ Para as diferentes citações de Simón Bolivar, cf., entre outros, Prado (2002); Jensen; Castro (1989) e BlancoFombona (s.d.).
} 
mundial que emergia da "dupla revolução" européia, da emancipação política das colônias americanas e da era da abolição.” (ANDERSON, 1989; MIGNOLO, 2003). O Império do Brasil de D. Pedro I recusaria o convite para participar do Congresso do Panamá, e tal fato também não deve ter passado desapercebido a Abreu e Lima.

\subsection{Entre a espada a pena}

Brasileiros! Um acontecimento extraordinário veio surpreender todos os cálculos da humana prudência; uma revolução gloriosa foi operada pelos esforços, e patriótica união do povo e tropa do Rio de Janeiro, sem que fosse derramada uma só gota de sangue; sucesso ainda não visto até hoje, e que deve honrar a vossa moderação, energia e o estado de civilização a que haveis chegado (apud ARMITAGE, 1965).

O trecho inicial da "Proclamação" feita por aqueles que, no momento imediatamente seguinte à Abdicação, tinham o governo do Império em suas mãos, transmitia alegria e júbilo. E isto porque uma "revolução gloriosa" pusera fim ao que era entendido como a tirania do primeiro imperador; e tal resultara da pacífica e "patriótica união do povo e tropa do Rio de Janeiro".

Mas daquela "Proclamação" - que expressava sobretudo o ponto de vista daqueles que ficariam conhecidos como Liberais moderados - destacava-se algo mais: uma surpresa. A abdicação de D. Pedro I fora um "acontecimento extraordinário". Um acontecimento que, ao "surpreender todos os cálculos da humana prudência", rompia um continuum que unia uma experiência anterior, acumulada nas lutas da oposição ao imperador, que distinguiram os anos de 1826 a 1831, às expectativas naquelas lutas forjadas, as quais não continham, certamente, a renúncia do principal mandatário do Império em nome de seu filho e herdeiro. Um continuum que deveria ser constituído novamente, impondo aos homens e mulheres que viveram como uma surpresa aquele mínimo temporal entre um antes e um depois irreversíveis, a tarefa de interpretá-la (KOSELLECK, 2001, p. 39). E, em um primeiro momento, a interpretação era feita por meio de uma proclamação. Aquele acontecimento era uma revolução; uma revolução que era a verdadeira emancipação política do Brasil; uma "revolução gloriosa" que fazia 
triunfar, finalmente, a Liberdade sobre a tirania. E as palavras finais da "Proclamação" reafirmavam:

Brasileiros! Já não devemos corar deste nome: a independência da nossa pátria, as suas leis vão ser desde este dia uma realidade. O maior obstáculo, que a isso se opunha, retira-se do meio de nós. [...] Tudo agora depende de nós mesmos, da nossa prudência, moderação e energia; continuemos como principiamos, e seremos apontados com admiração entre as nações mais cultas. Viva a nação brasileira! Viva a Constituição! Viva o Imperador constitucional, o senhor D. Pedro II.

Uma interpretação que não era exclusiva dos moderados, no momento em que se iniciava o Período Regencial. O jornal do boticário Ezequiel Corrêa dos Santos - Nova Luz Brasileira -, um dos principais arautos das idéias e proposições políticas e sociais dos Liberais exaltados - diria do mesmo acontecimento, em sua edição do dia 15 de abril de 1831:

\begin{abstract}
ABDICOU o tirano; e nas mãos da LIBERDADE existe hoje o cetro d'ouro que o monstro havia convertido em virga-férrea. Os Brasileiros começam finalmente a possuir uma PÁTRIA; e o Brasil vai-se querendo situar na América Livre. Legisladores! É chegado o tempo de estabeleceres a nossa Liberdade sobre bases menos frágeis; mais filosóficas e justas do que essas que regem a oprimida Europa. Em vossas mãos está hoje a felicidade presente do Povo brasileiro; e Ele espera dos seus escolhidos que se mostrem dignos da confiança que tem o Povo nos seus Representantes de 1831. (NOVA LUZ BRASILEIRA, 1831).
\end{abstract}

A interpretação daquela surpresa como uma revolução permitia a moderados e exaltados, naquele primeiro momento, pôr em evidência as idéias de Liberdade, Felicidade, Nação e Pátria brasileiras, assim como a de Povo, associando-as ao destino da América. 
Mas nem todos a interpretavam da mesma maneira. Para o alemão Carlos Seidler, que nas tropas mercenárias utilizadas pelo primeiro Pedro ocupava o posto de tenente do batalhão de Caçadores, o acontecimento do Sete de Abril possuía uma significação diversa. No relato rancoroso e preconceituoso que deixou de sua experiência americana, no qual D. Pedro I geralmente aparece como truculento e autoritário, a Abdicação - resultado de uma sedição militar - inaugurava para os brasileiros um período de incertezas e insegurança, sob o signo da revolução:

[No momento da Abdicação] os brasileiros sonhavam com um futuro de venturas, que supunham próximo, mas do qual ainda estavam muito distantes. O estourar dos foguetes e o amplo reboar das salvas de artilharia atraía novamente o povo disperso para o campo de St. Ana, cujo nome a canalha do Rio de Janeiro transformou no de Campo da Honra.

Ébrios de triunfo e cambaleando de alegria, bem como exaltada pelas bebidas alcoólicas a transitória loucura, contavam ali uns aos outros, do heroísmo brasileiro, do amor à liberdade e do 'espírito nacional que se erguia até as estrelas'. Na sua opinião não havia, no mundo inteiro, um povo maior nem mais poderoso, e cada mulato esfarrapado considerava-se um príncipe, porque, no seu bestunto, a afirmativa orgulhosa de: 'Eu sou brasileiro verdadeiro' o nobilitava. Mas infelizmente não houve distribuição de diplomas de patriotismo, incidentes isolados logo amarguraram o ruidoso júbilo e lançaram um manto sombrio de luto sobre a geral festividade.

Cenas de sangue, provocadas pelos portugueses, que ainda aderiam ao partido de seu compatriota, e promovidas com violência e em quantidades, derramaram gotas de fel na taça da alegria [...].

Estas pequenas cenas de horror deviam preceder a outras maiores para demonstrar aos brasileiros que, com a mudança de governo, nada haviam ganho e sim perdido muito. Os heróis da revolução, os homens do povo, mostravam-se, de dia a dia, cada vez mais arrogantes; o mérito de haverem expulsado um imperador era, na sua opinião, tamanho que a nação inteira jamais os poderia recompensar assaz gratamente. Eles mesmos, que expelido o tirano, transformavam-se agora em tiranos; a aristocracia agitava o cetro roubado. (SEIDLER, 1935, p. 209-215). 
Motins, rusgas, assuadas, ajuntamentos ilícitos, revoltas, sedições, insurreições e outros tipos de protestos sucediam-se nas ruas da Corte imperial e demais pontos do Império do Brasil. Delas participavam membros da boa sociedade, a plebe urbana e escravos, ampliando a sensação de insegurança e difundindo o medo. No relato de um estudioso,

[...] a Corte ainda sentia os efeitos do derradeiro levante exaltado de abril de 1832, quando o alarme das matracas voltou a soar pelas ruas no início da madrugada do dia 17 daquele mês. Desta vez, porém, os promotores de mais uma revolta que vinha sacudir a Capital do Império - a quinta desde a Abdicação e no espaço de apenas nove meses da primeira - eram egressos de uma outra facção, também de oposição, mas situada no extremo oposto do campo político regencial, que se preparavam para assumir a direção dos movimentos de rua deixada pelos exaltados: eram os emergentes caramurus, em sua primeira manifestação de força na cidade. (BASILE, 2004, p. 388).

Foi por essa época que Abreu e Lima retornou ao Império do Brasil. Ele fixou residência na capital do Império quando ainda corriam os processos não só contra os revoltosos de abril, mas também aqueles referentes às revoltas de setembro de 1832. A prisão do Barão de Bulow, um dos chefes da revolta de abril, só ocorreu em 24 de abril de 1833, e a condenação em novembro do mesmo ano, poucas semanas antes da destituição de José Bonifácio do cargo de Tutor imperial.

Na Corte, atraía-o, certamente, a Rua ou a praça pública ${ }^{20}$; a esta atribuiria sempre um duplo valor: ela possuía, certamente, o solo ideal para tornar frondosa a árvore da emancipação; mas nela também a anarquia possuía fortes raízes. Na capital do Império do Brasil, o General de Bolívar combateria mais com a pena do que com a espada, mas desta não abdicaria completamente.

Desde logo, sua interpretação do Sete de Abril divergiria também daquela de moderados e exaltados. Abreu e Lima não tinha dúvidas: a revolução do Sete de Abril

\footnotetext{
${ }^{20}$ A respeito dos espaços do Estado, da Casa e da Rua, cf. Mattos (2003, p. 122-141), especialmente o capítulo "Um império e três mundos".
} 
representara "uma verdadeira calamidade para o Brasil". Em diferentes oportunidades ele afirmaria que ela propiciara "o triunfo da demagogia sobre a realeza".

Em meio a tal quadro, ele estava disposto a cumprir o que dissera aos irmãos em carta redigida ainda na Filadélfia: empregar a espada "na conservação dos imprescritíveis direitos de meus cidadãos"; caso chegasse a desembainhá-la, não tornaria a embainhá-la "sem ter cumprido o meu dever". Também agora tinha a confiança de que poderia "cortar a raiz venenosa das revoluções que tantos renovos vai brotando no Brasil”.

Mas não somente pelo uso da espada. Esgrimindo a pena ele também imaginava prosseguir sua trajetória emancipacionista. A palavra escrita e impressa - sob a forma de jornais e de livros - era um modo de estar também na praça pública, com a intenção de preservar a ordem, garantir a integridade territorial do Império e constituir os brasileiros.

Todavia, a todas essas intenções algo se sobrepunha, com a marca da urgência: a obtenção da cidadania brasileira. Para tanto, encaminhou ao Governo regencial o pedido de reconhecimento da cidadania brasileira, do título de general e das condecorações que recebera no exterior. Uma reivindicação que, imediatamente, provocou reações contrárias.

A 28 de outubro de 1832, um ato da Regência garantia a "José Lima" os direitos civis, reconhecia todos os títulos e honras conferidos pelos governos da Colômbia e da Venezuela, assim como o título de General.

A Regência, em nome do Imperador o Senhor D. Pedro Segundo, há por bem sancionar e mandar que se execute a seguinte Resolução da Assembléia Legislativa.

Artigo único. José Lima, natural da província de Pernambuco, está no gozo dos Direitos de Cidadão.

A Assembléia Geral acolhera o parecer da Comissão de Constituição que sustentava ser legal aquela devolução porque o solicitante teria entrado "no serviço da Venezuela, antes 
de ser proclamada a independência do Brasil, e por conseqüência muito antes da Lei Fundamental do Império" que reconhecia títulos e honrarias (BERNARDES, 1978, p. 77-78).

Reintegrado à sociedade imperial, "José Lima" viveria até o seu falecimento do que lhe proporcionaria seus escritos e da parte que lhe coubera quando da devolução dos bens da família. Não abandonaria, porém, a praça pública.

O retorno à capital do Império seria assinalado pela imediata publicação de um periódico: Torre de Babel. O título escolhido era não apenas sugestivo, como também destacava fortemente o vínculo que seu redator, de modo consciente ou não, tecia entre uma experiência que mal terminara e outra que apenas começava. Torre de Babel era o título do periódico que editara recentemente em Cartagena, e por meio do qual travara acirrada discussão com os adversários de Bolívar no momento em que ocorria a repartição do Estado e do território que ajudara a formar e à qual se opunha. Um dos biógrafos de Abreu e Lima, Argeu Guimarães (1926), sustenta que a Torre de Cartagena, publicada em 1831, foi "o panfleto mais característico da combatividade do brasileiro" quando no exílio.

A Torre de Babel que circulou no Rio de Janeiro vinha à público custeada em parte pelo próprio redator, em parte por subscrições; mas podia ser adquirida também mediante uma assinatura trimestral ou em números avulsos nas tipografias de Ogier e Plancher, localizadas na rua do Ouvidor. Tanto a Torre de Babel como os demais jornais que Abreu e Lima editou no Rio de Janeiro guardavam as características de um pasquim; enquadram-se também no que um historiador denominou de "jornais de opinião". ${ }^{21}$ De uma forma ou de outra, disputavam todos a direção de uma expansão para dentro que apenas tinha início.

Não era a primeira vez e não seria a última que o Abreu e Lima redator de periódicos, aqui ou no exterior, recorreria a temas e expressões bíblicas, assim como a outros tantos recolhidos na mitologia clássica, para denominar suas publicações. O recurso a uma formulação alegórica ${ }^{22}$ ajudava em sua busca de aproximação com o público-leitor que

\footnotetext{
${ }^{21}$ Sobre os pasquins, cf. Sodré (1966); a respeito dos “jornais de opinião", cf. Morel e Barros (2003).

${ }^{22}$ Cf. "A leitura: uma prática cultural. Debate entre Pierre Boudieu e Roger Chartier". In: CHARTIER, Roger (Org.). Práticas da leitura. São Paulo: Estação Liberdade, 1996, p. 231-253.
} 
procurava conquistar, de modo muito semelhante aos "catecismos cívicos" que proliferavam no Rio de Janeiro desde a época da emancipação política, os quais recorrendo ao método de perguntas e respostas típicas dos catecismos religiosos para a doutrinação religiosa, tinham por finalidade iniciar os novos cidadãos no universo da cultura política do constitucionalismo.

Como em Cartagena, o redator dizia ter percebido, ao chegar ao Rio de Janeiro e ao Brasil, "tanto idioma diferente, tanta linguagem discordante, tanto dialeto inteligível", os quais resultavam das ambições e interesses políticos imoderados, e não das diferentes "nações" que habitavam a cidade:

[...] esta confusão nasce de alguma arrogância, que Deus quis castigar fazendo com que os homens não se entendam e caiam dispersos por esse novo mundo, que não é pequeno, ou pelo menos maior do que o mundo da Gênesis. Este é o motivo do nome. (TORRE DE BABEL, 9. jan.1833).

E, de modo irônico, acrescentava ter tido como uma "única razão" para participar da "moda de publicar periódicos", em voga na cidade, querer - à maneira dos outros redatores "[...] também a custa do público, moer-lhe a paciência. Pobre público" (TORRE DE BABEL, 9. jan. 1833).

Todavia, os sete números do periódico, dos quais cinco foram publicados no mês de janeiro e apenas dois em março de 1833, revelariam que os objetivos e intenções do redator eram muito mais amplos. E, por essa razão, eles se reproduziriam nas publicações que se seguiriam, sob a forma de periódicos ou não, revelando uma continuidade de princípios e pressupostos que reafirmavam um mesmo projeto.

Na interpretação contida nas páginas da Torre, "a abdicação tinha causado um estremecimento político no Brasil". Urgia, pois, debelar a anarquia e o perigo de uma guerra civil; preservar a integridade territorial do Império; e assegurar a continuidade da monarquia constitucional e unitária. Era urgente, também, combater as idéias, opiniões e ações políticas dos moderados, assim como a dos exaltados, propiciadoras de uma situação que comprometia 
a obra da emancipação; idéias e opiniões veiculadas por meio de folhas como a Aurora fluminense, A Verdade, o Independente, O Brasileiro e O Sete de abril. Tornava-se necessário dizer publicamente que o Governo regencial era refém da tirania:

\begin{abstract}
A tirania, esta menina, somos nós quem a estamos amamentando desde 1824; o ex-Imperador não a levou consigo. [...] A Regência podia tê-la morta se quisesse; porém com medo de tocá-la, deixou que botasse as unhas de fora; agora é tarde. O governo atual, sem atribuições nenhuma, ligado de pés e mãos, não pode ser tirânico nem arbitrário, nem útil baixo nenhum aspecto; com medo da tirania do governo, caímos na impotência legal, que é a mãe da pior das tiranias, a tirania de muitos; [tornara-se um governo] débil, insubsistente e fraco; e tão fraco que ele conhece a sua fraqueza. [...] Existirá enquanto não houver quem lhe diga: saia daí (TORRE DE BABEL, 16 jan.1833).
\end{abstract}

No artigo "Liberdade", no mesmo número, argumentava:

Esta palavra é mágica e tem a propriedade de, invocando-a, fazer do branco negro e do negro branco. Assim é que temos visto e estamos vendo a alguns malvados tornarem-se virtuosos, só porque tomam por estribilho esta palavra; outros, ladrões de profissão, tornaram-se homens de bem pela mesma razão; outros, entrampados até os narizes, pagam as suas dívidas com um lindo episódio sobre a Liberdade; outros, ambiciosos a toda prova, chamarem-se seu amigo, e tacham de tirania até os dez mandamentos, só porque não foram eles que os fizeram; enfim... Não há mais liberdade, se não ver como escaparmos da tormenta que nos ameaça.

Naquele ano de 1833, preocupavam-no, sobremaneira, as discussões a respeito da reforma da Carta de 1824, travadas na Assembléia Geral e também na praça pública. Ele rechaçava com veemência as propostas preconizadas por moderados e exaltados. De seu posicionamento, assim como daqueles que com ele concordavam, resultaria a acusação de 
serem os restauradores ou caramurus anti-reformistas; não obstante, eles preconizavam reformas de outra natureza:

Chamam-se Caramurus anti-reformistas os que se opõem à treta conhecida das anti-reformas, como à monarquia federativa, à vitaliciedade do Senado, à supressão do Poder Moderador, etc.; [...] aqueles que desejam as únicas reformas úteis e necessárias, como um poder municipal mais amplo, uma nova organização fiscal, uma polícia mais ativa, regulamento de Alfândegas, supressão de muitos empregos inúteis, destruição da moeda falsa, sistema no meio circulante; seguridade individual e uma completa organização do poder judicial [...] Desta sorte, confundindo as reformas puramente necessárias e práticas com as reformas especulativas e de nenhuma utilidade, nos querem fazer persuadir que somos anti-reformistas. (TORRE DE BABEL, 6 mar 1833).

Ele estigmatizava ainda a tentativa de golpe de Estado de 30 de julho de 1832, promovido pelos moderados. Não obstante o seu fracasso, aquela tentativa contribuíra para o descrédito das instituições, o enfraquecimento da administração e o comprometimento dos princípios legais que, de modo até certo ponto irônico, os moderados insistiam em dizer que sustentavam. "Quando o respeito que se deve aos Magistrados se converte em desdém e em mofa, adeus governo e adeus legalidade", advertia Abreu e Lima.

A Torre de Babel propunha-se a combater tudo isso; e, antes de tudo, propunha-se a esclarecer a opinião pública que se manifestava de modo incomum naqueles anos de "triunfo da Ação". Para o seu redator, o 7 de abril não fora nada mais do que uma sedição militar - “o 7 de abril não foi uma revolução, foi uma sedição militar que afrouxou as molas da moral pública”. Se ele desencadeou uma revolução, esta, “[...] entregue a si mesma se paralisou, ficou estacionária" (TORRE DE BABEL, 16 jan.1833). E daí resultava o avanço da anarquia, especialmente nas províncias "excitadas pela sedição do 7 de abril", como acontecera na Colômbia em passado recente. 
O governo está numa posição falsa; um transtorno nas províncias do norte pode trazer a dissolução do Império, e qualquer acontecimento, por pequeno que seja, pode produzir a guerra civil, de cuja marcha ninguém poderá lavar a Regência nem o atual Ministério. Embora ninguém me faça caso, não me ressentirei do desprezo, porque serei vingado pelos sucessos que anuncio. (TORRE DE BABEL, 12 jan. 1833).

Ele julgava ser papel do jornal que redigia chamar a atenção dos leitores para o fato de alguns acreditarem ser possível impedir a dissolução do Império a partir da idéia de se viabilizar a separação das províncias do Norte, à exceção dos ricos que seriam aceitos no outro Estado situado ao Sul, dirigido por um governo central mais rigoroso. Era preciso dizer aos cidadãos do Império e aos súditos do imperador ainda menino ser tudo isso um grave equívoco:

Tudo isso é asneira, tudo isso é tão falso quanto o 7 de abril; tudo isso é efêmero, é irrealizável, No momento em que se abandone a idéia de o Império do Brasil reunido como estava a dissolução será total, e só com uma mão poderosa poderia soldar esta peça, se chegasse a quebrar-se algum dia.

E argumentava também por meio de uma comparação, conclamando os seus leitores a lançarem os olhos sobre as repúblicas vizinhas, no intuito de entenderem o que escapava à acuidade dos "nossos políticos":

[...] vejamos a Buenos Aires com 500 mil habitantes divididos em pequenos Estados, que são hoje patrimônios de outros tanto régulos; e deste exemplo bem palpável deduzamos a consequiência necessária da nossa posição delicada.

Ora, também nesta oportunidade o conhecimento do que ocorria em um outro ponto da América no momento de organização dos novos corpos políticos surgidos da emancipação política, era propiciado pela leitura de uma publicação local - a Torre de Babel, no caso -, e 
não pela leitura de um jornal da localidade onde ocorrera o evento - Buenos Aires; um conhecimento ou informação que se dava "tempos depois", e não simultaneamente ao evento de que se falava; e daí resultava, como destaca B. Anderson $(1989, \text { p. } 74)^{23}$ com argúcia, que aqueles que eram informados no Rio de Janeiro concluíam que a experiência que viviam era "semelhante" à ocorrida em Buenos Aires, e não que "fazia parte" dela. De modo inverso, os acontecimentos das diferentes províncias do Império "faziam parte" da experiência vivida no Rio de Janeiro, porque, neste particular, eram vividas como experiências simultâneas, contribuindo, assim, para a construção imaginária de uma mesma comunidade - o Império do Brasil. E, conseqüentemente, para a construção da consciência da necessidade de sua preservação.

Por meio das páginas da Torre de Babel, Abreu e Lima não se furtava de indicar as soluções para os problemas enfrentados pelo novo país, a primeira delas consistindo evidentemente no afastamento dos responsáveis pelo governo regencial. "Saia daí”, ele já dissera, quase ordenara, aos que julgava serem responsáveis por aquele estado de coisas em um dos primeiros números do jornal, de modo a pôr em destaque a necessidade de uma autoridade que restaurasse a ordem. Ao mesmo tempo, de modo a restaurar a figura do primeiro imperador, insistia em proclamar que D. Pedro I já havia pensado em abdicar, tendo apenas antecipado sua decisão. Tentava demonstrar, assim, que a abdicação fora uma decisão do imperador, e não o resultado de um ato de força; a atitude de D. Pedro I fora um ato a favor do povo brasileiro. De outra parte, o reinado de D. Pedro I não podia, a seu ver, ser adjetivado de tirânico e despótico:

Não é por aí que pecou o governo do ex-Imperador, nem será desse pé que se cocheará a Regência; as suas faltas mais notáveis foram o desmazelo, a in-administração, o peculato, os afilhados, a imoralidade nos agentes do poder, a falta de energia na ação das leis, a impunidade dos crimes, a profusão dos dinheiros públicos, finalmente as bagatelas em vez das coisas úteis (TORRE DE BABEL, 16 jan.1833).

\footnotetext{
${ }^{23}$ A respeito, cf. também o interessante artigo de Jorge Myers (2003, p. 39-63).
} 
À autoridade deveria somar-se uma administração que empreendesse reformas efetivas, como, por exemplo, o impulso ao comércio de cabotagem, o fortalecimento da polícia das grandes cidades, a criação da polícia rural, a eliminação do "o abuso das oficinas públicas em que cada oficial é um sultão", a difusão da instrução primária e a criação de um Ministério somente para os negócios da instrução pública. (TORRE DE BABEL, 6 mar.1833).

Em edição anterior ( 25 de janeiro), a questão da educação já merecera a sua atenção. Para ele, ela permanecia guardando entre os brasileiros, muito dos "ressábios do antigo regime". Reinava na sociedade imperial a crença de que a educação era privilégio de uma "certa classe privilegiada", que tinha o direito de viver em um colégio e receber alguns "elementos de civilização com uma rotina mui grosseira". Os jovens se graduavam apenas como advogados ou como clérigos, "de sorte que todo e qualquer benefício que não seja o foro ou altar, não se reputa educação". Assim sendo, havia um número expressivo de "maus advogados e juízes", os quais acaso tivessem recebido outra educação poderiam ter sido "excelentes pintores, ourives, ferreiros, etc". Por sua vez, a "má educação" oferecida "à classe de clérigos mui ignorantes, e alguns não muito católicos", impossibilitou a formação de "insígnios matemáticos, excelentes físicos, exímios naturalistas". Como nenhuma nação pode contar apenas com advogados e clérigos, e como a educação é oferecida apenas para um segmento restrito da população, o redator da Torre de Babel levava seus leitores a concluírem que

[...] a massa da nossa população fica toda sem educação, e por consequiência sem costumes. Eu quisera que víssemos outros povos, onde há classes, para que aprendessemos a maneira de dar uma educação proporcionada a todo mundo. Cremos que com ter uma universidade em cada Província esta tudo feito; sem lembrarmo-nos de que somente uma educação elementar é o que nos pode salvar. Como queremos leis sem costumes? Como queremos costumes sem educação? Onde está uma escola de moral cristã? Uma educação racional como nos Estados Unidos compreendida entre indústria e a moral seria suficiente para melhorar os nossos costumes, ainda que tivéssemos poucos teólogos e menos advogados. 
Preconizava, assim, uma educação elementar para o conjunto dos homens livres, ou seja, para todos aqueles que não fossem escravos. Em suas próprias palavras, o "entrecruzamento de classes", a "liberdade de escravos", a "primazia de cores", a "igualdade de fato" - "tudo se tem imaginado para pôr em guerra a metade do nosso povo com a outra metade". E indaga a respeito da razão de haver "muita gente com medo da gente cor", e do costume de se "colocar homens de cor livres entre os da mesma espécie escravos".

[...] A escravidão é um ferrete de ignomínia porque traz consigo a degradação da espécie, mas cor é um acidente. - Não é a cor que produz rivalidade entre as classes, é a lembrança de sua origem servil; sem embargo, isto era bem considerado em Roma e Grécia, onde os libertos não gozavam de direitos políticos nem civis [...] no Brasil onde os libertos são cidadãos, onde o escravo mesmo é pessoa, e tem direitos que reclamar contra o seu próprio senhor, que há que temer de cidadãos em tudo iguais em direitos, iguais em garantias e em gozos? (TORRE DE BABEL, 12 jan.1833).

A defesa de Dom Pedro I nas páginas do jornal contribuiria para ampliar a identificação que os opositores de Abreu e Lima dele faziam com os caramurus ou restauradores. E o redator da Torre de Babel não se esquivaria da acusação; parecia mesmo querer demonstrar coerência com a opinião que externara em carta dirigida a Santander sobre o melhor regime político para garantir a ordem monárquica constitucional e a integridade territorial do país, associando-o à figura e à obra do ex-imperador. E se tal não deixava de espantar a alguns contemporâneos, surpreende, ainda hoje, a muitos de seus biógrafos, pois, como comentou Velho Sobrinho (1937, p. 39), é algo "que admira num ilustrado e distinto general que batalhou em favor das repúblicas.".

Em plena praça pública, o General de Bolívar buscava esclarecer seus leitores a respeito da polissemia das denominações "restaurador" e "caramuru", ignorada pelos adversários. E começava por dizer que 
"são restauradores todos aqueles que não são frades do Convento da Moderação ou não rezam pelo breviário da Aurora ou da Verdade". (TORRE DE BABEL, 12 jan.1833).

E prosseguia, na mesma edição do jornal, fustigando ainda mais os moderados, recordando os diferentes motivos que levavam um cidadão a ser um restaurador. Dentre outros, enumerava a oposição a Feijó, a Vasconcelos e seus companheiros; desejar uma nova lei de anistia, uma polícia mais eficaz e a permanência do tutor; a atitude de respeito por D. Pedro de Alcântara e por D. Pedro I. Em sua opinião, era preciso tornar claro que,

[...] há restauradores passivos e ativos; os primeiros são aqueles que desejam a volta do Imperador como um dique contra as calamidades públicas; este número não é pequeno; os segundos são os que trabalham para sua volta ao trono, estes são muito poucos - a Nação toda deseja a permanência do príncipe brasileiro; uma mudança agora ofenderia a sua nacionalidade; um monarca nascido deste lado do Atlântico satisfaz em muito a ambição dos brasileiros; nem Deus me faria crer que haja quem deseje ou trabalhe para destronar um filho, que sucedeu a seu pai por um ato de voluntária abdicação - um fato semelhante seria único na história e nos cobriria de opróbrio: faço pois mais justiça aos brasileiros.

No que viria a ser o penúltimo exemplar do periódico, publicado no dia 2 de março, Abreu e Lima tornava explícitos os motivos que o levaram a se tornar um caramuru. E mais do que isso: se os moderados e exaltados insistiam em afirmar que a seita dos caramurus era "uma espécie de maçonaria", ele responde por meio da criação de um "catecismo da Caramururaria" e da "ordem Caramurônica", a qual, como a ordem maçônica, estava dividida em graus. A transcrição é longa, mas certamente possibilitará tornar mais claro o lugar no conjunto dos caramurus daquele que continuava a ter a seu lado um companheiro inseparável:

Primeiro grau - São todos aqueles que desejam que o Duque de Bragança volte ao Brasil, ponha o filho no berço, tire-lhe a coroa que pesa muito para uma criança, ponha-a sobre a sua cabeça. [...] Estes são muito poucos; 
apenas trabalham na pedra bruta e por isso são chamados Caramurus brutos. $[\ldots]$

Segundo grau - São aqueles que desejam que volte D Pedro, e que se encarregue da Regência como o parente mais imediato do Imperador, em virtude da constituição do Império; que reviva a Corte e o luxo. [...] Estes são mais numerosos que os primeiros [sic] pequeno ainda, trabalham na pedra lavrada, e por isso são chamados Caramurus. [sic].

Terceiro grau - São aqueles que desejam o mesmo, que os do segundo grau; porém sem Corte, sem luxo, sem exército; sem forçar (sic) e sem prêmios. [...] Esses trabalham em pedra fina, e por isso - são chamados Caramurus perfeitos.

Quarto grau - São aqueles que sem desejar que D Pedro volte à ser imperador, nem regente, querem contudo que não o proscrevam; que o recebamos, se volta como um hóspede nacional, com os braços abertos, que lhe perdoemos, não o que ele fez, senão o que deixou de fazer em bem do Brasil; que o consideremos como um homem, cujo nome preenche o artigo $4^{\mathrm{o}}$ da Constituição do Estado. Estes trabalham em ferro, e por isso são chamados Caramurus Ilustres.

Quinto grau - São aqueles que sem querer que D. Pedro volte ao Brasil, desejam que falem bem dele; que o respeitem como Criador do Império, como o Sustentador da Integridade Nacional; como Pai do Imperador; como um Príncipe Liberal, que deu duas cartas de alforria a dois povos escravos. Estes trabalham em prata e por isso são chamados Caramurus Excelentes. Sexto grau - São aqueles que não desejam, nem querem que D Pedro volte; nem querem que falem bem dele; porque com justiça não o merece; ele foi quem nos meteu neste cipoal, e depois bateu asas e voou; [...] porém, ao mesmo tempo, não julgam racional nem moral que o insultem, que o vituperem [...] sem lembrarmo-nos que tudo quanto digamos do Pai recai sobre o filho. Estes trabalham em ouro, e por isso são chamados Caramurus Sublimes.

Sétimo e último grau - São todos aqueles que, abstração feita a D. Pedro, desejam a felicidade de sua pátria; desejam a integridade do Império, se gloriam de ter um Príncipe nascido no Brasil como primeiro Magistrado da Nação; querem um governo legal, firme e desinteressado; [...] porém não querem remendar uma constituição nova só pelo gosto de dar Pai a cada 
criança; isto é, a cada remendo querem inviolabilidade da pessoa e bens; querem finalmente Governantes e Governados, porém não intrigantes e intrigados. Estes são infinitos, trabalham em diamante e por isso são chamados Caramurus Sábios.

Colocando-se ao lado dos "infinitos" caramurus que "trabalham em diamante" - os Caramurus Sábios -, Abreu e Lima não perdia de vista a longa experiência vivida ao lado do Libertador. Mais do que nunca, comparava o que estava acontecendo no Império do Brasil ao que acontecera na Gran-Colômbia; mais do que nunca associava a figura daquele que promovera a emancipação política do Império do Brasil à figura de Bolívar.

No seu entender, somente um governo forte, dotado de instrumentos centralizadores, poderia preservar a ordem; somente a ordem poderia fundar e garantir a independência do Império do Brasil e a liberdade dos súditos e cidadãos brasileiros. Os "infinitos" caramurus aos quais se somavam aqueles do quarto ao sexto graus da "ordem Caramurônica" - não defendiam o retorno de D. Pedro I ao governo do Império; defendiam, sim, a retomada da obra que ele iniciara em 1822, e que as circunstâncias fizeram com que se perdesse por um momento. Nela, o Imperador assumia o papel de um árbitro soberano entre os que, por meio de discursos e práticas diversos e divergentes, que tendiam à radicalização, no âmbito do governo do Estado, nas casas e na praça pública, tinham por objetivo fazer triunfar um projeto determinado no momento de organização de um novo corpo político.

As opiniões veiculadas pelas páginas do jornal de Abreu e Lima seriam vivamente contestadas por outras publicações do período, as quais se serviram de contundência semelhante e, por vezes, ainda maior. Exemplifica-o a Aurora Fluminense, o jornal moderado de Evaristo da Veiga.

Na edição de 15 de fevereiro de 1833, Evaristo da Veiga publicava um artigo criticando os pronunciamentos "das facções descontentes" com as eleições para Juiz de Paz nas freguesias de Santa Rita, Candelária e Engenho Velho. Ao defender a idoneidade dos "homens respeitados nas suas freguesias", cujos nomes compunham a lista dos que os 
moderados pretendiam tornar juízes de paz, Evaristo da Veiga aproveitava para atacar os caramurus. E, de modo irônico, recordava constarem da lista, por acaso, nomes como "o de um aventureiro Roma, disfarçado com o pomposo título de General Lima.” (AURORA FLUMINENSE, 1833, n. 735, p. 3.137-3.138). A resposta de Abreu e Lima, que não se fez esperar, propiciou ao redator d'Aurora um segundo artigo contra aquele que considerava um "aventureiro".

Um homem que foi capitão ao serviço do Brasil, que insiste em querer ter o nome de General Lima, e que nos fala em tom de Napoleão, nos cem combates que o imortalizaram em Colômbia, encheu contra nós quatro páginas de injúrias e ameaças. O nosso crime é dizer que ele é o aventureiro Roma, disfarçado sob o pomposo título de General Lima. Não disputaremos agora sobre o nome de Roma, ou de Lima, e concederemos que o primeiro foi uma alcunha, mas quanto à qualidade de aventureiro, quem pode recusála ao indivíduo que, preso e criminoso, abandonou o seu país para buscar serviço em uma terra estrangeira, e que, regressando daí, tenta todos os meios de tornar-se famoso no Brasil, ainda que não seja derramando virulentos insultos contra pessoas que ele julga expostas ao ódio de um partido numeroso e audaz? Os seus cem combates, quando tinham na realidade existido, não o isentam desse epíteto. Mas ainda sujeitos há que duvidam de tanta façanha, e que recorrendo às páginas da história da Colômbia, asseveram não achar aí o nome do General Lima. O Libertador da Venezuela, e da Nova Granada, o vencedor em Boyacá, em Porto Cabello, em Carabobo. [...] Nós sabemos perfeitamente que o nosso contendor o que procura, é fazer-se célebre, a fim de ser chamado a representar um papel na cena tumultuada do Brasil. Este pensamento tem presidido todos os atos e palavras do Sr. Lima, dês que aqui chegou, e conhecendo a tendência de certos espíritos na Capital, se mostrou apologista, e apaixonado do ex-Imperador.

Mas Evaristo da Veiga não se deteria aí, nem moderaria o tom. Nas edições de 27 de fevereiro e $1^{\circ}$ de março voltaria a atacar o "aventureiro Roma", buscando apresentar aquele que caracterizava também como um impostor como defensor do retorno do ex-imperador ao 
trono do Império do Brasil. No terceiro artigo, uma longa passagem oferece subsídios para compreender como eram vistos por parcela significativa dos contemporâneos quer a militância de Abreu e Lima, quer a sua trajetória de vida.

Esse general [...] diz que esteve 15 anos proscrito, por ser filho de um mártir. Quando, em 1822, o Brasil lutava pela sua independência, e as portas do templo da liberdade haviam sido abertas a todos os proscritos, presos e perseguidos por opiniões políticas; o que impediu o Sr. Abreu e Lima de regressar ao seu país, para aí empregar sua façanhosa espada em prol dos direitos dele? Mas então, estava o general ocupado no serviço de Bolívar, por cuja morte, entendendo não fazer fortuna em Colômbia, se retirou, e sabendo na Europa que o Brasil se achava exposto aos choques que sucedem sempre uma revolução, avaliou o ensejo como favorável para vir aqui representar o seu papel. Como aventureiro ou como fera procura ele atiçar entre nós o fogo da discórdia, torna-se paladino da honra e glória de D. Pedro I, e lança-se, ao menor pretexto, sobre o cidadão mais exposto para assim adquirir um nome. Vendo que a sua primeira Carta publicada no momento que as paixões se exasperavam, produzira uma espécie de escândalo, publica segunda, para repetir os mesmos insultos, as mesmas arrieiradas [...] Acredita-se um ator famoso no drama político, supõe que lhe é fácil mover as massas, fazer apelos ao povo, e que a um assobio seu a multidão o acompanhará a qualquer sítio que queira.

Inflamando-lhe a imaginação, verdadeiro D. Quixote, ele vê à sua voz encher-se de gente o campo da Aclamação, para decidir aí sua contenda com a Aurora; fantasia deliberações em comício, bem como o outro via em todas as partes castelos e gigantes; sonha com a sombra de seu pai (que a ter conservado os sentimentos que nutria em sua alma no ano de 1817 , hoje o amaldiçoaria, como a um satélite de D Pedro I e um restaurador), põe em sua boca discursos empáticos; e depois de haver assim esgotado o círculo mesquinho dos tropos e figuras que lhe ensinaram nas aulas que freqüentou, acredita haver feito milagres, e ter assombrado as massas. Nem ouve que the gritam de redor e de todos os lados - 'General, a vossa charlataneria não engana a pessoa alguma; quereis tornar necessária a vossa espada, julgais fazer-vos chefe de partido. (AURORA FLUMINENSE, 1833, n. 739, grifos do autor). 
Evaristo reproduziria ainda, no último artigo, uma passagem de antiga carta de Abreu e Lima a seus irmãos, acima já mencionada, com o propósito, talvez, de demonstrar tanto que o pernambucano retornava à Corte imperial com o propósito principal de desembainhar sua espada, quanto exorcizar de uma vez por todas quer o fantasma do republicanismo representado por Simon Bolívar quer o da restauração, encarnado em D. Pedro I. Ao transformar o "Aventureiro Roma" em um "General sem batalhas", o redator d'Aurora Fluminense dizia:

Estes extratos que o Sr.Abreu e Lima escreveu de Filadélfia a seus irmãos, Srs. Romas, em data de 12 de julho de 1831, descobrem a um tempo, o aventureiro e o rompente. Em primeiro lugar não é a favor da nação colombiana que ele estava; por sua própria confissão, servia a causa de um homem, achava-se ligado aos interesses e fortuna da pessoa de Bolívar. Morto Bolívar por quem faria mais sacrifícios? Depois nós o vemos apressar-se a vir ao Brasil tentar venturas, tendo sempre diante dos olhos a sua espada, que ele parece pronto a vender, como os Suíços, a quem mais der. Está muito longe do teatro do drama político, em que pretende representar um papel, e assim, não sabe ainda, o que lhe convém: é por isso que fala no ex-imperador, na Pátria, nos direito imprescritíveis, disposto a invocar qualquer destes nomes, segundo melhor lhe convier. Sobretudo aconselha seus irmãos que não tomem partido enquanto ele não chega: é preciso que o sigam, seja qual for a causa que abrace, e ele não pode abraçar nenhuma, sem chegar ao Brasil, sem ver aqui qual é o caminho que há de trilhar, qual é aquele que lhe proporciona maiores esperanças de agradecimento. Com esse objetivo diante dos olhos, o general, a princípio visitou, procurou, fez a corte aos Moderados; porém estes não empregaram a sua espada; ei-lo voltado para os caramurus conspiradores, que podem carecer mais de quem dê cutiladas. Não é este o caráter de um genuíno aventureiro? Ele mesmo se descreveu a si próprio, e de maneira tal que ninguém se enganasse com a sua pessoa. Quanto às rodomontadas, nós temos na carta de Julho, as batalhas, os sacrifícios, a reputação militar da América do Sul, a confiança na própria importância para decidir os negócios 
do Brasil e todas as circunstâncias em fim que têm feito dar ao Sr. Lima o nome de general sem batalhas. (AURORA FLUMINENSE, 1833, n. 740, p. $3.155-3.156)^{24}$.

Abreu e Lima talvez não duvidasse que, muito em breve, uma interdição partida do governo regencial poria fim à trajetória da Torre de Babel. E assim realmente aconteceu, em fins de março de 1833, caracterizando, por certo, a aproximação cada vez mais estreita entre moderados e exaltados, em face do que era apresentado como a ameaça restauradora, aproximação que culminaria na aprovação do Ato Adicional de 1834 - o pleno "triunfo da Ação”, na análise de J. J. da Rocha. Não por outro motivo, ainda em fevereiro daquele mesmo ano, o persistente, contundente, aguerrido e, por vezes, bufão, Abreu e Lima procurava se antecipar aos acontecimentos, lançando um novo periódico: Arca de Noé.

Foram vinte os números do novo periódico, que circularam com periodicidade irregular entre 12 de fevereiro e 5 de dezembro de 1833. Custeados quase sempre com recursos do próprio redator, eles foram impressos na Tipografia do Diário, no início, e na Tipografia Miranda e Carneiro, em seguida.

As idéias nela expostas não diferiam no fundamental do que era dito na Torre. $\mathrm{O}$ artigo intitulado "Prospecto", no número inicial, reafirmava a análise que o editor da nova folha sempre fizera da situação política do Império sob as Regências, pondo em relevo mais uma vez os perigos que rondavam o novo país: "nada menos que o flagelo da guerra civil", prenunciando "um Dilúvio de sangue que tem de inundar nossos campos e submergir nossas cidades". A mensagem era clara, desde o título da publicação: "como Noé se salvou do Dilúvio das águas com que Deus resolveu castigar, em bom tempo, a malícia dos homens" [...] "não será muito que outra Arca, com o mesmo nome, que lhe oferecemos nesta Folha, nos salve agora do Dilúvio de sangue, que nos está iminente, se nela com fé nos acolhermos" (ARCA DE NOÉ, 12 fev.1833). Por meio de uma analogia, a experiência do relato bíblico era associada às experiências históricas bolivariana e imperial, constituindo uma única "Arca", e

\footnotetext{
${ }^{24}$ A propósito das relações entre E. Veiga e Abreu e Lima. cf. Souza (1939).
} 
assim tanto possibilitando um diagnóstico, quanto ambas se apresentando como "mestras da vida" - "se nela com fé nos acolhermos"!

Um título - Arca de Noé - que se desdobrava enfaticamente na denominação escolhida para o artigo de abertura - "Prospecto". Ora, de acordo com os dicionaristas, um prospecto é tanto um pequeno impresso, "um programa no qual se anuncia e se dá uma idéia de uma obra, que se publica, de um estabelecimento ou empresa que se apresenta para servir à utilidade pública", no dizer ainda uma vez de Moraes e Silva, quanto "ver ao longe, até onde os olhos alcançam", isto é, em "prospectivo ou perspectiva". Ora, dizendo de outro modo, certamente mais direto, a nova Arca de Noé não se limitava a diagnosticar a partir de experiências vividas; ela diagnosticava como condição para realizar um prognóstico, do qual derivava uma alternativa para o futuro dos brasileiros, sob o comando firme do novo Noé "se nela com fé nos acolhermos"!

A seus leitores o editor oferecia, assim, uma nova folha - a nova "Arca da Aliança" cujo objetivo era congregar não apenas os diversos segmentos do povo caramurano, mas todo e qualquer cidadão que não se identificasse com as propostas defendidas por moderados e exaltados. Somente a nova Arca podia conter "os que têm opiniões opostas, assim como o lobo e o cordeiro", sob a liderança de alguém cuja longa experiência habilitava como timoneiro.

Em suas páginas, artigos versando sobre os mais variados assuntos, quer fossem eles eminentemente políticos ou simples comentários sobre a vida na cidade do Rio de Janeiro, serviam como pretexto ou gancho para o desenvolvimento de uma argumentação que procurava expor aos leitores as fraquezas e desmandos do governo regencial, assim como das facções políticas a que se opunha. Naquelas páginas tratava-se, como já acontecera no periódico anterior, da atuação dos partidos políticos, do poder da Igreja, das desavenças entre as províncias, da instrução dos cidadãos e de sua civilidade, assim como da produção literária entre nós; nada parecia lhe escapar. Mas, de modo quase invariável, quase todos os temas convergiam para a defesa dos ideais e princípios que deveriam reger a organização do Estado e da sociedade imperial naqueles anos conturbados da experiência regencial. Em suas páginas, 
ao lado do debate travado com outros periodistas, eram transcritas as cartas de seus leitores, reais ou imaginários.

Naquelas páginas também não deixavam de estar presentes temas e questões referentes aos militares e ao clero católico, cuja importância que até então haviam desfrutado contrastava com "a primazia da ordem civil" definida e defendida por aqueles que predominavam no governo regencial. Para o redator, a classe dos militares, após o 7 de abril, tinha sido "reduzida a uma obscura e degradante nulidade". Os militares haviam perdido a liberdade, não podendo externar suas opiniões. Diversa era a opinião a respeito das posições assumidas pelos representantes da Igreja no Brasil, abrangendo tanto críticas à nomeação de determinado bispo e aos projetos da Comissão Eclesiástica da Câmara, quanto a rejeição ao pagamento de taxas à Igreja e às regras que definiam quem poderia contrair matrimônio.

Como em a Torre de Babel, Arca de Noé não deixaria de suscitar oposições. Dela, todavia, não se ocuparia um Evaristo da Veiga. Ou mesmo o cônego Januário da Cunha Barbosa, cuja atuação política era marcante desde os tempos da emancipação política, e a quem Wanireh Chacon atribui a autoria de uma comédia - "A rusga da Praia Grande ou o quixotismo do general das massas" -, contra Abreu e Lima, no mesmo ano de sua volta ao Brasil, e da qual derivaria o apodo de "general das massas.",25

Em 16 de fevereiro, quatro dias após ter circulado na Corte o primeiro número da Arca, o periódico $\mathbf{O}$ Nacional, em sua $36^{\mathrm{a}}$ edição, publicou um artigo saudando um novo livro. O editor, José Maria do Amaral, saudava a obra de Antonio Muniz de Souza, Viagens ao interior do Brasil, que ainda se encontrava no prelo. Segundo ele, a leitura da obra era relevante tanto para os brasileiros quanto para os estrangeiros porque "mostra a riqueza do vasto terrão que habitamos, e por animar o desenvolvimento do gênio do Brasil". O desenrolar do artigo, porém, apresentava crítica às idéias defendidas por Abreu e Lima, em seus dois jornais.

\footnotetext{
25 "O escárnio de 'General das Massas' não foi inventado por Evaristo da Veiga; ele apenas retornou a comédia anônima do cônego Januário da Cunha Barbosa, 'A rusga da Praia Grande ou o quixotismo do general das massas', contra Abreu e Lima no mesmo ano de sua volta ao Brasil”. (CHACON, 1983, p. 157-158).
} 
Geralmente, e se pode dizer com justiça, se faz de nós o conceito que não sabemos apreciar as produções literárias e que unicamente entretidos com a fastidiosa política de que os nossos jornais diariamente se ocupam, não curamos de procurarmos aqueles meios de instrução que muito podem concorrer para sustentação da nossa liberdade. Com efeito, em dez anos de Independência poucas obras úteis tem aparecido; temos ocasião de promovêlas, não nos poupemos a isso, não sejamos caramurus, que só cultivam a retrogração. Depois da destruição da Torre de Babel, nada mais natural do que o Pai Noé aparecesse com sua Arca para receber toda espécie de animalejos que quisessem fugir do dilúvio, causado pela maldade e ambição dos edificadores da Torre; eis um passo da História Sagrada que a política tem aproveitado, talvez por ser manejada por bons cristãos. Apareceu com efeito a Arca do Pai Noé da parte dos Caramurus, o que é um sinal evidente de que eles já se receiam da destruição, e começam a preparar-se para salvarse do desinteresse político; eis tácita (ilegível) pelos caramurus da sua fraqueza, e falta de esperança pela vitória. Dizem que o autor da Arca é o mesmo que caiu com a Torre que concebendo grande medo da queda se pôs fechado na Arca para evitar alguma outra desgraça; se assim for, é um dos casos mais galantes o termos de admirar el general feito piloto depois de ter sido sineiro.

E concluía dizendo esperar ser factível a continuação da edição da Arca, porque dependendo do furor das forças da natureza ela poderia se manter ou submergir para fora do dilúvio. E acrescentava lembrando que, se Abreu e Lima fazia duras críticas à capacidade intelectual daqueles que lidavam com a palavra impressa no Brasil, tanto pela falta de sensibilidade em relação à produção literária como pelo interesse extremo com as questões políticas, deveria, antes de tudo, reconhecer o caráter retrógrado dos caramurus, ou seja, dele próprio. Se era fato que após a independência "poucas obras úteis" haviam sido produzidas, nada era mais grave do que só saber cultivar a retrogradação. A Arca nada mais era que o túmulo político dos caramurus e, Abreu e Lima, por sua vez, era um retornado, general fanfarrão e bisonho, que se mostrava piloto medroso de uma nau desgovernada. 
A resposta do "general das massas" a essa e outras críticas não se fez demorar. Um mês após a publicação do artigo em $\mathbf{O}$ Nacional, o jornalista pernambucano publicava, no penúltimo número da Torre, o "catecismo da caramuraria”, como já foi visto.

Em 1835, Abreu e Lima teria editado um novo jornal: o Mensageiro Niteroiense. ${ }^{26}$ Dos artigos ali publicados, e de outros inéditos, escritos no calor dos acontecimentos daqueles anos, resultou a edição de Bosquejo histórico, político e literário do Brasil, naquele mesmo ano.

Em “defesa da união do Brasil sob o governo monárquico constitucional. Contra a dissolução do país", Abreu e Lima lançava um novo periódico, no início de 1836. A ele deu o nome de Raio de Júpiter.

É bastante provável que, então, muitos daqueles homens e mulheres que habitavam o Império do Brasil, particularmente os que pertenciam à boa sociedade, soubessem ser Júpiter a maior divindade do Olimpo. Aquele que na mitologia grega era identificado como Zeus tivera uma trajetória atribulada, desde o seu nascimento. Então, sua mãe Cibele fora obrigado a escondê-lo do próprio pai, Saturno, para que não fosse devorado, como já acontecera com os outros filhos. Tendo crescido e adquirido toda a sua força divina, conseguira por meio de um artifício que o pai vomitasse seus irmãos - Netuno e Plutão. Da vitória na luta que, durante dez anos, os três irmãos travaram contra o próprio pai e os Titãs, resultou a repartição entre si do universo, cabendo a Júpiter o domínio do céu e da terra. Após outras vitórias dos três irmãos olímpicos, consolidou-se o poder de Júpiter. Concebido inicialmente como divindade do céu e dos fenômenos atmosféricos, pouco a pouco adquiriu o caráter de deus supremo, imagem da justiça e da razão, da ordem e da autoridade. Onipotente, tudo vê e sabe, possuindo o dom de prever o futuro. Júpiter ou Zeus era comumente representado com traços

\footnotetext{
${ }^{26}$ A partir das informações contidas nas obras de alguns biógrafos de Abreu e Lima, tentei localizar algum número de Mensageiro Niteroiense, na seção de Obras Raras da Biblioteca Nacional, assim como em outras instituições. O esforço resultou vão. Todavia, parte significativa dos textos do jornal, se não todos, foi reproduzida em Bosquejo.
} 
de homem maduro, robusto, de semblante grave e majestoso, coroado por folhas de carvalho. Seus atributos são o raio, o cetro e a águia. ${ }^{27}$

Por meio dos vinte e cinco números do novo jornal, editados entre 8 de fevereiro e 3 de maio de 1836, um Abreu e Lima já homem maduro, de semblante grave e majestoso, talvez, prosseguia sua missão de cunho também pedagógico de alertar e instruir os brasileiros a respeito dos perigos a que estavam expostos; uma missão que, no seu entender, sustentavase em sua capacidade de prever um futuro de incertezas a partir das experiências vividas, as quais lhe possibilitavam ver e saber. Mas um futuro que poderia ser diferente: das páginas do novo jornal, como um raio, justiça, razão, ordem e autoridade eram apresentadas aos leitores como princípios a serem preservados e um fim a ser alcançado, uma vez combatidos os elementos que as estorvavam.

Ali, de modo eloqüente e incansável reafirmava "Nossa fé", título que dera ao artigo do número inaugural:

A monarquia é o nosso credo, e somos monarquistas por educação, hábitos e princípios; e o somos também porque (graças a Deus), temos senso comum e mais boa fé do que todos aqueles que se dizem republicanos.

A desorganização e a anarquia que grassavam tanto na Corte quanto nas províncias do Império colocavam em risco a Monarquia e a unidade territorial, no seu entender. Elas eram alimentadas, agora, pelo novo regente, o padre Diogo Antonio Feijó, eleito no ano anterior, de acordo com as novas determinações do Ato Adicional de 1834. Somente o apoio de Evaristo da Veiga garantira a Feijó sua eleição, mas tal apoio não era suficiente para evitar os descontentamentos e críticas crescentes. O Raio de Júpiter tinha como uma de suas missões alertar os brasileiros a respeito do que ocorria.

Em "Um alarma para o Brasil”, artigo publicado no segundo número do periódico, que circulou apenas três dias após o primeiro, o redator contestava a reforma do artigo 123 da

\footnotetext{
${ }^{27}$ Para esses dados, cf. Dicionário de mitologia greco-romana. São Paulo: Abril Cultura, 1973, p.103.
} 
Constituição pelo Ato Adicional e a representatividade da eleição realizada, como argumento para defender uma nova emancipação - a do jovem imperador. Em desdobramento a tal argumento, uma série de seis artigos intitulados "O eleito da Nação", a partir da edição de 22 de fevereiro, denunciava o desrespeito aos princípios constitucionais que grassava na sociedade imperial - "não há país onde mais se fale de princípios, nem também onde mais se tenham adulterado e reduzido ao nada como no Brasil". De modo arguto, já havia chamado a atenção, em artigo a que deu o título de "Razão de Estado", no número inaugural, para o uso e lugar de determinadas palavras e expressões nas falas do regente. De acordo com Abreu e Lima, o uso de expressões como "providências de salvação pública", "necessidade das circunstâncias", "segurança pública" não deveriam passar desapercebidas, uma vez que “denotam certos atos de violência praticados por uma autoridade arbitrária".

Mas ele se empenharia, sobretudo, em denunciar a ilegitimidade do governo de Feijó:

Deixamos provado no número anterior, que o povo do Brasil não tinha concorrido de modo algum, nem direta ou indiretamente, para a eleição do Sr. Feijó, e, portanto, que o título indevido, que se lhe dá, de eleito da nação, é um escárnio da boa fé deste mesmo povo. (RAIO DE JÚPITER, 22 fev.1836)

$\mathrm{O}$ ataque ao governo e à administração do padre-regente - durante a qual agravou-se a luta da Cabanagem na província do Grão-Pará e teve início a Guerra dos Farrapos na província do Rio Grande de São Pedro, tornando urgente "cortar a raiz venenosa das revoluções que tantos renovos vai brotando no Brasil" - tinha como corolário a defesa da assunção da princesa Dona Januária como imperial-regente do Império, a "precursora dos destinos deste vasto império".

A cada linha do Raio de Júpiter ficava explícito o valor que Abreu e Lima emprestava à imprensa, assim como se evidenciava a questão dos limites que lhe deveriam ser impostos. 
A imprensa periódica é o cadinho por onde passa o critério público; é tal a potência deste reativo que destrói todas as preocupações, todos os erros populares, todas as imposturas e ultimamente mina e solapa o despotismo e a arbitrariedade, e vigora a liberdade e a moral pública. (RAIO DE JÚPITER, 11 fev.1836).

Para o redator do Raio de Júpiter, se a imprensa exercia uma ação benéfica, ela exigia do escritor público justiça e bom senso. Em nenhum momento, em sua opinião, poderiam ser permitidos excessos por parte da imprensa. A liberdade excessiva poderia colocar em risco certos princípios. No campo político, por exemplo, as idéias liberais extremadas e republicanas, assim como a "moralidade vigente" e a corrupção alimentavam a dissolução do país. Se os jornais que circulavam na cidade do Rio de Janeiro ajudavam a constituir uma opinião pública, havia que se tomar cuidado com a tal opinião pública, que satirizou em um artigo:

É uma prostituta já safada, que se vendeu caro na Europa e, depois de ter malbaratado toda a sua fortuna, veio para a América com enfeites falsos e europeus a enganar-nos com suas lisonjas e boas graças. (RAIO DE JÚPITER, 22 fev.1836).

Buscando ampliar, ainda desta vez, seu raio de influência, o redator estabeleceu contatos com os responsáveis por outros periódicos, em outros pontos do país, como o Sentinela Rio-Grandense ao tratar da revolução no sul; não deixou de fazer oposição, porém, aos jornais editados pelos chimangos.

A oposição ferrenha ao governo Feijó, assim como a defesa da regência de Da. Januária, provocou a ira dos seus inimigos políticos, também nesta oportunidade. A partir do mês de março, Abreu e Lima passou a denunciar os periódicos que criticavam a posição assumida pelo Raio e clamavam pelo fim da impunidade na imprensa. Em seu entender, "a atitude combativa do Raio" era legítima e respeitava os princípios relativos à liberdade de imprensa que defendia como escritor público. 
No momento em que o impressor do Raio de Júpiter foi preso e julgado e que a censura se fez presente suspendendo um número do jornal, assim como quando, posteriormente, os soldados do Corpo de Permanente de Niterói cercaram a tipografia, Abreu e Lima publicou artigos exigindo do governo que tivesse "obrado com justiça e com decência", pontuando o fato, de domínio público, de ser ele o responsável pelo periódico. Não deixou também sem resposta os chimangos que o acusavam de abusar da liberdade de imprensa, ao mesmo tempo em que, nas páginas do jornal, agradecia ao júri que não considerou criminosos os números do Raio acusados por seus inimigos políticos.

A última edição do Raio de Júpiter veio à luz, no dia 3 de maio de 1836, um dia de feriado nacional em que se comemorava a inauguração dos trabalhos da Assembléia Constituinte - "este dia, verdadeiramente nacional, é para o Brasil o dia de sua maior glória, porque prova que o exercício de sua soberania está confiado aos representantes do povo". Nele, porém, seu redator não manifestaria "o dom de prever o futuro", ou seja, a mudança de rumos da política imperial, a partir do ano seguinte. Ela seria anunciada estrepitosamente pela renúncia de Feijó e pelo discurso de Bernardo de Pereira de Vasconcelos na Câmara dos Deputados - "Fui liberal [...] Hoje sou regressista". Iniciava-se o Regresso conservador - ou o início da "luta da Reação", no dizer de J. J. da Rocha.

Mas, ao que parece, Abreu e Lima tomara gosto do ofício de escritor. E para espanto apenas daqueles que, além de não acreditarem que viviam inúmeras vidas, podiam constatar então que algumas delas eram vividas ao mesmo tempo, fez publicar, em 1837, duas memórias de sua autoria na Revista Médica Fluminense - a Memória sobre o guaco, publicada anteriormente em Bogotá, em 1826, e a Memória sobre a elefância, oferecida ao Ministério do Império e publicada inicialmente no Diário Oficial (ABREU E LIMA, 1837a, p. 353-378; 1837b, p. 46-73).

Mas é provável que a muitos de seus adversários e detratores não teria causado espanto - antes pelo contrário, gostariam de ter podido dizer, caso dele tivessem tomado conhecimento - o Memorial redigido de próprio punho em 2 de agosto de 1841 e endereçado 
posteriormente ao imperador. ${ }^{28}$ Nele, dizendo falar com "a franqueza e lealdade de um soldado velho", oferecia ao jovem de pouco mais de 15 anos que passara a dirigir pessoalmente os destinos do Império, “a minha espada, que não está virgem de combates”. Fazia-o para poder pôr fim à guerra civil que dilacerava o Rio Grande havia seis anos. Voluntarioso, assegurava que "dentro de um ano, dou e empenho a V. M. I. a minha palavra de honra, que a Demagogia terá expirado", após tantas, infrutíferas e custosas tentativas de pacificação do Governo Geral. Tendo resultado, no seu entender, da ação política perniciosa dos liberais moderados do Rio de Janeiro, nos primeiros anos da Regência, a luta fratricida no extremo-sul era alimentada pelos acordos entre os rebeldes e os Caudilhos Orientais. Sempre dramático, implorava ao novo imperador que não deixasse ruir a obra de seu pai.

O Brasil é um vulcão, e o trono de V. M. I. está sobre a cratera; dentro de um ou dois anos, a este passo, não teremos nem Monarquia nem união. Os erros dos seus ministros têm colocado V. M. I. na dura alternativa de vencer e castigar já e já a rebeldia, ou de renunciar o Trono para sempre: Escolha, meu Senhor!

Ainda uma vez, Abreu e Lima reservava ao Imperador o papel de árbitro entre as forças que se apresentavam, alertando-o para a necessidade de ter em consideração tanto uma herança quanto os interesses da Nação. Todavia, no momento em que os liberais pegaram em armas nas províncias de Minas Gerais e São Paulo - as revoltas liberais de 1842 -, com a intenção de juntar suas forças às dos farroupilhas do sul e dos liberais pernambucanos do Partido da Praia, coisa que não se efetivaria, Dom Pedro II parecia já ter arbitrado a questão posta por Abreu e Lima: entre a pena e a espada, escolhera que o General de Bolívar empunhasse a primeira.

\subsection{Do Bosquejo ao IHGB}

Da Tipografia Niterói do Rego e Companhia saía, sob alguma expectativa, um novo livro em 1835. Intitulava-se Bosquejo histórico, político e literário do Brasil. O "Autor e

\footnotetext{
${ }^{28}$ Memorial reservado para ser apresentado a S. M o Imperador pelo General Abreu e Lima. IHGB, manuscrito de 02 de agosto de 1841 .
} 
Editor deste Bosquejo" era José Inácio de Abreu e Lima; e ele era oferecido “Ao Muito Alto, Muito Poderoso Senhor D. Pedro 2, Imperador do Brasil”, “por um Brasileiro”.

Conforme vinha explicitado logo na folha de rosto da publicação, sob a forma de um subtítulo que cumpria o papel de restringir e melhor definir o objetivo da obra, Bosquejo histórico, político e literário do Brasil era uma "Análise crítica do projeto do Dr. França oferecido em seção de 16 de maio último à Câmara dos Deputados, reduzindo o sistema Monárquico Constitucional, que felizmente nos rege, a uma República Democrática, seguida de outra análise do projeto do Deputado Rafael de Carvalho, sobre a separação da Igreja Brasileira da Santa Sede Apostólica".

Bosquejo Político, Histórico e Literário do Brasil resultava da reunião dos artigos publicados no Mensageiro Niteroiense e de outros artigos inéditos, produzidos em função dos acontecimentos então vividos. Constituía, em suma, uma ferrenha crítica a dois projetos de lei, em especial ao projeto do deputado Ferreira França, em defesa intransigente do governo monárquico e da inviolabilidade da Constituição de 1824.

Tendo se decidido a reimprimir "o Corpo de delito, assim como os artigos da Constituição que nos hão de servir para formarmos o processo do insigne Criminoso", o autor de Bosquejo denunciava "ao Povo Brasileiro o maior atentado que, nas atuais circunstâncias, poderia cometer um seu Representante", ao mesmo tempo em que, por meio de uma dedicatória, ainda uma vez reservava à figura do Imperador, representante máximo da Nação brasileira, o papel de árbitro ou juiz no confronto de idéias e opiniões que distinguiam a constituição de um novo Estado, nos marcos do constitucionalismo.

Como se estivesse se apresentando perante um tribunal, aquele "súdito leal" assim procede porque

Não é o Imperador unicamente a quem o Deputado [Ferreira França] ofendeu no seu projeto, é a Nação inteira da qual o Sr. D. Pedro II é Sagrado Pupilo, e debaixo de cuja salva e guarda repousa durante a sua menoridade. A Nação deve vindicar a sua honra com a dignidade que corresponde a um 
Povo civilizado, pronunciando-se de uma maneira que não reste dúvida sobre a louca e temerária proposição do Deputado França. (ABREU E LIMA, 1835, p. 5).

O projeto de Ferreira França propunha que - "Do presente em diante todos os que nasceram no Brasil são livres. O patrimônio do Brasil cessará de ser patrimônio de uma só família. A Nação será governada por um chefe eleito de dois em dois anos, no dia 7 de setembro, à maioria dos votos dos Cidadãos eleitores do Brasil”. (ABREU E LIMA, 1835, p. 5). Em larga medida, ele repercutia muitas das idéias e proposições que circulavam pela Corte, de boca em boca, pelas páginas dos jornais, em alguns debates na Câmara dos Deputados, desde fins do Primeiro Reinado, incorporando "ideais democráticos aos princípios liberais clássicos", tais "como a soberania do povo, o sufrágio universal, a igualdade social e o governo republicano e toda a tradição do humanismo cívico”. (BASILE, 2004, p. 227).

De acordo com Barbosa Lima Sobrinho, o projeto de Ferreira França fora levado apenas à primeira discussão na Câmara, tendo sido o seu encaminhamento rejeitado por uma pequena diferença de votos, o que a Abreu e Lima, ainda assim, parecia preocupante. ${ }^{29}$ Para refutar a proposição de Ferreira França, temendo talvez que ela empolgasse a alguns daqueles que estavam na praça pública, o autor de Bosquejo realizou inicialmente uma análise crítica do projeto para, em seguida, expor sua argumentação. Esta tinha como eixo a apresentação das peculiaridades que distinguiam cada uma das nações americanas que experimentavam um governo republicano em contraste com a formação brasileira, de modo a recusar o que era entendido como as proposições genéricas e abstratas que distinguiam o pensamento liberal, e não raro desembocavam em projetos democráticos e republicanos. A América contrapunha-se à Europa, ele não duvidava; a América era a terra da Liberdade, que recusava o Despotismo; mas a América não era um todo homogêneo.

Seguros de nossa consciência, firmes no propósito de sotermos a toda custa a causa Monárquica no Império do Brasil estamos resolvidos a combater a

\footnotetext{
29 “A rejeição não somou senão 44 votos contra 33, uma diferença, pois, de 11 votos ou de seis votantes num total de 77 deputados" (BARBOSA LIMA SOBRINHO apud ABREU E LIMA, 1979, p. 15).
} 
todo sistema que se dirija a desvirtuar a essência da nossa lei fundamental. (ABREU E LIMA, 1835, p. 38).

A partir de uma afirmativa categórica - "os governos são criados para os Povos e não os Povos para certa classe de governo" (ABREU E LIMA, 1835, p. 38) ${ }^{30}$-, ele convidava o leitor a examinar, sob a sua orientação, "os elementos primitivos" dos Estados Unidos, exemplo de uma República democrática, assim como os do México e da Colômbia. Recuperava, então, o que chamava "as circunstâncias" destas sociedades enquanto colônias e na era da emancipação política. Nelas, tudo concorrera para fortalecer a homogeneidade, o que tornava viável a escolha da forma republicana de governo, o mesmo não tendo ocorrido no Brasil. Para argumentar recorria, então, a aspectos que podemos classificar como culturais - a educação, a composição da população, a existência de homens sábios, a qualidade da literatura, a elaboração de um conhecimento sobre a realidade de cada país -, operando, desta forma, um sensível deslocamento na discussão a respeito das opções que se apresentavam aos brasileiros, as quais não deveriam se restringir a elementos estritamente vinculados ao pensamento político. Um deslocamento que, certamente, não lhe era exclusivo, mas que ele se esforçava por colocar em plano destacado. Talvez valha a pena recuperar alguns dos passos de sua argumentação.

Assim, no decorrer das lutas pela emancipação, os norte-americanos superaram as diversidades internas e conquistaram a liberdade proclamando uma República confederativa.

Pela estrutura dos diferentes associados, vê-se que os Estados Unidos formando uma Confederação, fizeram tudo quanto podiam de boamente fazer para unirem-se, pois que antes não havia nexo algum que os ligasse; pelo contrário, as suas respectivas opiniões religiosas tinham muitas vezes provocado rivalidades e rixas que em algumas ocasiões foram funestas; porém tudo cedeu diante do perigo comum; tudo se sacrificou ao ídolo da Independência, e a liberdade foi indestrutível. Que povo maravilhoso! (ABREU E LIMA, 1835, p. 44).

\footnotetext{
${ }^{30}$ A afirmativa aparece nas primeiras linhas dos seguintes textos que compõem o Bosquejo: "As repúblicas americanas e o Brasil. Estados Unidos, México e Colômbia"; "O Brasil"; "Paralelo entre o nosso estado moral e o dos nossos vizinhos e conterrâneos"; e "Nosso estado intelectual, conclusão".
} 
A homogeneidade que caracterizava os Estados Unidos estava relacionada também à educação difundida entre os seus habitantes, a qual "correspondia à austeridade de seus princípios religiosos". Ainda que a ilustração tenha sido pouco difundida entre eles, surgiram "homens de grande saber" no decorrer das lutas pela independência, nomes respeitados que continuavam a ser conhecidos e seguidos até mesmo na Europa, - Franklin, Jefferson, Hamilton, Madison, Washington, entre outros. (ABREU E LIMA, 1835, p. 44).

Para sublinhar as características que distinguiam as colônias da América espanhola, Abreu e Lima punha em destaque as viagens realizadas por sábios europeus. Do seu ponto de vista, Humboldt, por exemplo, admirara o grau de ilustração existente em vários povos. $\mathrm{O}$ sábio alemão creditara às primeiras civilizações dos povos indígenas a sabedoria que constatara existir entre os mexicanos. O conhecimento de mineralogia e a existência de "monumentos colossais [...] dão ao México a idéia do Povo mais culto e mais antigo do nosso continente". (ABREU E LIMA, 1835, p. 45).

Desde cedo, o sistema colonial espanhol - "muito mais ilustrado que o português" instalara universidades nas colônias e tratara os americanos com igualdade de direitos ao nomear um número expressivo de homens para exercerem cargos importantes na administração colonial. Por sua vez, a literatura espanhola era vasta e "senão a mais rica, a mais antiga da Europa”. (ABREU E LIMA, 1835, p. 62).

O mesmo Humboldt ao percorrer o Reino de Nova Granada e a Capitania Geral da Venezuela havia declarado a sua admiração pela universidade de Nova Granada. Na Colômbia, além da universidade de Caracas, que já contava um século de existência, outras três universidades formavam jurisconsultos, naturalistas, matemáticos. Em suas viagens pela região o cientista havia contado com o apoio e a sabedoria de matemáticos e naturalistas formados por aquela instituição e que mais tarde formaram a República da Colômbia. Os estudos que foram realizados por tantos "homens sábios" tornavam possível, nos dias em que escrevia, obter dados confiáveis sobre as riquezas naturais e a geografia da região, assim como sobre a composição da sua população. 
Tudo fora diferente, do seu ponto de vista, na experiência do Brasil. A Coroa portuguesa não se interessara em abrir universidades, assim como não incentivara a vinda de expedições científicas à colônia americana. $\mathrm{O}$ monumento do saber português estava todo fundado nas Memórias da Academia Real das Ciências, que a seu ver constituia uma produção pobre. E concluía que

[...] somente o pobre e o desgraçado Brasil esteve vedado a todos os sábios e viajantes; somente os brasileiros estiveram privados do comércio do mundo civilizado; somente o nosso país não pode ser explorado, nem as nossas alturas medidas, nem observado nossos climas; nem tivemos nunca uma Universidade, nem um colégio à exceção de Seminários, onde toda a instrução se reduzia às noções mais simples dos rudimentos clássicos.

Eram tais diferenças que explicavam, a seu juízo, os caminhos diversos trilhados pelos países americanos e a inviabilidade da solução republicana para o Brasil. Não era possível dispor de dados confiáveis sobre a situação da população em qualquer época e o conhecimento disponível sobre o próprio território era quase nulo. Entre os habitantes do Brasil a ilustração não se desenvolvera, eram raros os homens sábios e a sua literatura era a portuguesa.

Coisa inteiramente distinta ocorria em relação às repúblicas americanas. Segundo o censo de 1783, a população dos Estados Unidos totalizava aproximadamente 2,7 milhões de habitantes, sendo a quarte parte composta por escravos. Em 1830, segundo cálculos do governo dos EUA, a população branca aumentara e a escrava diminuira, agora reduzida a um sexto. A população total do México alcançara um total de 6.800 .000 habitantes sendo que os escravos somavam 400.000. A Colômbia, embora ainda possuísse 300.000 escravos, isto é, um quarto de toda a sua população, "em um período de mais de três lustros [...] não terá um só escravo. Desta arte concebe-se perfeitamente como aquele Povo marcha para a liberdade política, sancionando a liberdade civil, que é a primeira e a mais grata de todas as liberdades" (ABREU E LIMA, 1835, p. 50). E oferecia ao seu leitor uma tabela de modo a melhor compreender as diferenças na composição populacional de cada país. 


\begin{tabular}{|lc|c|c|c|}
\hline \multicolumn{2}{|c|}{$\begin{array}{c}\text { População } \\
\text { Livre }\end{array}$} & $\begin{array}{c}\text { População } \\
\text { Escrava }\end{array}$ & $\begin{array}{c}\text { População } \\
\text { absoluta }\end{array}$ & $\begin{array}{c}\text { População } \\
\text { escrava respectiva }\end{array}$ \\
\hline Brasil & 2.250 .000 & 2.250 .000 & 4.500 .000 & $1 / 2$ \\
EUA & 1.979 .475 & 659.825 & 2.639 .300 & $1 / 4$ \\
Colômbia 2.400 .000 & 300.000 & 2.700 .000 & $1 / 9$ \\
México 6.400 .000 & 400.000 & 6.800 .000 & $1 / 17$ \\
\hline
\end{tabular}

Se era possível encontrar dados sobre as populações dos EUA, do México e da Colômbia, o mesmo não acontecia em relação ao Brasil. E mais do que isso: a população brasileira encontrava-se cindida ao meio, "metade de um povo agrícola, cujos produtos são todos devidos aos braços cativos". (ABREU E LIMA, 1835, p. 50).

Uma população dividida entre pessoas livres e pessoas escravas, sendo que a parte livre estava dividida em quatro famílias:

Esta situação é concebida de modo seguinte $=$ negros livres, mulatos livres, brancos natos e brancos adotivos = sem contarmos com os Índios (que ainda formam uma quinta família) por ser uma classe inerte, e de nenhum peso em política. Que país no mundo apresenta um quadro tão informe? Revestidos de vários matizes representamos um verdadeiro prisma, que exposto aos raios do sol mostra cores de um Íris espantoso, Íris de guerra, que em nada se parece com o Mensageiro de Juno. Que somos todos os inimigos e rivais uns dos outros na proporção de nossas respectivas classes. (ABREU E LIMA, 1835, p. 56).

Mas ele não deixava de acrescentar que

[...] a urbanidade exige que façamos uma advertência ... escrevemos para o povo, e por isso temos empregado uma frase clara, pura e sem rodeios; e estamos resolvidos a evitar paráfrases e metáforas, tão impróprias de um artigo de periódico; portanto quando empregarmos as denominações branco, mulato ou negro, deve entender-se como acidentes para denotar uma classe, pois que ninguém deverá persuadir-se que possamos usar de uma expressão 
com o desígnio de ofender a pessoa alguma, nem para menoscabar a dignidade de uma porção de homens, que em nosso conceito têm tanto direito à nossa benevolência, como outra qualquer classe ou indivíduo. (ABREU E LIMA, 1835, p. 56).

Não havendo liberdade civil para todos, "não podemos aspirar completamente à liberdade política" (ABREU E LIMA, 1835, p. 56). Ora, a escravidão caminhava para a rápida extinção em países como a Colômbia, mas o mesmo não poderia ocorrer no Império do Brasil. Ainda que o seu final imediato pudesse representar um ato de respeito à dignidade de uma classe, ela era inviável naquela oportunidade: "a liberdade civil seria a morte política do Brasil; seria o ataque mais pernicioso contra a propriedade; seria finalmente a destruição do Estado" (ABREU E LIMA, 1835, p. 54). E o autor de Bosquejo argumentava a respeito de tal consideração, dirigindo-se aos que dele discordavam: "porém nós perguntamos agora a todos os demagogos do Brasil: o que se pratica com a nona parte da população em Colômbia, poderia acaso verificar-se, quando se trata da metade de um Povo agrícola, cujos produtos são todos devidos a braços cativos?” (ABREU E LIMA, 1835, p. 50). Se os brasileiros desejassem respeitar o dogma da liberdade e sancionar os direitos naturais, políticos e civis deveriam saber que as reformas só podiam ser realizadas "com lentidão e com tino".

Eram todos esses fatores, aliados a outros mais, que diferenciavam o Brasil. Eles haviam se manifestado à época da emancipação política de um modo muito particular:

\footnotetext{
“[...] nos julgamos desligados do resto do mundo e muito superiores àqueles que nos tinham legado todos os seus vícios sem nenhuma de suas virtudes".
}

Não obstante, importava não esquecer que "para salvar-nos do naufrágio que nos aguarda é forçoso reconhecer o que somos: [...] somos portugueses, porém já degenerados".

Nestas circunstâncias, no seu entender, a solução monárquico-constitucional para o Brasil tornava-se irrecusável. "A forma do governo é a que distingue o predicado do Pacto Social; isto é, se o chefe da sociedade é vitalício e hereditário a Constituição que o estabelece 
é monárquica”. E tal tornava a pessoa do Monarca inviolável e sagrada. Como detentor do Poder Real e exercendo o Poder Moderador, o Monarca propiciava a harmonia entre os poderes políticos, e aí residia a garantia e a salvaguarda da Liberdade. De tudo isto resultava que atentar contra o Imperador, como o fazia o projeto de Ferreira França, era atentar contra o primeiro representante da Nação, contra a harmonia dos poderes políticos,

“[...] é atentar contra a Nação”. (ABREU E LIMA, 1835, p. 18).

Para o autor de Bosquejo, pois,

[...] a política não é, propriamente falando, senão a moral aplicada entre o homem, como simples cidadão e o corpo social. Se a moral não forma a base da nossa legislação, podemos assegurar que há interesses em perpetuar a ignorância do Povo, dando-lhe uma falsa idéia dos seus deveres e direitos. Atendei que a melhor garantia do sistema representativo é a opinião pública. (ABREU E LIMA, 1835, p. 22).

Era para ela que se voltaria cada vez mais, sempre com uma preocupação pedagógica, embora se servindo de outros discursos e suportes.

Tendo sido aceito, em 1839, como sócio honorário do Instituto Histórico e Geográfico do Brasil, fundado no ano anterior, cuidou de oferecer à Instituição, por meio de uma carta, um exemplar de Bosquejo histórico, político e literário do Brasil, ao mesmo tempo em que fez a doação de um documento. A "moderna história" do Brasil começava a fasciná-lo agora, como texto.

[...] Igualmente tenho a honra de oferecer ao Instituto um manuscrito [...] cujo valor é inestimável; pelo que muito me gostaria vê-lo quanto antes publicado, para que se não perdesse a relação de um acontecimento tão extraordinário, e tão notável em a nossa moderna história. $\mathrm{O}$ documento, de que falo, é parte original de todas as circunstâncias que deram lugar à 
infausta revolução da província de Pernambuco em o dia 6 de março de 1817, endereçada ao então secretário d'estado, conde de Barca, pelo capitãogeneral da mesma província Caetano Pinto de Miranda Montenegro (depois Marques da Praia Grande), no momento de chegar a esta corte, e de ser recolhido preso à fortaleza da Ilha de Cobras. Este singular documento foi extraído do gabinete del rei na ocasião de sua partida para Portugal, e conservado por um Brasileiro de ilustração, que tinha entrada naquele gabinete; e ainda que se ache roto na parte que continha a assinatura do dito capitão-general, a relação é tão exata, e os fatos tão bem esmiuçados, que não é possível poder-se duvidar da sua autenticidade. E ainda quando pudesse haver dúvida a esse respeito, existe felizmente o visconde da Praia Grande, filho daquele marquês, que pode reconhecer e atestar a identidade deste documento, que tanta honra faz a seu finado pai pela decência, moderação e verdade com que narrou fatos, que lhe eram tão dolorosos, e que deviam feri-lo no íntimo de seu coração. Em todo caso, pela maneira por que tive a fortuna de haver esse papel, posso afirmar com toda a convicção de minha alma, que ele é autêntico, o mesmo que original fora feito e assinado pelo ex-governador de Pernambuco.

A doação foi submetida, como de praxe, à Comissão de História. Por meio de um parecer, declaravam seus membros que

[...] tendo examinado o documento oferecido ao Instituto Histórico e Geográfico Brasileiro pelo Sr. General José Inácio de Abreu e Lima, e que consiste na original participação oficial do governador de Pernambuco, Caetano Pinto de Miranda Montenegro, sobre a revolução daquela província no ano de 1817 , entende que, conquanto, não convém todavia publicá-lo já pelo comprometimento que a sua publicação poderia levar a pessoas ainda existentes; e por isso a comissão é de parecer que o sobredito documento seja guardado nos arquivos do Instituto até que todos os nomes nesse documento mencionados tenham comprometido perante o tribunal da posteridade. (REVISTA DO IHGB, t. I, seção 29, p. 378 e 379). 
A decisão do Instituto não foi suficiente, ela também, para esmorecer o escritor Abreu e Lima. No ano seguinte, ele ainda podia ser encontrado na imprensa periódica e militante, como em O Maiorista. Mas algo mudava, em ritmo cada vez mais acelerado.

Tangidas certamente pelos ventos do Regresso conservador, as opiniões e os debates refluíam da Rua e da praça pública para o Estado; e o espaço da Casa se abria para os folhetins, que começavam a dominar nos rodapés da imprensa periódica (ALENCAR, 1965, p. 101-128; MEYER, 1996). Justiniano José da Rocha diria que aquele era o tempo do "triunfo da Reação", que logo seria sucedido pelos anos da "Transação" monárquica. Eram também os anos de uma avassaladora expansão para dentro levada a cabo pelos dirigentes imperiais, particularmente pelos saquaremas.

E Abreu e Lima, ao que parece, a percebeu. Afinal, para cerzir uma deliberação consciente já algo rota, servia-se dos fios que lhe emprestavam os construtores do Estado imperial. Revela-o os dois volumes do Compêndio da História do Brasil apresentados ao Instituto Histórico e Geográfico do Brasil, em 1843. 


\section{UM COMPÊNDIO DA HISTÓRIA DO BRASIL}

compêndio, s. m. Epítome, resumo do mais substancial, ou das noções elementares de alguma arte, sciencia, ou preceitos: v.g. compendio da doutrina; de lógica; de Direito Natural. Em compendio: resumidamente.

Antonio de Moraes e Silva. Diccionario da Língua Portugueza, 2a . edição, 1813.

compêndio, s. m. (sXV cf.IVPM supl.) 1 resumo de uma teoria, ciência, doutrina etc. 2 p.met. livro, esp. escolar, que enfeixa tal resumo $<u m c$. de geografia $>3$ p.metf. pessoa ou coisa que resume ou simboliza em si um período histórico uma teoria ou doutrina, uma ou diversas qualidades etc. < Da Vinci foi um c. do Renascimento $>*$ em c. de modo condensado, conciso * ETIM lat. compendium, ii, inicialmente 'peso de prata', daí 'ganho, produto da economia, parcimônia, pouco gasto, lucro', especialmente 'economia de tempo, abreviado', donde 'compêndio, suma, resumo'; ver pend-; f.hist. 1519 cõpêdio SIN/VAR ver sinonímia de resumo * PAR compendio (fl. compendiar)

Antonio Houaiss e Mauro de Salles Villar. (Dicionário Houaiss da Língua Portuguesa, 2001).

Quase dois séculos separam a edição tornada clássica de Moraes e Silva e a obra monumental de Houaiss; entre ambas, um mínimo de diferenças, quase nenhuma, entre os significados registrados para compêndio. Da consulta aos dois antonios parece destacar-se a advertência, quase um conselho, de que talvez seja melhor guardar uma "economia de tempo" na busca de diferenças entre um provável modo antigo de utilização da palavra e outro atual.

No que mais de perto me interessa, e dizendo "de modo condensado, conciso", se em derivação por metonímia compêndio constitui, ontem como hoje, um "resumo do mais 
substancial", um "livro que enfeixa um resumo", especialmente um "livro escolar", talvez não seja ocioso sublinhar que para nós, hoje, um compêndio é algo bastante diferente do que entendemos por um livro didático. Há muito sabemos, professores e autores de livros didáticos, que estes não são atualmente o "resumo de uma teoria, ciência ou doutrina", do que elas possuem de "mais substancial" ou de suas "noções elementares"; e que, no caso específico dos livros didáticos de História, eles não são simplesmente a "suma" ou o "resumo" da produção historiográfica.

"Resumidamente": foi nos anos imediatamente seguintes à Maioridade de Dom Pedro II que Abreu e Lima, seguindo sugestão alheia, tomou a decisão de prestar-se "ao encargo de formar" um compêndio "para uso da mocidade Brasileira" (ABREU E LIMA, 1843, p. 8). E o formou: em 1843 surgia o Compêndio da História do Brasil. 


\title{
1. ABRINDO O COMPÊNDIO
}

Tenho em minhas mãos o Compêndio, editado em dois tomos na primeira edição de 1843.

Abro o primeiro deles.

Na folha de rosto, na parte superior, aparece o nome da obra

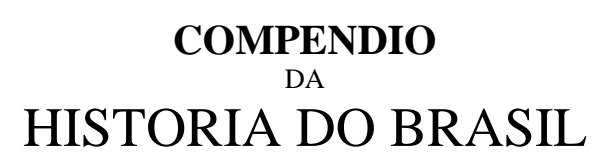

Logo abaixo, duas apresentações: a do autor -

PELO GENERAL

\section{J. I. DE ABREU E LIMA}

NATURAL DA PROVÍNCIA DE PERNAMBUCO

Membro honorário do Instituto Histórico e Geográfico Brasileiro. Autor do Bosquejo

histórico, político e literário do Brasil

e das Memórias sobre o Guaco e sobre a Elefância

- e a dos editores -

\author{
RIO DE JANEIRO \\ Publicado e à venda em casa dos Editores \\ EDUARDO \& HENRIQUE LAEMMERT \\ Rua da Quitanda, 77 \\ 1843
}

Entre as duas apresentações, como se tivesse a função de separá-las, o brasão imperial. Mas esta primeira impressão logo se desfaz, porque o brasão ali está como o símbolo do elemento que propiciou uma relação necessária para a concretização de um projeto deliberado 
de ambos: o Estado imperial. Relação entre sujeitos assimétricos, o que se evidencia no destaque dado ao nome do autor em negrito.

Na página oposta, como frontispício, uma "estampa" do primeiro imperador do Brasil, Dom Pedro I. Consultando o tomo segundo, constato que o retrato do pai cedeu lugar ao do filho, Dom Pedro II, um jovem em torno dos 18 anos.

Ambas as estampas tornavam tangíveis o elemento propiciador de uma relação essencial. Também desta vez o Estado imperial se apresentava por meio da figura do Imperador. As estampas parecem insinuar que o Compêndio a ambos era dedicado.

Mas não era exatamente assim. Logo após, na quarta página, encontro em primeiro lugar o anúncio ou o início de uma dedicatória:

\title{
DEDICATÓRIA
}

Com especial permissão

De S. M. I.

E, a seguir

\author{
Ao \\ Muito alto, muito poderoso \\ SENHOR D. PEDRO II \\ Imperador Constitucional e Defensor Perpétuo \\ do Brasil \\ ODC \\ Este compêndio de História Pátria \\ Em sinal de profundo respeito e da mais \\ Pura afeição e lealdade
}

Seu reverendo súdito

José Inácio de Abreu e Lima 
Ao homenageado não incomodaria, por certo, a apresentação do autor como "natural da província de Pernambuco". Ali, aquela identificação significava menos - ou nada - a recordação de experiências pretéritas do autor, as quais tinham oposto a província ao centro político do Império, e revelava muito mais a plena incorporação do "natural" daquela província a um sentimento novo, abrangente e envolvente - o sentimento nacional. Tendo surgido por volta de 1835, de acordo com a informação contida em Houaiss (HOUAISS, 2001), a nova expressão dava conta de algo que cada vez mais era compartilhado pelos brasileiros, incorporando, quebrando ou superando sentimentos locais ou provinciais em proveito de uma convivência comum. A esse respeito, talvez seja interessante lembrar que Francisco Adolfo de Varnhagen, cuja trajetória como historiador em determinado momento cruzou de modo íntimo e intenso com a trajetória de Abreu e Lima em decorrência da publicação do Compêndio, conforme será visto em detalhes mais adiante, ao publicar sua História Geral do Brasil, em 1854, também a dedicando ao imperador D. Pedro II, por preferir o anonimato apresentou-a como tendo sido redigida "por um sorocabano".

\section{Chego ao "Prefácio".}

Nele estão expostas as intenções de Abreu e Lima ao "formar" aquele que, no seu próprio dizer, vinha "a ser o primeiro Compêndio da História do Brasil". ${ }^{31}$ A primeira delas consistia em fazer algo que pudesse ser usado pela "mocidade Brasileira", conforme já destaquei acima; a segunda, em contribuir para a formação de "uma literatura propriamente brasileira" (ABREU E LIMA, 1843a, p. vii).

É à segunda delas que o autor parece dar maior atenção. Assim, para o pernambucano Abreu e Lima,

[...] um país, que apenas conta vinte anos de existência como nação, não pode ter literatura propriamente sua; porque nos primeiros desenvolvimentos da inteligência não é dado tocar a perfeição, que se requer nas obras do espírito humano. Todas as nações existiram anos e séculos antes de

\footnotetext{
${ }^{31}$ Esta e as citações seguintes são retiradas do "Prefácio"; os números entre parênteses indicam a localização nas páginas.
} 
possuírem uma literatura própria; e só depois da introdução das artes e das ciências, é que cada povo as vai apropriando e desenvolvendo segundo o caráter nacional, e formando deste modo o pecúlio de suas doutrinas e fatos. Assim foi que as artes precederam as ciências, que a crônica precedeu a história, porque começou-se pela prática e acabou-se pela teoria (ABREU E LIMA, 1843a, p. v-vi).

A intenção era expressa com clareza, o que não impedia que fosse polêmica, porque se muitos componentes da boa sociedade imperial concordavam com a opinião expressa pelo autor pernambucano a respeito da inexistência de uma "literatura própria", outros sustentavam que uma literatura brasileira existia anteriormente à emancipação política do Império do Brasil.

Seja lá como for, o que movia Abreu e Lima era o propósito de "lançar uma pedra no cimento do edifício", e assim contribuir com "a sua quota para o depósito comum" que permitiria a constituição de uma literatura nacional; guiava-o a certeza de prestar "importante serviço à sua pátria" (ABREU E LIMA, 1843a, p. vii).

Nesta oportunidade, porém, sua contribuição dar-se-ia em um ramo específico: o da história pátria. "Como na literatura propriamente dita tem o primeiro lugar a história", no entender do General de Bolívar, "nenhum serviço será mais apreciado do que aquele que começar por preparar-lhe os elementos" (ABREU E LIMA, 1843a, p. vii). Assim, se se pretendia escrever a história pátria tornava-se necessário, em primeiro lugar, averiguar e ordenar os fatos; corrigir e verificar as datas; e, sobretudo, consultar antigos documentos para salvá-los do esquecimento ou para comprovar muitos feitos. E ele se dispusera a empreender aquela tarefa inicial pelo único modo possível naquele momento, no seu entender: um compêndio.

Para formar o Compêndio, o autor diz que "servi-me em grande parte do trabalho alheio", "segui recopilações", "extratei” e "copiei” - compendiou, enfim. E não deixa de enumerar "as obras de que me servi" (ABREU E LIMA, 1843a, p. viii), discriminando-as ao 
se referir a cada capítulo "ou época". O ato de compendiar leva-o a sublinhar, em franqueza quase dispensável, que o trabalho "muito pouco tem de própria lavra", "não é uma composição inteiramente original”. De modo categórico afirma que a variedade de estilo nele presente não é um defeito ou filha da arte, e sim a conservação proposital do estilo dos autores copiados ou extratados.

Ele parece não duvidar que "o mérito de minha obra" consiste na

recopilação de grande número de fatos que se acham espalhados por muitos escritos em diferentes épocas, vindo a ser o primeiro Compêndio da História do Brasil, senão tão exato quanto podia sê-lo, ao menos o mais rico em documentos preciosos, alguns dos quais já são muito raros, e outros que apenas se encontram nas grandes coleções, difíceis de possuir pelo seu preço, e por isso quase impossível de consultar (ABREU E LIMA, 1843a, p. $\mathrm{x})$.

Mas ele parece também não ter dúvidas a respeito do mérito do Compêndio - razão de sua originalidade - residir justamente no procedimento que possibilitava a reunião do maior número de fatos possíveis: a organização daqueles fatos "em série por meio de uma muito exata dedução cronológica" (ABREU E LIMA, 1843a, p. viii). Uma organização que se expressava em uma divisão por "épocas" ou "capítulos" - oito no total, do Descobrimento à coroação de D. Pedro II -, cada uma delas assinalada por uma determinada "cor". Conforme sublinhava na carta em que enviara ao Secretário Perpétuo do IHGB, o cônego Januário da Cunha Barbosa, apresentando sua obra, na divisão das épocas "buscara sempre uma cor que as distinguisse, mas essa cor devia ser tal que se apresentasse à primeira vista e que, para ser bem compreendida, era mister que cada época tivesse seu cunho particular, isto é, uma mudança, uma variação do estado anterior". 32

Por tratar não apenas das gerações passadas, mas também da "época atual”, o autor diz ter se contentado especialmente em relação a esta "com assinalar os fatos sem nenhuma

\footnotetext{
32 "Carta de Abreu e Lima a Januário da Cunha Barbosa”, s.d., lida na sessão de 14 de setembro de 1843, Revista do Instituto Histórico e Geográfico do Brasil. 2. ed., 1843, t. 5, 370. (Cf. RODRIGUES, 1957, p. 155).
} 
reflexão. [...] Por este motivo antes quis passar por simples cronista do que por historiador, reservando minhas opiniões para não parecer temerário" (ABREU E LIMA, 1843a, p. xi).

Assim, por meio do "Prefácio", Abreu e Lima procurava sublinhar como o método e o estilo narrativo distinguiam o Compêndio que formara.

Mas isto certamente não é tudo! Se um prefácio é uma apresentação que convida à leitura, ele é também, em não raras oportunidades, o ponto de partida de indagações, que logo se transformam em questões, quer para os contemporâneos, quer para nós próprios, hoje. A exposição de uma de suas intenções por Abreu e Lima suscitaria, ontem como hoje, discussões a respeito da produção historiográfica e do lugar de seu texto no momento de surgimento de uma historiografia brasileira. Neste momento, porém, um outro tipo de questão me interessa em particular, a partir do próprio texto do "Prefácio", aguçando-me a curiosidade, por razões que já não preciso expor.

Afinal, não deixa de ser intrigante o fato de a primeira das intenções do autor para a elaboração do Compêndio ser apresentada por meio de uma simples frase - "formar - Um Compêndio da História do Brasil - para uso da mocidade Brasileira" - , em flagrante contraste com a alentada exposição a respeito da segunda delas, a qual se desdobra na exposição do modo como a concretizou.

Procuro compreender as razões de uma assimetria, se é que tais razões existiram, uma vez que a referência "para uso da mocidde Brasileira" ou equivalente não era incomum à época. ${ }^{33}$ Para tanto ponho em destaque duas circunstâncias que, em um intervalo de tempo de três ou quatro anos, em muitos momentos se cruzaram.

A primeira delas vincula-se ao IHGB, fundado em 1838; a segunda, aos editores.

\footnotetext{
${ }^{33}$ Como um único exemplo, entre inúmeros outros, cf. o "Resumo das instituições políticas do barão de Bielgeld, parafraseadas e acomodadas à forma atual de governo no Império do Brasil, oferecido à mocidade brasiliense por um seu compatriota pernambucano", referido por Sérgio Buarque de Holanda na "Apresentação" a J. J. da Cunha de Azeredo Coutinho, Obras econômicas: 1789-1804. São Paulo: Cia. Editora Nacional, 1966. Utilizo-o como exemplo pela significativa referência a uma "mocidade brasiliense" feita por um "compatriota pernambucano"...
} 
Aquele que, orgulhoso, recordaria pela vida afora ser o autor do "primeiro Compêndio da História do Brasil", orgulhava-se também de pertencer ao "Instituto", naqueles que viriam a ser os anos finais da experiência regencial. Então, se não sabia, ao menos talvez sentisse ser aquele o "lugar" - embora não exclusivo - onde começavam a ser forjados muitos dos elementos simbólicos que possibilitariam a consolidação da ordem monárquica, sob uma direção determinada. Ali, pois, deveria estar, para além das razões relacionadas aos atributos de honra e prestígio que a instituição colocada sob a proteção imperial passava a conferir. Sócio do IHGB desde o ano seguinte ao de sua fundação, Abreu e Lima procurava participar, ou ao menos acompanhar, as discussões e reflexões então predominantes entre os seus membros, referidas em larga medida ao "fim e objeto" da instituição, conforme expresso no Estatuto de sua fundação: “coligir, metodizar, publicar ou arquivar os documentos necessários para a história e geografia do Império do Brasil; e assim também promover o conhecimento destes dois ramos filológicos por meio do ensino público". ${ }^{34}$ Discussões e reflexões que, de modo quase inevitável, desdobravam-se nas questões referentes tanto aos "períodos" quanto ao modo "como se deve escrever a História do Brasil". A primeira delas - proposta pelo cônego Januário logo na primeira sessão da agremiação, em $1^{\circ}$ de dezembro de 1838 , sob a forma de um "programa" para "Determinar as verdadeiras épocas da história do Brasil, e se essa se divide em antiga e moderna, ou quais devem ser suas divisões" - tendeu a seguir as indicações do Brigadeiro Cunha Matos, o qual propunha uma periodização em "três épocas" - a primeira relativa aos aborígenes; a segunda tratando das eras dos descobrimentos pelos portugueses e da administração colonial; e a terceira abrangendo os acontecimentos desde a emancipação política. ${ }^{35}$ A segunda, isto é, aquela que dizia respeito a "como se deve escrever a história do Brasil", desaguaria na proposição, também pelo Secretário Perpétuo, por ocasião da $51^{\mathrm{a}}$ sessão da instituição, em novembro de 1840 , de um concurso público que oferecia um prêmio de $\mathrm{R} \$ 200 \$ 000$ a quem elaborasse um plano coerente a respeito. Como é sabido, na avaliação dos sócios efetivos do IHGB, a questão foi respondida de modo satisfatório pelo bávaro Karl Friedrich Philip Von

\footnotetext{
${ }^{34}$ Revista do IHGB, tomo I, 1839 (Extrato dos Estatutos). Conforme destaca com pertinência Michel de Certeau, "Em história, tudo começa com o gesto de separar, de reunir, de transformar em "documentos" certos objetos distribuídos de outra maneira. Esta nova distribuição cultural é o primeiro trabalho. Na realidade, ela consiste em produzir tais documentos". (CERTEAU, 1982, p. 81) (grifos do autor). Sobre a fundação do Instituto e seus propósitos, (cf. GUIMARÃES, 1998).

35 "Dissertações acerca do sistema de escrever a história antiga e moderna do Brasil". RIHGB, 1863, t. XXVI. (Cf. também RODRIGUES, 1957, p. 152-181).
} 
Martius, que se apresentava como "um autor filosófico, penetrado das doutrinas da verdadeira humanidade, e de um cristianismo esclarecido" (MATTOS, 2000b). Tendo por título a questão que motivara o concurso, a Memória de von Martius era datada de 10 de janeiro de 1843 - o mesmo ano da edição do Compêndio.

Todavia, entre as duas proposições de Januário da Cunha Barbosa - a referente à periodização e a que resultou na Memória de von Martius - um acontecimento talvez ajude a compreender a decisão de Abreu de "formar" um compêndio e, mais do que isso, a tímida menção a respeito de sua primeira intenção no "Prefácio", abrindo caminho, assim, para a segunda trajetória. Um acontecimento que nem sempre tem merecido a atenção dos estudiosos, de modo até certo ponto também intrigante. Foi na sessão de 8 de fevereiro de 1840 que Justiniano José da Rocha - que ainda não redigira o panfleto "Ação, Reação, Transação", que o tornaria conhecido - deu ciência aos membros do Instituto que fora nomeado pelo governo para lecionar um "curso de História Pátria" no Imperial Colégio de Pedro II, criado no mesmo ano da fundação do IHGB. "Achava-se embaraçado" por não existir ainda um "bom compêndio da História do Brasil por onde se pudesse orientar [...] a fim de preparar as suas lições", razão por que propunha a nomeação de uma comissão especial para "organizar um Compêndio". Discutida a proposta, o cônego Januário não lhe foi favorável, "visto não estarem ainda bem elucidados alguns pontos de nossa História", acrescentando ainda existir o "bom compêndio do Sr. Bellegarde" (cf. Anexo II). Ainda assim, uma Comissão foi formada com aquela finalidade, mas dela nada resultou. Na sessão de novembro daquele mesmo ano, vimos acima, o Secretário Perpétuo conseguiria que fosse aprovado um concurso para premiar o melhor plano para a redação de uma História do Brasil..., a qual não deveria ser confundida com um compêndio.

Muito provavelmente também naquela oportunidade a proposta de Justiniano ecoava as preocupações de Bernardo Pereira de Vasconcelos, o formulador do Regresso Conservador. Verdadeiro criador do Colégio Pedro II, preocupava-o a inexistência de compêndios para uso dos alunos do Imperial Colégio de D. Pedro II, inclusive de história pátria, quer fossem redigidos por autores brasileiros, quer fossem a tradução de compêndios estrangeiros. Às preocupações de Vasconcelos somavam-se os esforços dos dirigentes saquaremas no 
"laboratório" da província fluminense com objetivo idêntico, pela mesma época (MATTOS, 2000b, p. 79-80; MATTOS, 2003, p. 238-265).

O pernambucano Abreu e Lima muito provavelmente de tudo isso tinha conhecimento, e a tudo isso não se mostraria indiferente - mas, como sempre, reagiria a seu modo! À sugestão de um plano, contraporia um livro; às intenções do cônego Januário contrapunha as suas, materializadas no Compêndio da História do Brasil. E por saber ou sentir ser importante estar no IHGB, cuidou de apresentar sua obra aos seus membros, por meio de uma carta lida na sessão de 14 de setembro de $1843,{ }^{36}$ suscitando respostas e reações diversas das quais cuidarei adiante.

Contudo, talvez valha a pena lembrar que, embora se afastando das intenções de Januário, Abreu e Lima se aproximava da proposta de Justiniano José da Rocha. Composto de um texto principal, complementado por notas e uma documentação copiosa, esta referida particularmente ao segundo tomo, o "Texto" de Compêndio parecia querer atender mais aos interesses do professor Justiniano ("um bom compêndio da História do Brasil por onde se pudesse orientar [...] a fim de preparar as suas lições”) do que às preocupações do ministro Vasconcelos; parecia dirigir-se mais ao professor do que aos alunos. Todavia, no Prefácio, ele não deixa de afirmar ser o possível uso pela "mocidade Brasileira" que o teria mobilizado a “formar" sua obra. Uma intenção que parece ter sido definida não apenas por decisão própria, mas, sobretudo, por sugestão e incentivo de outrem: em suas próprias palavras, “devo antes declarar, que a obra, que dou à luz, não é lembrança minha” (ABREU E LIMA, 1843a, p. viii). Sugiro, neste ponto, que a lembrança para a formação de um compêndio teria sido feita pelo editor - ou "editores", isto é, Eduardo e Henrique Laemmert -, o qual, certamente, não tinha seus olhos voltados para o IHGB, como estavam os de Abreu e Lima.

Parecendo oscilar, ao menos à primeira vista, entre professores e a mocidade brasileira, mas afinal decidindo-se por esta última, muito provavelmente a partir de uma "lembrança" do editor, a intenção do autor põe em destaque a segunda circunstância. Ela se refere às relações entre o autor e o editor, já representadas de modo sintético e expressivo na folha de rosto da publicação. Se elas retornam, agora, dando destaque a uma outra intenção -

\footnotetext{
${ }^{36}$ Ver a nota 32.
} 
a do editor - é porque ela possibilita pôr em evidência um terceiro personagem - o leitor. Para tanto, avanço um pouco no tempo.

Quando, quase duas décadas depois após a edição de Compêndio, Joaquim Manuel de Macedo redigiu as suas Lições de História do Brasil para uso dos alunos do Imperial Colégio de Pedro II, no próprio título da obra tornava explícito a quem dirigia o seu texto, pondo em destaque o caráter de manual escolar de sua obra. As duas décadas que separam as obras de Macedo e Abreu e Lima recomendam alguma cautela em qualquer exercício de comparação entre ambas; todavia, não apagam as diferenças entre os leitores que os dois autores tinham em vista: "alunos", no caso de Macedo; "a mocidade Brasileira", para Abreu e Lima. Assim, em Macedo, a identificação dos "alunos" como leitores pressupõe uma relação pedagógica e uma instituição específica, além de um programa da disciplina fixado pelo estabelecimento padrão do Império (cf. Anexo III), algo que parece distante das preocupações de Abreu e Lima, que parece muito mais operar com a representação de uma "idade da vida" - uma mocidade que, se já não era o "menino-diabo" caracterizado por Gilberto Freyre (1968, p. 68-70), ainda não se tornara plenamente adulta, mas logo deveria se tornar. Mas uma mocidade que, em não raras ocasiões, apresentava-se como a metáfora da Nação brasileira, também em sua mocidade: “[...] um país que apenas conta vinte anos de existência como nação". Ora, neste caso, o valor simbólico que, então, os componentes da boa sociedade imperial passaram a atribuir a um livro de História pátria fazia com que o conjunto constituído por uma determinada "idade da vida" fosse ultrapassado em muito por um outro, manifestando-se no caso de Compêndio, conforme será visto adiante, na lista de subscritores da primeira edição. Ademais, falavam de lugares diversos: como professor do Colégio de Pedro II, o autor de A Moreninha se dirige a um leitor-aluno; querendo estar no IHGB, Abreu e Lima se dirige a um leitor-moço. Expressavam, assim, intenções diferentes, as quais acabariam por determinar os lugares marcadamente diferentes nos quais os mesmos se situariam: ao privilegiar um dos elementos de uma relação específica no estabelecimento escolar, as Lições de Macedo inevitavelmente se situavam na interseção dos espaços do Estado e da Casa, pondo em destaque as sempre tensas relações entre instruir e educar; quanto 
a Compêndio, ao reafirmar para a "mocidade Brasileira" o projeto emancipacionista de seu autor, situava-se na interseção dos espaços do Estado e da Rua. ${ }^{37}$

Dispenso-me de acompanhar as vicissitudes de Lições; ${ }^{38}$ sigo com o Compêndio e as recepções diferenciadas que suscitou. Entusiasmo em alguns; indiferença em outros; insatisfação e desaprovação em terceiros. Recepções que definiriam, em larga medida, a trajetória do livro e as relações de Abreu e Lima nos anos seguintes. Abreu e Lima reagia propiciando aproximações e afastamentos: dos editores, dos sócios do IHGB, de políticos e do próprio Imperador; na leitura de cada um daqueles brasileiros cruzavam-se as duas circunstâncias que haviam conduzido à eleição de um leitor original, gerando convergências e polêmicas, como a que opôs Abreu e Lima a Francisco Adolfo de Varnhagen no IHGB. Para muitos leitores, Compêndio poderia reavivar - perigosamente ou não - sentimentos e práticas que haviam distinguido os tempos finais do Primeiro Reinado e iniciais das Regências, tempos assim caracterizados por um memorialista:

Nasci e me criei no tempo da regência; e nesse tempo o Brasil vivia, por assim dizer, muito mais na praça pública do que mesmo no lar doméstico; ou, em outros termos, vivia em uma atmosfera essencialmente política que o menino, que em casa muito depressa aprendia a falar liberdade e pátria, quando ia para a escola, apenas sabia soletrar a doutrina cristã, começava logo a ler e aprender a constituição política do império (RESENDE, 1944, p. 67).

Com perspectiva diversa, ao discursar na sessão comemorativa do primeiro aniversário do IHGB, o sempre presente Januário da Cunha Barbosa, ao mesmo tempo em que sublinhava orgulhosamente o valor da instituição, também parecia antecipar para o futuro autor de Compêndio alguns dos argumentos que, algum tempo depois, sustentariam a crítica violenta que dirigiria à obra. E, ao fazê-lo, caracterizando os novos tempos que se abriam com o Regresso Conservador, Januário revelava "uma mudança, uma variação do estado anterior", como propunha o próprio Abreu e Lima para a identificação da "cor" que define uma época,

\footnotetext{
${ }^{37}$ A respeito dos espaços do Estado, da Casa e da Rua, cf. Mattos (2003, p. 103-121).

${ }^{38}$ Para tanto, remeto o leitor a Mattos (2000b).
} 
ainda que, de modo irônico, talvez ele não o tivesse percebido. A citação é longa, mas vale por sua contundência:

[...] a opinião de certas pessoas que julgavam incapaz de medrar na Terra de Santa Cruz um estabelecimento literário de tal natureza, sem atenderem que o espírito brasileiro se tem distinguido sempre pela literatura, e que a política não pode ser por muitos tempos o estudo dominante da nossa talentosa juventude. A exaltação das idéias que ela sofrera pelos acontecimentos da nossa independência, da nossa liberdade e da nossa fundação constitucional representativa parece que já toca o ensejo em que esfriam as fogosas paixões políticas, restabelecendo-se essa natural tranqüilidade de espírito e que se concebem idéias luminosas que adiantam a marcha das ciências e das artes, inimigas sempre de comoções revolucionárias. As letras têm felicitado as nações em que floresceram; porque os costumes públicos então se melhoram é porque a experiência do passado, recomendada nas páginas da história, oferece suficientes esclarecimentos ao presente e ao futuro. Se os homens de Estado, que têm a seu cargo a direção dos negócios da pátria, não se pode dispensar dos conhecimentos históricos e geográficos do seu país, também aqueles que em administrações subalternas se esforçam para cumprir os deveres inerentes a seus cargos, devem ser ilustrados por esses conhecimentos. A história e a geografia do país necessitam em nossa pátria serem explicadas por um modo que aproveitassem a todos os Brasileiros. $\mathrm{O}$ Instituto tomou a seu cargo essa importante tarefa. (REVISTA DO IHGB. t. I, 1839, Sessão Pública Aniversária - p. 282).

A “cor" dos novos tempos era a expressão do triunfo monárquico, o qual resultava de uma expansão para dentro, ao mesmo tempo que a pressupunha. Nela, o IHGB, o Imperial Colégio de Pedro II e inúmeras outras instituições culturais, práticas culturais diversas e, sobretudo, textos literários de diferente natureza serviam para "explicar" a pátria, de modo que "aproveitassem a todos os Brasileiros". E aquele movimento de uma expansão singular gerava textos como o Compêndio e Lições. 
Ora, "todas as nações existiram anos e séculos antes de possuírem uma literatura própria"; todavia, no momento em que passava a existir, uma literatura nacional não era senão a expressão do "caráter nacional", ao mesmo tempo em que contribuía para uma melhor definição deste, em um momento próprio de uma trajetória histórica. A literatura, a história e a língua nacionais em constituição eram as grandes narrativas que propiciavam a constituição de um todo homogêneo - a Nação moderna, ocupando um território delimitado: o Estado nacional. A seu modo, como expressão de suas próprias experiências, Abreu e Lima o percebia; seu modo particular, embora não exclusivo, de perceber o papel dos elementos constitutivos de um movimento fundamental, revelava-se ao dizer, por exemplo, que "na literatura propriamente dita tem o primeiro lugar a história”.

Tais narrativas não deveriam cumprir um papel diverso no Império do Brasil. Contribuindo para forjar um "sentimento nacional", no mesmo movimento em que o difundia, elas iam conformando a "mocidade Brasileira". Ora, já o sabemos, o Estado nacional que ia se constituindo no mesmo movimento em que eram constituídos os brasileiros, era o único Estado de um Império, ao passo que a Nação brasileira também em constituição optara por conviver com o que denominava "outras nações" em um mesmo território. Deste modo, aquelas narrativas - dentre elas, o Compêndio da História do Brasil - apresentavam-se como instrumentos fundamentais no movimento de uma expansão para dentro. Como se fossem espelhos, nelas os brasileiros se deveriam mirar. Porque ao fazê-lo tinham a possibilidade de identificar o que os assemelhava, os diferenciava e, em certos aspectos, os tornava superiores a seus olhos aos habitantes das "Nações civilizadas" (Cf. MATTOS, 2003, p. 9-17); tinham ainda a possibilidade de vivenciar cotidianamente o que distinguia a Nação brasileira à qual pertenciam das demais "nações" com as quais tinham optado por conviver no território do Império do Brasil, e que necessariamente também inventavam.

Como um espelho particular, Compêndio encontrava o seu lugar e papel em uma expansão para dentro. Sua longa e ambígua trajetória, como que a exemplificar a trajetória de vida de Abreu e Lima, revelavam a cada nova edição os inúmeros leitores que conferiam prestígio e honra a seu autor. 


\section{EDITORES E EDIÇÕES: UM JOGO DE INTENÇÕES}

A importância, o valor e até mesmo as polêmicas que suscitou garantiriam uma longa trajetória ao livro de Abreu e Lima. Às razões de uma longa trajetória devem ser acrescentadas, sem sombra de dúvidas, o papel dos editores, embora nem sempre lhe tenha sido dado o destaque devido.

Tento recuperar algumas das ações empreendidas pelos Laemmert, começando pela edição inicial. Tenho em mãos o segundo tomo da primeira edição. Nele, chama a atenção do leitor, de imediato e de modo quase inevitável, os capítulos Sétimo e Oitavo, dedicados às épocas que se estendem de 1821 a 1831 e de 1831 a 1841, respectivamente, os quais se estendem por 138 páginas; a eles sucede um Índice chronológico da história do Brasil, que se estende da página 139 até a página 170. Em uma espécie de Anexo, com numeração própria de páginas, encontram-se "Documentos em apenso ao Compêndio da História do Brasil", ocupando 188 páginas, e o "Índice das Matérias contidas no segundo volume”. Mas, o tomo não se encerra aí. Nas páginas seguintes, também com numeração própria, aparece uma "Lista dos Senhores Subscriptores"; em seguida, o que poderíamos chamar de um anúncio do próximo livro de Abreu e Lima - um Compêndio da História Universal. Desde a mais remota Antigüidade até aos nossos dias, com local e data: "Rio de Janeiro, 10 de agosto de 1843"; e, por fim, um “Aviso ao Encadernador", referente à "colocação das estampas” em cada um dos tomos.

Começo pelos "subscriptores". Os nomes de mais de 1.000 deles apareciam arrolados, por ordem alfabética, ao longo de 31 páginas. Alguns, não poucos, seguidos de títulos que melhor os identificavam e distinguiam - "Dr", "Dezor.", "Padre", "Exmo.", "Veador", "Exmo. Conselheiro", "Vigário", “Major", "Desembargador", "Cônego”, “Senador", "Coronel", "Padre Mestre", "Bacharel", "Ten.Corel.", "Brigadeiro", "Comandante de Artilharia", "Comendador", "Fr.", "Alferes", “Advogado", “Tenente”... Outros, a maioria, apenas com seus nomes; umas poucas mulheres; um "Miguelista"; e alguns "Anonymos"... Nomes como o de José Joaquim de Lima e Silva, Luiz Pedreira do Couto Ferraz, Marquês de Baependi, Domingos José Gonçalves de Magalhães, Rafael Tobias de Aguiar, José Maria da 
Silva Paranhos, Marquês de Maricá, Joaquim de Souza Breves, Joaquim Gonçalves Ledo, Tristão de Alencar Araripe, Antônio Pedro de Figueiredo, Felipe Patroni Maciel Parente, Luiz Augusto May, Lopes Gama, Paulo Fernandes Vianna, Sebastião do Rego Barros, Conrad Jacob de Niemeyer, José Martiniano de Alencar, Martim Francisco Ribeiro de Andrade, Justiniano José da Rocha (poderia ele deixar de ser um "subscriptor"?) e quantos mais... revelavam o prestígio do autor e a curiosidade que a obra despertava. Pertenciam todos, certamente, à boa sociedade imperial. Residiam na Corte em sua grande maioria; mas àqueles que estavam nas províncias, a comunicação a vapor que desde 1839 unia as províncias marítimas à Corte facilitava o acesso aos produtos culturais desta emanados, ao mesmo tempo que sufocava a atividade editorial e impressora nas províncias em proveito das casas editoriais e tipográficas da sede imperial. Nomes que - longe de representar a "mocidade Brasileira" garantiam ao autor o sucesso da edição. E também aos editores!

Outra talvez não era a expectativa dos editores. Afinal, tinham se esforçado para tanto, quer buscando subscritores, quer afirmando de modo enfático as qualidades do autor, ainda que por caminhos indiretos. Ora, naquilo que identificamos como uma espécie de "anúncio" do próximo compêndio de Abreu e Lima eram destacadas as qualidades de historiador do autor, as quais evidentemente não podiam deixar de estar presentes na formação de Compêndio. Ali vinha dito, a respeito do Compêndio de História Universal, que

nesta obra só o plano de outro autor, o do célebre historiador Bredow, foi inteiramente seguido; todo o mais trabalho e mais custoso é inteiramente novo, e, apesar de árduo, bem acabado. O autor, ajudado dos dotes de verdadeiro historiador, que sobejamente possui, extratou dos melhores escritores o bom; verificou o duvidoso; emendou o errado; e acrescentou muita informação, principalmente sobre a América, que ele próprio em suas viagens colheu, e guardou com apurada crítica.

Um recurso inteligente permitia atribuir valores positivos a ambos os compêndios ao apresentar com destaque a avaliação do autor comum - um "verdadeiro historiador". Uma avaliação que, no que se refere a Compêndio, antecipava-se à avaliação pelo IHGB. 
Todavia, o sucesso positivo da primeira edição parecia pouco para os editores, tendo em vista suas intenções. No mesmo ano de seu lançamento, uma segunda edição de Compêndio veio à luz. Ela não era uma simples reimpressão. A primeira edição - não custa recordar - era apresentada em dois tomos; o texto principal era constituído por uma "Introdução" e oito capítulos ou "épocas", complementado por alentadas notas de pé-depágina e a transcrição de inúmeros documentos; sete "estampas" ou retratos davam relevo a personagens (cinco no primeiro tomo: "D. Pedro I, no frontispício"; "Cristóvão Colombo, em frente da pag. XVI da introdução"; "Cabral, em frente da pag. XX da introdução"; "Camarão, em frente da pag. 170"; e "Henrique Dias, em frente da pag. 184"; e outras duas no segundo: "D. Pedro II, no frontispício"; e "José Bonifácio, em frente da pag. 20”, de acordo com o “Aviso ao Encadernador”), além de um Índice cronológico detalhado. A segunda edição, por sua vez, aparecia em um único volume, de 359 páginas, sem muitas das notas da edição anterior (de um total de 99 notas, apenas 17 permaneceram) e sem os documentos. De modo a assinalar de modo expressivo as diferenças entre ambas as edições do mesmo ano, os editores apresentaram-nas por meio de uma "Advertência", que não mais deixava dúvidas a respeito de suas intenções:

Advertência

Publicamos a presente edição do Compêndio da História do Brasil, pelo General José Inácio de Abreu e Lima, dedicado a S.M.I. -, por julgarmos que uma edição em forma pequena concorrerá muito para vulgarizar a sua literatura, principalmente pela comodidade do preço, pois formando esta obra dois grossos volumes, pelas muitas Notas e Documentos, e com sete Estampas muito finas, necessariamente havia de ter um preço subido e por conseqüência menos acessível; também julgamos mais adequadas para os COLÉGIOS e para toda a Mocidade Brasileira uma edição, que pelo volumoso não intimidasse os jovens leitores; e assim suprimiram-se nesta todas as Notas não absolutamente indispensáveis, e todos os Documentos; o que, sem diminuir a profícua instrução que a Mocidade deve colher sobre a História pátria, abrevia um pouco a leitura, torna o livro mais manual e diminui consideravelmente esta indispensável despesa.

Os Laemmert 
As intenções dos editores eram claras: ampliar o número de leitores de uma obra que se mostrava promissora. E esperavam alcançá-lo tanto barateando o seu custo quanto procurando tornar mais acessível e fácil sua leitura por um número maior de "jovens leitores" - exatamente nesta ordem. Definiam-se nitidamente as relações entre autor e editor, sob os olhos vigilantes do imperador a quem a obra - e os editores não se furtavam de dizê-lo com todas as letras - era dedicada.

A busca pelos editores de um público-leitor diverso e até certo ponto novo constituía tarefa árdua, a começar por seu número ainda extremamente restrito. De acordo com Laurence Hallewell, em 1847 apenas 1.352 crianças estavam matriculadas nas 25 escolas públicas da cidade do Rio de Janeiro, das quais oito eram para meninas, e mais ou menos quatro mil em escolas privadas, em uma população total em idade escolar de 14.300 crianças. O quadro não era muito diverso em Minas Gerais: 5.853 crianças em escolas primárias públicas, 233 em escolas privadas e 345 em escolas secundárias. Já em Pernambuco, existiam 80 professores primários (dos quais 64 eram homens) e apenas 7 professores secundários (HALEWELL, 1985, p. 144). ${ }^{39}$ Todavia, a adoção da nova edição no Imperial Colégio de Dom Pedro II parecia compensar os seus esforços desenvolvidos no sentido de uma adequação, sobretudo caso consideremos o valor e o peso simbólicos daquela adoção. Ali, o Compêndio da

História do Brasil só encontraria concorrente nas Lições de História do Brasil de Joaquim Manuel de Macedo, editadas entre 1861 e 1863. De modo consciente, os editores contribuíam para a criação de uma nova categoria de livros, no movimento contraditório daquilo que alguns já denominaram de "nascimento da escola moderna" no mundo ocidental. ${ }^{40} \mathrm{E}$ faziamno por meio de uma intervenção deliberada, que não deixaria de marcar as relações que entretinham com o autor.

Ora, de acordo com Abreu e Lima, a intervenção dos editores, por ele acatada, e da qual resultaria a segunda edição da obra no mesmo ano de 1843 , não fora a primeira. Ao

\footnotetext{
${ }^{39} \mathrm{O}$ autor retirou seus dados do Annuario político histórico e estatístico do Brasil para 1847, de Firmin Didot. Ao observar serem aqueles os dados mais antigos obtidos por ele sobre a educação brasileira, não deixa de constatar serem os mesmos, "infelizmente, muito incompletos".

${ }^{40} \mathrm{Cf}$., entre muitas outras possibilidades, Lehembre (1989).
} 
responder a uma das críticas feitas por Varnhagen no "Primeiro Juízo", a respeito das sete estampas ou retratos que ilustravam a obra, Abreu e Lima recorda que "a lembrança dos retratos não foi minha, mas dos editores". Como é sabido, imagens sob a forma de estampas ou outra qualquer era coisa pouco comum em livros editados no Império, em meados do século XIX, bastando lembrar que as Lições de Macedo, editadas dezenove anos mais tarde e sob os auspícios do IHGB, não as possuía.

Embora sustente ter aprovado a introdução das estampas, havia ficado desgostoso com o anacronismo produzido pelo desenhista: "só senti que no vestuário se não tivesse guardado a verossimilhança pelo daquela época e não de um século depois" (ABREU E LIMA, 1844, p. 36). Todavia, a insatisfação do autor não fora suficiente para que uma correção da indumentária dos personagens fosse efetuada.

Assim, os retratos para a edição em dois tomos foram propostos pelos editores; e por eles também retirados da edição seguinte, conforme visto há pouco. De qualquer modo, não é improvável que o autor não apenas tenha aprovado a idéia dos Laemmert, mas também participado da escolha dos personagens a serem representados, os quais deveriam compor um panteão nacional.

É interessante observar como alguns dos retratos - como é o caso daquele de Henrique Dias - permaneceriam sendo considerados, pelos tempos afora, representações historicamente adequadas e escolhidas pelo autor, e assim considerados "verdadeiros". Em Governador dos negros, criolos e mulatos, Hebe Mattos ressalta o fato de Abreu e Lima antecipar, no que a autora julga ser o "primeiro Manual de história do Brasil", a "representação do comandante negro que se tornaria predominante até bem avançado o século XX”. Uma antecipação que escapava ao silêncio então prevalecente, "já que durante o período monárquico a presença africana na formação do povo brasileiro foi preferencialmente silenciada na maioria das representações oficiais" (MATTOS, 2006, p. 72-76).

O papel representado pelos Laemmert pode ser avaliado ainda pela leitura da parte final da Resposta ao Primeiro Juízo, redigida por Abreu e Lima. Nela, ao responder ao questionamento irônico feito por Varnhagen a respeito de uma possível contribuição de 
Compêndio para a melhoria "[d]o estado (nem por isso tão feio) em que nos achávamos", Abreu e Lima argumenta de modo também irônico, recorrendo a uma recordação:

[...] Não sei se melhoramos, nem a mim cabe dizê-lo; porém o que posso asseverar-lhe é que os editores disseram uma verdade, que o mesmo Sr. Varnhagem acaba de confirmar. Era doloroso ver, dizem os editores, que a História do Brasil se tivesse tornado uma especulação estrangeira (ABREU E LIMA, 1844, p. 117).

Ironias à parte (não é possível esquecer que, por ser filho de estrangeiros, Varnhagen era considerado por muitos um estrangeiro), os indícios a respeito da participação dos editores em diferentes momentos da história de Compêndio permitem perceber uma faceta de Abreu e Lima nem sempre valorizada por seus contemporâneos: a abertura ao diálogo, reveladora de uma cordialidade. Ainda assim talvez seja importante não esquecer que o acréscimo das estampas proposto pelos editores em nada alterava a intenção de Abreu e Lima, talvez mesmo a reforçasse, uma vez que a obra permanecia guardando, antes de tudo, o caráter de "epítome, resumo do mais substancial, ou das noções elementares de alguma arte, ciência, ou preceitos", de acordo com a definição de Moraes e Silva, o que permitiria ao seu autor estar no IHGB. Já as substrações levadas a cabo pelos Laemmert para a $2^{\mathrm{a}}$ edição, dando ao livro, por metonímia, o caráter de "livro, esp. escolar, que enfeixa tal resumo < um c. de geografia >", de acordo com Houaiss, iam ao encontro das intenções destes - isto é, dos editores, os quais passavam a "estar mais próximos dos colégios". Ora, deste jogo de intenções, a um só tempo complementares e contraditórias, resultaria algo incomum: tendo tido duas edições no ano de seu lançamento, a Compêndio eram atribuídas intenções diversas em cada uma delas. Se aos editores interessava um livro escolar - ou um "compêndio para a instrução pública”, como algum tempo depois se tornaria comum dizer, que pressupunha um leitor específico, o aluno , esta não era a intenção ou preocupação do autor, razão por que talvez seja necessário guardar certa cautela ao se atribuir a Abreu e Lima a autoria do primeiro livro didático de História do Brasil.

Ainda que afirme que "antes quis passar por simples cronista do que por historiador", Compêndio e seu autor tiveram reconhecidos o seu lugar por um avalidador rigoroso e 
insuspeito. Ao fazer o necrológio de Francisco Adolfo de Varnhagen, o cearense Capistrano de Abreu afirma que a História Geral do Brasil do sorocabano só era inferior à História do Brasil de Southey; para acrescentar, logo em seguida: "nenhum brasileiro lhe pode atualmente ser comparado". Assim, abaixo de Varnhagen situavam-se Pereira da Silva, Melo Morais e Abreu e Lima no panteão dos formadores dos "estudos históricos" no Brasil. Do último diria Capistrano de Abreu: "Abreu e Lima é um compilador, inteligente, é verdade, mas já antiquado quando apareceu sua obra, muito mais agora que sobre ela passaram mais de quarenta anos de estudos históricos" (ABREU, 1975).

Mas, quem eram esses editores que com suas intenções atribuíram um valor diverso a um livro? Dos dois irmãos Laemmert, Eduard foi o primeiro a chegar ao Brasil, enviado pelo editor Bossange, com quem trabalhava em Paris havia mais ou menos dois anos. Aos 21 anos de idade, aquele que era natural do grão-ducado de Baden chegava ao Rio de Janeiro com a incumbência de estabelecer uma filial. "Esta viria a ser uma sociedade entre Eduard Laemmert, representando Bossange, e um português chamado Souza, representando J. P. Aillaud" (HALLEWELL, 1985, p. 161), um outro editor-livreiro francês. Desde então, e até o término do contrato em 1833, ele foi o responsável pelo andamento dos negócios daquela editora na Corte. Interessado em continuar a viver no Brasil, Eduard tomou a resolução de se casar e fixar residência na capital do Império, iniciando seu próprio negócio: a Livraria Universal, situada na rua da Quitanda, $n^{0} 77$. Ao mesmo tempo, passou a insistir junto ao irmão para que também viesse para o Brasil, o que teria acontecido por volta de 1835. Três anos depois, ambos inauguravam uma nova sociedade - "Eduard e Heinrich, mercadores de livros e música". Naquele mesmo ano, Eduard já havia inaugurado sua própria tipografia - a Typographia Universal -, na rua do Lavradio, $n^{0} 53$.

O sucesso do empreendimento foi quase imediato, a maioridade da firma quase coincidindo com a maioridade do segundo imperador. Os Laemmert - ou Eduardo \& Henrique, como já aparecia nas folhas de rosto de suas publicações - ganhavam fama e dinheiro como livreiros e editores. Além de publicar livros, "guias de bolso e outras publicações semelhantes, produzidas rapidamente para atender à demanda do mercado", de acordo com Hallewell, eles passaram a editar, desde 1839, uma Folhinha anual, e, a partir de 1844, o Almanack administrativo, mercantil e industrial da corte e província do Rio de 
Janeiro, o qual muito rapidamente passou a conter informações de todo o Império, tornandose o famoso Almanack Laemmert (HALLEWELL, 1985, p. 162-163).

Durante o denominado "apogeu do Império", os Laemmert só encontrariam rival em um outro editor e livreiro: Baptiste Louis Garnier. Em fins dos anos 70, as livrarias de ambos situavam-se na rua do Ouvidor, uma quase em frente à outra. ${ }^{41}$ Se recupero aqui a figura de B. L. Garnier - “o Bom Ladrão Garnier”, conforme gostavam de brincar os contemporâneos - é porque um episódio de sua vida contribui para a minha argumentação. Ao requerer ao Governo do Império a concessão do título de oficial da Ordem Imperial da Rosa, o qual acabou por obter em 1867, aquele que já era tanto o mais importante dos editores do Império do Brasil quanto o principal editor de livros escolares sublinhava em sua petição, entre outros serviços, o fato de "muitos autores de diversas obras, e compêndios para a instrução pública [...] têm encontrado no peticionário auxílio eficaz para a realização de suas publicações" (HALLEWEEL, 1985, p. 125, grifo meu).

Destaco o fato de Garnier apresentar-se como editor de compêndios para a instrução pública. Ora, por sua função como um adjunto restritivo, a expressão "instrução pública" demarcava, naquela oportunidade, um sentido diverso para a palavra "compêndio", entrevisto já nas intenções dos Laemmert em 1843, embora não enunciado. Ela indicava algo novo, que ultrapassava a constatação referida à existência de uma mercadoria nova. E a indicava ao mesmo tempo em que revelava como os compêndios para a instrução pública eram também um dos fatores constitutivos de um movimento fundamental. ${ }^{42}$ À semelhança das "Nações civilizadas", também no Império do Brasil a constituição de um corpo político moderno, assim como dos sujeitos que ele contém, pressupunham a "escola moderna", e tudo aquilo que lhe diz respeito, aí incluídos os manuais escolares - ou seja, compêndios para a instrução pública.

\footnotetext{
${ }^{41}$ Foi em fins dos anos 60 que a Livraria Universal fora transferida para ali, ao passo que a tipografia do mesmo nome mudara para a rua dos Inválidos.

42 "Defendo a hipótese de que todo conceito é sempre concomitantemente Fator (Faktor) e Indicador (Indikator). Todo conceito é não apenas efetivo enquanto fenômeno lingüístico; ele é também imediatamente indicativo de algo que se situa para além da língua" (KOSELLECK, 1993, p.136).
} 
Um movimento que revelava sujeitos, representações e práticas novos, ao mesmo tempo que transformava outros mais antigas - professores, alunos, inspetores; prédios e manuais escolares; autores, editores e leitores. Um movimento que forjava palavras e expressões novas, e ressignificava outras. É o caso de didática: derivada do francês didactique - "que visa a instruir, que se relaciona ao ensino", da qual derivaram as expressões didactiquement e didactisme em 1754 e 1860, respectivamente, de acordo com o Robert -, ela teria sido incorporada à língua portuguesa entre o final do Primeiro Reinado e o início do governo pessoal do segundo imperador (LE NOUVEAU PETIT ROBERT, 1993, p. 640). ${ }^{43} \mathrm{O}$ certo é que a palavra que designava a "ciência ou arte de ensinar" não era ainda suficientemente forte e nem se encontrava vulgarizada entre os letrados do Império do Brasil, ao tempo da petição de B. L. Garnier, para caracterizar ou denominar um produto novo: havia compêndios para a instrução pública; não existiam ainda livros didáticos. ${ }^{44}$

A nova "arte de ensinar" só seria assimilada pelos editores de Compêndio em sua quinta edição, em 1882. Feita após a morte de seu autor, tal assimilação tardia talvez fale também a respeito do próprio autor. ${ }^{45}$

\footnotetext{
${ }^{43}$ De acordo com Houaiss foi em 1828 que a palavra foi incorporada à língua portuguesa (cf. HOUAISS, 2001, p. 1036); para Antonio Geraldo da Cunha, tal teria ocorrido em 1844 (CUNHA, 1986, p. 263).

${ }^{44}$ Alain Chopin observa que "se hoje consideramos o livro didático como um objeto banal, um objeto tão familiar que parece inútil tentar defini-lo, o historiador que se interessa pela evolução dos livros escolares - ou das edições escolares - depara, logo de início, com um problema de definição" (CHOPIN, 2004, p. 549-566). Ainda que considere pertinentes as instigantes considerações do autor, não me preocupa definir o que é um "Iviro didático", hoje ou ontem. Parto do princípio de que os autores que se dispõem a produzir um texto didático sabem o que pretendem fazer e como devem fazê-lo, o mesmo podendo ser dito a respeito dos professores que se dispõem a adotar um livro didático. Em outras palavras, proponho que se busque nas intenções de autores e professores, evidentemente com pontos em comum e diferenciados, os elementos que permitem identificar uma obra como didática, e o que se entende por tal em determinado momento e circunstância. Assim, o surgimento da palavra "didática" entre nós não significa o surgimento de livros didáticos de imediato, necessariamente. Conforme ensina L. Febvre, "não, a definição teórica não é de grande ajuda para nós, historiadores. Ela só existe, a bem dizer, fora de nossos estudos. O que vale para nós é a história da palavra, e feita com precaução. Saber se tal palavra é antiga na língua ou que, ao contrário, ela só surgiu recentemente [...] uma palavra não data sempre, não data necessariamente de sua primeira aparição em um texto [...] toda língua conta com palavras, numerosas e importantes, que precisaram de décadas, senão de séculos, para carregar-se de sentido" (FEBVRE, 1998, p. 29).

${ }^{45}$ Guiando-me pelas informações fornecidas pelos biógrafos de Abreu e Lima, assim como por aquelas oferecidas por pesquisadores dedicados ao estudo do ensino da história no Brasil, concluo que foram cinco as edições de Compêndio, das quais quatro ainda em vida do autor. Foram todas feitas pelos mesmos editores, no século XIX. Todavia, nenhum deles apresenta a data da terceira edição, sendo a quarta datada de 1852: ambas teriam mantido o mesmo formato in $-8^{\circ}$ e um só volume. Talvez seja importante dizer que, exceptuadas as duas primeiras edições, não encontrei qualquer evidência documental que permita afirmar a participação ativa de Abreu e Lima após as duas edições iniciais, o que me faz crer terem sido elas de responsabilidade exclusiva dos editores.
} 
Trinta e nove anos depois da primeira edição, apareceria aquela que seria a última edição de Compêndio. Tudo leva a crer que os responsáveis pela editora avaliassem que, na pior das hipóteses, pelo menos na província de Pernambuco a obra de Abreu e Lima alcançaria público significativo. Uma outra "Advertência" apresentava a quinta edição, cujo título fora adaptado para Compêndio da História do Brasil pelo General José Inácio de Abreu e Lima. Nova edição mais correta e continuada até nossos dias. ${ }^{46}$

\begin{abstract}
Advertência
Oferecemos ao público uma nova edição do Compêndio de História do Brasil, do general José Inácio de Abreu e Lima dedicada a S M o Imperador. Era primeiramente este Compêndio, uma obra em 2 volumes, ornada de 7 estampas finas e repleta de notas e documentos destinados a corroborar as asserções contidas no texto, e não podia, quer por causa do tamanho, quer por causa do preço, aspirar à circulação que tínhamos em vista conciliar em proveito da divulgação da história pátria.

Como desejássemos tornar o conhecimento do passado do Brasil acessivo ao público em geral, e principalmente à mocidade estudiosa, tratamos de organizar, sob o ponto de vista didático, o livro atual, que sem omitir fato algum importante, torna-se recomendável pela exposição clara e concisa de todos os acontecimentos que se deram no Brasil. Reduzindo o formato pela supressão dos documentos e notas, que não afetam a exposição da doutrina, foi nos possível realizar uma extraordinária redução do preço, que sobremodo aproveita aos pais de família e aos colégios.

Uma outra circunstância, para a qual chamamos a atenção do público, é a continuação da exposição histórica até os nossos dias, confeccionada por um distinto literato nacional. Era uma lacuna geralmente observada em todos os Compêndios de história pátria que quando muito atingiram o período regencial e a inauguração do reinado atual. Podemos afirmar que é a $1^{\mathrm{a}}$ vez que um livro escolástico se depara com a narração breve e concisa dos feitos memoráveis que assinalam o longo e próspero reinado de S. M. O Sr D. Pedro II.
\end{abstract}

Os editores

\footnotetext{
46 “A nova edição mais correta e continuada até nossos dias” possui 431páginas.
} 
Se, à primeira vista, a nova "Advertência" parece apenas reproduzir os argumentos mais significativos da segunda edição, uma leitura mais atenta permite constatar algo mais.

A palavra surgida recentemente na língua portuguesa - didática - marcava sua presença de modo contundente na edição de 1882, sob a forma de uma pretendida associação entre um "livro escolástico" e a apresentação da narrativa histórica "sob o ponto de vista didático". É difícil saber se, interessados em realizar uma atualização e uma adequação, os editores percebiam a incompatibilidade entre aquele que, de acordo com suas intenções e ações, se tornara um compêndio para a instrução pública e a nova intenção de apresentá-lo como um texto organizado "sob o ponto de vista didático". Por certo outras razões podem ser identificadas, mas nesta incompatibilidade reside, em larga medida, a razão por que o Compêndio da História do Brasil de Abreu e Lima foi abandonando a companhia da "mocidade Brasileira" para se juntar aos textos formadores da história pátria, de acordo com o juízo de Capistrano de Abreu, no final do século XIX. Após uma longa trajetória, a intenção original do autor de Compêndio parecia ser restaurada.

Mas é chegada a hora de falar de um outro personagem: o encadernador. O "Aviso ao Encadernador" que aparece no final do segundo tomo de Compêndio revela uma circunstância completamente estranha a nós, hoje: nos livros de então, as estampas e gravuras não eram impressas ao lado do texto, e sim reproduzidas em folhas individuais e soltas, que deveriam ser inseridas no livro pelo encadernador posteriormente, não raro após a venda. $\mathrm{O}$ "Aviso" do editor revela não só o ofício do encadernador, mas também sua situação entre as intenções do autor e do editor, expressas aqui no local indicado para cada uma das estampas. E ainda algo mais.

As pesquisas no IHGB, no NUDOM - Núcleo de Documentação e Memória do Colégio Pedro II - e na Biblioteca Nacional, assim como um volume recebido como presente, acrescentaram novas informações a respeito das edições, permitindo algumas correções dos dados existentes, além de propor uma espécie de enigma. 
Sob a forma de um presente ofertado por uma colega de ofício, chegou-me às mãos um exemplar do primeiro tomo, também datado de 1843. Ele logo despertou minha atenção por apresentar no frontispício D. Pedro II, no lugar que deveria ser ocupado por seu pai, e por não apresentar qualquer outro dos cinco retratos no corpo do texto. E mais do que isso: o retrato do segundo imperador já não era o do jovem de 18 anos que figurava na abertura do segundo tomo da edição princeps, e sim a de um D. Pedro já homem maduro, muito provavelmente às vésperas da Guerra do Paraguai. Ao que se apresentava como um enigma, duas possibilidades de resolução ao menos se ofereciam: ou a data da edição não era exata, a presumível nova edição reproduzindo simplesmente a folha de rosto da edição original, algo pouco provável porque somente naquele ano fora feita uma edição em dois tomos, ou o novo retrato fora acrescentado posteriormente por meio da encadernação na edição original. Se enigmas existem para serem resolvidos, decidi-me por cotejar cuidadosamente o exemplar que me fora presenteado com os existentes no IHGB, no NUDOM e na Biblioteca Nacional, tendo concluído serem todos idênticos no que refere ao texto principal, sem qualquer alteração quer nas edições em um ou dois volumes, quer em 1843 ou em 1852. Se a segunda hipótese parece se impor, a situação do encadernador se desloca, pondo em relevo agora a relação entre o texto (isto é, o autor) e o leitor. Fora deste muito provavelmente a decisão de proceder a uma substituição, por certo não no momento da edição do texto em 1843, e sim em outro bem posterior, quando o triunfo da ordem imperial talvez já se mostrasse de modo pleno, expressando-se na entronização da imagem serena de "O Senhor D. Pedro II. Imperador Constitucional e Defensor Perpétuo do Brasil", conforme a legenda. A homenagem ao imperador não partia nem do autor nem do editor, e sim de um leitor. No fundamental, a homenagem prestada sob a forma de uma estampa colocada em posição de destaque por decisão de um súdito brasileiro de D. Pedro II indicava o triunfo de uma expansão para dentro, ao mesmo tempo em que dela permanecia sendo um fator constituinte.

Tive em mãos outros exemplares da edição em dois tomos. Tendo examinado cada um deles cuidadosamente, posso afirmar serem todos da mesma edição original: o texto é o mesmo, página a página; como não poderia deixar de ser, são os mesmos os cadernos gráficos, cuja numeração aparece de modo quase imperceptível ao pé da primeira página de cada um deles; e são os mesmos os endereços da editora e da tipografia, anteriores às mudanças de local já referida. Mas há diferenças entre eles, instigando a imaginação. Em um 
dos exemplares, o retrato de D. Pedro II que deveria abrir o segundo tomo da primeira edição foi deslocado para a abertura do primeiro tomo, e o seu lugar original preenchido por um outro retrato do imperador, já idoso, com longa barba branca. Nele ainda, as demais imagens e a dedicatória ao segundo imperador foram suprimidas. Diferenças que dão destaque ao ofício do encadernador; todavia, é pouco provável que este agisse por decisão própria. Instrumento também de uma censura, pois era contrariada a intenção do autor de homenagear o primeiro imperador, o encadernador revelava muito provavelmente a intenção de um leitor, o qual ao determinar a reordenação e/ou exclusão das estampas demonstrava plenamente, também neste caso, o alcance de uma expansão para dentro.

Mas o que não deixa de chamar a atenção é que o resultado de uma expansão para dentro não implicava, ao menos no caso particular da escrita e do ensino da história pátria, na adoção irrestrita dos pressupostos estabelecidos pelo IHGB. Afinal, como é sabido, as sucessivas edições de Compêndio não incorporaram as críticas feitas por Francisco Adolfo de Varnhagen no Primeiro Juízo redigido por solicitação do IHGB.

A recepção de Compêndio evidencia, assim, as idiossincrasias e tensões existentes no interior da boa sociedade imperial não só no início dos anos 40. Bastaria lembrar que, pelo menos até o surgimento de Lições de Macedo, Compêndio obteve uma aceitação bem mais expressiva do que tem sido considerado por grande parte dos pesquisadores. E ainda que a última edição do livro de Abreu e Lima ocorreu vinte e um anos após a primeira edição de Lições.

Assinalada por aplausos e censuras, a trajetória de Compêndio revelava o prestígio de seu autor e o público-leitor que cativava. A muitos Compêndio se apresentava talvez como uma compreensão alternativa da História do Brasil em produção e divulgação pelo IHGB. Como que numa espécie de prova do que insinuo, nesta oportunidade, aparece a Synópse ou dedução cronológica dos fatos mais notáveis da História do Brasil, também de autoria de Abreu e Lima, editada em 1845. Ela consta da lista dos livros aprovados pelo Presidente da Província de Pernambuco, no Edital do Diretor Geral da Instrução Pública, publicado em 5 de agosto de 1851 no Diário de Pernambuco. Ou seja, após a derrota dos praieiros! 
QUADRO I

EDIÇÕES DE COMPÊNDIO DA HISTÓRIA DO BRASIL*

\begin{tabular}{|c|c|c|c|c|c|c|c|}
\hline Edições & \multicolumn{7}{|c|}{ Partes } \\
\hline $\begin{array}{c}1843 \\
2 \text { tomos }\end{array}$ & & Prefácio & Introdução & $\begin{array}{c}\text { Capítulos } \\
\text { (com Notas e } \\
7 \text { imagens) }\end{array}$ & $\begin{array}{l}\text { Índice } \\
\text { cronológico }\end{array}$ & $\begin{array}{l}\text { Documen- } \\
\text { tos em } \\
\text { apenso }\end{array}$ & $\begin{array}{l}\text { Índice } \\
\text { geral }\end{array}$ \\
\hline $\begin{array}{c}1843 \\
1 \text { tomo }\end{array}$ & $\begin{array}{l}\text { Adver- } \\
\text { tência }\end{array}$ & Prefácio & Introdução & $\begin{array}{c}\text { Capítulos } \\
\text { (com parte } \\
\text { das Notas e } \\
\text { sem imagens) }\end{array}$ & $\begin{array}{l}\text { Índice } \\
\text { cronológico }\end{array}$ & & $\begin{array}{l}\text { Índice } \\
\text { geral }\end{array}$ \\
\hline $\begin{array}{c}1852 \\
1 \text { tomo }\end{array}$ & $\begin{array}{l}\text { Adver- } \\
\text { tência }\end{array}$ & & Introdução & $\begin{array}{c}\text { Capítulos } \\
\text { (com parte } \\
\text { das Notas e } \\
\text { sem imagens) }\end{array}$ & $\begin{array}{l}\text { Índice } \\
\text { cronológico }\end{array}$ & & $\begin{array}{l}\text { Índice } \\
\text { geral }\end{array}$ \\
\hline $\begin{array}{c}1882 \\
1 \text { tomo }\end{array}$ & $\begin{array}{l}\text { Adver- } \\
\text { tência }\end{array}$ & & Introdução & $\begin{array}{c}\text { Capítulos } \\
\text { (com parte } \\
\text { das Notas e } \\
\text { sem imagens) }\end{array}$ & $\begin{array}{c}\text { Índice } \\
\text { cronológico }\end{array}$ & & $\begin{array}{l}\text { Índice } \\
\text { geral }\end{array}$ \\
\hline
\end{tabular}

* Não localizei a $3^{\text {a }}$ edição mencionada por quase todos os biógrafos de Abreu e Lima, embora o façam sem a indicação da data.

\section{O TEXTO}

Retorno ao Compêndio. Do "Prefácio" - doze páginas numeradas com algarismos romanos - passo ao que denomino "Texto principal" - a "Introdução" e os "Capítulos", ambos com enriquecedoras e alentadas notas de pé-de-página: são 464 páginas, distribuídas em dois volumes, das quais as oito referentes à "Introdução" estão numeradas também em romanos. O "Texto principal” é complementado, como já disse acima, por inúmeros documentos, que ocupam 192 páginas numeradas separadamente, com algarismos arábicos.

O "Prefácio" expõe as intenções do autor ao formar um compêndio, e o modo de fazêlo; o "Texto principal” é a sua concretização, particularmente nos "Capítulos". A utilização de diferentes tipos de algarismos para numerar o "Prefácio" e os "Capítulos" realça, por certo, os objetivos diferenciados que orientaram a redação de ambas as partes. Se considerado como um “compêndio para a instrução pública”, aquela diferença talvez possa ser interpretada como 
um alerta dos editores aos professores e seus alunos que o fundamental e principal daquele Compêndio se encontrava nas páginas numeradas com algarismos arábicos... - talvez! Mas, e a "Introdução"? Ela parece conter em si uma ambigüidade. Por ter suas páginas numeradas com algarismos romanos, e em sequiência às páginas do "Prefácio", ela parece compor um todo com este; todavia, a qualquer um que a tenha lido, valorizando o seu conteúdo substantivo, a tendência a aproximá-la mais dos "Capítulos" parece se impor. Será que argüir a respeito das razões por que ela não foi numerada com algarismos arábicos constitui uma falsa questão? Ao que talvez seja devido a um simples acaso, proponho uma explicação, a qual não atribuirá a razões de natureza editorial o papel principal. Para tanto ponho em destaque alguns trechos da "Introdução":

A Nação Portuguesa, fraca no princípio, chegou pela sua grande energia, e pela sabedoria de suas leis, ao mais elevado grau de poder a que era possível atingir, ficando triunfante e senhora absoluta de um imenso império cuja riqueza parecia convidá-la a gozar os atrativos do fausto e todos os gêneros de glória. O Monarca, os grandes e o povo, inflamados do amor dos descobrimentos e da sede de riquezas, assinalaram por empresas atrevidas os primeiros ensaios de navegação moderna, e com prodígios de valor souberam abrir caminho para todas as partes do mundo. (ABREU E LIMA, 1843a, p. xviii).

Toda a nação estava já preparada para grandes empresas, quando nos fins do décimo quarto século D. Fernando $1^{\circ}$, nono monarca, morreu sem deixar herdeiro masculino. A aversão dos Portugueses ao domínio de Castela favoreceu as intenções de D. João, irmão natural do rei”. (ABREU E LIMA, 1843a, p. xiv).

Desde este momento [a conquista de Ceuta, em 1415] começaram os Portugueses a conhecer a necessidade da navegação e dos descobrimentos $\mathrm{O}$ reinado de D. João I faz-se digno de contemplação, principalmente pelo impulso e movimento que o infante D. Henrique, digno filho deste monarca, dá ao espírito de sua nação para vencer preconceitos, que até então pareciam invencíveis ABREU E LIMA, 1843a, p. xiv). 
"Mudando assim o comércio do mundo, os descobrimentos de Colombo e Gama tiveram uma influência decidida sobre os destinos da espécie humana". (ABREU E LIMA, 1843a, p. xix).

Desde que se tratou de sustentar conquistas na África e na Ásia, o desejo de enriquecer, e o amor da glória, fizeram correr milhares de Portugueses às praias estrangeiras; desde logo suas armadas cobrem e dominam os mares da Índia. (ABREU E LIMA, 1843a, p. xx).

Já os Portugueses tinham dado o primeiro passo para o Oriente quando o acaso lhes deparou o domínio de uma das mais vastas regiões do hemisfério Ocidental, o BRASIL, que situado a mil e quinhentas léguas da Metrópole, em seu princípio desprezado, devia ser um dia, segundo a ordem eterna dos acontecimentos, o refúgio da monarquia portuguesa, a sede do seu poder, e um dos mais belos Impérios da América (ABREU E LIMA, 1843a, p. xx).

Os trechos da "Introdução" - na verdade, toda ela - são significativos; deles se destacam, ao menos, o que posso chamar de duas funções principais. A primeira procura estabelecer uma filiação ao pôr em evidência a trajetória da "Nação portuguesa", desde suas origens. O percurso narrativo é relativamente simples: "fraca no princípio", a "Nação portuguesa" havia muito "estava já preparada para grandes empresas", realizadas a partir da ascensão ao trono de D. João I, em fins do secúlo XIV; foi no transcurso da expansão marítima que, por um "acaso", os portugueses depararam com o Brasil, o qual "devia ser um dia, segundo a ordem eterna dos acontecimentos, o refúgio da monarquia portuguesa, a sede do seu poder, e um dos mais belos Impérios da América”. Ora, o estabelecimento de uma filiação apresenta-se como a condição para, em outra parte da obra - os "Capítulos" -, expor a trajetória de uma outra nação: “o BRASIL”. Por sua vez, estabelecer uma filiação implica em traçar uma linha de tempo - a linha de um tempo homogêneo e vazio -, na qual o autor situa, em uma das extremidades [o ponto de partida], "a Nação portuguesa, fraca no princípio”, e, na outra [o ponto de chegada], "um dos mais belos Impérios da América". Entre o ponto de partida e o ponto de chegada determinados pelo autor, são situados os eventos que deverão preencher aquele tempo vazio e homogêneo: os eventos da expansão marítima. Nela, “os descobrimentos de Colombo e Gama tiveram uma influência decidida sobre os destinos da 
espécie humana", assim como a Nação portuguesa tornou-se "senhora absoluta de um imenso império". Mas, nesta linha de tempo, dois acontecimentos singulares são valorizados pelo autor: um, obra do "acaso": o Descobrimento de "uma das mais vastas regiões do hemisfério Ocidental"; o outro, obedecendo à "ordem eterna dos acontecimentos", a vinda da Corte portuguesa para o Brasil. Uma filiação que, de imediato, reservava um "lugar" para o novo Império do Brasil no concerto das "Nações civilizadas" do continente europeu: - afinal, como punha em relevo o autor de Compêndio, pouco nos separava de Portugal, apenas "mil e quinhentas léguas" (curiosamente, o mesmo número do ano do Descobrimento).

Todavia, não era suficiente estabelecer apenas uma filiação; tornava-se necessário também revelar o que a qualificava. Assim, se a expansão marítima possibilitara uma filiação era porque fora ela animada pela atividade mercantil. No dizer de Abreu e Lima, se "os descobrimentos de Colombo e Gama tiveram uma influência decidida sobre os destinos da espécie humana" foi porque haviam mudado "o comércio do mundo". Eis a segunda das funções da "Introdução": atribuir um papel e valor positivos ao comércio e às relações mercantis na origem - e, conseqüientemente, na formação - de uma nova nação.

Observo, neste ponto, que na escritura da História do Brasil pela maioria dos autores do século XIX, relacionados de modo direto ou não às proposições do IHGB, e não apenas em Abreu e Lima, este papel e valor significativos atribuídos ao comércio e às relações mercantis estiveram sempre presentes. Em Compêndio como em inúmeros outros textos é a faina comercial que não apenas nos introduz na história como traça grande parte de nosso destino. Ambos, comércio e relações mercantis, nos tornam civilizados.

Papel e valor atribuídos às relações mercantis ao comércio na explicação da experiência histórica brasileira que decorriam do que Albert Hirschman denominou "a tese do suave comércio" (HIRSCHMAN, 1986). De acordo com Hirschman, a expansão do comércio e o desenvolvimento do mercado, do século XVI ao XVIII, geraram idéias e esperanças de que o comércio era um agente civilizador de considerável peso. Presente em O Espírito das leis - "o comércio [...] educa e suaviza os costumes bárbaros, como o vemos todos os dias", diz Montesquieu -, assim como em William Robertson, Condorcet e Thomas Paine, entre muitos outros, tais idéias e esperanças são aqui sintetizadas em dois pequenos trechos de uma 
obra citada por Hirschman. No Tratado geral do comércio, de Samuel Ricard, editado pela primeira vez em 1704, e inúmeras vezes reeditado nos oitenta anos seguintes, é possível ler: "o comércio liga os homens entre si por uma utilidade recíproca e silencia nele outras paixões morais e físicas para dar lugar ao interesse"; e também: "através do comércio, o homem aprende a refletir, a ter probididade e bons costumes, a ser prudente e reservado em seus propósitos e ações" (HIRSCHMAN, 1986, p. 15).

Enfim, para uma sociedade onde o mercado é fundamental para a satisfação das necessidades humanas, o homem buscará maneiras que facilitem o bom funcionamento do mercado, e com isso estará buscando um meio-termo para as opiniões divergentes, produzindo, assim, um homem "suavizado".

Ao que denomina de "tese do suave comércio", Hirschman contrapõe o que denomina a "tese da autodestruição". Esta procura sintetizar os argumentos daqueles para quem a sociedade de mercado, ao contrário das expectativas anteriores, minaria os fundamentos morais que servem de base para si própria; minaria o que foi herdado dos regimes anteriores porque os hábitos e costumes tradicionais fundados para o coletivo já não teriam tanto importância em um mundo movido pelo "interesse". Surgidos a partir do século XIX, tais argumentos sustentavam-se em três fatores: a primazia do interesse pessoal, dificultando a manutenção dos bens coletivos e a cooperação; o fato de os responsáveis pela política, que deveriam ser motivados mais pelo interesse geral do que pelo pessoal, não conseguirem fazêlo porque o sistema não possui um meio para desenvolver uma motivação para o geral, por ser fundado no interesse pessoal; e, finalmente, as virtudes sociais - veracidade, confiança, comprometimento -, necessárias para o funcionamento de uma economia contratual, são baseadas nas crenças religiosas, mas a base racionalista e individualista do mercado acaba por minar o sustentáculo fornecido pela religião.

Percorrer as páginas de Compêndio - desde a "Introdução" - é constatar como a "tese do suave comércio" fundamenta a narrativa de Abreu e Lima. Ali, as relações mercantis permitiam, como já foi salientado, estabelecer uma gênese e uma filiação por meio do acontecimento "Descobrimento do Brasil"; uma gênese e uma filiação que se renovam e atualizam quando "A Família Real chega ao Brasil". Mas aqueles papel e valor não se 
manifestaram apenas nestes dois acontecimentos singulares. Nesta oportunidade, limito-me a recuperar três outros exemplos, dentre vários, que revelam o papel atribuído àquelas relações: o primeiro deriva da associação entre paz e comércio, ao tratar da administração de Maurício de Nassau: "sendo a paz o melhor apoio do comércio, dirigiu o chefe batavo toda a sua atenção para os melhoramentos interiores" (I, 162); o segundo quando trata da ocupação da parte setentrional da colônia: "as Capitanias do Norte tinham recebido considerável aumento sempre protegidas pelas frotas, que de Portugal vinham anualmente comboiar os navios do comércio" (I, 212); e o último, ao tratar da instalação da Família Real portuguesa na cidade do Rio de Janeiro: "nenhum porto do mundo está mais bem situado para o comércio: tem uma entrada segura, e uma fácil saída, e parece destinado a ser o centro da cadeia que prende as relações entre as cinco partes do globo" (I, 256). Ora, esta última referência possibilita perceber, ainda uma vez, como o papel e o valor atribuído às relações mercantis permitiam reivindicar para o Império do Brasil um lugar de destaque no conjunto das "Nações civilizadas".

Por outro lado, as páginas de Compêndio revelam, desde os capítulos iniciais dedicados à colonização, como a transformação do "sertão" - uma designação que resultava da contração de "desertão", e que ganhara na experiência colonizadora portuguesa na América o significado de um espaço vazio de significações - em "América portuguesa" resultara de diversas práticas civilizatórias, decorrentes umas das relações mercantis e outras da ação missionária.

Responsáveis, em escala considerável, pelas classificações e imagens que contrapõem o "litoral" e ao "sertão", "civilização" e "barbárie", "cosmopolitismo" e "provincianismo", "economia mercantil" e "economia natural”, "progresso" e "atraso", entre inúmeras outras, como "Corte" e "roça", o papel e o valor atribuídos às relações mercantis sugeriam imagens e forjavam representações do Brasil e de seus habitantes para aqueles que eram apresentados aos textos historiográficos na condição de leitores. Possibilitava a esses mesmos leitores, além disso, dissociar as origens da História do Brasil daquelas de uma História Sagrada.

Ora, a exposição das funções da "Introdução" revela de modo mais contundente sua ambigüidade - ou, melhor dizendo, sua ambivalência -, expressada no tipo de numeração de 
suas páginas. De um lado, ela não deveria ser nada mais do que uma "introdução" aos "Capítulos". Isto porque a história que Abreu e Lima se dispunha a contar, por meio de um compêndio, era a história de uma nação - a Nação brasileira - que se constituíra como um novo corpo político - o Estado imperial, com a Independência em 1822. Uma nova Nação e um novo Estado - um Estado Nacional, ainda que este se apresentasse sob a forma de um império. Um Estado nacional que pressupunha um território delimitado, agora qualificado como um território nacional. Um território que, em sendo nacional, fundava a relação entre nascer e pertencer à nação. Mas um vasto território cuja particularidade era ter resultado de uma herança, uma preciosa herança, e cujos contornos já definidos urgia preservar, quer das ameaças externas quer das convulsões internas, ao mesmo tempo em que se vivia já a impossibilidade de uma expansão (MATTOS, 2005).

Contudo, um vasto território que, de modo anacrônico, o autor já apresentava como definido no momento do Descobrimento - “já os Portugueses tinham dado o primeiro passo para o Oriente quando o acaso lhes deparou o domínio de uma das mais vastas regiões do hemisfério Ocidental, o BRASIL" (grifo meu). Nestes termos, formar o Brasil fora o movimento de preenchimento (ou ocupação) de um vasto território por meio da ação colonizadora; e formar o Compêndio era contar por meio de sucessivos "capítulos" como foi preenchido um vasto e vazio território. "Capítulos" que pressupunham um preenchimento prévio - o de um tempo homogêneo e vazio -, realizado pela "Introdução"; mas "Capítulos" que com ela não se confundiam, por não ser ela ainda a "História do Brasil", mas apenas a sua "introdução", embora a qualidade que definia a expansão, mercantil e civilizatória, (posteriormente, tornar-se-ia mais comum falar em "sentido" ${ }^{\text {" } 47}$ ) viesse a definir também o destino da nação que surgia. Assim, em qualquer das dimensões consideradas - a dimensão temporal e a dimensão espacial -, sob a forma de uma "Introdução" ou de uma sucessão de "Capítulos", o ponto de partida de uma narrativa continha já o seu ponto de chegada. Mas dimensões que se apresentavam assimetricamente em uma relação: na narrativa dos “Capítulos", o eixo temporal e a qualidade que o distingue preenchem o território "brasileiro", prévia e anacronicamente dado; todavia, são os limites deste território - ou seja, a dimensão

\footnotetext{
${ }^{47}$ O exemplo mais conhecido é certamente o "sentido da colonização" que orienta a narrativa de Formação do Brasil contemporâneo de Caio Prado Junior, cuja primeira edição é de 1942. Mas Gilberto Freyre (1964) não deixa de se orientar por aquilo que denomina o "sentido semita da colonização".
} 
espacial - que estabelecem quais acontecimentos devem ser escolhidos para um preenchimento, isto é, narrados. ${ }^{48}$

Por outro lado, se a "Introdução" e os "Capítulos" não deviam se confundir (os tipos diferentes de algarismos servindo para marcar a diferença entre ambas as partes do "Texto principal"), a utilização de algarismos romanos para numerar as páginas da "Introdução" sugere algo mais do que uma diferenciação. Ora, à medida que, no decorrer do século XIX, a História se institucionalizava como uma nova disciplina, ia-se afirmando uma nova concepção de História, condição mesma para aquela institucionalização, a qual ficaria conhecida como a "concepção moderna de História". Desde então, aqueles que lidavam com o conhecimento histórico não mais lhe reservavam apenas a função de "mestra da vida", associada a uma “concepção antiga". A História deveria ser também "filosófica", constituindo-se, nas palavras de um estudioso, em um dos "terrenos privilegiados da demonstração do sentido da existência social” (FURET, s.d., p. 121). ${ }^{49}$ Da “concepção moderna de História” duas características destacam-se de imediato: o método crítico, em especial no trato da documentação que continha o registro das experiências vividas por outros homens e mulheres em outros tempos e lugares; e o seu caráter "filosófico", ou seja, a identificação do sentido geral da formação e evolução de um povo ou nação. Não por uma simples coincidência, ao encaminhar sua Memória ao concurso promovido pelo IHGB, von Martius apresentava-se como "um autor filosófico", conforme vimos acima. De sua parte, Abreu e Lima absorveria as novas reflexões a respeito de como escrever a História - mas sempre a seu modo! Ao pôr em evidência uma filiação, assim como o papel e o valor civilizatórios do comércio e das relações mercantis, nas páginas da "Introdução", ele afirmava seus compromissos com a nova concepção, embora não descartasse o conhecimento da História como uma "mestra da vida". De outra, as páginas do "Prefácio" (embora não apenas elas) revelavam como o método crítico era reduzido ao modo

\footnotetext{
${ }^{48}$ Aqui reside, certamente, a razão por que, embora tenha utilizado amplamente a História do Brasil de Robert Southey, publicada em 1810, Abreu e Lima tenha ignorado ou "deixado de fora" inúmeros outros acontecimentos ali narrados, motivando a crítica de alguns contemporâneos também a esse respeito. Para Abreu e Lima, os acontecimentos deixados "de fora" não pertenciam à História do Brasil por terem ocorrido "fora" do teritório "brasileiro", ainda no período colonial.

${ }^{49}$ A respeito das concepções antiga e moderna, cf. Koselleck (1993).
} 
de compilar ${ }^{50}$. Nestes termos, o "Prefácio" e a "Introdução" complementavam-se, formando um todo; e disto a numeração em romanos era uma evidência.

Os "Capítulos" contam a "História do Brasil - a narrativa da formação de uma nação, contida em um território. Uma narrativa que se inicia com o "Descobrimento do Brasil por Pedro Álvares Cabral” (I, 1), em 1500, e se estende até a coroação e sagração do segundo imperador, 341 anos depois:

Com a Coroação e Sagração do Senhor D. Pedro II termina uma época bem interessante na nossa história, e por isso concluo neste ato a minha narração, e até porque no momento em que escrevo, quatro meses depois, nenhum outro fato notável tem aparecido que mereça consignar-se, senão a guerra civil do Rio Grande, a que só Deus porá termo segundo vão as coisas no Império. Uma nova era começou em 18 de julho de 1841, assim como dez anos tinha marcado a Providência um decênio para o purgatório. Quais serão os futuros do Brasil? Se mau fado não nos persegue mais, como até aqui, podem anunciar-se como muito lisonjeiros debaixo do reinado do Segundo Pedro (II, 137-8).

Uma narrativa dividida em oito capítulos ou "épocas". Destas, as seis primeiras ocupam o primeiro tomo; e as duas últimas, abrangendo os períodos de 1821-1831 e 18311841, respectivamente, compõem o segundo tomo, em uma distribuição que pode ser explicada quer pelo interesse do autor em apresentar em um volume separado os acontecimentos desde a emancipação política; quer pelas preocupações dos editores em manter um equilíbrio de páginas entre os dois volumes, uma vez que às 138 páginas do texto referente aos dois últimos capítulos somavam-se as do "Índice cronológico da História do Brasil", as dos "Documentos em apenso" e as do "Índice das matérias contidas no segundo volume", perfazendo 369 páginas, enquanto o primeiro tomo possuía 344 páginas; quer ainda por uma convergência de interesses e preocupações de ambos - autor e editores. Capítulos ou “épocas" estabelecidos pelo próprio Abreu e Lima, conforme declarava em carta enviada ao IHGB apresentando o Compêndio, conforme já salientado. Dizia, então, que na

\footnotetext{
${ }^{50}$ Aqui talvez valha a pena retomar o juízo emitido por Capistrano de Abreu: "Abreu e Lima é um compilador".
} 
[...] divisão das épocas buscara sempre uma cor que as distinguisse, mas que essa cor devia ser tal que se apresentasse à primeira vista e que, para ser bem compreendida, era mister que cada época tivesse seu cunho particular, isto é, uma mudança, uma variação do estado anterior.

Muito ao seu feitio, propunha uma periodização própria, esquivando-se da proposição inicial do cônego Januário da Cunha Barbosa ao IHGB, a qual dividia a História do Brasil em uma "época antiga" e outra "moderna", e evitando as três "épocas" do Brigadeiro Cunha Matos. O quadro II abaixo apresenta os Capítulos e as Épocas respectivas fixados por Abreu e Lima, assim como o número de páginas dedicadas a cada um deles. Recordo ainda como, após narrar em Compêndio as oito épocas, o autor anunciava em seu trecho final uma nona, que teria tido início com a coroação e sagração do "Segundo Pedro".

\section{QUADRO II}

\begin{tabular}{|c|c|c|}
\hline Capítulos & Épocas & No. de Páginas \\
\hline Primeiro & $1500-1531$ & 42 \\
\hline Segundo & $1532-1580$ & 48 \\
\hline Terceiro & $1580-1640$ & 68 \\
\hline Quarto & $1641-1654$ & 42 \\
\hline Quinto & $1654-1807$ & 54 \\
\hline Sexto & $1808-1821$ & 64 \\
\hline Sétimo & $1821-1831$ & 78 \\
\hline Oitavo & $1831-1841$ & 60 \\
\hline
\end{tabular}

Não deixa de ser interessante que das 456 páginas dos "Capítulos" quase um terço delas seja dedicado às épocas de 1821-1831 e 1831-1841 (ou seja, a "época moderna" do cônego Januário ou a "terceira época" proposta por Cunha Matos), as quais abrangiam os acontecimentos desde a emancipação política. Caso a elas ajuntemos a sexta época - isto é, aquela referente à permanência da Família Real portuguesa no Brasil (1808-1821) -, o número de páginas chega a 203: vale dizer, em torno de $45 \%$ do total de páginas dos "Capítulos" eram dedicados a acontecimentos ocorridos em apenas 33 anos (em torno de 
9,5\% do total de anos abrangidos pela narrativa de Compêndio). Todavia, é importante que não se esqueça que muitos dos acontecimentos nelas apresentados tinham sido vividos intensamente pelo autor, de modo direto ou indireto; aos mesmos Abreu e Lima atribuiria sempre um valor essencial; contudo, não deixaria escapar a "cor" particular que distinguia cada uma daquelas três épocas, bastando lembrar que à época de 1831-1841 - o tempo das Regências -, dizia ele, "tinha marcado a Providência um decênio para o purgatório", conforme visto há pouco. Compendiar aquelas três épocas exigiu esforço e dedicação especiais! Por vezes, efetuara pequenas alterações em partes de textos referentes a acontecimentos "de que eu estava pessoalmente informado" (ABREU E LIMA, 1843a, p. x). como fora o caso do relato do padre Muniz Tavares sobre a Revolução de 1817, contrapondo assim a memória vivida ao relato escrito; por vezes, recorrera à própria experiência para redigir, por não ter o que compendiar, como foi o caso de todo o oitavo e último capítulo, "porque nada havia escrito desta época". Então, a cada linha parecia assumir aquilo que Jeanne Marie Gagnebin disse ser "uma tarefa paradoxal": não esquecer dos mortos e dos vencidos, não calar mais uma vez suas vozes, e, ao mesmo tempo, não cair na ilusão de que o trabalho intelectual encontra sua justificativa definitiva em um trabalho de acumulação, pois o apelo da vida no presente também exige que o pensamento saiba esquecer. Tarefa paradoxal e árdua na qual o autor e o ator se confundiam no ato de rememorar. ${ }^{51}$ Mas tarefa que, sob outra perspectiva, parecia ser não tanto a de redação de um compêndio, e sim a de uma espécie de testamento político, conforme destaca Ricardo Alberto Rivas ao analisar uma carta, em estilo marcademente autobiográfico, que o pernambucano endereçara a José Antonio Paez, em $1868 .^{52}$

Para formar os demais capítulos de Compêndio, as épocas anteriores a 1808, assim como alguns parágrafos dos capítulos VI e VII, Abreu e Lima não pode se servir, evidentemente, de uma experiência vivida. Mas deles não estará ausente, projetando muitas vezes fortemente as questões do presente no momento que narrava. Aqueles capítulos seriam o resultado de intensos estudos e leituras, atividades que procurara praticar sem interrupções,

\footnotetext{
51 “A palavra rememorativa, certamente imprescindível, não tira sua força mais viva da conservação do passado e da perseverança dos escritores, historiadores ou filósofos; mas do apelo à felicidade do presente, isto é, em termos filosóficos antigos, da exigência da vida justa dos homens junto a outros homens. Ouvir o apelo do passado significa também estar atento a esse apelo de felicidade e, portanto, de transformação do presente, mesmo quando ele parece estar sufocado e ressoar de maneira quase inaudível" (GAGNEBIN, 2006, p. 12).

52 "A literatura autobiográfica do século XIX mostra como refletia sobre si mesma a classe dirigente, constituindo em muitos casos uma espécie de testamento político”. (RIVAS, 2005).
} 
mesmo nos momentos mais adversos que enfrentara no decorrer de sua vida. Escolheu obras e autores que considerava mais adequados para serem compilados, assim como os que poderiam ser úteis quando fosse necessário fazer correções aos primeiros.

O Quadro III identifica as escolhas feitas por Abreu e Lima e o lugar que as mesmas ocupam na organização do texto de Compêndio. As obras e os autores identificados na abertura de cada um dos capítulos são os que foram compendiados; já os identificados com* são aqueles citados pelo autor em notas de pé-de-página, na parte mencionada.

\section{QUADRO III}

\begin{tabular}{|c|c|}
\hline COMPÊNDIO DA HISTÓRIA DO BRASIL & Autores e obras compendiados ou consultados \\
\hline CAPÍTULO PRIMEIRO 1500 - 1531 & $\begin{array}{l}\text { Aires de Casal.Corografia Brasílica. } \\
\text { F. A. de Varnhagen. Diário de Navegação de } \\
\text { Pero Lopes de Souza e Reflexões críticas sobre } \\
\text { o escrito no século XVI Notícias do Brasil.. } \\
\text { Robert Southey. História do Brasil.. } \\
\text { Henrique L. de Niemeyer Bellegard. Introdução } \\
\text { Corográfica à História do Brasil. }\end{array}$ \\
\hline $\begin{array}{l}\text { I. Descobrimento do Brasil por Pedro Álvares } \\
\text { Cabral }\end{array}$ & $\begin{array}{l}\text { * João de Barros. } \\
\text { * Aires de Casal, Corografia Brasílica. } \\
\text { * F. A. de Varnhagen. Reflexões críticas sobre } \\
\text { o espírito do século XVI. } \\
\end{array}$ \\
\hline II. Primeiras explorações das terras do Brasil & $\begin{array}{ll}\text { * F. A. de Varnhagen. Notas ao Diário de Pero } \\
\text { Lopes de Souza. } \\
\text { * História Geral das Viagens, t.14, livro } 6 . \\
\text { * Muller: História Universal, t. 2, cap. } 13 \text {. } \\
\text { * Carta do Visconde de Santarém in Bulletin de } \\
\text { la Société géografiqye de Paris, outubro de } \\
\text { 1835. } \\
\text { * Frei Gaspar da Madre de Deus. "Notícias dos } \\
\text { anos em que se descobriu o Brasil" in Revista } \\
\text { do IHGB, v. 2, p. } 425 \text {. }\end{array}$ \\
\hline $\begin{array}{l}\text { III. Martim Afonso de Souza navega por toda a } \\
\text { costa desde o Cabo de Santo Agostinho até o } \\
\text { Rio da Prata, e volta a fundar a Colônia de S. } \\
\text { Vicente. Duarte Coelho Pereira expulsa os } \\
\text { Franceses de Itamaracá }\end{array}$ & * Diário de Pero Lopes de Souza. \\
\hline IV. Descrição geral desta vasta região & $\begin{array}{l}* \text { Beauchamp. História do Brasil. } \\
\text { * Barão de Humboldt, Ensaio sobre N.E., t. 3, } \\
\text { livro 4, cap. } 11 \text {. } \\
\text { * Dr. J. Parigot, Memória sobre as minas de } \\
\text { carvão de pedra do Brasil. }\end{array}$ \\
\hline $\begin{array}{l}\text { V. Caracter, usos e costumes dos habitantes } \\
\text { naturais do Brasil }\end{array}$ & $\begin{array}{l}\text { * Diário de Pero Lopes de Souza. } \\
\text { * Revista da História do Brasil. }\end{array}$ \\
\hline
\end{tabular}




\begin{tabular}{|c|c|}
\hline CAPÍTULO SEGUNDO 1532 - 1580 & $\begin{array}{l}\text { Afonso de Beauchamp, História do Brasil } \\
\text {.recopilação da História do Brasil de R. Southey. } \\
\text { H. Bellegard, Resumo de História do Brasil } \\
\text { recopilação de Ferdinand Denis, Brésil. }\end{array}$ \\
\hline $\begin{array}{l}\text { I. Capitanias hereditárias estabelecidas no Brasil } \\
\text { no reinado d'El-Rei D. João III }\end{array}$ & $\begin{array}{l}\text { * Aires de Casal, Corografia Brasílica. } \\
* \text { Diário de Pero Lopes de Souza. Lisboa, } 1839 . \\
* \text { João de Barros. } \\
* \text { F. A. de Varnhagen. Reflexões críticas sobre } \\
\text { o espírito do século XVI, p. } 85 . \\
\end{array}$ \\
\hline \multicolumn{2}{|l|}{$\begin{array}{l}\text { II. Estado das outras Capitanias. Chegada ao } \\
\text { Brasil de Tomé de Souza, primeiro Governador } \\
\text { Geral }\end{array}$} \\
\hline \multicolumn{2}{|l|}{$\begin{array}{l}\text { III. Influência da Religião no Brasil. Estado do } \\
\text { Clero da Colônia. Segundo e terceiro } \\
\text { Governadores Geraes }\end{array}$} \\
\hline $\begin{array}{l}\text { IV. Tentativa dos Franceses para se } \\
\text { estabelecerem no Brasil. Expedição de Nicolau } \\
\text { Durand de Villegaignon. Expulsão dos } \\
\text { Franceses do Rio de Janeiro. Fundação da } \\
\text { Cidade de S. Sebastião }\end{array}$ & $\begin{array}{l}\text { * Pizarro. } \\
\text { * Rocha Pita. } \\
* \text { Sebastião de Vasconcelos. }\end{array}$ \\
\hline \multicolumn{2}{|l|}{$\begin{array}{l}\text { V. Divisão do Brasil em dois Governos distintos. } \\
\text { Transmigração dos Tupinambás. O Brasil de } \\
\text { novo debaixo de um só Governo. } \\
\text { Acontecimentos que fazem passar o Reino de } \\
\text { Portugal e suas Colônias para o domínio da } \\
\text { Espanha }\end{array}$} \\
\hline CAPITULO TERCEIRO 1580 - 1640 & $\begin{array}{l}\text { Afonso de Beauchamp. História do Brasil } \\
\text { recopilação de História do Brasil de R. Southey. } \\
\text { H. Bellegard, Resumo de História do Brasil } \\
\text { recopilação de Ferdinand Denis, Brésil. }\end{array}$ \\
\hline $\begin{array}{l}\text { I. Estado do Brasil na época em que passou para o } \\
\text { domínio da Espanha. Diversas incursões dos } \\
\text { piratas ingleses. Novas indagações sobre as } \\
\text { minas de prata do Brasil. O fabuloso pais - El } \\
\text { Dorado. }\end{array}$ & $\begin{array}{l}\text { * F.A.Varnhagen. Reflexões críticas sobre o } \\
\text { escrito do século XVI. }\end{array}$ \\
\hline $\begin{array}{l}\text { II. Administração de Pedro Botelho. Aliança dos } \\
\text { Aimorés. D. Diogo de Menezes. Fundação do } \\
\text { Ceará. Estabelecimento dos Franceses no } \\
\text { Maranhão. Gaspar de Souza. }\end{array}$ & $\begin{array}{l}\text { * Rocha Pita. História do Brasil. Liv. III, num, } \\
101 .\end{array}$ \\
\hline \multicolumn{2}{|l|}{$\begin{array}{l}\text { III. Expedição de Jerônimo de Albuquerque e de } \\
\text { Alexandre de Moura. Expulsão dos Franceses } \\
\text { da ilha e costa do Maranhão. Conquista do } \\
\text { Grão-Pará, e fundação da Cidade de Belém. } \\
\text { Criação do novo Estado do Maranhão. }\end{array}$} \\
\hline $\begin{array}{l}\text { IV. Os Holandeses invadem o Brasil. Occupação } \\
\text { da Cidade de S. Salvador. Expulsão dos } \\
\text { Holandeses. Incursões parciais. Crueldade } \\
\text { cometida contra os Índios. }\end{array}$ & * Rocha Pita. História do Brasil. \\
\hline
\end{tabular}




\begin{tabular}{|c|c|}
\hline $\begin{array}{l}\text { V. Segunda expedição holandesa contra o Brasil. } \\
\text { Ocupação de Olinda e do Recife. Campo Real } \\
\text { do Bom Jesus. Surpresa do Gereral Loncq. } \\
\text { Ataque de Olinda pelos Portugueses. }\end{array}$ & $\begin{array}{ll}* & \text { Brito Freire. } \\
* & \text { Frei Rafael de Jesus ( Castrioto). } \\
* & \text { Rocha Pita. } \\
* & \text { D. Francisco Manoel de Mello. (Epanáforas } \\
\text { V). } \\
\end{array}$ \\
\hline $\begin{array}{l}\text { VI. A guerra muda de aspecto. Combate naval. } \\
\text { Incêndio de Olinda. Calabar abandona os } \\
\text { Portugueses. Consequiências funestas da sua } \\
\text { traição. Morte do General holandes Reimbach. } \\
\text { Rasgo patriótico de Jaguarary. Os Palmares. } \\
\text { Conquista da Paraíba pelos holandeses. } \\
\text { Ocupação do Pontal de Nazareth. }\end{array}$ & $\begin{array}{l}\text { * Desembargador Silva Pontes, Revista do } \\
\text { IHGB, v. 3, p. 152-153. }\end{array}$ \\
\hline $\begin{array}{l}\text { VII. Últimos esforços dos Portugueses em } \\
\text { Pernambuco. Emigração e abandono da } \\
\text { Província. Ocupação de Porto calvo. Suplício } \\
\text { de Calabar. Albuquerque é chamado à Europa. } \\
\text { Rebello, Camarão e Henrique Dias. Segunda } \\
\text { emigração de Pernambuco. Maurício de } \\
\text { Nassau. Derrota dos Portugueses em Porto } \\
\text { Calvo. Fuga de Bagnuolo. Segunda invasão da } \\
\text { Bahia. Retirada de Nassau. Outras conquistas } \\
\text { dos Holandeses. }\end{array}$ & \\
\hline $\begin{array}{l}\text { VIII. Estado político das Províncias do Maranhão. } \\
\text { Viagem de Teixeira pelo Amazonas até Quito. } \\
\text { Sua volta a Belém. O Conde da Torre. O } \\
\text { Marquês de Montalvão, primeiro Vice-Rei } \\
\text { nomeado para o Brasil. Revolução de Portugal. }\end{array}$ & * Teatro Heroíno, t.1, p. 232. \\
\hline CAPITULO QUARTO 1641 - 1654 & $\begin{array}{l}\text { Afonso de Beauchamp, História do Brasil } \\
\text { recopilação de História do Brasil de R. Southey. } \\
\text { H. Bellegard, Resumo de História do Brasil } \\
\text { recopilação de Ferdinand Denis, Brésil. }\end{array}$ \\
\hline $\begin{array}{l}\text { I. O Brasil entra de novo no domínio português. } \\
\text { Mauricio de Nassau deixa o governo da } \\
\text { Colônia, e volta para a Holanda. Decadência } \\
\text { do Brasil holandes. O Maranhão e o Ceará } \\
\text { libertam-se dos Holandeses. Conspiração de } \\
\text { Pernambuco descoberta. João Fernandes Vieira } \\
\text { reúne os seus amigos e toma as armas. }\end{array}$ & $\begin{array}{l}\text { * Biografia de Salvador Correa de Sá e } \\
\text { Benevides in Revista do IHGB, t. 3, p. } 100 .\end{array}$ \\
\hline $\begin{array}{l}\text { II. Vieira é reconhecido Chefe dos Independentes } \\
\text { de Pernambuco. Combate de Tabocas. Junção } \\
\text { de Vidal, Moreno, Henrique Dias, e Camarão } \\
\text { com João Fernandes Vieira. Combate naval de } \\
\text { Tamandaré. Ataque e tomada da casa Forte por } \\
\text { Vieira e Vidal. O General Huss prisioneiro. }\end{array}$ & \\
\hline $\begin{array}{l}\text { III. Compra da Fortaleza de Nazaré. Ataque de } \\
\text { Itamaracá. Traição dos trânsfugas holandeses, } \\
\text { Vieira queima as suas próprias plantações. } \\
\text { Conspiração contra Vieira. Sua } \\
\text { magnanimidade. O General Sigismundo chega } \\
\text { com uma frota holandesa ao Recife. }\end{array}$ & \\
\hline
\end{tabular}




\begin{tabular}{|c|c|}
\hline $\begin{array}{l}\text { IV. Proposição de anistia. Resposta de Vieira. } \\
\text { Sigismundo é batido e ferido. Tomada da ilha } \\
\text { de Itaparica. Morte de Rebello. O Conde de } \\
\text { Villapouca vem render a Teles da Silva. } \\
\text { Francisco Barreto de Menezes toma o mando } \\
\text { do exército de Pernambuco. Batalha dos } \\
\text { Guararapes. Triunfo dos Pernambucanos. }\end{array}$ & * Rocha Pita. \\
\hline $\begin{array}{l}\text { V. Apoderam-se os Holandeses de Olinda. } \\
\text { Sortida do General Brinck. Sigismund devasta } \\
\text { de novo as costas da Bahia. Morte de Camarão. } \\
\text { Segunda batalha dos Guararapes. Derrota e } \\
\text { morte do General Brinck. O Conde de Castelo } \\
\text { - melhor Vice-rei do Brasil. Continuação do } \\
\text { cerco do Recife. }\end{array}$ & \\
\hline $\begin{array}{l}\text { VI. A esquadra de Magalhães surge em Nazaré. } \\
\text { Conselho de guerra. Bloqueio do Recife. } \\
\text { Ataque das obras exteriores por Vieira. Ataque } \\
\text { das Cinco-Pontas. Motim do povo e da } \\
\text { guarnição do Recife. Capitulação dos } \\
\text { Holandeses. Todo o Brasil entra no domínio da } \\
\text { Coroa de Portugal. }\end{array}$ & $\begin{array}{l}\text { * D. Francisco Manoel de Mello. Epanáforas V. } \\
\text { * Anais do Rio de Janeiro, t. 6, Revista do } \\
\text { IHGB, t.2. }\end{array}$ \\
\hline CAPITULO QUINTO 1654 - 1807 & $\begin{array}{l}\text { Afonso de Beauchamp. História do Brasil } \\
\text { recopilação de História do Brasil de R. Southey. } \\
\text { H. Bellegard. Resumo de História do Brasil } \\
\text { recopilação de Ferdinand Denis, Brésil. }\end{array}$ \\
\hline $\begin{array}{l}\text { I. Tratado de paz de } 1660 \text { entre Portugal e a } \\
\text { Holanda. O Príncipe D. Pedro, Regente de } \\
\text { Portugal. Tratado de paz de } 1668 \text { entre } \\
\text { Portugal e a Espanha. Estado do Brasil. Os } \\
\text { Paulistas ou Mamelucos do Brasil durante o } \\
\text { século XVII. }\end{array}$ & $\begin{array}{l}* \text { Catástofre de Portugal. } \\
* \text { Rocha Pita. }\end{array}$ \\
\hline $\begin{array}{l}\text { II. A Ilha de Santa Catarina. Povoação das } \\
\text { Alagoas. Fundação da Colônia do Sacramento. } \\
\text { Sabará e Villa Rica. Guerra civil. Antonio } \\
\text { d'Albuquerque, Governador do Distrito das } \\
\text { Minas. Destruição completa dos Palmares }\end{array}$ & \\
\hline $\begin{array}{l}\text { III. Bispados do Brasil. Expedição malograda de } \\
\text { Duclerc. Duguay-Trouin toma a cidade do Rio } \\
\text { de Janeiro, que foi depois resgatada pelos seus } \\
\text { habitantes. }\end{array}$ & $\begin{array}{l}\text { * Paricipação da Câmara da cidade do Rio de } \\
\text { Janeiroa D. João V extraída do registro da } \\
\text { mesma câmara a fl. } 179 \text { in Jornal de Belas } \\
\text { Artes ou Mnemosine Lusitana, no. } 13 \text { ou in } \\
\text { Memória do Bispo D. José Joaquim da Cunha } \\
\text { da Azeredo Coutinho apresentada na } \\
\text { Academia Real de Ciência de Lisboa, in A. de } \\
\text { Beauchamp. }\end{array}$ \\
\hline $\begin{array}{l}\text { IV. Tratado de Utrecht. A Cidade de Mariana. } \\
\text { Vila do Cuiabá. Vila Boa de Goiás. Primeiro } \\
\text { diamante achado no Brasil. Tratado de 1750. O } \\
\text { Marquês de Pombal. Extinção dos Jesuítas. }\end{array}$ & $\begin{array}{l}\text { * Dedução cronológica e analítica e Relação } \\
\text { abreviada da República dos Jesuítas in } \\
\text { Dedução cronológica. } \\
\text { * Anais do Rio de Janeiro, t. } 6 .\end{array}$ \\
\hline
\end{tabular}




\begin{tabular}{|c|c|}
\hline $\begin{array}{l}\text { V. Influência da administração de Pombal sobre o } \\
\text { Brasil. Guerras do Sul. Santa Catarina e a } \\
\text { Colônia do Sacramento caem em poder dos } \\
\text { Espanhóis. Dona Maria I. Queda do Marquês } \\
\text { de Pombal. Tratados de } 1777 \text { e } 1778 \text {. o Arraial } \\
\text { do Tejuco. Grande diamante da Coroa de } \\
\text { Portugal. }\end{array}$ & * Revista do Instituto Histórico, t. 2. \\
\hline $\begin{array}{l}\text { VI. Projeto de revolução em Minas. O Príncipe D. } \\
\text { João Regente de Portugal. Estado do Brasil no } \\
\text { fim do século XVIII. Guerra de } 1801 . \\
\text { Transmigração da Família Real de Bragança } \\
\text { para o Brasil. }\end{array}$ & $\begin{array}{l}\text { * Revista do Instituto Histórico, t. 3, p. } 209 . \\
\text { * Anais da província de S. Pedro pelo } \\
\text { visconde de S. Leopoldo, cap. XI. }\end{array}$ \\
\hline CAPITULO SEXTO 1808 - 1821 & $\begin{array}{l}\text { Armitage "com alterações a partir de outros } \\
\text { escritos". } \\
\text { Visconde de S. Leopoldo. Anais sobre o Rio } \\
\text { Grande do Sul e Montevidéu. } \\
\text { Muniz Tavares sobre a revolução de } 1817 .\end{array}$ \\
\hline $\begin{array}{l}\text { I. A Família Real chega ao Brasil. Entusiasmo } \\
\text { geral. Os portos do Brasil abrem-se a todas as } \\
\text { nações amigas. Novos e importantes } \\
\text { estabelecimentos. Tomada e ocupação de } \\
\text { Caiena. D. Rodrigo de Souza Coutinho. Os } \\
\text { aventureiros que acompanharam a Família } \\
\text { Real. O Brasil elevado à categoria de Reino. }\end{array}$ & \\
\hline $\begin{array}{l}\text { II. Revolução e Independência de Buenos Ayres. } \\
\text { Exército de observação nas fronteiras do Rio } \\
\text { Grande. Campanhas de } 1811 \text { e } 1812 . \\
\text { Armistício. A divisão portuguesa de } \\
\text { voluntários d' El-Rei. Campanhas de } 1816 \text { e } \\
\text { 1817. Occupação de Montevidéo e da Colônia } \\
\text { do Sacramento. }\end{array}$ & $\begin{array}{l}\text { * Correio Brasiliense. setembro de } 1820, p \text {. } \\
228 \text {. }\end{array}$ \\
\hline $\begin{array}{l}\text { III. Morte da rainha. Revolução de Pernambuco. } \\
\text { Causas principais deste acontecimento. } \\
\text { Conselho de guerra. Morte do Brigadeiro } \\
\text { Manoel Joaquim Barbosa de Castro. O } \\
\text { Governador capitula no Forte do Brum, e parte } \\
\text { para o Rio de Janeiro. Governo provisório. }\end{array}$ & $\begin{array}{l}\text { * Correio Brasiliense. setembro de } 1820 \text {, t. } 25, \\
\text { p. } 10 \text { a } 138 .\end{array}$ \\
\hline $\begin{array}{l}\text { IV. A Paraíba e o Rio Grande do Norte. } \\
\text { Comissões ao Ceará e à Bahia. Funestos } \\
\text { resultados. Bloqueio de Pernambuco. O } \\
\text { Marechal Gogominho e as tropas da Bahia. } \\
\text { Reação nas Alagoas, no Rio Grande e na } \\
\text { Paraíba. Combate de Ipojuca. Dissolve-se o } \\
\text { Governo Republicano. Os patriotas são } \\
\text { remetidos para a Bahia. Novas execuções } \\
\text { naquela Cidade. Luiz do Rego chega a } \\
\text { Pernambuco. Outros suplícios. A Alçada. }\end{array}$ & \\
\hline $\begin{array}{l}\text { V. Prosseguem as hostilidades no Sul. Vários } \\
\text { combates. Convenção de } 1819 \text {. Artigas retido } \\
\text { no Paraguai. Definitiva incorporação de } \\
\text { Montevidéu ao Reino Unido de Portugal, } \\
\text { Brasil, e Algarves. }\end{array}$ & \\
\hline
\end{tabular}




\begin{tabular}{|c|c|}
\hline $\begin{array}{l}\text { VI. Revolução de Portugal em 1820. Seus efeitos } \\
\text { no Brasil. O Pará e a Bahia pronunciam-se pela } \\
\text { futura Constituição Portuguesa. Soltura dos } \\
\text { presos de Pernambuco. Conduta de Luiz do } \\
\text { Rego. Acontecimentos do Rio de Janeiro. A } \\
\text { tropa e o Príncipe Real. Reunião eleitoral. Os } \\
\text { tiros da Praça do Comércio. El-Rei embarca } \\
\text { para Portugal. D. Pedro Regente do Brasil. }\end{array}$ & \\
\hline CAPITULO SÉTIMO 1821 - 1831 & $\begin{array}{l}\text { Armitage "com alterações a partir de outros } \\
\text { escritos". Visconde de S. Leopoldo, Anais sobre o } \\
\text { Rio Grande do Sul e Montevidéu. } \\
\text { Muniz Tavares sobre a revolução de } 1817 .\end{array}$ \\
\hline $\begin{array}{l}\text { I. Primeiros atos do Príncipe Regente. Influência } \\
\text { das tropas portuguesas. Efeito das medidas } \\
\text { legislativas tomadas pelas Cortes de Lisboa } \\
\text { acerca do Brasil. S. Paulo e o Rio de Janeiro se } \\
\text { pronunciam contra a partida do Príncipe. } \\
\text { Embarque da Divisão Lusitana. Convocação de } \\
\text { um Conselho de Procuradores das Províncias. } \\
\text { Novas desordens em Pernambuco e na Bahia. }\end{array}$ & $\begin{array}{l}\text { * Armitage "com alterações a partir de outros } \\
\text { escritos". Visconde de S. Leopoldo, Anais } \\
\text { sobre o Rio Grande do Sul e Montevidéu.. } \\
\text { * Muniz Tavares sobre a revolução de } 1817 \text {. }\end{array}$ \\
\hline $\begin{array}{l}\text { II.Uma Esquadra portuguesa chega ao Rio de } \\
\text { Janeiro. Sua volta. Viagem do Príncipe Real a } \\
\text { Minas. O título de Defensor Perpétuo. } \\
\text { Convocação da Assembléia Constituinte. } \\
\text { Manifestos. Viagem a S. Paulo. O grito do } \\
\text { Ipiranga. O Príncipe é aclamado Imperador do } \\
\text { Brasil. Coroação. }\end{array}$ & \\
\hline $\begin{array}{l}\text { III. Sete Deputados Brasileiros abandonam as } \\
\text { Cortes de Lisboa. Lord Cockrane entra no } \\
\text { serviço do Brasil. Os Portugueses evacuam a } \\
\text { Bahia. Cochrane segue a Esquadra Portuguesa } \\
\text { alguns dias e volta sobre o Maranhão. Sucessos } \\
\text { do Maranhão e do Pará. Horrível catástrofe. A } \\
\text { Divisão Lusitana capitula e evacua } \\
\text { Montevidéu. A Assembléia Constituinte do } \\
\text { Brasil. Demissão do Ministério dos Andradas. } \\
\text { Dissolução da Constituinte. Deportação de seis } \\
\text { Deputados. }\end{array}$ & \\
\hline $\begin{array}{l}\text { IV. Manifesto relativo à dissolução da } \\
\text { Constituinte. Mediação da Inglaterra. Primeiras } \\
\text { negociações acerca do reconhecimento da } \\
\text { Independência por Portugal. Revolução de } \\
\text { Pernambuco. Acontecimentos subsequientes. } \\
\text { Pacificação completa do Norte. Execuções. } \\
\text { Lord Cochrane torna ao Maranhão. } \\
\text { Contribuição forçada. Sua volta para } \\
\text { Inglaterra. Motim militar na Bahia. Assassinato } \\
\text { do Governador das Armas. }\end{array}$ & \\
\hline
\end{tabular}




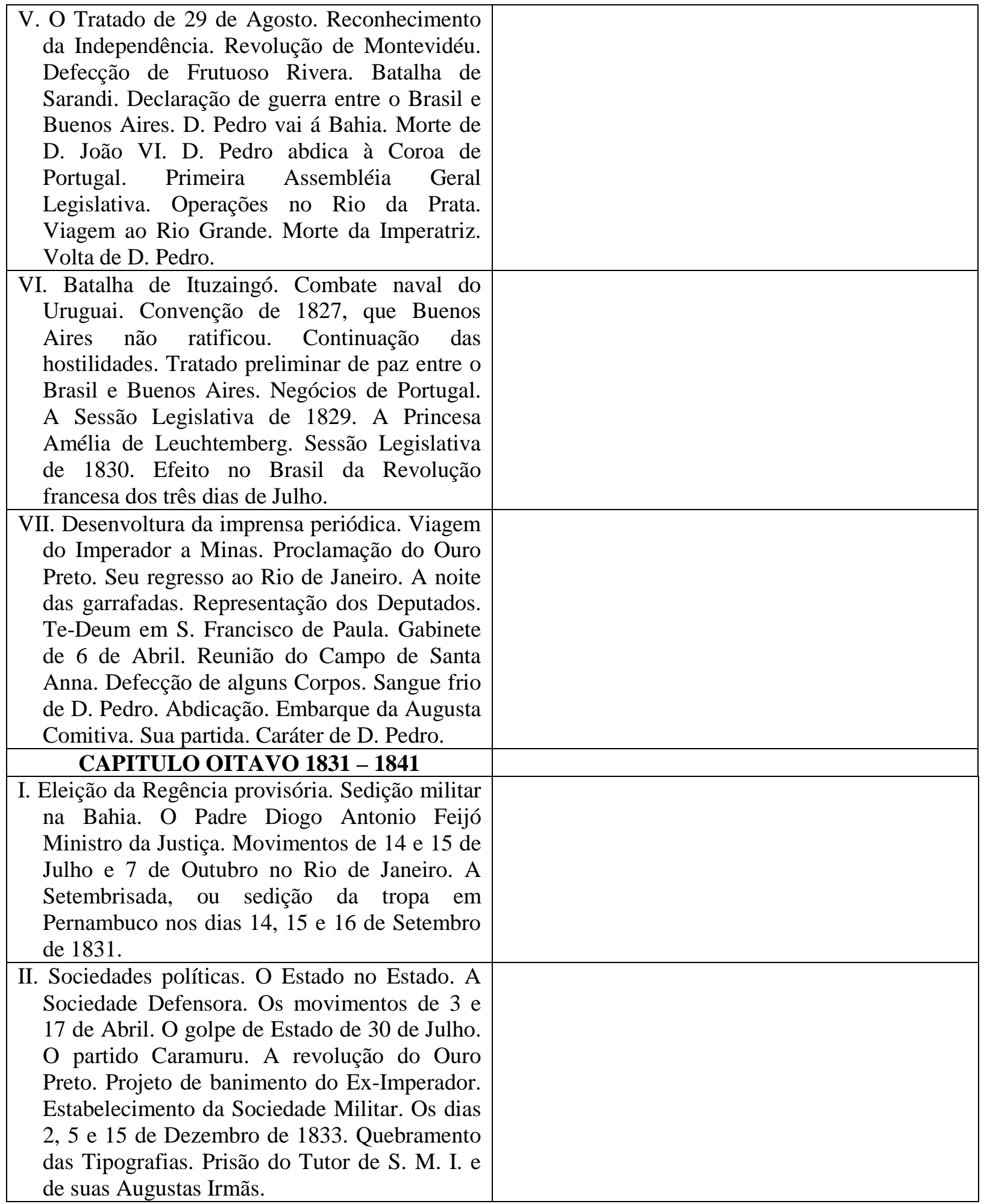




\begin{tabular}{|l|l|}
\hline III. Movimento de 14 de Abril em Pernambuco. \\
Guerra dos Cabanos. Revolução do Ceará. \\
Assassinato jurídico de Pinto Madeira. \\
Movimentos de 13 de Setembro e 19 de \\
Novembro de 1831 no Maranhão. Guerra civil \\
no interior. Morte do Caudilho rebelde. \\
Pacificação da Província. O Pará desde 1831 \\
até a presente época. \\
\hline IV. O banimento do Ex-Imperador. O Ato \\
adicional. Eleição do Padre Feijó para Regente \\
do Império. Revolução do Rio Grande do Sul. \\
Araújo Ribeiro e Bento Manoel. Combate do \\
Fanfa. Prisão de Bento Gonçalves. Demissão \\
de Araújo Ribeiro. O Brigadeiro Antero \\
Presidente. Sua prisão. Feijó resigna o cargo de \\
Regente. Pedro de Araújo Lima Regente \\
interino. Revolução da Bahia. \\
\hline V. A Bahia entra na ordem legal. Desastre do Rio \\
Pardo. Fuga de Bento Gonçalves. Assassino do \\
Presidente do Rio Grande do Norte. Sedição de \\
Raymundo Gomes. Retirada do Cá. Tomada \\
da Laguna. Combate do Taquari. Luiz Alves de \\
Lima Presidente do Maranhão. \\
\hline VI. Emenda ao voto de graças. Projeto da \\
Maioridade no Senado. Projeto de reforma do \\
artigo 121 da Constituição. Adiamento da \\
Assembléia Geral. A reunião no Senado. O \\
Quero já do Imperador. Sua Majestade presta o \\
juramento constitucional. Ministério de 24 de \\
Julho. Anistia de 22 de Agosto. Sagração e \\
Coroação do Senhor D. Pedro II. Futuros do \\
Brasil.
\end{tabular}

Como é possível constatar, o autor utilizou na maior parte das vezes obras e autores havia muito conhecidos, assim como se serviu de memórias, notícias e artigos de autoria de historiadores contemporâneos, publicados em jornais, como o Jornal do Comércio, e em revistas, como a Revista do IHGB. Não obstante, opiniões contrárias logo se manifestariam, a respeito das escolhas e dos métodos utilizados.

Do trabalho realizado resultaria um texto ágil, mesmo quando o autor não fez senão resumir autores e estilos diversos. As notas de pé-de-página acentuavam as qualidades positivas do texto, procurando conferir-lhe quer uma marca de erudição quer de intimidade com o que poderíamos chamar de produção historiográfica à época. Mas também um texto não isento de equívocos, imprecisões e incoerências, e que se oferecia aberto à crítica de ser 
permeado pelos preconceitos e juízos de valor de seu autor, os quais foram acentuados com a retirada da maior parte das notas e de todos os documentos a partir da $2^{\mathrm{a}}$ edição.

Embora tenha compendiado autores, textos e documentos diversos Abreu e Lima seguiu, em grande parte, a edição portuguesa da História do Brasil de Beauchamp, traduzida por Desidério Marques Leão. A apropriação que dela fez ajuda a compreender melhor a organização do texto principal e das notas, assim como possibilita refinar a compreensão que Abreu e Lima tinha de um compêndio.

Ao folhear a edição portuguesa publicada em Lisboa, em 1817, o leitor encontra uma advertência do editor - "Vertida do francês, e acrescentada de muitas notas do tradutor". Logo a seguir, um Prólogo, assinado pelo próprio tradutor, e que tem por objetivo informar a respeito das dificuldades e perigos do trabalho historiográfico:

Quem não conhece a grandíssima dificuldade em escrever a História? Quem ignora as leis rigorosas de absoluta observância, e em tamanho número, que está obrigado a guardar, ainda sem atender aos dotes que é preciso ter, o que se determina desempenhar este gênero de aumento?

E, indo direto ao ponto que deseja sublinhar, Desidério tornava pública sua avaliação sobre o autor e a obra em questão.

Do autor da presente História, é certo que não podemos dizer outro tanto; pois ele confessa haver consultado e de boa fé, muitas obras, e faz em seu prefácio extensa lista das que lhe serviram de fontes, a quem seguiu, consultou e refutou; mas no citar dos mesmos autores tem muita confusão, como se pode ali ver, e eu de propósito não quis mudar pondo tudo, e do mesmo modo que ele o traz; teve falta de alguns, donde poderia extrair luz para muitas coisas; e cercado pela multidão dos mesmos fatos que encontrou, e distraído pela diversidade, e distância dos lugares, e sem o devido conhecimento das pessoas que neles figuravam, circunstâncias com as quais os mesmos fatos não podem adquirir a clareza precisa para a sua inteligência; no decurso da sua História qualquer um poderá notar perplexo 
algumas vezes, por assim dizer, no expor dos fatos, e referi-los sem individuação, e com ambigüidade.

Nesta maneira nada acrescentei, ou mudei no texto, procurando com fidelidade restringir-me unicamente à obrigação de Tradutor, dando as coisas tais quais foram por ele escritas ou extensa, ou abreviadamente, para que o leitor imparcial faça o devido conceito dele, e da Obra. Julguei contudo próprio do meu dever, por evitar o inconveniente, que a mim mesmo me embaraçava, corrigir os descuidos históricos; tomei a liberdade, por não ficarem enganados os menos lidos, e práticos nesta História, de os apontar nas notas, e será assim de menos confusão, encontrando-se cada um em seu próprio lugar e com bastante clareza. Não pretendi nelas fazer ostentação, ampliando os fatos, ou dando-lhes diversa perspectiva para interessar mais a narração, ou torná-la mais agradável, ou interessante: unicamente procurei dar a verdade naquelas coisas que o autor escreveu com menos acerto, para crédito da mesma História, e fi-lo apontando de propósito os mesmos livros, e dos mesmos escritores, de que ele se serviu.

Insatisfeito com o texto original de Beauchamp, o tradutor introduzira, por conta própria, notas de pé-de-página ao texto original, com o objetivo de suprir ausências ou corrigir equívocos.

Assim, o "Texto principal" do Compêndio de Abreu e Lima resultava, em larga medida, de uma obra que não deixava de ser uma espécie de compêndio, a qual encontrara um revisor e atualizador no seu tradutor para a edição portuguesa. Ora, esta constatação apresentava-se para mim como um ponto de partida, impondo-me uma análise comparativa entre o Compêndio e a edição portuguesa da História do Brasil de Beauchamp.

De imediato, observo que Abreu e Lima - e Varnhagen não deixaria de anotar isto com rigor! - segue muito de perto não só o texto de Beauchamp, como também se utiliza das informações contidas nas notas do tradutor. 
Os capítulos de II a V de Compêndio, incluídas as notas de pé-de-página, são uma transcrição literal em inúmeras passagens; em outros trechos, o resumo; por vezes, um recorte da edição portuguesa de Beauchamp, acrescidos de períodos escritos de próprio punho. Em qualquer dos sentidos que se tome, o autor pernambucano compendiou.

Além disso, a leitura das notas dos referidos capítulos demonstra que, assim como Desidério havia tido o cuidado, no seu entender, de "corrigir os descuidos históricos" de Beauchamp, Abreu e Lima transformaria passagens e informações contidas no texto principal da edição portuguesa em notas de pé-de-página do Compêndio. Desde então, as notas dos "Capítulos" ganhavam um valor incomum, rivalizando por vezes com o próprio texto ${ }^{53}$ do capítulo.

Mas o procedimento utilizado para as notas de pé-de-página dos capítulos de II a V não se limitava aos mesmos. À medida que a análise prosseguia pude verificar que as notas elaboradas por Abreu e Lima para o Compêndio apresentavam uma acentuada variedade no que se refere à composição. Assim sendo, tomei a decisão de organizá-las, classificando-as segundo o atributo "composição". Seguem abaixo, exemplificados, os nove tipos de notas identificados: 54

1- Notas cujo texto foi integralmente copiado do texto de Beauchamp, como, por exemplo, a nota do capítulo II, página 66 que corresponde ao texto da edição portuguesa de Beauchamp situado no Tomo I, páginas 248-249: ${ }^{55}$

Durante o Governo de Tomé de Souza, os Portugueses do Brasil fizeram as primeiras diligências para a descoberta das minas de ouro e de diamantes no interior das capitanias de Porto Seguro e do Espírito Santo; mas os aventureiros que se arriscaram sem algum indício certo a pesquisas

\footnotetext{
${ }^{53}$ O leitor já deve ter reparado que denomino de "Texto principal" a "Introdução" e os "Capítulos", formados por um texto e as notas respectivas. A partir de agora, a denominação texto (com "t" minúsculo) remete exclusivamente ao texto do capítulo ou da introdução, de modo a dissociá-lo das notas.

${ }^{54}$ Devo a Leandro Janke, aluno de Graduação do Curso de História da PUC-RJ e bolsista PIBIC-CNPq, a acuidade com que me ajudou a realizar a análise comparativa e a classificação das notas.

${ }^{55}$ Daqui em diante a indicação das páginas de Compêndio conterá o número do capítulo seguido do número da página: II, 66, enquanto que a da obra de Beauchamp remete ao tomo e página respectivos: I, 248/249.
} 
perigosas, encontraram tão grandes dificuldades que voltaram a seus estabelecimentos sem alcançar resultado algum, nem ainda esperanças.

2- Notas cujo texto foi copiado integralmente por Abreu Lima das notas do tradutor da edição portuguesa como, por exemplo, na nota III, 115 que corresponde à nota do tradutor III, 37:

Os baianos no primeiro assalto defenderam-se com valor, tanto que rechaçaram os inimigos; mas o pânico terror pela dificuldade de socorros, que não podiam esperar, foi ocasião de desampararem a cidade para salvarem as vidas. Todavia, o que deixaram de obrar na defesa desempenharam depois no ataque, impedindo todo o progresso das armas dos Holandeses, como diz Rocha Pita fazendo a descrição daquela campanha.

3- Notas cujo texto foi copiado parcialmente do texto de Beauchamp, como, por exemplo, a nota V, 216 que contém passagens encontradas em VI, 82-88:

Albuquerque veio revestido de poder civil e militar, debaixo do título de Governador do Distrito das Minas. Chegando ao Rio de Janeiro com um regimento às suas ordens, recebeu aqui mais tropa, e foi a S. Paulo, e dali a Ouro Preto, onde desenvolveu toda a sua energia para impor respeito aos partidos; o que conseguiu de toda à força de constância e de muita prudência. Em 1711, mudou ele a povoação do Ouro Preto para o local onde hoje se acha a cidade do mesmo nome; porém com a mudança do sítio mudou-lhe também o nome, dando-lhe o de Vila Rica. Foi aqui que ele lançou os fundamentos de uma Cidade regular com um palácio do Governo, um erário e uma casa de fundição. Segundo os seus poderes e instruções, deu um código de leis relativas às minas, e aos mineiros, em virtude do qual eram estes obrigados a entregar aos oficiais d' El-Rei todo o ouro, que pudessem colher nos seus terrenos, para ser reduzido à barras, marcadas e seladas conforme o seu titulo e valor, e depois entregue aos proprietários 
com um certificado, que autorizava para poderem correr. Permitiu-se também, para facilitar as transações do comércio, a circulação do ouro em pó para os pequenos trocos e pagamentos. Tornada o centro de grandes riquezas, abriu Vila Rica o seu comércio com o Rio de Janeiro, ainda que sempre sujeita a S. Paulo; até que em 1720 se desmembrou, formando com o imenso território, que lhe fora adjudicado, a importante província de Minas Gerais, cujo primeiro Governador e Capitão General foi D. Lourenço de Almeida.

4- Notas cujo texto reproduz parte da nota redigida pelo tradutor de Beauchamp, como, por exemplo, a nota III, 110 que corresponde a um fragmento da nota do tradutor em II, 317:

"Diogo Mendonça Furtado tomou conta do governo em 1622; era o primeiro Governador e Capitão General nomeado por Felipe IV para o Estado do Brasil.”.

5- Notas cujo texto é uma mescla do texto de Beauchamp e das notas do tradutor da edição portuguesa, como, por exemplo, a nota III, 123 que é em parte cópia do texto do Beauchamp (III, 122/23) e em parte cópia da nota do tradutor (trecho que apresento sublinhado):

João Fernandes Vieira, filho do Funchal na ilha da Madeira, tinha-se embarcado de idade de onze anos para vir procurar fortuna em Pernambuco, não tendo então outros bens senão as suas disposições felizes, e o germe de alguns talentos. Este feito de armas, o primeiro em que o moço Vieira entrou, foi o precursor da grande empreza, na qual alcançou o título honorifico de Restaurador de Pernambuco. Capitulando o Capitão Antonio de Lima, quando o Forte não era mais do que um montão de ruínas, Vieira cingiu-se com a bandeira, e saiu com ela, occultando-a debaixo dos vestidos para que não caisse em poder dos vencedores. Sua vida especial pode ler-se 
no que dele escreveu Fr. Rafael de Jesus, além de Brito Freire, Rocha Pita, D. Francisco Manoel de Mello, \&c.

6- Notas cujo texto é uma mescla do texto da edição portuguesa de Beauchamp e de considerações do próprio Abreu e Lima, como, por exemplo, a nota VI, 258 que é em parte cópia da edição portuguesa de Beauchamp (VII, 242/43) e parte de autoria do próprio Abreu e Lima (trecho que apresento sublinhado):

O Governador Victor Hugues para disfarçar a covardia, ou pelo menos negligência, com que mal tinha defendido a Colônia, desculpou-se em França dizendo que os Portugueses, logo que saltaram em terra, foram incendiando as habitações, e sublevando os escravos contra seus senhores com a promessa de liberdade. Este fato, além de inverossímil por suas funestas conseqüências, foi desmentido por um conselho de inquirição, a que de parte do governo francês se mandou proceder em Caiena, onde os habitantes não acusam os Portugueses de semelhante atentado, e criminam muito de indolente e desanimado aquele Governador. Com a aquisição deste território, avançavam os limites do Brasil até a foz do Marony; e assim permaneceram até que foi a Colônia restituída à França ( 8 de Novembro de 1818) pelo Tratado de 28 de Agosto de 1817, em execução do artigo 107 da Ata do Congresso de Viena, firmada em 9 de Junho de 1815. O não se terem demarcado os limites consignados no artigo primeiro daquele Tratado, logo depois da restituição de Caiena, pela negligência do Governo Português, deu lugar à luta diplomática em que nos achamos empenhados até o corrente ano (1841) com a França sobre a ocupação do ponto do Amapá por esta potência. - Deus permita que sejamos agora mais prudentes para evitarmos no futuro comprometimentos de outra natureza, fixando de uma vez para sempre os nossos limites naturais, segundo se acha convencionado no referido Tratado de 1817.

7- Notas cujo texto é uma mescla da nota da tradução portuguesa e de considerações do próprio Abreu e Lima, como, por exemplo, a nota IV, 169 que é em parte cópia da 
nota do tradutor $(\mathrm{V}, 111 / 12)$ e em parte de autoria do próprio Abreu e Lima (trecho que apresento sublinhado):

Foi este sucesso por todas as circunstâncias notável, pois a divisão Holandesa compunha-se de mil e quinhentos homens, e se lhe haviam agregado oitocentos Índios Potiguares destros e bem disciplinados com oficiais práticos; e Vieira apenas tinha mil e duzentos homens com poucas munições e menos disciplina, e só perdera oito mortos e trinta e dois feridos, em tanto que o campo ficara juncado de mortos e feridos da parte dos inimigos. Tais foram as conseqüências desta ousada empresa, que fazia antever o triunfo da causa brasileira.

8- Notas cujo texto é uma mescla do texto de Beauchamp, acrescido da nota do tradutor português e concluída por Abreu e Lima - como, por exemplo, a nota III, 122, que é em parte cópia da nota do tradutor (trecho que apresento em negrito); parte cópia do texto da edição portuguesa de Beauchamp (III, 118, trecho que apresento em itálico); e parte do próprio Abreu e Lima (trecho que apresento sublinhado):

Brito Freire avalia esta perda em trinta milhões, assim das fazendas carregadas nos navios como das recolhidas nos armazéns; a tudo porém puseram fogo seus próprios donos, com as casas de toda a povoação, por ordem do General. À vista do incêndio choraram os Holandeses a destruição destes ricos despojos, de que Matias de Albuquerque acabava de privá-los. $\underline{\mathrm{O} \text { saque de Olinda também não foi tão considerável, como era de }}$ esperar, porque os habitantes levaram consigo a maior parte de suas preciosidades retirando-se para o interior.

9- Notas cujo texto é integralmente de autoria de Abreu e Lima, como, por exemplo, a nota VI, 284:

"Meu pai foi preso ao anoitecer de 26 de Março [...]". 
Ao finalizar a identificação dos tipos de notas do extenso conjunto de notas da primeira edição pude perceber a importância de lançar um olhar sobre as notas que permaneceram nas edições em um só tomo. As dezessete que restaram das 99 notas iniciais tratam de dúvidas sobre a grafia de nomes próprios, o número das capitanias hereditárias, a definição de mameluco, a descoberta das minas de ouro e a ação dos baianos quando da invasão holandesa; tratam ainda de dúvidas a respeito dos dados biográficos de Antônio Felipe Camarão, Henrique Dias, André Vidal de Negreiros e D. João VI, por exemplo. ${ }^{56}$ Consequientemente, foram excluídas as que ampliavam os temas apresentados; as que apresentavam opiniões divergentes sobre um mesmo acontecimento, incluídas aí as do próprio autor; as remissivas ao próprio texto; as que dialogavam com o leitor imaginado; em resumo, as mais expressivas, aquelas que permitiam autor tanto revelar erudição e conhecimento da produção historiográfica quanto ultrapassar talvez os limites de um compêndio!

A leitura das 99 notas iniciais permite concluir ainda que uma parte significativa dos temas nelas abordados guardava estreita relação com questões, idéias e projetos defendidos por Abreu e Lima, particularmente nos periódicos que publicou - Torre de Babel, Arca de Noé e Raio de Júpiter -, e em outros nos quais colaborou, desde que regressara à Corte imperial. Segundo o próprio autor, elas serviam para expor e, sempre que possível, esclarecer questões controversas, - metodologia que utilizou em todos os capítulos, inclusive naqueles em que não compendiou Beauchamp, e sim outros autores. E também, embora não o diga expressamente, para emitir juízos a respeito do que então se chamava "os negócios do Império".

Alguns exemplos, embora extensos, talvez ajudem a demonstar o que afirmo aqui; ajudarão, por certo, a melhor compreender como a exclusão das notas a partir da $2^{\mathrm{a}}$. edição "alteraria" a compreensão do texto dos "Capítulos", embora este não tivesse sido alterado formalmente.

\footnotetext{
56 O Anexo IV apresenta a localização das notas nas edições de 1843 em dois tomos e um tomo, respectivamente.
} 
Logo no capítulo I. 2 - "Primeiras explorações das terras do Brasil", ao relatar o envio da segunda esquadra por D. Manuel I, o autor ressalta a existência de opiniões diversas em relação à questão: "[...] conquanto não concordem todos os escritores sobre o comandante desta segunda expedição, convêm muitos em que fora Cristóvão Jacques". E complementa por meio da nota:

O Senhor Francisco Adolfo de Varnhagen, em suas notas ao Diário de Pero Lopes de Souza, se inclina a crer que o comandante desta frota fora Fernão de Noronha, descobridor e primeiro donatário da ilha do mesmo nome, e não Cristóvão Jacques, como outros supõem; o que se acomoda em boa parte com Góes, Gabriel Soares e Osório (I, 7).

Após ter lido o Diário de Pero Lopes de Souza e ter considerado a proximidade existente entre o mesmo e os escritos de Góes, Gabriel e Osório sobre o assunto, o autor declara, de forma polida, discordar de Varnhagen porque empreendeu estudos e leituras que tornaram suas convicções mais firmes. No entanto, logo a seguir, em uma extensa segunda nota que ocupa quase duas páginas do livro, ao tratar de outro ponto controverso, o tom muda. O que a nota anterior apenas insinuava, aqui se revela plenamente:

Omiti falar em Américo Vespúcio, e segui literalmente o padre Ayres Casal na sua Corografia Brasílica, e como ele também penso que o nauta florentino não acompanhou Gonçalo Coelho nem a Cristóvão Jacques em suas explorações às costas do Brasil (I, 8).

Segundo Abreu e Lima, se as cartas e um sumário escritos pelo navegador serviam como prova para os que defendiam sua participação, era preciso notar que nelas "há mais de exageração do que de realidade [...]"; se os escritores portugueses do século XVI nada escreveram sobre Vespúcio ter trabalhado para a Coroa portuguesa, é preciso considerar esse silêncio. E, em prosseguimento, ressalta o fato de Varnhagen ter opinião contrária à sua porque para ele "[...] os primeiros inimigos de Américo foram os castelhanos, ciosos do nome América dado ao novo mundo, em que aquele nauta não tivera culpa" (I, 7-8). 
Cioso do dever de fundamentar sua argumentação, o autor de Compêndio fala dos estudos que realizou. Além de ter consultado Robertson, teria encontrado na História geral das viagens precisamente uma passagem que afirmava serem falsas as datas das cartas escritas por Américo Vespúcio, e que tudo não passava de uma impostura. E completava citando o local onde recolhera a informação: tomo 14 , liv, $6^{\circ}$ e $9^{\circ}$, Paris, 1757 . Não de todo satisfeito, Abreu e Lima relembra haver quem considere Vespúcio o descobridor “...de todo o henisfério austral do novo mundo", ainda que o visconde de Santarém em carta publicada no Bulletin de la Société Géographique de Paris, em 1835, tenha negado tal acontecimento. Outrossim, afirma não ser possível ler os escritos de muitos autores modernos sobre esse assunto sem se surpreender. Para corroborar sua opinião, transcreve um pequeno extrato da História Universal de Muller (t. 2, cap. 13), no qual a descoberta do Brasil é creditada a Américo Vespúcio. E finaliza a nota reafirmando objetivos já expressos no "Prefácio", acrescidos de alguns esclarecimentos:

\footnotetext{
Finalmente não sendo o meu objetivo escrever uma história completa senão um compêndio da História do Brasil, em que apenas cabe mencionar os fatos, indicando somente os que podem ser contestados, deixo a outros mais minuciosos a questão, que faz o objetivo desta nota; na qual só quis expor algumas das razões das muitas em que me fundo para pensar como o autor de Corografia Brasílica, cujo texto segui quase literalmente neste capítulo, com as alterações que julguei indispensáveis em consequência de posteriores publicações (I, 10).
}

Assim, logo nas páginas iniciais de Compêndio, de uma só tacada, citando obras diversas e delas oferecendo a referência precisa, mas também de forma irônica, Abreu e Lima demonstrava como eram injustas e falsas as acusações que vinha sofrendo a respeito de seus conhecimentos e erudição, desde que retornara ao Rio de Janeiro.

Como escritor público, homem dedicado às letras, provava não ignorar o que estava sendo produzido sobre a História do Brasil. Como todos os outros escritores, frente a uma controvérsia, fazia escolhas calcadas em autores antigos e modernos. Ao modo de um compendiador, exercitava o que, por certo, entendia por crítica. Todavia, seguidamente seus 
opositores o considerariam um escritor leviano, que não possuía a erudição e o conhecimento que insistia em demonstrar.

Não obstante, a leitura da terceira nota do mesmo parágrafo do capítulo I permite perceber algumas das qualificações que lhe eram negadas, além de revelar que o autor externava com clareza a posição que defendia, o que a muitos aparecia como uma petulância. Ali, com o intuito de determinar quem era João Ramalho, ele faz referência à Notícia dos anos em que se decobriu o Brasil de Frei Gaspar da Madre de Deus, publicada pela Revista Trimensal do Instituto (v. II, 425), assim como utiliza o Diário da Navegação de Pero Lopes de Souza, para realizar uma análise própria que, às vezes, parece ignorar de propósito os estudos realizados por Varnhagen.

Todavia, o pernambucano não ignorava inteiramente o sorocabano, nem poderia fazêlo. Ele não se furta, por exemplo, a atestar a qualidade e importância de Reflexões críticas sobre o escrito do século XVI:

O Sr Varnhagen, restaurando o nome do autor [Gabriel Soares de Souza], fez por certo importante serviço à literatura do seu país, não só por tornar genuíno tão interessante escrito, como por salvá-lo dos vício de tantos traslados manuscritos. As provas, que apresenta o erudito autor das Reflexões, são incontestáveis, tanto pelo que diz respeito ao nome do verdadeiro escritor, como ao título, idade e doutrina da mesma obra (III, 100).

A utilização ampla dos tomos II e III da Revista do IHGB - vale dizer, de textos que haviam passado pelo crivo dos sócios da instituição que se atribuía a tarefa de reunir os documentos e outros materiais necessários à escitura da História do Brasil (Cf. FERRO, 1981) - é comprovada, entre outros, pelas referências e compilação de dados da biografia de Salvador Correa de Sá e Benevides, no tomo III; do texto sobre a transferência da capital para o Rio de Janeiro e dos vice-reis até 1808, contido no tomo II; e das indicações Desembargador Silva Pontes sobre Palmares no tomo III. 
Em inúmeras notas o narrador dos acontecimentos se aproxima do leitor, como se o convidasse a participar do texto emitindo opiniões e extravasando suas emoções e sentimentos, como é possível perceber de algumas das notas a seguir destacadas:

1- "Os leitores se lembrarão de que a primeira invasão dos Holandeses na Bahia fora em 1624" (IV, 198);

2- ao narrar o avanço de João Fernandes Vieira sobre o Engenho de With, quartel general do comandante holandês, em seguida à batalha do Monte das Tabocas, o autor comenta em uma nota a respeito da edificação que, à época da redação de Compêndio, era conhecida pelo nome de Casa Forte. Nutrida em reminiscências individuais, a nota apelava a sentimentos que oscilavam entre o antigo nativismo pernambucano e o novo sentimnto nacional:

Esta habitação pertence à minha família, há mais de trinta anos. Está situada no limite da extensa planície, que vai desde a Boa Vista até as colinas do Monteiro e de Apipucos. Foi meu pai quem derribou as antigas paredes do edifício, que serviu nessa ocasião de casa forte aos Holandeses (donde lhe veio o nome que ainda conserva), e sobre os mesmos alicerces edificou a casa nobre que hoje existe. A maior parte das vigas sobre o que pousava o primeiro andar estavam calcinadas, e por todo o solo, e mesmo encravada nas paredes, se acham muitas balas de ferro de mosquetaria, pedaços de espada e lanças, que serviram nessa ocasião provavelmente de instrumentos de morte para muitos infelizes. Em diversas escavações que se fizeram encontraram sempre os mesmos vestígios (IV 172);

3- ao recomendar a leitura de um extrato "que nos parece de grande importância para a história pátria" sobre "o projeto de revolução em Minas", publicado no tomo III da Revista Trimensal do Instituto (V, 245);

4- ao concordar "perfeitamente com o Visconde de S. Leopoldo quando diz que nem por esta união gozamos de mais tranquilidade" ao tratar da conquista da Banda Oriental do 
Uruguai, posteriormente incorporada ao Império do Brasil sob o nome de Província Cisplatina ( nota - p. 267);

5- ao externar suas preferências por alguns personagens, como Domingos José Martins "personagem mais interessante de todo esse drama [a "Revolução de Pernambuco", em 1817], cuja peripécia foi mais rápida do que se podia imaginar” (VI, 278) - e João Fernandes Vieira - "tal era o mais formidável inimigo dos Holandeses; tal era o mais denodado campeão da independência de Pernambuco" (IV, 179);

6- ao anunciar ter resolvido copiar "por ser de sumo interesse o conteúdo da capitulação celebrada entre os Portugueses e os Holandeses na cidade do Recife [...] o auto e o documento autêntico, como vem na Epanáfora de D. Francisco Manoel de Mello" (IV, 199), assim como o Decreto assinado por D. João VI em 7 de março de 1821, no qual anunciava sua intenção de voltar a Lisboa, por ser "sem dúvida um documento muito interessante para a história daquela época" (VI, 313); e ainda

7- ao propor ao leitor uma espécie de participação em uma decisão crucial, como a da transferência da sede da Monarquia portugesa para a América:

O Padre Antônio Vieira já tinha lembrado este arbítrio a D. João IV, e antes dele o jesuíta Câmara a D. Sebastião. Diz-se também que o Marquês de Pombal o sugerira a D. José I; outros porém asseveram que fora D. Luiz da Cunha. Na grande luta que a Europa se achou empenhada no fim do século passado, o célebre Pitt concebeu a idéia da trasladação da Casa de Bragança para o novo hemisfério, como se colige de um opúsculo daquele ministro, que se acha traduzido na nossa língua. Esta resolução, que parecia momentânea, era, pois o resultado de um plano, há muito concebido pelos ingleses, que em política são os melhores mestres, como tinham sido os jesuítas, que primeiro o aconselharam. O que teria sido do Brasil se D. Sebastião, seguindo o conselho do padre Câmara, em vez da expedição da África em que ele e seu reino se perderam, tivesse vindo fundar uma monarquia deste lado do Atlântico? Quais teriam sido os destinos de nossa pátria? (V, 253/4). 
É também por meio das notas que a bibliografia citada no "Prefácio" é acrescida de outros autores e outras obras. Por outro lado, embora Abreu e Lima faça referência, de quando em vez, a um ou outro documento original, é possível constatar que a escrita de Compêndio não resultou de pesquisa documental inovadora, e nem a isso se propunha.

As notas de pé-de-página de Compêndio cumpriam ainda uma função acessória: por meio delas, os leitores da edição em dois tomos eram convidados a ler os "Documentos em apenso ao Compêndio da História do Brasil”. Será deles que tratarei a partir de agora.

Autos, decretos, representações, cartas, falas reais, petições, instruções, manifestos, editais, proclamações, portarias ministerais, convenções, mensagens, peças oficiais e notícias são reproduzidos em 192 páginas, em seqüência cronológica, organizados em 28 conjuntos identificados pelas letras do alfabeto. ${ }^{57}$ Com exceção dos quatro primeiros, todos os demais documentos referem-se às matérias presentes no segundo tomo: são quarenta e três documentos a respeito da "história moderna do Brasil", dos quais 35 ajudam Abreu e Lima a narrar os acontecimentos cruciais que conduzem à emancipação política do Brasil, pondo em destaque a figura de D. Pedro, quer como regente, quer como primeiro imperador do Brasil, culminando com a Abdicação.

Ora, a decisão de apensar ao "Texto principal" um corpo tão alentado de documentos expressava, provavelmente, a intenção do autor de possibilitar a seu leitor aderir de modo mais ativo aos argumentos que sustentava. Em suas próprias palavras, eles tanto serviam para formar um "pecúlio de doutrinas e fatos" (vi) quanto "para comprovar muitos feitos, que pela diuturnidade passam hoje por meramente fabulosos, ou que virão a parecê-lo no futuro, se correrem sem provas de sua realidade" (viii).

\footnotetext{
${ }^{57}$ O Anexo IV reproduz a relação dos "Documentos em apenso".
} 


\section{QUADRO IV \\ DISTRIBUIÇÃO TEMÁTICA DOS DOCUMENTOS}

\begin{tabular}{|c|l|c|}
\hline Tomos & \multicolumn{1}{|c|}{ Temas } & Número de documentos \\
\hline Tomo I & A capitulação dos holandeses & 1 \\
\hline Tomo I & Reinado de D. João VI & 1 \\
\hline Tomos I e II & D. Pedro regente do Brasil & 19 \\
\hline Tomo II & Reinado de D. Pedro I & 3 \\
\hline Tomo II & No tempo das regências & 5 \\
\hline Tomo II & Segundo Reinado & \\
\hline
\end{tabular}

O total de documentos a respeito de acontecimentos relacionados à atuação de D. Pedro, como regente e primeiro imperador, contrasta fortemente com o número reduzido de documentos referentes ao último capítulo, a época que abrange o Período Regencial e os momentos iniciais do governo pessoal de D. Pedro II: apenas oito! Um contraste que se amplia caso recordemos que o autor já observara que, no que tange a obras a serem compendiadas, "nada havia escrito desta época". Parecendo situar-se entre uma "tarefa paradoxal" (Gagnebin) e a redação de um "testamento político" (Rivas), Abreu e Lima não hesita em se apresentar, naquela oportunidade, como um cronista. Sustenta, então, que o historiador só não é um compilador quando escreve sobre "os fatos presenciais". Quando escreve sobre a história do seu tempo, tratando dos vivos e dos mortos recentes, não deve recorrer a diversos autores, mesmo que eles existam. Recorre, pois, à própria experiência vivida e à memória que dela elaborou. E não se exime de emitir seus juízos, valores e preferências a cada página. Desde então, também em contraste com a parte imediatamente anterior, os documentos apresentados parecem cumprir um papel pedagógico na afirmação da ordem monárquica.

Revela-o, por certo, a seleção de documentos referentes a essa última época. Dos oito documentos, apenas três relacionam-se ao período das Regências ${ }^{58}$. Era seguramente a

\footnotetext{
${ }^{58}$ São eles a "Proclamação em nome da Assembléia Geral aos Povos do Brasil, dando conta dos acontecimentos do dia 7 de Abril de 1831, e da nomeação da Regência Provisória, e recomendando o sossego e a tranqüilidade pública"; o "Manifesto do Coronel Bento Gonçalves da Silva, cabeça da Rebelião do Rio Grande do Sul,
} 
avaliação que Abreu e Lima fazia do período - um período de anarquia, no qual a longa menoridade do segundo imperador ameaçara não só a continuidade monárquica, mas também a integridade territorial do Estado imperial - que produzia um silêncio documental. Uma avaliação negativa expressada na utilização de um conjunto de expressões estigmatizadoras na composição do texto de um capítulo que narrava uma experiência histórica que, sob uma outra perspectiva, pode ser avaliada como inovadora e enriquecedora da liberdade. Assim, a parte 3 do capítulo VIII, especialmente da página 98 à página 100, para dar um único exemplo, é copiosa em expressões como "soldadesca indisciplinida", "furor dos partidos", "revolução" (significando indisciplina e anarquia), "guerra civil", "homens quase selvagens", "tropas sediciosas", "cenas de carnagem e de horror que tantas vezes têm ensangüentado a nossa Província”, entre inúmeras outras, que talvez ajudem a explicar o que chamo de um silêncio documental. Muito provavelmente o autor preferia votar ao esquecimento documentos - como o Ato Adicional de 1834, o Código do Processo Criminal e outros - que permitiriam recordar o que, no seu entender, fora a nefasta experiência descentralizadora; por certo, o "General de Bolívar" preferia provocar ou reforçar em seus leitores temor ou medo político e social em relação à experiência regencial, como era comum, aliás, nos embates argumentativos, por meio dos mais diferentes suportes, à época. ${ }^{59} \mathrm{O}$ autor de Compêndio não deixaria de estigmatizar também a atuação dos políticos regenciais que, a seu juízo, dominavam o governo imperial na Corte. Eram eles, os responsáveis também em proporções não pequenas pelas inúmeras revoltas, rebeliões e sedições que dilaceravam o Império do Brasil. Falando do Pará, dizia "que a sua existência política tem sido um constante interregno da Constituição: ora lançada nos vórtices das revoluções, ora entregue a autoridades bem infensas ao seu bem estar e prosperidade. [...] Quem tiver a paciência de recorrer a lista de todos os Presidentes e Comandantes de Armas do Pará...verá que quase todos foram vítimas ou concorreram para os distúrbios que têm assolado aquele malfadado país" (VIII, 104). ${ }^{60}$ Em outra oportunidade, não nas páginas de Compêndio, mas por meio de uma carta que dirige ao Imperador a respeito dos

publicado no dia 25 de Setembro de 1835"; e as "Peças oficiais relativas à renúncia que fez o Senador Diogo Antonio Feijó do cargo de Regente, no dia 19 de Setembro de 1837".

${ }^{59} \mathrm{Cf}$. a respeito do uso do medo como instrumento de exercício de poder político, Hirschman (1992).

${ }^{60}$ A contundência da acusação feita aos Presidentes da província paraense fez com que um deles, José Joaquim Machado de Oliveira, se dirigisse ao IHGB, por meio de um requerimento, repelindo a acusação que lhe fora feita e solicitando que aquela instituição, por ter deliberado anteriormente "fosse submetido ao exame de uma comissão especial o Compêndio da História do Brasil", que a dita comissão analisasse "a parte histórica do mesmo Compêndio que é relativa ao Pará, e contra a qual reclamo". Argumentava o requerente que agia em defesa da verdade histórica, "que o Instituto tem por máximo dever sustentar". Sessão no. 115, em 16 de novembro de 1843. Ata da reunião. Revista do IHGB, tomo V, no. 20, p. 536-538. 
sucessos do Rio Grande do Sul, não hesita em afirmar que entre as causas da "rebelião" naquela província meridional encontrava-se a ação do partido Moderado dominante no Rio de Janeiro; e não perde a oportunidade para oferecer ao imperador D. Pedro II os seus serviços militares para pacificar a província, à maneira como servira a Bolívar. ${ }^{61}$

Abreu e Lima parecia não duvidar. Somente a instituição monárquica e a figura emblemática do Imperador poderiam pôr fim ao que caracterizava como uma anarquia. Do seu esforço pela restauração do poder monárquico, o qual em determinada oportunidade o levou a defender a regência da Princesa D. Januária e, em outra, a antecipação da maioridade, ${ }^{62}$ resultaria a sua caracterização como um "caramuru" ou "restaurador" por seus adversários políticos. Em seu último capítulo, as páginas de Compêndio também seriam a tribuna de onde não apenas defenderia o princípio monárquico, mas também se defenderia do que, então, era uma pecha política, em uma espécie de "testamento político". O texto é longo, mas elucidativo:

Se nos enganamos em nossas opiniões acerca dos futuros destinos do país, se os nossos temores eram ou não infundados pela sorte da Monarquia debaixo de uma longa menoridade, e exposta durante ela a todos os furores das paixões populares, o tempo o decidirá, quando houverem desabrochado todas as sementes que se plantaram nos nove anos decorridos desde a Abdicação até a Maioridade do Senhor D. Pedro II. Por ora só diremos que nunca tivemos em vista que o Senhor Duque de Bragança viesse ao Brasil para ocupar o Trono, que tão voluntariamente havia deixado; e só quem não o conhecesse poderia imaginar semelhante indignidade. O furor das facções fez danos à denominação de Restauradores; porém a volta daquele Augusto Senhor tinha para nós a grande vantagem de assegurar a Monarquia e o Trono de seu Filho pela sua presença no Brasil, do mesmo modo que acabava de assegurar para a Rainha de Portugal a Coroa que havia igualmente abdicado, sem que merecessem o apodo de Restauradores os que o tinham coadjuvado em tão glorioso empenho. O partido Caramuru exerceu

\footnotetext{
${ }^{61}$ José Inácio de Abreu e Lima. Memorial reservado para ser apresentado a S. M. O Imperador pelo General Abreu e Lima. 2 de agosto de 1841. Lata 11: Pasta 5.

${ }^{62}$ Cf. os artigos em Raio de Júpiter, publicados em 1836. Sobre o golpe da Maioridade, cf. Octavio Tarquínio de Sousa. "A Maioridade (Revolução parlamentar de 22 de julho de 1840)". In: Três golpes de estado. Rio de Janeiro: José Olympio, 1957, p. 133-214.
} 
bem pouca influência no país, e acabou inteiramente com a morte do duque de Bragança a 24 de Setembro de 1834 (VIII, 91). ${ }^{63}$

Se o autor reservara para os nove anos das Regências apenas três documentos, para os doze meses do governo pessoal do segundo imperador apresenta cinco documentos. Destes, a "Proclamação da Assembléia Geral pela qual se faz constar ao Povo do Brasil que o Senhor D. Pedro II foi declarado Maior, e entra no exercício que pela Constituição lhe compete" era, em larga medida, uma escolha previsível. Somente pode-se dizer o mesmo dos outros quatro documentos selecionados caso se tenha em vista o sentido pedagógico que o autor lhes atribuía, o qual já se apresentava na escolha inicial. Assim, a "Notícia do ato da Coroação e Sagração do Senhor D. Pedro II no dia 18 de Julho de 1841", a "Coroa cívica que a Guarda Nacional do Rio de Janeiro ofereceu ao Senhor D. Pedro II no dia 19 de Julho, imediato ao da sua Coroação", a "Descrição da Coroa cívica" e a "Descrição da Varanda do Paço, que serviu para o majestoso ato da Coroação do Senhor D. Pedro II" eram documentos que serviam para pôr em destaque fausto e nobreza, pompa, hierarquia e submissão - ou seja, o triunfo do princípio monárquico. Considerados da ótica pessoal de Abreu e Lima, de suas relações com o Império ${ }^{64}$, o conjunto daqueles cinco documentos servia para demonstrar o provável triunfo - "os futuros do Brasil [...] podem anunciar-se como muitos lisonjeiros debaixo do reinado do Segundo Pedro" - de algumas de suas opções, após um "purgatório" que durara dez anos. Considerados da ótica do autor e de suas intenções, eles eram o testemunho derradeiro do exercício de uma expansão para dentro.

\footnotetext{
${ }^{63}$ Ao tratar da Abdicação, Abreu e Lima traça o que chamou de "Caráter de D. Pedro", não deixando de dialogar, ainda desta vez, com os opositores de ambos: "D.Pedro não era tirano; ninguém, a não ser algum caluniador, o designou como tal. Seus erros foram grandes, porém as suas intenções eram sempre as mais puras em benefício do país; desgradaçadamaente achou-se quase sempre só ou mal acompanhado. Abraçando de boa fé a causa da Independência e do governo representativo, ninguém lhe levou a palma em sustentar a primeira ou em respeitar o segundo. Dotado de grande talento e valor, entusiasta pela liberdade mas sem prudência, estava melhor calculado para libertar o Brasil do que para dirigir a subseqüente marcha do seu Governo. Apesar de todos os seus erros e dos de seus Ministros, o Brasil, durante os dez anos da sua administração, fez certamente mais progressos em inteligência e civilização do que nos três séculos decorridos desde a sua descoberta até a partida d'El-Rei para Portugal em 1821". (VII, 77).

${ }^{64}$ Em inúmeras ocasiões me perguntei a respeito das relações - políticas, culturais, sentimentais - de Abreu e Lima com o Império, durante o seu período de exílio. Recebendo informações de variada procedência e por meio dos mais variados suportes, o filho do padre Roma parece ter mantido uma relação ininterrupta, marcante e acentuada, bem maior que a distância geográfica e política que separava o Império do Brasil das jovens repúblicas hispanoamericanas. Na história deste pernambucano há um sentimento marcante de pertencimento à pátria, somado a uma convicção política que vai sendo burilada tanto pela experiência vivida e pela erudição como por sentimentos e emoções.
} 
Mas não apenas por meio de documentos relativos ao tempo de consolidação monárquica, ou seja, ao tempo em que vivia, Abreu e Lima buscava intervir na vida presente. Ele o fez também por meio do único documento referente a um acontecimento do que chamamos hoje o período da colonização - ou a "história antiga" do Brasil, como costumavam dizer alguns dos membros do IHGB: as Invasões Holandesas. No momento em que aquele acontecimento começava a ser monumentalizado pela nascente historiografia brasileira, Abreu e Lima ia ao seu encontro também por meio de um documento que punha em evidência um tema que o motivava, emocionava e preocupava ao menos desde os sucessos de 1817: a anistia.

Após relatar a conferência que antecedeu a capitulação, sua assinatura, a retomada do porto do Recife e da cidade Maurícia, com todos os fortes de mar e terra, e a entrega das "províncias do Rio Grande, Paraíba, Ceará, Itamaracá, e da ilha de Fernando”, o autor informa, ainda no texto do capítulo, que

\footnotetext{
"uma inteira anistia foi concedida a todos os brasileiros comprometidos no partido holandês, ficando deste modo livre para sempre o Brasil do jugo estrangeiro." (IV, 199).
}

E remete o leitor para uma nota: "Como julgamos de sumo interesse o conteúdo da capitulação celebrada entre portugueses e holandeses na cidade do Recife, copíamos o auto e documento autêntico, como vem na Epanáfora V de D. Francisco Manoel de Mello. (cf. Anexo V, letra A)."

O tema da anistia estava posto. A leitura do parágrafo inicial do documento revela que a autoridade portuguesa "dá por esquecida toda a guerra que se tem cometido com os vassalos dos Srs. Estados Gerais das Províncias Unidas, e Companhia Ocidental, contra a Nação Portuguesa, ou seja, por mar, ou por terra, a qual será tida e esquecida, como se nunca houvera sido cometida”, princípio que se desdobra pelos demais parágrafos, bastando-me transcrever aqui o segundo deles: "também serão compreendidas neste acordo todas as nações de qualquer qualidade, ou religião, que sejam; que a todos perdoa, posto que hajam sido 
rebeldes à coroa de Portugal: e o mesmo concede, no que pode, a todos os judeus, que estão no Recife e cidade Maurícia”.

No momento em que o Império do Brasil ainda não debelara inteiramente as revoltas de todo tipo que tinham assinalado o período regencial - as expectativas positivas do autor de Compêndio sendo turvadas pela "guerra civil do Rio Grande, a que só Deus porá termo, segundo vão as coisas no Império" -, os termos da capitulação deveriam ser vistos como um exemplo a ser seguido no presente, guardadas as diferenças, pois falava de um poder político centralizado e forte que oferecia regras e condições claras para o convívio entre os diferentes, sempre sob a égide do Monarca. E daí derivava, por certo, uma lição da História. Anos depois da publicação de Compêndio, Ernest Renan ensinaria que "a essência de uma nação é que todos os indivíduos tenham muito em comum, e também que todos tenham esquecido muitas coisas", chamando a atenção para um jogo permanentemente renovado entre memória e esquecimento, no qual a História cumpriria um papel fundamental (RENAN, 1990, p. 20). ${ }^{65}$

Mas a lição que Abreu e Lima procurava dar ao presente sustentava-se, talvez, em um anacronismo. Se a autoridade portuguesa anunciava um perdão, sob a forma de um esquecimento, a todos aqueles que tinham lutado contra a "Nação portuguesa", e naquele perdão estavam compreendidas "todas as nações de qualquer qualidade, ou religião, que sejam, além de todos os judeus, que estão no Recife e cidade Maurícia”, quem seriam, então, "todos os brasileiros" - de acordo com o texto do capítulo (não o do documento) "comprometidos no partido holandês"? Ou perguntando de outra maneira: a quem o autor de Compêndio denominava “brasileiro" na América portuguesa, em meados do século XVII?

Como em outras passagens, o texto de Compêndio expunha uma contradição. Esta, como outras seriam, pouco tempo após sua edição, objeto de severas críticas pelos membros do IHGB. Configurando uma censura, tais críticas não deixavam de sugerir uma interdição. Como modo de melhor compreendê-las, talvez seja a hora de deixar os documentos, retornando ao texto do "Texto principal", como modo de melhor comprendê-lo também.

\footnotetext{
${ }^{65}$ O texto original é de 1887 (LEVY, 1887, p. 286).
} 
Nos dois capítulos iniciais e na maior parte do terceiro de Compêndio, Brasileiro ${ }^{66}$ é a designação utilizada por Abreu e Lima para identificar os habitantes - "[...] mais de cem nações brasileiras [...]” (I, 27) - do território descoberto por Pedro Álvares Cabral. Toda a parte V do capítulo inicial é destinada à descrição do "Caráter, usos e costumes dos habitantes naturais do Brasil", ocasião em que a designação brasileiro é utilizada em cinco oportunidades: "nem todos os Brasileiros eram antropófagos" (I, 29); “os Brasileiros não são geralmente polígamos, ainda que alguns chefes possam ter diversas mulheres" (I, 32); “As raparigas, antes de casarem, entregam-se sem pejo aos homens livres: seus próprios pais às oferecem aos hóspedes; porém logo que se ligam ao estado de casadas, são fiéis a seus maridos, e o adultério é odioso entre os Brasileiros"(I, 32); "sem outras leis mais que os seus usos, seguindo quase sempre o instinto da natureza, os Brasileiros possuem algumas virtudes sociais" (I, 34); “[...] a arma principal dos Brasileiros é uma clave de seis pés de cumprimento" (I, 34).

Ao identificar os "Brasileiros", as páginas de Compêndio pareciam ecoar as dos primeiros cronistas coloniais, nas quais a descrição do gentio americano era caracterizada por falhas e ausências ${ }^{67}$, gerando inevitavelmente classificações que, ao sublinhar uma inferioridade cultural, criavam a possibilidade e a justificativa para práticas colonialistas. (CUNHA, 1993). ${ }^{68} \mathrm{E}$ tal se revela $\operatorname{logo}$ no capítulo II, ou seja, assim que teve início a colonização propriamente dita. Ao tratar da instalação do Governo Geral, o autor destaca que quando da construção da "nova Capital" [a cidade de Salvador], "o Governador [Tomé de Souza] presidia em pessoa aos trabalhos, e cuidava ao mesmo tempo em regular a administração, atrair os Brasileiros, e civilizá-los" (II, 62). Tarefa hercúlea a que os europeus teriam se dedicado desde então, na qual um papel de destaque coube às ordens religiosas, principalmente os jesuítas. Mas tarefa que, além de parecer não ter fim, muitas vezes revelava que o bárbaro era aquele que acreditava na barbárie: ao tratar da ocupação do Grão-Pará, já no

\footnotetext{
${ }^{66}$ Conforme as regras da época, "Brasileiro" como substantivo próprio aparece no texto sempre com a inicial maiúscula; quando qualificativo, é grafado geralmente com inicial minúscula - "nações brasileiras". Aqui, somente ao transcrever os trechos de Compêndio mantenho a forma original "Brasileiro"; ao falar do brasileiro ou brasileiros, ainda que me referindo aos nativos, utilizarei a inicial minúscula, destacando o termo com itálico.

${ }^{67} \mathrm{Cf}$, entre inúmeros outros, Gandavo: "A língua deste gentio todo pela Costa é uma: carece de três letras: não se acha nela F, nem L, nem R, cousa digna de espanto, porque assim não têm Fé, nem Lei, nem Rei; e desta maneira vivem sem Justiça e desordenadamente".

${ }^{68}$ Edward W. Said chama a atenção para o fato de o colonialismo ser também uma série de discursos, científicos ou não, que organizam a hegemonia cultural e geopolítica de uma região sobre outras (SAID, 1996).
} 
século XVII, o autor relata que Bento Maciel Parente, sob o pretexto de uma sublevação dos nativos, "prendeu vinte e quatro chefes dos Tupinambás, e no mesmo dia e hora mandou-os cortar em pedaços pelos Tapuias, seus implacáveis adversários, servindo-se assim do ódio que entre si nutriam os Brasileiros" (III, 120).

Como é por demais sabido, a maneira de apresentar os primeiros habitantes do território do Império do Brasil não era exclusiva de Abreu e Lima à época; não obstante as diferenças, todos pareciam ecoar os cronistas coloniais. Na História Geral do Brasil de Varnhagen, aqueles habitantes eram apresentados como "essas gentes vagabundas que, guerreando sempre, povoaram o terreno que hoje é do Brasil"; e ainda de modo mais contundente: "de tais povos na infância não há História: há só etnografia. A infância da humanidade na ordem moral, como a do indivíduo na ordem física, é sempre acompanhada de pequenez e miséria" (VARNHAGEN, 1975, p. 24,30). O que diferenciava Abreu e Lima era como os denominava - "Brasileiros". O autor de Compêndio ignorava, propositalmente ou não, o fato de, no século XVI, o nome "brasileiro" designar uma profissão - o traficante de pau-brasil, atribuindo-lhe, anacronicamente, uma polissemia.

Todavia, a denominação brasileiro atribuída aos nativos aparecia naqueles capítulos iniciais como complementar à de português, isto é, à denominação dada aos descobridores e povoadores ou colonizadores da terra. Assim, em poucos exemplos: "Como o terreno que os Portugueses escolheram logo não era vantajoso" (II, 46), ao falar da ocupação da capitania de São Vicente; "Os selvagens reunidos em grande número, e inflamados pelos clamores de Paraguaçu, fizeram encarniçada guerra de destruição e morte aos Portugueses” (II, 55), narrando as ocorrências resultantes das relações entre o donatário da capitania da Bahia de Todos os Santos e o Caramuru; e, ao narrar os sucessos de uma expedição que partira em busca do El Dorado, no início da União Ibérica: “[...] os Portugueses conseguiram cercar os Tapuias, e submetê-los à escravidão" (III, 101).

Contudo, nas páginas de Compêndio, "Brasileiro" não designaria sempre os primeiros habitantes da terra que recebera o nome de Brasil. Ao iniciar com uma expressão significativa - "Até aqui..." - a parte IV do capítulo III, o autor anuncia a seus leitores uma mudança fundamental na trajetória de ocupação do território americano pelos portugueses. O "Até 
aqui" delimitava nitidamente dois momentos, quase duas "épocas", a partir de um acontecimento crucial: as "Invasões Holandesas". 69

Desde as "Invasões Holandesas", e em parte por causa delas, a narrativa começa a mudar. Ela passa a apresentar novos sujeitos; as diferentes capitanias parecem ir se constituindo em pequenas pátrias. Novos personagens irão se situar entre os "Brasileiros" e os "Portugueses". E, em uma espécie de coroamento de uma trajetória, ocorre a transmutação da significação de brasileiro.

É bem verdade que antes mesmo do "Até aqui" um personagem diferente se apresentara, ao lado de "Brasileiros" e "Portugueses", e como resultado do intercurso de ambos. Ao tratar da ocupação da capitania de São Vicente, pondo em relevo mais uma vez a obra missionária, o autor mencionava uma "raça perversa", que tendo nascido "no seio do Brasil nele espalhou mais de uma vez o terror e a desolação" (II, 68). E completava, por meio de uma nota: "Dava-se a esta raça híbrida, isto é, os mestiços descendentes de Portugueses e Brasileiros, a denominação de Mamelucos". Mas não será desta população "sobretudo belicosa", que o autor tratará a partir daqui.

A partir daqui... as páginas de Compêndio começam a ser freqüentadas pelos "Portugueses do Brasil" (III, 113); pelos "habitantes da Bahia" (III, 115) ou "Baianos...", como aparece em nota; pelos "habitantes de Pernambuco" (III, 125) ou "Pernambucanos" (IV, 186); pelo "Paulistas" (V, 208); pelos "Mineiros" (V, 230). Em uma trajetória na qual os tipos e personagens vão se multiplicando à medida que os capítulos se sucedem, muda ou amplia-se o significado atribuído a brasileiro. Considero, aqui, dois momentos.

O primeiro deles. Na luta contra o invasor holandês, destaca-se "o chefe brasileiro Filipe Camarão" (III, 125), ao mesmo tempo que "as milícias brasileiras adquiriam cada vez mais o hábito da vida militar" (III, 130). Em ambos os casos, o qualificativo "brasileiro" já não se refere a um nativo com as características que o distinguiam à época do Descobrimento:

\footnotetext{
69 "Até aqui não têm tido os Portugueses que superar na América senão dificuldades locais; não combateram senão com piratas ou aventureiros destemidos, que não sendo ajudados pelos seus governos, faziam inúteis esforços para se estabelecerem no Brasil. Adversários mais temíveis vão oferecer o espetáculo de uma luta mais renhida" (III, 112).
} 
a este se reservava cada vez mais a denominação "índio bravo". De modo diferente, o nativo que luta ao lado dos "Portugueses" e dos "habitantes de Pernambuco", por ter adquirido "o hábito da vida militar" formando "as milícias brasileiras", passa a ser caracterizado como "índio civilizado", e deles constituía um caso exemplar o "chefe brasileiro Filipe Camarão". Assim, se as denominações "Brasileiro" e "Portugueses" permanecem complementares, em meados do século XVII "Brasileiro" já não possui sua significação original, referindo-se, agora, sobretudo ao nativo incorporado ao processo de colonização, ao passo que a denominação "Portugueses" abrange quer os "Portugueses do Brasil" quer os portugueses do Reino (ou "reinóis", expressão que não aparece no texto de Compêndio). Neste momento, parece encontrar resposta a questão que deixei acima (cf. p.151) a respeito de quem seria "Brasileiro", ao falar da concessão pela "Nação portuguesa" de "uma inteira anistia a todos os brasileiros comprometidos. Ora, no território da América portuguesa, ao lado daqueles que pertenciam a uma "Nação portuguesa", da qual faziam parte "baianos", "pernambucanos", "mineiros", conviviam outras nações, dentre elas uma "nação" brasileira cujos componentes não mais se confundiam com os primeiros habitantes do Brasil. Nativos de origem, eles tinham se tornado "Brasileiros" no movimento da colonização portuguesa, particularmente durante a luta contra o batavo, mas não apenas por obra dela, como o revelava a figura de um Bento Rodrigues de Oliveira. "Brasileiro de nascimento, acostumado desde a mais tenra infância a esta espécie de navegação" (III, 150), ele fora o auxiliar insubstituível que possibilitara a expedição de Pedro Teixeira, que subira o rio Amazonas até Quito, em 1637. Mas não apenas isso: aos "Brasileiros", o autor acrescentava novos elementos, de origem não indígena, como "um mulato nascido em Pernambuco, chamado Domingos Fernandes Calabar", o qual ao passar para o lado do invasor holandês mudara o rumo da guerra em seus primeiros tempos. E complementava, por meio da nota: “...o primeiro Brasileiro que passou para o campo dos Holandeses" (III, 130). Assim como sabia quem não pertencia àquele conjunto: embora destaque como poucos os feitos de Henrique Dias, comandante de um terço de homens negros na luta contra os holandeses, ele o apresenta como "de origem africana e natural de Pernambuco", ou seja, nem "Pernambucano", nem "Brasileiro" nos termos ali considerados.

Das páginas de Compêndio emerge um mosaico: "Portugueses do Brasil", Portugueses [do Reino ou europeus] e "Brasileiros"; "Baianos", "Pernambucanos", 
"Paulistas" e "Mineiros"; escravos, libertos e homens livres; brancos, índios, negros, mulatos e mamelucos; "nações de qualquer qualidade, ou religião". Um mosaico contido em um vasto território. Mas um mosaico que começa a ganhar uma unidade diferente à medida que chego ao final do primeiro volume (ou a um segundo momento). Chama a minha atenção de imediato o fato de o Capítulo V - dedicado à época que se estende de 1654 a 1807 - não apresentar uma única vez o personagem "Português" na enorme quantidade de acontecimentos que preenchem um século e meio da formação do que passa a ser denominada também como "América Portuguesa" (V, 248). Lá estão os "Portugueses do Brasil" e os "Portugueses de Minas" (V, 238), estes atentando contra a ordem do Império português ao se aliarem perigosamente com os Goitacazes; mas os "Portugueses" (entenda-se, do Reino) somente aparecem em eventos fora do território da "América Portuguesa". 70 Em contrapartida, a ausência dos "Portugueses" nas páginas do capítulo possibilitava um novo deslocamento e a ampliação do significado de "Brasileiro", como o revela um trecho referente à administração de Pombal, que por meio de "sábios regulamentos, e vivificando o comércio, ...fazia florescer o Brasil". Para o autor, aquele governante "estimulou o gênio dos Brasileiros, chamando-os aos mais elevados empregos" (V, 237). Em sua nova significação, ela contém, ainda que não as dilua, aquelas identidades geradas pela colonização, as identidades coloniais, as quais se expressavam em denominações como "baianos", "pernambucanos", "paulistas" e "mineiros", ou ainda em outras como "nobreza da terra"71. Difícil dizer se, no texto do capítulo, "Brasileiro" inclui também, como no momento anterior, os nativos civilizados e os mulatos. A favor da possibilidade pode ser recordado que a referência aos (novos) "Brasileiros" é antecedida por uma outra que não deixava de expressar uma das mais caras aspirações de Abreu e Lima: "[Pombal] favoreceu todas as classes, especialmente os Índios, os escravos e homens de cor, por sábias pragmáticas". Uma referência que se desdobrava em nota que, ao transcrever parte da Lei de 6 de junho de 1755, sublinhava que "os Índios, como livres e isentos de toda a escravidão, podem dispor de suas pessoas e bens [...] viverem na paz e união Cristã e na Sociedade Civil [...] para gozarem de todos as honras, privilégios e liberdades de que os meus vassalos gozam atualmente conforme as suas respectivas

\footnotetext{
${ }^{70} \mathrm{O}$ que acontece em duas oportunidades: na referência aos "Portugueses degenerados" das Índias Orientais (V, 202 nota) e a acontecimentos no Rio da Prata em 1776 (V, 240).

${ }^{71}$ Sobre a controversa questão das idientidades coloniais, e das denominações a que parecem recorrer, talvez seja interessante lembrar que Capistrano de Abreu (1954) falava de uma "consciência capitanial" por oposição a uma "consciência nacional"; cf. ainda Figueiredo (2003); Mello (1986), sobre a "nobreza da terra" pernambucana; e István; Pimenta (2000). Para a experiência da América espanhola, cf., entre inúmeras outras possibilidades, Guerra (2003).
} 
graduações e cabedais". Contra a possibilidade ou, melhor dizendo, contra parte dela, a referência "a gente de cor na Bahia", sem qualquer associação com "Brasileiro", ao mencionar uma revolta ali tramada em 1801, à semelhança da "conspiração" de Minas Gerais, em 1789, em uma nota ao final do texto $(\mathrm{V}, 247) .^{72}$

No capítulo seguinte, que recobre a época que se estende de 1808 a 1821, "Brasileiro" parece completar uma trajetória, aproximando-se finalmente do significado que lhe era atribuído no Império do Brasil, em meados do século XIX. Ali, como se completasse uma viagem redonda, na qual o ponto de chegada é o ponto de partida, Abreu e Lima retoma a distinção entre "Portugueses" e "Brasileiros" - mas uma viagem na qual o autor não raro confunde o leitor, ou ao menos o desagrada, por sua tentativa, talvez, de filiar os "últimos Brasileiros" (isto é, os do capítulo VI) aos "primeiros" (isto é, os do capítulo I).

Ali, o autor diz ser "impossível descrever o entusiasmo com que Portugueses e Brasileiros receberam e festejaram o chefe da Casa de Bragança” (VI, 255), que desembarcara em solo baiano em janeiro de 1808. Contudo, o júbilo comum não impedia o narrador de destacar o valor dos "Brasileiros": por ocasião da conquista da Guiana Francesa, "os Brasileiros entraram triunfantes na praça, na qual se arvorou a bandeira nacional" (VI, 258). Do mesmo modo que não o impedia de criticar os "Portugueses", isto é, aqueles que tinham vindo para o Brasil com a Família Real: "um enxame de aventureiros, necessitados e sem princípio, acompanhou a Família Real; foi necessário portanto admiti-los nos diferentes ramos da administração" (VI, 260). Uma alegria comum que não tardaria em se transformar em rivalidade - "existindo desde muito tempo a rivalidade entre Portugueses e Brasileiros" (VI, 260) -, conduziu à revolução em Pernambuco: apesar do fracasso e da repressão violenta sofrida pelos "patriotas pernambucanos", e que o atingiu pessoalmente e à sua família, 1817 prenuncia 1822, mediados pelos acontecimentos de 1820 em Portugal. Uma transformação se delineia, então: o narrador vai se transformando em personagem de sua narrativa, como "Pernambucano" e "Brasileiro" a um só tempo. A narrativa dos sucessos da Revolução do Porto o revela, entre outras passagens: "era chegada pois a ocasião em que devíamos tirar a

\footnotetext{
${ }^{72}$ A incorporação da chamada "população de cor" à sociedade imperial, de modo pleno, foi preocupação recorrente na vida de Abreu e Lima, conforme já destacado em diferentes oportunidades. Em arenas diversas travaria também esta luta, bastando lembrar aqui as proposições contidas em Bosquejo.
} 
desforra, prestando-nos a seus interesses [dos revolucionários do Porto], enquanto não podíamos fazer valer os nossos" (VI, 296).

Com a proclamação da Independência em 1822 chego ao segundo tomo de Compêndio. Mas não seguirei por suas páginas, agora. Retorno ao primeiro tomo; releio a frase de abertura do "Prefácio": "Um país, que apenas conta vinte anos de existência como nação, não pode ter literatura propriamente sua...”. Abreu e Lima é explícito: os brasileiros em quaisquer das significações que foram atribuídas ao mesmo significante - preexistiram à nação brasileira, surgida com a emancipação política. Mas nem todos entendiam assim.

Quase três décadas antes, à época da permanência da Corte portuguesa no Rio de Janeiro, pelas páginas do seu Correio Braziliense, editado em Londres, Hipólito José da Costa chamava "brasileiro" ao português que, tendo vivido e enriquecido no Brasil, retornara à terra de origem; "brasiliense", ao natural do Brasil; e "brasiliano", ao indígena. Com a emancipação política, a denominação "brasiliense" não se imporia, e sim brasileiro para designar aqueles que constituíam o novo corpo político - o Império do Brasil, em meio a outras disputas então travadas no campo simbólico. ${ }^{73}$ Todavia, as coisas não eram tão simples assim: se para muitos os brasileiros passavam a existir desde que passara a existir um novo corpo político, conforme o revela o texto da Constituição de 1824 - "são cidadãos brasileiros os que no Brasil tiverem nascido, quer sejam ingênuos ou libertos" -, para outros, como o naturalista francês Auguste de Sait-Hilaire, que percorria as províncias do novo império àquela época, "havia um país chamado Brasil, mas não havia brasileiros". A partir de seu ponto de vista, ele frisava que a independência política criara a liberdade em face da dominação metropolitana, mas não fora capaz de gerar uma nação moderna constituída por indivíduos livres e iguais perante a lei, os quais somente assim participariam do que um autor denomina uma "comunidade imaginada" (SAINT-HILAIRE, 1974). ${ }^{74}$

José Bonifácio de Andrada e Silva parecia aproximar-se das preocupações de SaintHilaire. Como já sabemos, ele dissera que "brasileiro é todo aquele que adotou a nossa

\footnotetext{
${ }^{73} \mathrm{Cf}$. a respeito das disputas em torno de nomes, Ricouer (2002). A propósito do triunfo das denominações "brasileiro" e "Império do Brasil"cf. Mattos (2005).

${ }^{74}$ Sobre o conceito de "comunidade imaginada", cf. Anderson (1989).
} 
causa", ou seja, a causa da emancipação política; mas para ele a emancipação política era apenas o momento inicial da constituição de uma nação, devendo necessária e obrigatoriamente desdobrar-se em uma outra emancipação: "é tempo de irmos acabando gradualmente até os últimos vestígios da escravidão entre nós, para que venhamos a formar em poucas gerações uma nação homogênea, sem o que nunca seremos verdadeiramente livres, respeitáveis e felizes”. Ele parecia, assim, resgatar algumas das proposições do Marquês de Pombal há pouco expostas, as quais eram também do inteiro agrado de Abreu e Lima. Ora, a associação feita por José Bonifácio entre a questão da nação brasileira e a questão da escravidão era complexa, difícil e polêmica, por afetar interesses sociais e políticos fortemente estabelecidos. Mas o velho Andrada entendia que somente a resolução da questão da escravidão permitiria a constituição de "um todo homogêneo e compacto, que não se esfarele ao pequeno toque de qualquer nova convulsão política" (ANDRADA E SILVA apud SOUZA, 1945). Abreu e Lima não desconhecia a complexidade e dificuldade daquela associação, mas a seu respeito tinha uma compreensão diversa, exposta em Bosquejo. Nas páginas do texto publicado em 1835, em pleno calor dos acontecimentos regênciais, ele argumenta de modo contundente que "não pode haver perfeita liberdade política, sem a civil e a religiosa" e que as "palavras escravidão e direito são contraditórias e se excluem mutuamente", pondo em destaque os horrores e mazelas daquela instituição. ${ }^{75}$ Todavia, por ter em consideração as condições específicas do Império do Brasil, e ainda as dos novos países americanos surgidos com a emancipação política, ele diz poder "deduzir duas coisas: $1^{\text {a }}$ - que a emancipação dos escravos, ou a liberdade civil na América é de impossibilidade absoluta por muitos anos, principalmente no Brasil; $2^{\mathrm{a}}$ - que sem a liberdade civil não poderemos aspirar ao complemento da liberdade política" (p. 54). E reafirmando seu modo polêmico de argumentar: "confessemos ingenuamente, e não tenhamos rubor em confessá-lo,

\footnotetext{
75 "Eis aí uma questão implícita, que não devia tocar-se na América, dirá algum visionário liberal; outro me tachará de cérebro exaltado, e de inovador pedante; aquele me julgará subversivo, este deliquente e perigoso; enfim cada um me clasificará de modo mais conforme as suas idéias, e todos se enganarão. Crer que existe um ente racional que não sinta o peso da escravidão, que não veja a cada passo o látego do dono levantado e que não conte diariamente os fuzis da cadeia que suporta, querer que o coração do escravo não sinta o injusto do cativeiro, que seus olhos não vejam a diferença que existe, entre seres da mesma espécie, uns que gozam, e outros que constantemente sofrem; é na verdade o cúmulo do delírio, da mais crassa insensatez. Disse-mo-lo porque eles o sabem e sentem mais que nós, porque pensamos unicamente; e tanto que eles experimentam todo o peso desta verdade; e quando nos empenhamos em demonstrá-las não é para exercitar a prática quase impossível por muitos anos de semelhantes doutrinas, mas sim para fazer sentir quão contraditório é em moral” (p. 53).
} 
que estamos tão distantes de podermos imitar as belas teorias de outros Povos, quanto distão os nossos elementos sociais de uma perfeita homogeneidade" (p. 51).

José Bonifácio perseguia uma homogeneidade; Abreu e Lima julga ser impossível, nas condições presentes, superar a heterogeneidade que distinguia a população imperial. Posições distintas que derivavam da avaliação a respeito do momento e do modo de ser abolida a escravatura. Como José Bonifácio, o autor de Bosquejo também sublinha a ausência de um "verdadeiro caráter nacional, o qual consiste na uniformidade de interesses e na homogeneidade de todos os caracteres individuais" (p. 73), o que resultava do fato de aquela "população" ser constituída por "cinco famílias" - negros livres, mulatos livres, brancos natos, brancos adotivos e escravos - inimigas e rivais entre si: "que somos todos inimigos e rivais uns dos outros na proporção das nossas respectivas classes, não necessitamos de argumentos para prová-lo, basta só que cada um dos que lerem este papel, seja qual for sua condição, meta a mão na sua consciência, e consulte os sentimentos do seu próprio coração" (p. 56). ${ }^{76}$

Divergindo a respeito da possibilidade da extinção da escravidão, ambos pareciam convergir a respeito do único elemento que poderia impedir a anarquia política, da qual fatalmente decorreria a fragmentação territorial. Nas palavras do Bosquejo, só a solução monárquica pode ser aplicada "com feliz sucesso para chamar a um centro comum os elementos de um povo heterogêneo"; também ali, as diferenças da população do Império exigiam uma "concentração mais vigorosa, que não pode dar-se sem incorrer na perda de liberdade senão em uma Monarquia Constitucional”. Ambos aparecem, então, como intransigentes defensores da Monarquia constitucional. Mas a fonte inspiradora da solução proposta por Abreu e Lima parece ser radicalmente diversa daquela de José Bonifácio; é a experiência bolivariana que o orienta também nesta oportunidade. Certamente, como destaca

\footnotetext{
76 “Todos os povos que foram colônias com respeito aos que foram metrópole, são hostis aos adotivos - "uns porque não permitem superiores, os outros porque não consentem iguais. A mesma razão se dá com respeito aos mulatos; nós não admitimos a igualdade, por efeito de hábitos arraigados, talvez por nossa má educação, eles não toleram superioridade, porque são homens como nós, nascidos no mesmo solo, e filhos de nossos próprios pais; embora a lei os nivele e assemelhe, o hábito e as preocupações inutilizam seus efeitos. Os negros ainda se acham em maior distância pela sua condição, pela idéia de que ainda se ressentem da escravidão, que suportaram eles mesmos ou seus progenitores; mas esta injusta opinião não basta para amortiguar no coração do negro a dignidade do seu ser, considerado como indivíduo da espécie humana. São injustas na verdade todas estas preocupações, são irritantes todas essas rivalidades; porém elas existem e contra fatos não pode haver argumentos". (p. 56)
} 
com pertinência Evaldo Cabral de Mello, não o Simón Bolívar da experiência federalista da primeira república venezuelana e da "Pátria boba" colombiana, mas o Bolívar da Constituição de Cúcuta de 1821, de feitio marcadamente unitário, inspirado nas constituições francesas de 1799 e 1802 (Cf. MELLO, 1986, p. 216; CASTRO, 1989).

Mas se Abreu e Lima parece dialogar com o velho Andrada por meio das páginas do Bosquejo, o principal diálogo ali travado era efetivamente com os contemporâneos, com aqueles que se apresentavam por meio de projetos distintos e opostos ao seu no transcurso da experiência regencial. ${ }^{77} \mathrm{Um}$ diálogo que, oito anos depois, saltaria das páginas de Bosquejo para as de Compêndio, em busca de novos interlocutores - a "mocidade Brasileira". Em seu novo fórum, aquele diálogo - então orientado por intenções diferentes daquelas do Bosquejo, - transformaria o narrador em personagem de sua narrativa a partir de determinado momento: a época moderna da História do Brasil, ou seja, nos capítulos que formam o segundo tomo de Compêndio. Ali, particularmente no último capítulo, a uma alegada e até certo ponto verdadeira escassez ou ausência de narrativas históricas disponíveis para serem compendiadas, o autor responde com um texto inteiramente seu. Ali, a narrativa da época que se estende de 1831 a 1841 - iniciada verdadeiramente no último parágrafo do capítulo anterior, onde é esboçado o perfil do primeiro imperador, e se encerra com as expectativas a respeito do reinado do "Segundo Pedro" - é tecida tanto com os fios da memória quanto com os de um projeto longamente acalentado, culminando em um prognóstico: "Quais serão os futuros do Brasil? Se mau fado não nos persegue mais, como até aqui, podem anunciar-se como muito lisonjeiros debaixo do reinado do Segundo Pedro". ${ }^{78}$ Servindo de guarda a um testemunho elevado à condição de um presságio positivo, as figuras dos imperadores logo se transformariam nas estampas que serviriam de guarda aos dois tomos de uma obra que, ao pôr em destaque o valor da Monarquia constitucional, assegurava aos brasileiros a consolidação de sua emancipação - poderia dizer -, "desde aqui...”.

\footnotetext{
77 "Agora, perguntamos: e um Povo que funda a sua existência sobre base tão incerta de direito e de justiça, pode sem temor de precipitar-se em um abismo, invocar em seu auxílio as teorias de outros Povos mais felizes e dotados de melhores elementos? E acaso em um país, onde os cidadãos resistem a todos os meios legais de destruir o flagelo da escravidão, onde as leis são ineficazes para minorar o mal que nos aflige, onde tudo conspira a perpetuar a miséria de nossa posição social, que inculcam princípios de uma liberdade sem freio, de uma licença popular, de um perfeita democracia? Não, não cremos, que possa haver boa fé em quem alimenta semelhantes pretensões" (p. 54-55). Ou ainda: "Qualquer execução desta garantia em um governo popular, transtorna a marcha dos acontecimentos e reduz a Nação a um governo oligárquico ou aristocrático que são duas formas odiosas, em que uma parte da sociedade oprime outras partes."

${ }^{78}$ Cf. a respeito da concepção moderna de História como um prognóstico, Koselleck (1993).
} 
A seus leitores Compêndio sugere, assim, uma espécie de dupla filiação. A primeira fora exposta nas páginas da "Introdução", e buscava demonstrar para os brasileiros o lugar que ocupavam no conjunto das "Nações civilizadas", ao pôr em evidência a "tese do suave comércio", nos termos de A. Hirschman. Por certo, tal civilização era devida também à ação dos religiosos, em particular aos jesuítas, e ao próprio papel desempenhado pela agricultura. ${ }^{79}$ Mas se o comércio ganha um valor explicativo essencial, nas páginas de Compêndio e nas de quase todos os autores da época e mesmo de períodos posteriores, é porque ele cumpre também o papel de nos unir àquelas nações da parte norte do hemisfério ocidental que, por sua vez, caminhavam elas também de modo acelerado no rumo da civilização e do progresso.

A segunda das filiações remete à possibilidade de uma emancipação: a emancipação dos brasileiros. Se D. Pedro I a efetivou, o governo do "Segundo Pedro" é a possibilidade de sua consolidação (de modo a sublinhar o tempo dessa possibilidade encerrei o antepenúltimo parágrafo com um “desde aqui...”). Contudo, o que é preciso considerar é que ela já se apresentara, na narrativa de Compêndio, a partir de um determinado momento, o qual o autor indica por meio de uma expressão: “Até aqui...”. Retorno, assim, às “Invasões Holandesas”.

Em termos temáticos, elas são o tema que ocupa o maior número de páginas em todo o Compêndio, desdobrando-se por duas "épocas": a terceira, 1580 e 1640, quando o Brasil esteve sob "o domínio da Espanha", e a quarta, 1641-1654, quando "o Brasil entra de novo no domínio português". O fato de os habitantes do Brasil terem estado sujeitos a domínios diversos, aliado às condições de luta de resistência ao invasor batavo terem sido completamente diferentes em cada uma delas, a par de outros acontecimentos ocorridos fora das áreas conquistadas pelos holandeses, permitiria a Abreu e Lima atribuir "cores" distintas a cada uma daquelas épocas. O destaque, porém, caberia à última delas: em seu transcurso, os

\footnotetext{
${ }^{79}$ A respeito do valor da agricultura, vejam-se os dois trechos, entre outros.: "O acontecimento de Minas (1789) em nada tinha alterado a tranquilidade da repartição do Sul, de sorte que o aumento progressivo da população e do comércio foi espantoso nos últimos anos do século XVIII. Ainda quando as minas não fossem já tão produtivas, como em suas primeiras lavras, contudo a agricultura tinha suprido a falta dos seus produtos, com a vantagem do acréscimo de indústria e da mudança de costumes bárbaros para outros mais suaves, consequência da estabilidade dos povos agrícolas, entre os quais a família é a primeira necessidade." "Qualquer execução desta garantia em um governo popular, trantorna a marcha dos acontecimentos e reduz a Nação a um governo oligárquico ou aristocrático que são duas forma odiosas, em que uma parte da sociedade oprime outras partes" $(\mathrm{V}, 250)$. E "A agricultura a que os palmarienses se entregaram com uma ordem e previdência que fazem pasmar, adoçou seus costumes" (V, 218).
} 
"Independentes de Pernambuco" fizeram sua aparição, projetando a figura de João Fernandes Vieira. O triunfo de Vieira no Monte das Tabocas, "fazia antever o triunfo da causa brasileira" (IV, 169, nota). E acrescenta, a respeito de acontecimento posterior no qual também tivera papel decisivo um dos “colonos portugueses", o mulato João Fernandes Vieira: "tal era o mais formidável inimigo dos holandeses; tal era o mais denodado campeão da independência de Pernambuco" (IV, 179 nota). Uma época que culminaria com o "triunfo dos Pernambucanos" (IV, 181).

Todavia, nas páginas de Compêndio, a luta contra o invasor batavo - que ali não recebe a denominação de "Insurreição Pernambucana" - projetaria outras figuras, como o "chefe brasileiro Filipe Camarão" - "este chefe hábil" (III, 131) de origem nativa; o negro Henrique Dias - "ainda que negro pelo nascimento não deixou de obter pela fama eterna memória, porque esta não atende ao acidente da cor, senão às qualidades do coração" (III, 143 nota); e ainda André Vidal de Negreiros - "filho da Paraíba [...] oficial sagaz, hábil e experimentado" (IV, 164 nota). Aos dois primeiros, a Camarão e a Henrique Dias, Abreu e Lima atribuiria valor destacado por meio das estampas que lhes dedicou, assim como das notas que esculpiam suas figuras. Quatro personagens que teriam tornado possível a expulsão do invasor e o triunfo da "guerra de independência"; ${ }^{80}$ quatro figuras - Vieira, Camarão, Henrique Dias e André Vidal de Negreiros - que, naquelas páginas, compunham um panteão pernambucano, ajudando a forjar uma memória que alimentava o "nativismo pernambucano", em especial aquele de cariz democrático e federalista, o que não podia ser bem recebido pelos dirigentes imperiais situados na Corte. ${ }^{81}$ Sempre presente de modo marcante em seu texto, ainda que na maior parte das vezes por meio das notas que o enriqueciam, o autor de Compêndio censuraria duramente a decisão dos governantes imperiais de extinguir os terços de homens pretos, constitídos por ocasião da luta contra os holandeses, e chefiados por Henrique Dias, e que depois passaram a Regimentos, ficando conhecidos como "Regimento dos Henriques". "Destruí-los, como fizemos, foi lançar por terra o único monumento que

\footnotetext{
${ }^{80}$ Em Rubro Veio, Evaldo Cabral de Mello ao chamar a atenção para o fato de Memórias históricas da Província de Pernambuco, de Fernandes Gama, reforçar o sentimento nativista radical, sublinha que, como Abreu e Lima, aquele historiador "refere-se, aliás, à restauração como 'guerra de independência' e aos chefes e tropas locais como os 'independentes', designaç̃̃es que serão adotadas tanto por Varnhagen quanto por D. Pedro II nas suas notas de viagem a Pernambuco" (MELLO, 1986, p. 141). Observo que a obra de Gama é posterior a Compêndio.

${ }^{81}$ A respeito do nativismo pernambucano, em suas diferentes manifestações, consultar, ainda nesta oportunidade, Mello (1986).
} 
restava das nossas glórias passadas; esquecidos talvez que esta classe de homens tinha em todas as épocas prestado grandes serviços à Monarquia, e ultimamente à nossa independência" (III, 143 nota). Como sempre, Abreu e Lima tinha os olhos no presente, enxergando naquela medida, além da construção de uma amnésia, o esvaziamento do poder provincial. Outra não era a postura dos dirigentes imperiais, que leriam o texto de Compêndio, particularmente as páginas dedicadas às guerras flamengas, com os olhos também postos no presente.

Também aqui, e talvez aqui, sobretudo, Compêndio estava no centro de uma luta de representações. Para os dirigentes imperiais empenhados em uma expansão para dentro, não se tratava tanto de "desmontar" ou "desfazer" o panteão pernambucano que, se não fora erigido naquelas páginas, ali encontrava um incentivo incomum; para aqueles dirigentes tratava-se de atribuir-lhe um sentido e um valor diversos, assim como ao acontecimento "Invasões Holandesas" como um todo; tratava-se, antes de tudo, em transformar o "triunfo dos Pernambucanos" em um acontecimento paradigmático da formação da nacionalidade brasileira, incorporando em um plano mais elevado a identidade local ou provincial - uma identidade colonial, disse acima - a uma identidade nacional. ${ }^{82}$ Também aqui a comparação entre o texto de Compêndio e aqueles outros mais afinados às proposições do I.H.G.B., como a História Geral do Brasil de F. A. de Varnhagen, mostra-se ilustrativa.

Fazendo uma espécie de balanço dos resultados da guerra, Abreu e Lima afirmava:

Se a invasão dos holandeses prejudicou a Portugal e ao Brasil pelas devastações, que se seguiram em conseqüência de uma guerra quase de extermínio, é igualmente incontestável que eles, transportando às possessões de Ultramar a ordem e atividade que os distinguia na Europa, muito concorreram para o aumento e a civilização deste país. Muitos vestígios de sua indústria atestam ainda hoje no Brasil a verdade desta asserção, e por

\footnotetext{
${ }^{82}$ Por ter em consideração a circunstância de o perfil daqueles personagens paradigmáticos ter sido traçado por Abreu e Lima principalmente nas notas, valeria a pena analisar até que ponto a retirada das notas nas edições subseqüentes, combinando-se ao fato de as estampas também não mais terem sido reproduzidas, contribuiu para uma aceitação mais favorável de Compêndio.
} 
muito tempo as observações de Pison e de Marcgraff foram as únicas que podiam servir de guias na História Natural destas regiões" (IV, 200). ${ }^{83}$

Varnhagen, por certo, não ignorava aquelas contribuições, mas dos resultados da guerra o que lhe importava sublinhar era o seu caráter civilizador: "um axioma comprovado pela história que, às vezes, estas [as guerras] são civilizadoras, e que trazem energia e atividade a povos entorpecidos pela inércia, a preguiça e o ilhamento". (apud MATTOS, 2002b). De acordo com Varnhagen, as guerras flamengas tinham possibilitado a aproximação entre as capitanias até então dispersas, permitindo "a tolerância dos povos de uma capitania para as outras... de modo que quase se pode assegurar que dessa guerra data o espírito público mais generalizado por todo o Brasil"; elas tinham propiciado também um maior e melhor conhecimento do Brasil na Europa, graças, sobretudo, ao padre Vieira, agente diplomático de D. João IV na Holanda; e elas teriam possibilitado ainda a aproximação entre os diferentes grupos étnicos da colônia portuguesa na América, contribuindo para a formação do povo brasileiro, de uma maneira muito próxima às proposições de Martius.

Assim, na Memória que apresentara ao I.H.G.B., Martius destacara que

qualquer que se encarregar de escrever a História do Brasil, país que tanto promete, jamais deverá perder de vista quais os elementos que aí concorreram para o desenvolvimento do homem. São porém estes elementos de natureza muito diversa, tendo para a formação do homem convergido de modo particular três raças, a saber: a de cor de cobre ou americana, a branca ou caucasiana, e enfim a preta ou etiópica. Do encontro, da mescla, das relações mútuas e mudanças dessas três raças formou-se a atual população, cuja história por isso mesmo tem um cunho muito particular. [...] Jamais nos será permitido duvidar que a vontade da providência predestinou ao Brasil esta mescla. $\mathrm{O}$ sangue português em um poderoso rio deverá absorver os pequenos confluentes das raças índia e etiópica.

\footnotetext{
${ }^{83}$ Reafirmando sua adesão ao "nativismo pernambucano", dissera em outra ocasião a respeito da herança portuguesa: "A descendência portuguesa é a causa de ser o [brasileiro] mais atrasado e mais ignorante povo do continente americano" (ABREU E LIMA, 1835, p. 73).
} 
A explicação da formação da população brasileira, "cuja história [...] tem um cunho muito particular", estava dada, sublinhando o encontro, a mescla, as relações mútuas e mudanças das três raças, sob a égide do "sangue português". Naquela explicação, o elemento branco encontrava o seu lugar privilegiado, como um poderoso rio que absorveria os pequenos confluentes; nela, a boa sociedade, constituída por aqueles que eram livres e se auto-representavam como brancos, distinguia-se dos demais segmentos e "nações" constitutivos da sociedade imperial e da população do Império, respectivamente; e nela a escravidão, embora repudiada, cumpria um papel hierarquizante que reforçava valores como honra, prestígio, caridade e outros intimamente associados a um sentimento aristocrático. Nesta oportunidade, talvez seja interessante lembrar que a "Memória" seria vencedora do concurso instituído pelo I.H.G.B. não tanto porque Martius dizia o que os sócios da instituição queriam ouvir a respeito das imagens que elaboravam a respeito dos brasileiros, da sociedade imperial e do Estado imperial; e sim porque, certamente, Martius escrevia o que aqueles sócios há muito queriam dizer, não encontrando o modo de fazê-lo por meio da escritura da História do Brasil.

Diversa, quase oposta, era a proposição de Abreu e Lima. Ao texto de Compêndio é completamente estranha a idéia ou imagem da formação da população brasileira (ou do povo brasileiro) a partir da mescla ou miscigenação de três "raças" ou grupos étnicos, na qual a prevalência do "sangue português" provocava o desaparecimento dos "pequenos confluentes das raças índia e etiópica”. Por considerar inevitável a permanência da escravidão ainda por um longo tempo, embora a ela se oponha contundentemente, Abreu e Lima sublinha a heterogeneidade da população brasileira, pondo em destaque as diferenças quer entre "pernambucanos", "baianos", "mineiros"..., quer entre "brancos natos", "brancos adotivos", "negros livres", "mulatos livres" e "escravos". Se este conjunto diferenciado, contido em um território mas sempre tendendo a uma fragmentação parecia por vezes constituir uma unidade homogênea, e assim efetivamente acontecia, tal ocorria em situações específicas, como a da Independência, porque ali, como sujeitos políticos, os brasileiros deviam qual um conjunto se opor a uma dominação, seguindo a orientação daqueles que propugnavam a emancipação: 
Foi a 7 de Setembro de 1822, sobre as margens do Ipiranga, riacho da vizinhança de S. Paulo, que o Príncipe anuiu finalmente aos desejos dos Brasileiros mais ilustrados; e este dia marca a era da Independência do Brasil. (VII, 20)

A mensagem era clara: o Príncipe, por meio de uma ação que propiciava uma emancipação, transformava os brasileiros em um todo compacto; e ao mesmo transformava-se em Imperador.

Uma heteregoneidade que, já o vimos, preexistia à própria constituição da nação. Mas uma heterogeneidade que não podia prescindir de uma autoridade tutelar, que lhe garantisse coesão e permanência, expressada sob a forma da Monarquia constitucional. Das páginas de Compêndio não se depreende, ao final, outra intenção de seu autor: demonstrar à "mocidade Brasileira" que o existir dos "Brasileiros" se associa íntima e inevitavelmente ao existir de seu Soberano constitucional.

\section{VICISSITUDES}

Em 1854 - onze anos após a publicação de Compêndio -, Joaquim Manuel de Macedo agradecia, em sessão do IHGB, a oferta à instituição do tomo primeiro da História Geral do Brasil de Francisco Adolfo de Varnhagen. Destacava, então, o trabalho criterioso com as fontes históricas e o método escolhido. Na mesma ocasião, observava não existirem ainda compêndios que "contentassem as exigências da civilização." ${ }^{84}$ Difícil dizer se aos que o ouviam teria causado estranheza a observação de Macedo, ou se por ela esperavam. A nós, porém, ela soa estranha, por vários motivos.

Havia 23 anos que o Resumo de História do Brasil, de Henrique Luis de Niemeyer Bellegard, era utilizado para o ensino da História Pátria, tendo recebido a aprovação do IHGB, logo após sua fundação. A obra era a tradução do livro homônimo de Ferdinand Denis,

\footnotetext{
${ }^{84}$ Revista do IHGB. Tomo XVII, 1854, p.108.
} 
publicado em Paris, em 1826. Bellegarde adicionara ao texto de Denis contribuições feitas a partir de outros autores, de modo a informar a respeito da "primeira época", ou seja, aquela referente aos aborígenes, inexistente no livro que traduzira. Ora, Macedo não devia ignorar que, a partir de 1841, Resumo fora adotado no Imperial Colégio de Dom Pedro II nas aulas dedicadas ao estudo da história pátria.

Recordo ainda que o próprio Abreu e Lima dele se valera para escrever o capítulo primeiro de Compêndio, e que, em 1844, uma Comissão do IHGB o considerara mais recomendável para a instrução elementar que o próprio Compêndio.

Quando, no início de 1849, foi criada a cadeira de História do Brasil naquele estabelecimento modelar, Gonçalves Dias, professor de Latim, foi o escolhido para ministrar as duas aulas semanais da disciplina (DORIA, 1997, p. 69). O poeta-professor, ou o professorpoeta, não se mostrou inclinado a adotar Resumo, embora a obra tivesse sido recomendada, em diferentes ocasiões, por Januário da Cunha Barbosa, o poderoso Secretário do IHGB, e já fosse utilizada por muitos dos que freqüentavam os bancos do colégio. Mostrando-se insatisfeito com o estado da matéria, ele prefiriu consultar a obra de Southey, conforme se depreende de um Aviso do Ministro do Império à Reitoria do Colégio:

Aviso do Ministro Monte Alegre à Reitoria do Colégio:

Rio de Janeiro - Ministério dos Negócios do Império em 27 de abril de 1849.

Participando o ajudante de Bibliotecário da Biblioteca Pública desta Corte que existe em poder do professor da $1^{\text {a }}$ cadeira de História e Geografia desse Colégio, João Baptista Calógeras, a História de Southey que o professor da $2^{\text {a }}$ cadeira de latim do mesmo Colégio, o bacharel Antônio Gonçalves Dias, deseja consultar para o desempenho de trabalhos que tem a seu cargo: Há Sua Majestade o Imperador por bem que a referida História de Southey seja entregue ao referido bacharel Gonçalves Dias debaixo de sua responsabilidade. $\mathrm{O}$ que comunica a $\mathrm{V}$. Mcê. para seu conhecimento e execução

Deus guarde a V. Mcê

Visconde de Monte Alegre 
No entanto, pouco tempo depois, em fevereiro de 1851, Gonçaves Dias afastar-se-ia de suas atribuições no Colégio; deveria partir, como de fato aconteceu logo a seguir, em missão oficial para as "províncias do Norte". Então, duas tarefas lhe foram confiadas: recolher documentos nos arquivos e bibliotecas de mosteiros e nas repartições públicas, enviando-os, em seguida, para o Arquivo Público do Império, e visitar os diversos estabelecimentos de ensino com o objetivo de verificar o estado da instrução pública em cada uma das províncias.

Ainda durante o breve exercício de Gonçalves Dias na nova cadeira, Joaquim Manuel de Macedo fora nomeado para reger a primeira cadeira de Geografia e História do Brasil, no final do ano anterior. ${ }^{85}$ Tudo leva a crer que Macedo teria adotado o Compêndio da História do Brasil de Abreu e Lima para as suas aulas. De acordo com os "Programas de Ensino" da nova cadeira, existentes no NUDOM, Compêndio foi adotado no Colégio de 1850 até o ano de 1862, quando foi substituído por Lições de História do Brasil, cujo primeiro tomo era dirigido aos estudantes do $4^{\circ}$ ano.

Assim, a observação do autor de A Moreninha, por ocasião do recebimento da monumental História Geral do Brasil de Varnhagen, revela, entre outras coisas, que mesmo tendo sido adotado no Colégio de Pedro II e recomendado pelo IHGB, o Resumo de autoria de Bellegard não merecia ser nomeado e, ainda mais significativo, continuavam a prevalecer a censura e o silêncio - uma quase condenação - a Compêndio, na instituição que se atribuía a incumbência e exclusividade de escrever a História do Brasil e velar por sua divulgação por meio da instrução pública. No entanto, na mais importante instituição de instrução pública do Império, Compêndio havia mais de três anos fora escolhido para instruir os jovens alunos, não obstante as críticas e censuras que recebera desde sua publicação.

Posição interessante a adotada por Macedo, porque ambigüa. Em sua atividade como professor, via na obra de Abreu e Lima qualidades que justificavam a sua utilização em sala

\footnotetext{
${ }^{85}$ Cf. a respeito: "Professores Catedráticos e efetivos" in Anuário do Colégio Pedro II, vol. XV, 1949 - 1950. RJ: República dos Estados Unidos do Brasil - MEC, 1954, p. 405/406.
} 
de aula; como conceituado sócio do IHGB, ao não mencioná-la, fazendo coro com uma interdição, negava-lhe as mesmas qualidades.

Uma posição ambígua, contraditória mesmo, e aí reside talvez a importância de considerá-la mais de perto. Caso comparemos o plano das duas obras que pareciam rivalizar entre si, e efetivamente rivalizavam, vários pontos se destacam, em especial uma semelhança que permite afirmar que, desde o momento da criação do IHGB, talvez mesmo desde antes, uma determinada forma de narrar o que se entendia por uma História do Brasil vinha se afirmando. Dela, o elemento ordenador principal é o Estado nacional, conforme o revela fortemente a proposição da divisão em duas "épocas": "antiga" e "moderna". Nela, todavia, o Estado nacional muitas vezes parece não ocupar o lugar principal. Mas nela ainda o valor atribuído ao território explica o destaque dado à sua defesa e preservação, quer em face das “invasões estrangeiras”, quer das diferentes rebeliões e revoltas, revoluções e demais comoções internas.

O quadro é extenso, mas vale a pena considerá-lo com atenção.

\section{QUADRO V}

\begin{tabular}{|c|c|c|}
\hline $\begin{array}{l}\text { COMPÊNDIO DA HISTÓRIA DO } \\
\text { BRASIL }\end{array}$ & \multicolumn{2}{|c|}{$\begin{array}{c}\text { LIÇÕES DE HISTÓRIA DO BRASIL para uso dos } \\
\text { alunos do Imperial Colégio Pedro II }\end{array}$} \\
\hline Prefácio & \multicolumn{2}{|c|}{$1^{\circ}$ Tomo - Para alunos do $4^{\circ}$ ano - Prefácio. } \\
\hline Introducão & Licão I & Consideraccões Preliminares. \\
\hline CAPÍTULO PRIMEIRO 1500 - 1531 & Lição & Descobrimento do Brasil. \\
\hline $\begin{array}{l}\text { I. Descobrimento do Brasil por Pedro } \\
\text { Álvares Cabral. }\end{array}$ & & \\
\hline $\begin{array}{l}\text { II. Primeiras explorações das terras do } \\
\text { Brasil. }\end{array}$ & $\begin{array}{l}\text { Lição } \\
\text { III }\end{array}$ & Primeiras Explorações. \\
\hline $\begin{array}{l}\text { III. Martim Afonso de Souza navega por } \\
\text { toda a costa desde o Cabo de Santo } \\
\text { Agostinho até o Rio da Prata, e volta a } \\
\text { fundar a Colônia de S. Vicente. Duarte } \\
\text { Coelho Pereira expulsa os Franceses de } \\
\text { Itamaracá. }\end{array}$ & $\begin{array}{l}\text { Lição } \\
\text { IV }\end{array}$ & $\begin{array}{l}\text { Cristóvão Jacques e Martim Afonso de } \\
\text { Souza. }\end{array}$ \\
\hline IV. Descripção geral desta vasta região. & $\begin{array}{l}\text { Lição } \\
\text { V }\end{array}$ & $\begin{array}{l}\text { O Brasil em geral - Povos que o habitaram na } \\
\text { época do seu descobrimento. } \\
\text { Do gentio do Brasil em geral. } \\
\text { Do gentio do Brasil em relação à família. } \\
\text { O gentio do Brasil em suas relações sociais. }\end{array}$ \\
\hline $\begin{array}{l}\text { V. Caracter, usos e costumes dos habitantes } \\
\text { naturais do Brasil. }\end{array}$ & $\begin{array}{l}\text { Lição } \\
\text { VI }\end{array}$ & $\begin{array}{l}\text { O Sistema de Colonização do Brasil } \\
\text { empregado por D. João III (1534-1549). }\end{array}$ \\
\hline
\end{tabular}




\begin{tabular}{|c|c|c|}
\hline $\begin{array}{l}\text { CAPÍTULO SEGUNDO } \mathbf{1 5 3 2}-\mathbf{1 5 8 0} \\
\text { I. Capitanias hereditárias estabelecidas no } \\
\text { Brasil no reinado d'El-Rei D. João III. }\end{array}$ & $\begin{array}{l}\text { Lição } \\
\text { VII }\end{array}$ & $\begin{array}{l}\text { Primeiros Donatários } \\
\text { Hereditárias no Brasil. }\end{array}$ \\
\hline $\begin{array}{l}\text { II. Estado das outras Capitanias. Chegada ao } \\
\text { Brasil de Tomé de Souza, primeiro } \\
\text { Governador Geral. }\end{array}$ & $\begin{array}{l}\text { Lição } \\
\text { VIII }\end{array}$ & $\begin{array}{l}\text { Estabelecimento de um Governo Geral no } \\
\text { Brasil: Tomé de Souza - Primeiro } \\
\text { Governador-Geral do Brasil. }\end{array}$ \\
\hline $\begin{array}{l}\text { III. Influência da Religião no Brasil. Estado } \\
\text { do Clero da Colônia. Segundo e terceiro } \\
\text { Governadores Geraes. }\end{array}$ & $\begin{array}{l}\text { Lição } \\
\text { IX }\end{array}$ & $\begin{array}{l}\text { Duarte da Costa. Segundo Governador-Geral } \\
\text { do Brasil. }\end{array}$ \\
\hline $\begin{array}{l}\text { IV. Tentativa dos Franceses para se } \\
\text { estabelecerem no Brasil. Expedição de } \\
\text { Nicolau Durand de Villegaignon. } \\
\text { Expulsão dos Franceses do Rio de } \\
\text { Janeiro. Fundação da Cidade de S. } \\
\text { Sebastião. }\end{array}$ & $\begin{array}{l}\text { Lição } \\
X\end{array}$ & $\begin{array}{l}\text { Men de Sá - Terceiro Governador-Geral do } \\
\text { Brasil. }\end{array}$ \\
\hline $\begin{array}{l}\text { V. Divisão do Brasil em dois Governos } \\
\text { distintos. } \\
\text { Tupinambás. O Bransmigração dosil de novo debaixo } \\
\text { de um só Governo. Acontecimentos que } \\
\text { fazem passar o Reino de Portugal e suas } \\
\text { Colônias para o domínio da Espanha. }\end{array}$ & $\begin{array}{l}\text { Lição } \\
\text { XI }\end{array}$ & $\begin{array}{l}\text { Divisão do Brasil em dois governos; } \\
\text { subseqüente reunião em um só. } \\
\text { Domínio Espanhol. }\end{array}$ \\
\hline CAPITULO TERCEIRO 1580 - 1640 & & $2^{\circ}$ Tomo - Para alunos do $7^{\circ}$ ano \\
\hline $\begin{array}{l}\text { I. Estado do Brasil na epocha em que passou } \\
\text { para o domínio da Espanha. Diversas } \\
\text { incursões dos piratas ingleses. Novas } \\
\text { indagações sobre as minas de prata do } \\
\text { Brasil. O fabuloso pais - El Dorado. }\end{array}$ & Lição I & $\begin{array}{l}\text { Domínio da Espanha considerações gerais. } \\
\text { Estado em que se achava o Brasil em } 1581 \text {. }\end{array}$ \\
\hline $\begin{array}{l}\text { II. Administração de Pedro Botelho. Aliança } \\
\text { dos Aimorés. D. Diogo de Menezes. } \\
\text { Fundação do Ceará. Estabelecimento dos } \\
\text { Franceses no Maranhão. Gaspar de } \\
\text { Souza. }\end{array}$ & $\begin{array}{l}\text { Lição } \\
\text { II }\end{array}$ & $\begin{array}{l}\text { Governo-geral de Manuel Telles Barreto. } \\
\text { Dois governos provisórios, um precedendo e } \\
\text { outro sucedendo aquele: } 1581-1591 .\end{array}$ \\
\hline $\begin{array}{l}\text { III. Expedição de Jerônimo de Albuquerque } \\
\text { e de Alexandre de Moura. Expulsão dos } \\
\text { Franceses da ilha e costa do Maranhão. } \\
\text { Conquista do Grão-Pará, e fundação da } \\
\text { Cidade de Belém. Criação do novo } \\
\text { Estado do Maranhão. }\end{array}$ & $\begin{array}{l}\text { Lição } \\
\text { III }\end{array}$ & $\begin{array}{l}\text { D. Francisco de Souza e Diogo Botelho, } \\
\text { sétimo e oitavo governadores-gerais do Brasil } \\
\text { 1581-1607. }\end{array}$ \\
\hline $\begin{array}{l}\text { IV. Os Holandeses invadem o } \text { Brasil. } \\
\text { Occupação da Cidade de S. Salvador. } \\
\text { Expulsão dos Holandeses. } \\
\text { parciais. Crueldade cometida } \\
\text { Indiontra os } \\
\text { Îndios. }\end{array}$ & $\begin{array}{l}\text { Lição } \\
\text { IV }\end{array}$ & $\begin{array}{l}\text { Nova divisão do Brasil em dois governos } \\
\text { subsequiente reunião em um só - Franceses no } \\
\text { Maranhão. }\end{array}$ \\
\hline $\begin{array}{l}\text { V. Segunda expedição holandesa contra o } \\
\text { Brasil. Ocupação de Olinda e do Recife. } \\
\text { Campo Real do Bom Jesus. Surpresa do } \\
\text { Gereral Loncq. Ataque de Olinda pelos } \\
\text { Portugueses. }\end{array}$ & $\begin{array}{l}\text { Lição } \\
\text { V }\end{array}$ & $\begin{array}{l}\text { Primeira invasão dos holandeses. Perda e } \\
\text { restauração da cidade de Salvador - 1624- } \\
1625 \text {. }\end{array}$ \\
\hline
\end{tabular}




\begin{tabular}{|c|c|c|}
\hline $\begin{array}{l}\text { VI. A guerra muda de aspecto. Combate } \\
\text { naval. Incêndio de Olinda. Calabar } \\
\text { abandona os Portugueses. Consequiências } \\
\text { funestas da sua traição. Morte do General } \\
\text { holandes Reimbach. Rasgo patriótico de } \\
\text { Jaguarary. Os Palmares. Conquista da } \\
\text { Paraíba pelos holandeses. Ocupação do } \\
\text { Pontal de Nazareth. }\end{array}$ & $\begin{array}{l}\text { Lição } \\
\text { VI }\end{array}$ & $\begin{array}{l}\text { Segunda invasão: perda de Olinda e do } \\
\text { Recife, e subseqüente guerra até a retirada de } \\
\text { Matias de Albuquerque - 1630-1635. }\end{array}$ \\
\hline $\begin{array}{l}\text { VII. Últimos esforços dos Portugueses em } \\
\text { Pernambuco. Emigração e abandono da } \\
\text { Província. Ocupação de Porto calvo. } \\
\text { Suplício de Calabar. Albuquerque é } \\
\text { chamado à Europa. Rebello, Camarão e } \\
\text { Henrique Dias. Segunda emigração de } \\
\text { Pernambuco. Mauricio de Nassau. } \\
\text { Derrota dos Portugueses em Porto Calvo. } \\
\text { Fuga de Bagnuolo. Segunda invasão da } \\
\text { Bahia. Retirada de Nassau. Outras } \\
\text { conquistas dos Holandeses. }\end{array}$ & $\begin{array}{l}\text { Lição } \\
\text { VII }\end{array}$ & $\begin{array}{l}\text { Guerra Holandesa: desde a retirada de Matias } \\
\text { de Albuquerque até a aclamação de D. João } \\
\text { IV no Brasil 1635-1641. }\end{array}$ \\
\hline $\begin{array}{l}\text { VIII. Estado político das Províncias do } \\
\text { Maranhão. Viagem de Teixeira pelo } \\
\text { Amazonas até Quito. Sua volta a Belém. } \\
\text { O Conde da Torre. O Marquês de } \\
\text { Montalvão, primeiro Vice-Rei nomeado } \\
\text { para o Brasil. Revolução de Portugal. }\end{array}$ & $\begin{array}{l}\text { Lição } \\
\text { VIII }\end{array}$ & $\begin{array}{l}\text { O Estado do Maranhão e as diversas } \\
\text { Capitanias da Bahia para o sul, desde a } \\
\text { primeira invasão dos holandeses até a Época } \\
\text { da Regeneração de Portugal 1624-1641. }\end{array}$ \\
\hline $\begin{array}{l}\text { CAPITULO QUARTO 1641 - } \mathbf{1 6 5 4} \\
\text { I. O Brasil entra de novo no domínio } \\
\text { português. Mauricio de Nassau deixa o } \\
\text { governo da Colônia, e volta para a } \\
\text { Holanda. Decadência do Brasil holandes. } \\
\text { O Maranhão e o Ceará libertam-se dos } \\
\text { Holandeses. Conspiração de Pernambuco } \\
\text { descoberta. João Fernandes Vieira reúne } \\
\text { os seus amigos e toma as armas. }\end{array}$ & $\begin{array}{l}\text { Lição } \\
\text { IX }\end{array}$ & $\begin{array}{l}\text { Guerra Holandesa no Brasil desde a } \\
\text { aclamação de D. João IV até o rompimento } \\
\text { pernambucano 1641-1645. }\end{array}$ \\
\hline $\begin{array}{l}\text { II. Vieira é reconhecido Chefe dos } \\
\text { Independentes de Pernambuco. Combate } \\
\text { de Tabocas. Junção de Vidal, Moreno, } \\
\text { Henrique Dias, e Camarão com João } \\
\text { Fernandes Vieira. Combate naval de } \\
\text { Tamandaré. Ataque e tomada da casa } \\
\text { Forte por Vieira e Vidal. O General Huss } \\
\text { prisioneiro. }\end{array}$ & $\begin{array}{l}\text { Lição } \\
\text { X }\end{array}$ & $\begin{array}{l}\text { Último período da guerra holandesa desde o } \\
\text { rompimento da Insurreição pernambucana até } \\
\text { a capitulação da Taborda 1645-1654. }\end{array}$ \\
\hline $\begin{array}{l}\text { III. Compra da Fortaleza de Nazaré. Ataque } \\
\text { de Itamaracá. Traição dos trânsfugas } \\
\text { holandeses, Vieira queima as suas } \\
\text { próprias plantações. Conspiração contra } \\
\text { Vieira. Sua magnanimidade. O General } \\
\text { Sigismundo chega com uma frota } \\
\text { holandesa ao Recife. }\end{array}$ & $\begin{array}{l}\text { Lição } \\
\text { XI }\end{array}$ & $\begin{array}{l}\text { Paz de Portugal, com a Holanda. Causas da } \\
\text { ruína do poder holandês no Brasil, e do } \\
\text { triunfo dos pernambucanos. Resultados da } \\
\text { guerra } 1661 \text {. }\end{array}$ \\
\hline
\end{tabular}




\begin{tabular}{|c|c|c|}
\hline $\begin{array}{l}\text { IV. Proposição de anistia. Resposta de } \\
\text { Vieira. Sigismundo é batido e ferido. } \\
\text { Tomada da ilha de Itaparica. Morte de } \\
\text { Rebello. O Conde de Villapouca vem } \\
\text { render a Teles da Silva. Francisco Barreto } \\
\text { de Menezes toma o mando do exército de } \\
\text { Pernambuco. Batalha dos Guararapes. } \\
\text { Triunfo dos Pernambucanos. }\end{array}$ & $\begin{array}{l}\text { Lição } \\
\text { XII }\end{array}$ & $\begin{array}{l}\text { Erros administrativos no Brasil: motins } \\
\text { populares, descobrimentos, modificações e } \\
\text { desenvolvimento da administração civil e } \\
\text { eclesiástica - Luta entre os jesuítas e os } \\
\text { colonos - Compahia do Estanco no Maranhão } \\
\text { - revolta de Beckman 1652-1655. }\end{array}$ \\
\hline $\begin{array}{l}\text { V. Apoderam-se os Holandeses de Olinda. } \\
\text { Sortida do General Brinck. Sigismund } \\
\text { devasta de novo as costas da Bahia. } \\
\text { Morte de Camarão. Segunda batalha dos } \\
\text { Guararapes. Derrota e morte do General } \\
\text { Brinck. O Conde de Castelo - melhor } \\
\text { Vice-rei do Brasil. Continuação do cerco } \\
\text { do Recife. }\end{array}$ & $\begin{array}{l}\text { Lição } \\
\text { XIII }\end{array}$ & $\begin{array}{l}\text { Destruição de Palmares. Guerras Civis dos } \\
\text { mascates em Pernambuco, e dos emboabas } \\
\text { em Minas 1675-1714. }\end{array}$ \\
\hline $\begin{array}{l}\text { VI. A esquadra de Magalhães surge em } \\
\text { Nazaré. Conselho de guerra. Bloqueio do } \\
\text { Recife. Ataque das obras exteriores por } \\
\text { Vieira. Ataque das Cinco-Pontas. Motim } \\
\text { do povo e da guarnição do Recife. } \\
\text { Capitulação dos Holandeses. Todo o } \\
\text { Brasil entra no domínio da Coroa de } \\
\text { Portugal. }\end{array}$ & $\begin{array}{l}\text { Lição } \\
\text { XIV }\end{array}$ & $\begin{array}{l}\text { Efeitos da guerra de sucessão da Espanha no } \\
\text { Brasil. Lutas com os espanhóis ao sul: } \\
\text { hostilidade dos franceses comandados por } \\
\text { Duclerc e por Duguay-Trouin no Rio de } \\
\text { Janeiro. Tratados de Utrecht e de Madri 1678- } \\
1750 \text {. }\end{array}$ \\
\hline $\begin{array}{l}\text { CAPITULO QUINTO 1654- } \mathbf{1 8 0 7} \\
\text { I. Tratado de paz de } 1660 \text { entre Portugal e a } \\
\text { Holanda. O Príncipe D. Pedro, Regente } \\
\text { de Portugal. Tratado de paz de } 1668 \text { entre } \\
\text { Portugal e a Espanha. Estado do Brasil. } \\
\text { Os Paulistas ou Mamelucos do Brasil } \\
\text { durante o século XVII. }\end{array}$ & $\begin{array}{l}\text { Lição } \\
\text { XV }\end{array}$ & $\begin{array}{l}\text { Desenvolvimento e progresso do Brasil no } \\
\text { reinado de D. João V 1706-1750. }\end{array}$ \\
\hline $\begin{array}{l}\text { II. A Ilha de Santa Catarina. Povoação das } \\
\text { Alagoas. Fundação da Colônia do } \\
\text { Sacramento. Sabará e Villa Rica. Guerra } \\
\text { civil. Antonio d'Albuquerque, } \\
\text { Governador do Distrito das Minas. } \\
\text { Destruição completa dos Palmares. }\end{array}$ & $\begin{array}{l}\text { Lição } \\
\text { XVI }\end{array}$ & $\begin{array}{l}\text { Reinado de D. José I: questões e lutas no sul } \\
\text { do Brasil: Jesuítas e sua expulsão: o Marquês } \\
\text { de Pombal 1750-1777. }\end{array}$ \\
\hline $\begin{array}{l}\text { III. Bispados do Brasil. Expedição } \\
\text { malograda de Duclerc. Duguay-Trouin } \\
\text { toma a cidade do Rio de Janeiro, que foi } \\
\text { depois resgatada pelos seus habitantes. }\end{array}$ & $\begin{array}{l}\text { Lição } \\
\text { XVII }\end{array}$ & $\begin{array}{l}\text { Primeiras idéias de independência do Brasil: } \\
\text { conspiração malograda em Minas Gerais } \\
\text { 1786-1792. }\end{array}$ \\
\hline $\begin{array}{l}\text { IV. Tratado de Utrecht. A Cidade de } \\
\text { Mariana. Vila do Cuiabá. Vila Boa de } \\
\text { Goiás. Primeiro diamante achado no } \\
\text { Brasil. Tratado de 1750. O Marquês de } \\
\text { Pombal. Extinção dos Jesuítas. }\end{array}$ & $\begin{array}{l}\text { Lição } \\
\text { XVIII }\end{array}$ & $\begin{array}{l}\text { Transmigração da família real de Bragança } \\
\text { para o Brasil: sede da monarquia portuguesa } \\
\text { no Brasil 1807-1815. }\end{array}$ \\
\hline
\end{tabular}




\begin{tabular}{|c|c|c|}
\hline $\begin{array}{l}\text { V. Influência da administração de Pombal } \\
\text { sobre o Brasil. Guerras do Sul. Santa } \\
\text { Catarina e a Colônia do Sacramento caem } \\
\text { em poder dos Espanhóis. Dona Maria I. } \\
\text { Queda do Marquês de Pombal. Tratados } \\
\text { de } 1777 \text { e } 1778 \text {. O Arraial do Tejuco. } \\
\text { Grande diamante da Coroa de Portugal. }\end{array}$ & $\begin{array}{l}\text { Lição } \\
\text { XIX }\end{array}$ & $\begin{array}{l}\text { Guerras com os espanhóis ao sul e com os } \\
\text { franceses ao norte do Brasil. Revolução } \\
\text { republicana em Pernambuco. 1801-1821. }\end{array}$ \\
\hline $\begin{array}{l}\text { VI. Projeto de revolução em Minas. O } \\
\text { Príncipe D. João Regente de Portugal. } \\
\text { Estado do Brasil no fim do século XVIII. } \\
\text { Guerra de 1801. Transmigração da } \\
\text { Família Real de Bragança para o Brasil. }\end{array}$ & $\begin{array}{l}\text { Lição } \\
\text { XX }\end{array}$ & $\begin{array}{l}\text { Revolução de Portugal em 1820: seus efeitos } \\
\text { no Brasil - regresso da Corte Portuguesa para } \\
\text { Lisboa } 1820-1821 \text {. }\end{array}$ \\
\hline $\begin{array}{l}\text { CAPITULO SEXTO 1808- 1821 } \\
\text { I. A Família Real chega ao Brasil. } \\
\text { Entusiasmo geral. Os portos do Brasil } \\
\text { abrem-se a todas as nações amigas. } \\
\text { Novos e importantes estabelecimentos. } \\
\text { Tomada e occpação de Caiena. D. } \\
\text { Rodrigo de Souza Coutinho. Os } \\
\text { aventureiros que acompanharam a } \\
\text { Família Real. O Brasil elevado à } \\
\text { categoria de Reino. }\end{array}$ & $\begin{array}{l}\text { Lição } \\
\text { XXI }\end{array}$ & $\begin{array}{l}\text { Primeiros meses da Regência de D. Pedro no } \\
\text { Brasil } 1821 \text {. }\end{array}$ \\
\hline $\begin{array}{l}\text { II. Revolução e Independência de Buenos } \\
\text { Ayres. Exército de observação nas } \\
\text { fronteiras do Rio Grande. Campanhas de } \\
1811 \text { e 1812. Armistício. A divisão } \\
\text { portuguesa de voluntários d' El-Rei. } \\
\text { Campanhas de } 1816 \text { e 1817. Occupação } \\
\text { de Montevidéo e da Colônia do } \\
\text { Sacramento. }\end{array}$ & $\begin{array}{l}\text { Lição } \\
\text { XXII }\end{array}$ & Desde o dia do "Fico" até o dia do Ipiranga. \\
\hline $\begin{array}{l}\text { III. Morte da rainha. Revolução de } \\
\text { Pernambuco. Causas principais deste } \\
\text { acontecimento. Conselho de guerra. } \\
\text { Morte do Brigadeiro Manoel Joaquim } \\
\text { Barbosa de Castro. O Governador } \\
\text { capitula no Forte do Brum, e parte para o } \\
\text { Rio de Janeiro. Governo provisório. }\end{array}$ & $\begin{array}{l}\text { Lição } \\
\text { XXIII }\end{array}$ & $\begin{array}{l}\text { Aclamação e coroação do } 1^{\circ} \text { Imperador do } \\
\text { Brasil. Guerra de Independência - conclusão. }\end{array}$ \\
\hline $\begin{array}{l}\text { IV. A Paraíba e o Rio Grande do Norte. } \\
\text { Comissões ao Ceará e à Bahia. Funestos } \\
\text { resultados. Bloqueio de Pernambuco. O } \\
\text { Marechal Gogominho e as tropas da } \\
\text { Bahia. Reação nas Alagoas, no Rio } \\
\text { Grande e na Paraíba. Combate de } \\
\text { Ipojuca. Dissolve-se o Governo } \\
\text { Republicano. Os patriotas são remetidos } \\
\text { para a Bahia. Novas execuções naquela } \\
\text { Cidade. Luiz do Rego chega a } \\
\text { Pernambuco. Outros suplícios. A Alçada. }\end{array}$ & & \\
\hline
\end{tabular}




\begin{tabular}{|c|c|c|}
\hline $\begin{array}{l}\text { V. Proseguem as hostilidades no Sul. Vários } \\
\text { combates. Convenção de } 1819 \text {. Artigas } \\
\text { retido no Paraguai. Definitiva } \\
\text { incorporação de Montevidéu ao Reino } \\
\text { Unido de Portugal, Brasil, e Algarves. }\end{array}$ & & \\
\hline $\begin{array}{l}\text { VI. Revolução de Portugal em 1820. Seus } \\
\text { efeitos no Brasil. O Pará e a Bahia } \\
\text { pronunciam-se pela futura Constituição } \\
\text { Portuguesa. Soltura dos presos de } \\
\text { Pernambuco. Conduta de Luiz do Rego. } \\
\text { Acontecimentos do Rio de Janeiro. A } \\
\text { tropa e o Príncipe Real. Reunião eleitoral. } \\
\text { Os tiros da Praça do Comércio. El-Rei } \\
\text { embarca para Portugal. D. Pedro Regente } \\
\text { do Brasil. }\end{array}$ & & \\
\hline $\begin{array}{l}\text { CAPITULO SÉTIMO 1821 - } \mathbf{1 8 3 1} \\
\text { I. Primeiros atos do Príncipe Regente. } \\
\text { Influência das tropas portuguesas. Efeito } \\
\text { das medidas legislativas tomadas pelas } \\
\text { Cortes de Lisboa acerca do Brasil. S. } \\
\text { Paulo e o Rio de Janeiro se pronunciam } \\
\text { contra a partida do Príncipe. Embarque } \\
\text { da Divisão Lusitana. Convocação de um } \\
\text { Conselho de Procuradores das Províncias. } \\
\text { Novas desordens em Pernambuco e na } \\
\text { Bahia. }\end{array}$ & & \\
\hline $\begin{array}{l}\text { II. Uma Esquadra portuguesa chega ao Rio } \\
\text { de Janeiro. Sua volta. Viagem do Príncipe } \\
\text { Real a Minas. O título de Defensor } \\
\text { Perpétuo. Convocação da Assembléia } \\
\text { Constituinte. Manifestos. Viagem a S. } \\
\text { Paulo. O grito do Ipiranga. O Príncipe é } \\
\text { aclamado Imperador do Brasil. Coroação. }\end{array}$ & & \\
\hline $\begin{array}{l}\text { III. Sete Deputados Brasileiros abandonam } \\
\text { as Cortes de Lisboa. Lord Cockrane entra } \\
\text { no serviço do Brasil. Os Portugueses } \\
\text { evacuam a Bahia. Cochrane segue a } \\
\text { Esquadra Portuguesa alguns dias e volta } \\
\text { sobre o Maranhão. Sucessos do } \\
\text { Maranhão e do Pará. Horrível catástrofe. } \\
\text { A Divisão Lusitana capitula e evacua } \\
\text { Montevidéu. A Assembléia Constituinte } \\
\text { do Brasil. Demissão do Ministério dos } \\
\text { Andradas. Dissolução da Constituinte. } \\
\text { Deportação de seis Deputados. }\end{array}$ & & \\
\hline
\end{tabular}




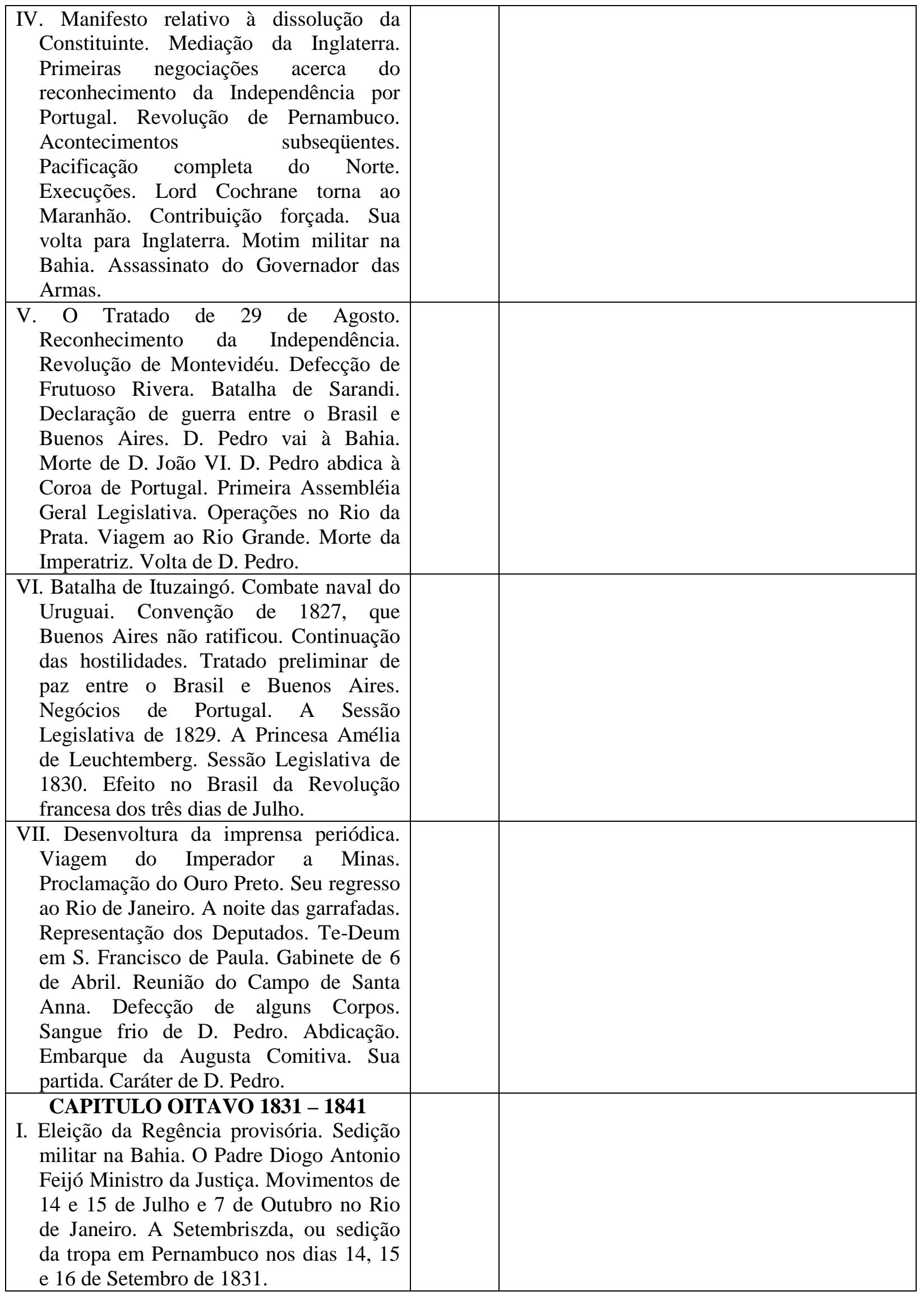




\begin{tabular}{|c|c|c|}
\hline \multicolumn{3}{|l|}{$\begin{array}{l}\text { II. Sociedades políticas. O Estado no } \\
\text { Estado. A Sociedade Defensora. Os } \\
\text { movimentos de } 3 \text { e } 17 \text { de Abril. O golpe } \\
\text { de Estado de } 30 \text { de Julho. O partido } \\
\text { Caramuru. A revolução do Ouro Perto. } \\
\text { Projeto de banimento do Ex-Imperador. } \\
\text { Estabelecimento da Sociedade Militar. Os } \\
\text { dias } 2,5 \text { e } 15 \text { de Dezembro de } 1833 \text {. } \\
\text { Quebramento das Tipografias. Prisão do } \\
\text { Tutor de S. M. I. e de suas Augustas } \\
\text { Irmãs. }\end{array}$} \\
\hline $\begin{array}{l}\text { III. Movimento de } 14 \text { de Abril em } \\
\text { Pernambuco. Guerra dos Cabanos. } \\
\text { Revolução do Ceará. Assassinato jurídico } \\
\text { de Pinto Madeira. Movimentos de } 13 \text { de } \\
\text { Setembro e } 19 \text { de Novembro de } 1831 \text { no } \\
\text { Maranhão. Guerra civil no interior. Morte } \\
\text { do Caudilho rebelde. Pacificação da } \\
\text { Província. O Pará desde } 1831 \text { até a } \\
\text { presente época. }\end{array}$ & & \\
\hline $\begin{array}{l}\text { IV. O banimento do Ex-Imperador. O Ato } \\
\text { adicional. Eleição do Padre Feijó para } \\
\text { Regente do Império. Revolução do Rio } \\
\text { Grande do Sul. Araújo Ribeiro e Bento } \\
\text { Manoel. Combate do Fanfa. Prisão de } \\
\text { Bento Gonçalves. Demissão de Araújo } \\
\text { Ribeiro. O Brigadeiro Antero Presidente. } \\
\text { Sua prisão. Feijó resigna o cargo de } \\
\text { Regente. Pedro de Araújo Lima Regente } \\
\text { interino. Revolução da Bahia. }\end{array}$ & & \\
\hline $\begin{array}{l}\text { V. A Bahia entra na ordem legal. Desastre } \\
\text { do Rio Pardo. Fuga de Bento Gonçalves. } \\
\text { Assassino do Presidente do Rio Grande } \\
\text { do Norte. Sedição de Raymundo Gomes. } \\
\text { Retirada do Caí. Tomada da Laguna. } \\
\text { Combate do Taquari. Luiz Alves de Lima } \\
\text { Presidente do Maranhão. }\end{array}$ & & \\
\hline $\begin{array}{l}\text { VI. Emenda ao voto de graças. Projeto da } \\
\text { Maioridade no Senado. Projeto de } \\
\text { reforma do artigo } 121 \text { da Constituição. } \\
\text { Adiamento da Assembléia Geral. A } \\
\text { reunião no Senado. O Quero já do } \\
\text { Imperador. Sua Majestade presta o } \\
\text { juramento constitucional. Ministério de } \\
24 \text { de Julho. Anistia de } 22 \text { de Agosto. } \\
\text { Sagração e Coroação do Senhor D. Pedro } \\
\text { II. Futuros do Brasil. }\end{array}$ & & \\
\hline INDICE Cronológico da História do Brasil. & & \\
\hline Documentos & & \\
\hline
\end{tabular}


Contudo, as fortes semelhanças não apagam as diferenças entre Compêndio e Lições; pelo contrário, elas constituem o pano de fundo que permite perceber, em uma primeira aproximação, as diferenças entre um compêndio que, a partir de uma intenção diversa, foi transformado em um "compêndio para a instrução pública", e um outro texto que manifesta tal intenção desde sua origem, devendo assim ser considerado estritamente um manual escolar, na segunda metade do século XIX, no Império do Brasil.

Mas não apenas isso. As semelhanças e diferenças entre ambas as obras, cuja leitura dos textos acentua, revelam também o solo no qual se nutriu a polêmica que marcaria de modo indelével a trajetória da obra de Abreu e Lima. Elas revelam uma faceta das lutas de representação no interior da elite letrada e, em termos mais amplos, da boa sociedade imperial, pondo em evidência assim as contradições vividas pelos dirigentes imperiais, sob a direção saquarema, no exercício de um domínio limitado aos do território do Império do Brasil.

\section{A POLÊMICA}

Destinos diversos! Apresentados à mesma instituição, quase ao mesmo tempo, os textos de Martius e de Abreu e Lima teriam destinos diversos. O pequeno texto de Martius alcançaria uma notoriedade que se estende aos dias atuais, constituindo-se em uma espécie de discurso fundador da historiografia brasileira. O Compêndio da História do Brasil receberia restrições de diferentes tipos por parte dos sócios efetivos do instituto.

Lida a carta por meio da qual Abreu e Lima oferecia seu compêndio ao Instituto, deliberou-se inicialmente pela nomeação de uma comissão especial ${ }^{86}$ com o encargo de emitir um juízo a respeito da obra. Muito provavelmente por influência do Secretário perpétuo da instituição, decidiu-se substituir o trabalho da comissão pelo de uma só pessoa, tendo sido designado Francisco Adolfo de Varnhagen para a elaboração de um parecer ${ }^{87}$. E assim

\footnotetext{
${ }^{86}$ A comissão era composta pelo conselheiro Bento da Silva Lisboa e pelo Dr. Diogo Soares da Silva Bivar.

${ }^{87}$ Vamireh Chacon afirma que "o Secretário Perpétuo do Instituto, o Cônego Januário da Cunha Barbosa encaminhou o Compêndio a uma comissão que apresentou sóbrio parecer. Mas eis que o Cônego, envolvido nos
} 
aconteceu: em um intervalo de tempo relativamente curto, Varnhagen apresentou ao Instituto o que denominou de "Primeiro Juízo" ${ }^{88}$ a respeito do Compêndio, cuja contundência deflagraria acirrada polêmica entre o sorocabano, e por extensão o IHGB, de um lado, e o pernambucano, de outro.

Antes de apresentar as principais observações críticas feitas por Varnhagen talvez valha a pena lembrar que este não era ainda o autor da História Geral do Brasil, cujo primeiro volume somente viria a luz uma década depois dos acontecimentos de que cuido agora. Não obstante, os estudos de crítica histórica que já elaborara, por essa época, credenciavam-no, ao menos no entender de Januário da Cunha Barbosa, para a tarefa que lhe era confiada, por demonstrarem que seu autor preenchia um dos requisitos necessários para a escritura da História do Brasil, em termos modernos. Um entendimento que propiciava uma íntima aproximação entre Varnhagen e o cônego.

Um "Primeiro Juízo" apresentado por meio de um texto denso, no qual conhecimento e erudição são temperados por não pouca dissimulação e ironia. Mas um "Primeiro Juízo", que parece anunciar um "segundo", um "terceiro" etc..., que não vieram à luz, talvez em decorrência da polêmica deflagrada, marcada por aspereza e mesmo certa incontinência verbal; talvez porque as preocupações de Varnhagen, do próprio Instituto e de Abreu e Lima tenham se modificado; ou talvez porque ao autor do "Juízo" jamais tenha ocorrido a intenção de ir além de um "Primeiro" e único juízo, considerando-o suficiente para os propósitos que tinha em mente, os quais talvez se confundissem com os do cônego. Afinal, Varnhagen avisa aos prováveis leitores de seu texto que analisara apenas "vinte e poucas páginas"; todavia, mesmo um leitor desavisado poderá concluir, acompanhando as páginas citadas de Compêndio na argumentação do parecerista e o leque de temas abordados, que ele lera (e, por vezes, analisara), além do "Prefácio", todos os cinco primeiros capítulos referentes à "história antiga", isto é, quase todo o primeiro tomo. É ele próprio quem diz:

acontecimentos da abdicação (...) influiu para que outra comissão, a de Legislação e não a de História, se pronunciasse de maneira não só negativa quanto contundente.” (CHACON, 1983, p. 161.(não sei qual das duas ) 88 "Primeiro Juízo". Submetido ao IHGB pelo seu sócio Francisco Adolfo de Varnhagen acerca do "Compêndio de História do Brasil’ pelo Sr José Inácio de Abreu e Lima” (REVISTA DO IHGB, t. VI, p. 60-83). 
Tirando uma ou outra nota, uma ou outra frase, todo o Compêndio desde pág. 27 até pág. 257 (do primeiro volume se entende, pois que o segundo é quase todo formado de documentos especialmente modernos de 20 anos para cá), todo o Compêndio, dizemos, não é mais do que um apontoado de pedaços da tradução portuguesa de Beauchamp (VARNHAGEN, 1978, p. 67). ${ }^{89}$

Se, além disso, ele optara por ignorar os três capítulos finais, chegando mesmo a afirmar que o segundo volume "é quase todo formado de documentos especialmente modernos", o "quase todo" sendo constituído por 188 páginas de um total de quase 360, tal opção certamente reforçaria a sugestão feita há pouco de que ao menos a parte referente à "história antiga" ele lera em detalhe, tendo optado deliberadamente por emitir um juízo apenas a respeito de "vinte e poucas páginas", ou seja, um "Primeiro (e único) Juízo".

Um "Primeiro Juízo" que se inicia de modo cortês ao sublinhar o valor de uma iniciativa:

"A falta de amor das velhas coisas da pátria", diz um dos primeiros representantes contemporâneos da literatura nossa co-irmã, - o meu ilustre Sr Alexandre Herculano - 'é indício certo da morte da nacionalidade e, por consequiência, do estado decadente e da última ruína de qualquer povo'. Não se tinham ainda passado horas depois de lermos estas linhas no "Panorama" de 28 de Outubro do corrente ano, quando nos vieram à mão os dois pequenos volumes de um - Compêndio da História do Brasil, pelo Sr. J. I. de Abreu e Lima, - os quais, pois que nenhumas velhas coisas da Pátria temos por demais importância que as respectivas à sua História, nos deram a doce consolação, como bem se pode crer, vindo eles em tal conjuntura, de mais uma prova de nada contender com o nosso país a frisante máxima profética enunciada. (p. 60).

Uma iniciativa que destacava, a par da "proteção e desvelo paternal" do monarca, o valor de seu autor - "um escritor já de outras obras, de que tínhamos ouvido falar" -, assim

\footnotetext{
${ }^{89}$ Daqui em diante, sempre que for o caso, a indicação página do texto aparecerá em continuação à citação.
} 
como o dos editores e artistas "pela distinta maneira com que promovem o adiantamento das artes, tipos e tipografias no nascente Brasil". Varnhagen associava, assim, ainda uma vez, o estado de civilização do Império do Brasil à difusão das luzes por meio dos textos impressos e dos personagens a eles associados: autor, editores, artistas.

Mas um modo cortês que, embora ainda reafirmado pela colocação em destaque de outras qualidades que teriam orientado a iniciativa, começa a ceder lugar a uma atitude oposta, na qual uma crítica tão arguta em determinados pontos quanto excessivamente dura em muitos outros, sempre fundamentada em conhecimento e erudição, era temperada por ironia e dissimulação, conforme dito há pouco.

À confissão do autor pernambucano "de que escrevia o seu Compêndio a rogo de outrem, e que não passava ele de uma compilação de períodos alheios", o parecerista contrapõe sua melancolia e tristeza, não tanto por ter tomado conhecimento que a deliberação de Abreu e Lima de formar um compêndio derivara do "rogo de outrem", o que podia ser "filha da modéstia, virtude que tanto orna o escritor público", mas por ter o seu autor escolhido copiar "a tradução Portuguesa de uma chamada História do Brasil, que corre como trabalhada por Alfonso de Beauchamp". E confessa: "Magoou-nos profundamente".

Mágoas que se transformam nas críticas que preenchem as páginas do "Primeiro Juízo". Mas, o autor das críticas adverte: "Não: as linhas que vamos escrever apenas têm a mira de se aproveitarem da garantia civilizadora que mais devem às ciências os seus progressos, isto é, da liberdade de discussão, única que termina por aclarar a verdade”. (p. 6566).

Apresentando-se tanto como alguém compreensivo quanto como severo censor, recorda que "um compêndio é, em qualquer ciência ou arte, o livro mais difícil de escrever, e que mais pertence aos abalizados grandes mestres. Se os Lalandes só escrevem os manuais depois dos grandes tratados em Astronomia, o que diremos de escrever Compêndios da História antes de estarem os fatos desta conhecidos e averiguados?”(p. 66) 
De maneira resumida, as críticas feitas podem ser reunidas em sete grupos principais: a ausência de um estilo próprio na composição do texto; a não utilização de documentos originais, quando estes se encontravam disponíveis; a imprecisão histórica dos retratos apresentados nas estampas; a ausência de consulta a obras de outros historiadores modernos; o fato de Abreu e Lima ter redigido uma nota em que cita dois documentos publicados por Varnhagen, mas de não os ter utilizado no texto principal, dando preferência ao texto de Beauchamp, cravejado de erros que já poderiam ter sido corrigidos; a utilização imprópria e indevida da designação Brasileiro para os primeiros habitantes do Brasil - "índios selvagens"; e, sobretudo, o fato de o autor de Compêndio ter escolhido para copiar a História do Brasil do "plagiário" Beauchamp, alguém "que como escritor público não inspira outro sentimento senão o do desprezo a quem louva a virtude, e respeita a propriedade mais sagrada que existe sobre a terra - a do entendimento"(p. 63). Não pretendo reproduzir as observações de Varnhagen a respeito de cada um dos grupos de críticas referidos. Ponho em destaque três delas apenas.

Ao autor do "Juízo" incomodavam fortemente alguns dos retratos que acompanhavam a obra. Muito à sua maneira própria de expor uma discordância, diz:

Embora os retratos inventados, como o do Chefe Índio Camarão (aliás Poti), e o de Henrique Dias, que só desejáramos para nossa instrução saber onde o Sr. Abreu e Lima descobriu que fora comprovinciano natural de Pernambuco, como diz à pág. 142, desagradem a opinião dos mais severos, que, crendo com fé viva na importância do passado reduzido a escrita (que se chama História), assentam se não deve assim despoetizar a crença com tais fantasias, preferindo antes o uso de bustos cegos, quando o fim que se pretende é o de substancializar e materializar a memória dos homens célebres. (p. 61)

Com relação ao uso do nome "Brasileiro", é enfático:

"E primeiro que tudo, digamos por uma vez para toda a obra, que não achamos próprio que se empregue a palavra - Brasileiro - tratando-se dos 
índios selvagens, e da mesma expressão adjetiva, referindo-se às castas e nações indígenas; e isto é porque temos, além deste último nome de indígenas, o impróprio, mas já recebido de Índios, ao qual podemos acrescentar as respectivas das mesmas nações, etc. Por este meio se evitaria certos quiproquós que aparecem no Compêndio, tais como: - 'nem todos os Brasileiros eram antropófagos'. 'Os Brasileiros não são geralmente polígamos, ainda que alguns possam ter diversas mulheres'. - Podemos ainda em casos tais usar dos adjetivos Brasiliense, Brasiliano; e quando em referência aos indígenas, o nome de Brasis, que é o único empregado pelos clássicos e que tem a vantagem de ser mais curto".

E complementa por meio de uma nota, que transcrevo em parte:

A expressão - Brasileiro - quando empregada substantivamente parece que se liga já a certa idéia de cidadão civilizado: é o único adjetivo de quantas nacionalidades ora nos ocorrem, que do país Brasil se acrescentou a terminação em - eiro - que na língua portuguesa é designativa de um continuado exercício, tráfico, ofício que o princípio inculca, v.g. sineiro, caminheiro, boleeiro, roceiro, pedreiro \& c., de sino, caminho, boléa, roça, pedra, etc. (p. 70).

Mas é na crítica à escolha de Beauchamp como texto básico para ser compendidado, que Varnhagen mais se expande. Se se diz magoado por uma escolha é porque não só conhece "quantos usos, invenções e falsidades iam ser comunicadas aos nossos jovens", mas também porque tal escolha acabava por atribuir àquele autor - "um homem já com antiga praça assente no regimento dos Plagiários" - uma importância e um valor imerecidos. Mas, ao exercitar a crítica, Varnhagen aparenta cautela, e mesmo uma certa generosidade, ao rogar ao autor de Compêndio

que aceite os nossos protestos firmes de que só o amor do justo é que nos move, e que ainda assim somos tão pouco propensos a polêmicas, e prezamos tanto respeitar os melindres do autor, que quanto fica dito e vamos 
a dizer nada houvéramos escrito, a não ser a persuasão, em que estamos, de que com este serviço, que desejamos prestar ao país e ao Instituto, a cujo exame submetemos este primeiro esboço do nosso juízo, só a alguns parágrafos da obra, em nada vamos ofuscar a sua reputação, nem tão pouco prejudicar os dignos editores, que tão generosamente se prestaram à publicação de uma História nacional com tanta nitidez. (p. 65).

Ao dirigir contundente ataque ao plagiário francês, Varnhagen refere-se à História do Brasil de Robert Southey, o literato e poeta inglês "que teve a boa inspiração de escrever uma História do Brasil, não só quando ele não era ainda independente, mas até antes da época em que na Europa se olhou mais a sua importância pela transferência da Casa de Bragança”. (p. 63) Varnhagen monumentaliza a obra de Southey, cujo primeiro volume fora editado em inglês em 1810. Ele argumenta que Beauchamp a plagiara; e a Abreu e Lima faltara o bom senso de a não ter escolhido para compendiar. Beauchamp não apenas plagiara Southey, tendo ainda produzido erros imperdoáveis a respeito da História do Brasil em seu próprio livro, editado em Paris em 1815; e Abreu e Lima copiara acriticamente a tradução portuguesa do livro de Besauchamp. Mas Varnhagen não deixa de afirmar: "Não é com o Sr Lima que temos que tratar, mas sim com o plagiário francês." 90 A leitura do "Primeiro Juízo" revela algo diverso, uma vez que, à medida que seguimos por suas páginas, as críticas ao plagiário vão se transformando em críticas a um mau leitor e a um mau copista, a alguém que intentara escrever a História do Brasil, mas que não reunia os elementos suficientes para tal.

Críticas com alvos bem definidos, embora nem todos eles tenham sido destacados aqui. Varnhagen atinge o panteão pernambucano que Abreu e Lima ajudava a erigir, ou no mínimo rememorar, quer negando autenticidade às imagens dos heróis que não eram brancos, quer recusando a naturalidade pernambucana do negro Henrique Dias. Ao se colocar contra a atribuição de uma denominação, ele se opõe a uma filiação entre os primeiros habitantes da terra e os seus ocupantes na atualidade, reservando a denominação brasileiro ao que "parece

\footnotetext{
90 "Este outro artigo, que até o título tem copiado da tradução que mencionamos, ainda desejávamos, mais do que no antecedente, trancrever todo, pondo ao lado o texto de que lhe é plágio. Com isso mostraríamos claramente ao leitor que, como dissemos, quase todas as considerações que vamos fazer nada tem com o autor de Compêndio, mas sim com aquele em que S.S. se confiou demais, a ponto de o copiar por hábito." (p. 73, grifo meu).
} 
que se liga já a certa idéia de cidadão civilizado". E, ainda na mesma nota acima transcrita, não deixa de jogar de modo habilidoso com a relação que os nascentes Estados nacionais faziam entre $o$ ato de nascer e o de pertencer a uma nação a partir da origem comum de ambas as palavras, uma vez que nascer vem de nascor e que do mesmo verbo latino deriva natio, onis, que dá origem a nação na língua portuguesa. Lembra então que "o nosso adjetivo de nacionalidade não derivou imediatamente da terra, mas sim do produto no princípio mais exclusivo dela, que lhe fez mudar em Terra do Brasil o nome de Santa Cruz." (p. 70) Mas o "Juízo" de Varnhagen vai mais além: ao desqualificar o livro de Alfonso de Beauchamp; ao sublinhar a ausência de um estilo próprio na composição do texto; ao pôr em relevo quer a não utilização de documentos originais quer a ausência de consulta a obras de outros historiadores modernos; ele desqualificava em seu conjunto o Compêndio da História do Brasil, de Abreu e Lima. Tornavam-se necessários outros “juízos” do mesmo autor?

A avaliação feita por Varnhagen somava-se a outras avaliações levadas a cabo por outros membros do IHGB, de modo formal ou por meio de conversas informais. A expressão de uma recusa ou de uma censura estava contida na afirmativa, repetida em diferentes oportunidades, de que o Resumo de História do Brasil de Henrique Luiz de Niemeyer Bellegarde, publicado em 1831 e reeditado em 1834, era superior a Compêndio. ${ }^{91}$ No fundamental, todas aquelas avaliações todas elas pareciam repetir um mesmo princípio: a escritura da História do Brasil deveria se orientar exclusivamente pelos pressupostos fixados pela instituição. ${ }^{92}$ Posto sob a proteção do Imperador, o IHGB permanecia sob o olhar vigilante de Januário da Cunha Barbosa. Naquele mesmo ano de 1844, José Inácio de Abreu e Lima abandonou a Corte imperial, regressando à sua pátria.

Todavia, o "Primeiro Juízo" não ficaria sem resposta. Abreu e Lima redigiu textos também contundentes em defesa de seu Compêndio; textos nos quais - no entender do Cônego Januário da Cunha Barbosa - teria "ultrapassado os limites da decência."

\footnotetext{
${ }^{91}$ Segundo José Honório Rodrigues, o livro de Bellegarde era "um compêndio elementar então adotado nas escolas". (Cf. RODRIGUES, 1957, p. 158).

92 "Toda pesquisa historiográfica é articulada a partir de um lugar de produção sócio-econômico, político e cultural. Implica um meio de elaboração circunscrito por determinações próprias: uma profissão liberal, um posto de estudo ou de ensino, uma categoria de letrados etc. Encontra-se, portanto, submetida a opressões, ligada a privilégios, enraizada em uma particularidade. É em função desse lugar que se instauram os métodos, que se precisa uma topografia de interesses, que se organizam os dossiers e as indagações relativas aos documentos." (CERTEAU, 1976, p. 18).
} 
Eram três textos, somando 123 páginas, publicados pela Tipografia de M. Faria, em Recife, no mesmo ano de 1844. O primeiro deles era dirigido "Ao Público"; o segundo constituía uma "Resposta do General ao Cônego"; e o último, dirigido a Francisco Adolfo de Varnhagen, intitulava-se “Análise do Primeiro Juízo” (ABREU E LIMA, 1844).

Em "Ao Público", o leitor era informado que, em respeito às normas elementares de educação, civilidade e de sua condição de súdito, Abreu e Lima oferecera ao Imperador uma brochura de seu compêndio, antes de publicá-lo. Tendo sido informado do agrado que a leitura provocara em Sua Majestade Imperial, "tomara a deliberação de ir pedir seu consentimento para dedicar-lhe o meu trabalho." Obtendo a aquiescência imperial, levou-lhe, em seguida, uma cópia da dedicatória que escrevera.

Recebeu-me imediatamente com todo agasalho e lendo o autógrafo, que eu lhe apresentava, sem nenhuma outra formalidade das que se usam em tais casos. Disse-me com toda a urbanidade e imperial benevolência, que a aceitava e que eu podia mandá-la imprimir. Beijei-lhe a mão e o Nome Augusto de D. Pedro II saiu à frente de minha obra. (p. IV-V)

Por meio de uma rememoração, o autor de Compêndio demonstrava aos que ainda podiam duvidar que conhecia a gramática do sistema monárquico. Mas rememorava também para poder dizer que, em um primeiro momento, tomara a resolução de não responder às críticas formuladas por Varnhagen e outros, mudando mais tarde de opinião: decidira provar que o Imperador não se equivocara quando da sua leitura - Compêndio era digno da sua proteção.

Ler a "Resposta ao Cônego" Januário da Cunha Mattos é compreender, entre outras coisas, por que o texto precede a análise do parecer de Varnhagen. Abreu e Lima denuncia, de imediato, o descaso com que fora tratado: o parecer, uma espécie de sentença, proferida pela “Comissão de Redação da Revista Trimestral do IHGB, em janeiro de 1844", não lhe fora comunicado, só tendo tido acesso ao mesmo quando da sua publicação, três meses mais tarde. Rememora que o cônego Januário - "o Instituto encarnado" - o vinha insultando 
publicamente, por vezes protegido pelo anonimato, desde os idos de 1834 , ocasião em que dirigira o "Correio Oficial" e a "Mutuca Picante". Coloca sob suspeita a legitimidade das resoluções do IHGB ao enfatizar o fato de apenas "meia dúzia de parasitas" a elas comparecem (p. 6). Ressalta que ao desqualificar Beauchamp, Januário também insultava outros homens de letras, uma vez que a obra de Beauchamp não fora recusada por todos: as qualidades positivas e também os equívocos do escritor francês eram reconhecidos por um número significativo de homens cultos e prestigiosos, como o Visconde de Cairú. ${ }^{93}$ Em resumo, entre aqueles que se dedicavam às letras parecia não haver dúvidas a respeito da atuação do Cônego à frente da instituição, que havia muito se transformara no "Instituto do Januário" - era ele, reconhecidamente, o mentor da difamação que sofria.

Se em "Ao Público" e "Resposta" Abreu se dirige aos leitores em geral, em "Análise do Primeiro Juízo" o autor, ainda que não deixe de se dirigir àqueles leitores, interpela Varnhagen de forma direta, clara e inequívoca, servindo-se de uma linguagem por vezes dura, por vezes também irônica e dissimulada.

“Análise" é iniciada com a colocação sob suspeição da nacionalidade brasileira do historiador sorocabano, cujo "apelido bem mostra que não pertence a nenhuma família conhecida no Brasil, entretanto que ele se intitulou brasileiro - brasileiro puro". Abreu e Lima afirma que Januário e outros tinham se dedicado a "metamorfosear um moço português em cidadão brasileiro", e daí derivava a submissão de Varnhagen ao Secretário do IHGB.

E somente após explorar este ponto, o pernambucano daria inicio à sua "tarefa literária" de refutar as críticas que foram feitas ao seu trabalho. Em seu transcurso, em não poucas oportunidades reapareceriam antigas questões e desavenças que haviam marcado a trajetória de todos aqueles personagens durante a experiência regencial, a escrita da História ou a discussão a respeito dela - confundindo-se de modo inextricável com a experiência vivida por aqueles homens. Também aqui somente me ocuparei da resposta a algumas das

\footnotetext{
${ }^{93}$ À História do Brasil de Beauchamp recorriam diversos membros do IHGB, sendo relativamente fácil encontrar citações dela retiradas em diversas memórias publicadas na Revista, como em textos de Machado de Oliveira, cf. "Programa", Revista do IHGB, 1844.
} 
críticas, com o intuito de melhor caracterizar os pontos de vista e pressupostos que orientavam a atuação de Abreu e Lima como historiador.

Seguindo em sua argumentação quase que estritamente a ordem das observações e críticas feitas por Varnhagen, o autor de Compêndio começa por refutar as críticas feitas às imagens. Recorda terem sido elas uma proposta dos Laemmert, que achara boa e acatara. Mas recorda também que ficara descontente ao ver os retatos e constatar que o artista havia desenhado os personagens trajando roupas de outra época, anacronismo que só um ignorante não observaria. E Varnhagem fora incapaz de perceber o quanto destoavam as vestes de cada um dos retratados. Com relação à preferência do parecerista por bustos cegos, Abreu e Lima recorda os retratos inventados dos Marechais da França expostos "no palácio das Tulherias e nos Inválidos", e colocados ali anos após a morte dos militares. Os artistas que desenharam os retratos basearam-se nos traços fisionômicos dos famliares dos generais. E, como se julgasse que tais argumentos não eram suficientes, pergunta se há dois retratos iguais de Bolívar e D. Pedro, ou como Rubens pode pintar o descimento da cruz? A invenção, diz Abreu e Lima discordando de Varnhagen ou daqueles que, no texto de Varnhagen, apareciam como críticos anônimos das estampas, não "despoetiza a crença" nos retratados. ${ }^{94}$ Em estilo suscinto, esclarece não haver dificuldade alguma para qualquer estudioso que não tenha feito "ofício maquinal de copista" descobrir a naturalidade de Henrique Dias: a carta que Dias escrevera aos holandeses, extraída de $\mathbf{O}$ valoroso Lucideno, de Fr. Manoel Calado, podia ser encontrada no tomo III da Revista do IHGB. E conclui, com orgulho: "Pernambuco é sua pátria e minha” (p. 34).

Em meio a lembranças e evocações dos anos recentes, Abreu e Lima relembra que a resolução de escrever Compêndio surgira quando do término da leitura das obras de Aneillon e de Matter, O quadro das revoluções do sistema político da Europa e História das

\footnotetext{
${ }^{94}$ Independentemente dos diferentes critérios de verdade que orientam os procedimentos diversos de Varnhagen e Abreu e Lima, na discussão a respeito dos "verdadeiros" rostos a serem retratados, uma interessante formulação a respeito encontra-se em Geografia imperfeita de Corto Maltese, onde após sustentar que "os desenhistas desenham a si mesmos em seus protagonistas", Umberto Eco conclui que "assim se faz errático um texto. E é nessa bruma que afeta espaço e tempo que nascem os mitos, e os personagens emigram para outros textos, instalam-se como nativos na nossa memória como se tivessem existido desde sempre na memória de nossos pais, jovens como Matusalém e milenares como Peter Pan, de tal modo que acontece freqüentemente de encontrá-los mesmo onde não são contados e até - pelo menos isso é concedido às crianças - na vida". In Entre a memória e a ironia. Rio de Janeiro: Record, 2006, p. 126.
} 
doutrinas morais e políticas dos três últimos séculos, respectivamente. Os textos o haviam impressionado porque em ambos encontrara "o melhor método de escrever a história pela maneira como se achavam concebidos seus planos" (p. 39).

Em sua opinião, nas duas obras surgiam traçadas com clareza as épocas, os períodos e as transformações ocorridas nas artes, na política e nas ciências, nos três últimos séculos. Se a escrita da História, segundo as regras da cronologia, não podia prescindir da perfeita divisão das épocas, a convicção de ter em mãos um grande plano viabilizou a idéia de aplicá-lo à História do Brasil.

Concebi então a idéia de aplicar este grande plano à história do Brasil, e comecei a estudar e a rever o que me pode cair nas mãos. O único corpo de história completo, que encontrei, foi a obra de Southey, mas notei logo tantos defeitos, tantos vícios de conformação, que preferi antes ir beber à fonte pura, porque o que eu procurava eram os grandes fatos, os acontecimentos mais notáveis, como pontos cardeais do meu plano. Achei pois a minha primeira época perfeitamente concebida pelo padre Casal, e as outras em Rocha Pita, Brito Freire, Simão de Vasconcelos, Armitage etc, porque eu só queria os grandes acontecimentos, que me servissem de balisa para demarcar as épocas, como disse na minha carta ao Instituto, e não sei se foi, ela aproveitada para o programa que ali se deu, a respeito das épocas da História do Brasil.

Após ter concluído a formatação de um quadro sinótico com a definição das diversas épocas ouvira de um amigo a sugestão de escrever um compêndio de história do Brasil. Relata que o primeiro esboço que fizera "tanto poderia convir para uma história em grande como para um resumo ou compêndio; pois que só faltava preencher os períodos de cada época, colocando os fatos secundários na ordem cronológica, e fazendo-os entrar no lugar e tempo correspondente por meio de uma narração adequada; isto é, obrar do mesmo modo que se tivesse que levantar uma Carta sobre um terreno perfeitamente triangulado" (p. 40-41). Após ter estudado novos textos e procedido a revisão de obras que já estudara, tomou a decisão de escolher a tradução portuguesa de História do Brasil de Beauchamp. 
Recorda ter lido pela primeira vez os textos de Beauchamp, Handerson e Southey há mais de duas décadas quando fora incumbido de escrever uma memória sobre as fronteiras entre a Colômbia e o Brasil a pedido do governo colombiano. Embora continuasse guardando os extratos que fizera preferiu, mais uma vez, estudar a obra de Southey quando tomou a resolução de escrever o Compêndio. A ajuda providencial de Emílio Joaquim da Silva Maia lhe proporcionara o acesso à referida obra e a outras sobre a História do Brasil. "Muitas vezes tenho tido em minha casa, e por meses, a história de Southey, como pode atestar o mesmo Sr. Dr Maia” (p. 49). Para o general de Bolívar, a obra de Southey

é o primeiro corpo da nossa história, o mais completo que apareceu, e nisso consiste todo o seu merecimento; porém corpo monstruoso, com grandes deformidades, com excrecências que afeiam, e tornam irregulares o seu todo. Assim é que estes três volumes não abrangem tão somente a História do Brasil, mas também a de Buenos Aires em grande parte, a do Paraguai, e muitas relações intercaladas de descobrimentos interiores até o Alto Peru pelo Oeste, e pelo Sul até o Chile. O autor diz que só escrevera desses países o que tinha relação com o Brasil, porém eu poderia apontar capítulos inteiros, nenhuma vantagem, nenhum interesse tem para a nossa história (p. 43). ${ }^{95}$

Por tais razões, prefirira seguir o escritor francês, porque sua obra “[...] já reduzida a fatos nacionais, sem o apêndice de outros inteiramente estranhos, que tranformam a unidade da história sem argumentar seu interesse" (p. 47).

Em seu entender Beauchamp não era um escritor desconhecido ou desacreditado, como afirmavam tanto Varnhagen como Januário, pois alcançara importância como escritor legitimista e era admirado na Europa. ${ }^{96}$ Afirmava não desconhecer o método de trabalho

\footnotetext{
${ }^{95}$ Este trecho da "Análise" ajuda a compreender o que disse acima a respeito do território nacional que delimita a narrativa de Compêndio.

${ }^{96}$ De acordo com Abreu e Lima, o historiador francês alcançara prestígio como escritor legitimista ao publicar A história da guerra da Vandéia; com a publicação dos dois volumes de Memoires tirés des papiers d'un homme d'Etat, em 1831, teria ganho maior admiração na Europa. Todavia, não é improvável que a qualidade de "legitimista" do historiador francês tenha contribuído para as restrições feitas por Januário e Varnhagen.
} 
eleito pelo escritor francês para compor parte significativa de sua História do Brasil, no qual o primeiro volume do trabalho de Southey desempenhara papel relevante.

Beauchamp não se equivocou sobre o efeito de sua obra, porque na realidade teve logo duas traduções, uma em Portugal, e outra no Brasil; enquanto a de Southey ainda não mereceu esta honra até hoje, nem a terá de certo, se daqui por diante quizermos cuidar sobre as nossas próprias coisas; o que é muito natural que aconteça, apesar dos Januários e Varnhagens das quatro partes do mundo. (p. 47).

A demora na publicação do $2^{\circ}$ volume da obra de Southey, fez com que Beauchamp seguisse outros caminhos, consultasse outros autores podendo assim concluir a obra. Ainda assim, o texto final apresentava lacunas, "porque visivelmente não leu a Fr. Gaspar da Madre de Deus, pois não traz nenhum dos fatos especiais, que este autor refere, e que eu introduzi em notas muito de propósito, para não alterar o texto". (p. 48, grifo meu).

À acusação de ter realizado uma compilação Abreu e Lima contra-argumenta, em texto longo, mas elucidativo:

[...] à exceção da história contemporânea, porque são fatos presenciais, não conheço historiador nenhum que não fosse compilador. Ouça bem, Sr. Varnhagen, pois já lhe disse: os fatos não se inventam; estão consignados na história já escrita por outrem, ou em documentos e registros auntênticos; servir-se pois da história antiga ou de documentos, ou de uma e outra coisa, é vertê-los em linguagem nova, se assim se quiser, ou copiá-los, eis aí o que se chama compilar; isto é, reunir em um corpo ou livro coisa ou materiais extraídos de vários autores. Já vê o Sr. Varnhagen que disse um grande disparate só porque ignora a sua língua.

Alguns preferem traduzir esses fatos, ou materiais, em linguagem própria, porém eu preferi conservá-los na frase alheia muito de propósito (entende, Sr. Varnhagen?) como disse no meu Prefácio; quis deixar a cada autor a responsabilidade dos seus erros, porque hoje possuo um tesouro de documentos, que nunca teriam vindo às minhas mãos sem este primeiro 
esforço. Se o Sr. Varnhagen soubesse que desde Francisco da Cunha e Gabriel Soares (que pelo nome não perca) até sua eruditíssima pessoa não há um só escritor que não tenha erros, e erros muito graves, não só sobre a história como sobre a geografia do Brasil, veria que não me é possível sair desse labirinto sem grande adjutório, que não tive; mas hoje que o meu trabalho tem merecido geral aprovação, exceto do Instituto, tenho tido a fortuna de que os meus amigos, e muitas outras pessoas, que eu antes não conhecia, me tenham franqueado manuscritos preciosos, esclarecimentos importantes e até documentos cuja existência era geralmente ignorada. Saiba mais o Sr. Varnhagen, que desde a Introdução corográfica, ou descrição do país até o fim do meu Compêndio tenho já corrigido mais de vinte erros, que não foram meus, nem os compreende o Sr. Varnhagen, porque de nenhum deles fez menção, tanta é a sua ignorância das coisas do Brasil. Já vêm os leitores, que por este andar terei que fazer um livro in folio em lugar de uma resposta; mas o que fazer? (p. 37-38).

A citação longa me parece importante porque permite compreender, ao menos em parte, o ponto de vista defendido por Abreu e Lima a respeito de várias questões que dizem respeito à polêmica, e até mesmo outras que a tangeciam.

Creio ser de alguma valia recordar que Compêndio fora escrito e editado no tempo em que o nacionalismo e o romantismo davam os contornos de uma literatura brasileira que, segundo alguns contesmporâneos, só então surgia. Em meados do XIX, a estética romântica convivia com a retórica, que não havia sido posta de lado pelos homens de letras. Os príncipios da retórica permaneciam sendo aceitos e utilizados na organização das formas de pensamento e linguagem. No Imperial Colégio de Pedro II, as aulas de retórica e poética permaneciam ocupando lugar central na formação dos alunos. ${ }^{97}$

Tanto Roberto Acízelo de Souza quanto Eduardo Vieira Martins, cada qual a seu modo e com seus próprios interesses, ao tratarem da relação entre romantismo e retórica e se

\footnotetext{
${ }^{97}$ Segundo Roberto Acízelo de Souza, desde 1839 o ensino de retórica era oferecido aos alunos deste colégio, sendo que entre 1850 e 1900 a retórica e a poética ocuparam lugar de destaque entre as disciplinas escolares. (SOUZA, 1999b, p. 26; p.2).
} 
dedicarem a analisar o ensino e os manuais escolares de eloqüência, poética e retórica, nos ajudam a compreender como, à época da publicação de Compêndio, a cópia de textos de autores consagrados era, além de plenamente aceita, considerada importante e significativa.

As obras consultadas e utilizadas pelos escritores deviam ser reproduzidas, isto é, expostas ao conhecimento do leitor, e não ocultadas. Assim, conforme destaca Martins,

[...] tomada como critério de valor, a categoria de imitador é externa à retórica, que previa a imitação e a emulação como artifícios válidos. Por isso, em vez de ocultar as fontes, o retórico, de quem não se esperava originalidade, freqüentemente as ostentava diante do leitor." (MARTINS, 2005, p. 27).

Entre os manuais escolares analisados por Martins, Lições elementares de eloqüência nacional, de Francisco Freire de Carvalho, apresenta no prefácio "os autores excelentes, que consultei e que até em grande parte copiei”, para em seguida nomeá-los: autores antigos e modernos. Em outro manual dedicado à poética nacional, o mesmo autor torna público o respeito às normas vigentes: "tudo quanto se encontra de bom na minha obra, foi extraído, recopilado, e até muitas vezes literalmente copiado de tão insigne Autor: não havendo quase nada de meu, senão alguns exemplos de poetas portugueses".

Se Acizelo de Souza parece associar, em um primeiro momento, essa ausência de originalidade ao que identifica como um objetivo didático de muitas das obras que analisou, em seguida sublinha que ela era proveniente de uma outra concepção de autoria, que caracteriza como "uma idéia pré-iluminista de autor", a qual, em não poucos casos, se expressava quer no próprio anonimato quer na "pulverização da unidade autoral e correlato descompromisso com a idéia de originalidade". Ele segue, de perto, os ensinamentos de João Adolfo Hansen, o qual destaca:

“[...] a auctoritas sistematizada pela Retórica, pela Retórica para Herênio, pelo De oratore, pela Institutio oratória, e a partir do século XV, que a 
descobre, pela Poética, não conhece o autor como se define a partir do século XVIII romântico: como originalidade de uma intuição expressiva; como unidade e profundidade de uma consciência; como particularidade existencial num tempo progressista; como psicologia do estilo; como propriedade privada e direitos autorais. No discurso antigo, enfim, auctor e auctoritas especificam um gênero, um uso ou uma disciplina" (HANSEN apud JOBIM, 1992).

Assim, compendiar (ou copiar) afastava-se da noção de plágio; pelo contrário, era o procedimento adequado para atribuir autoridade ao texto apresentado, que se distinguia exatamente por uma ausência quer de originalidade quer de estilo próprio, o que, aliás, não deixara de ser posto em destaque por Abreu e Lima no Prefácio de Compêndio. Mas uma forma de proceder que se, em meados do século XIX, ainda era corrente entre grande parte dos homens de letras do Império do Brasil, deixava de ser para uma outra parcela não menos significativa. Desta faziam parte aqueles que, como Januário e Varnhagen, associavam-se a uma maneira nova ou moderna de conceber a História e, conseqüentemente, praticar a sua escrita. Para eles, o antigo modo de escrever a História não respondia às questões postas pelo presente, sendo importante proceder de um modo diverso, do qual fazia parte sem dúvida a crítica dos testemunhos, fossem eles clássicos ou não, autorizados pela tradição ou não, dentre outros procedimentos. À verdade derivada da autoridade era contraposta a verdade derivada do método crítico, realizado por um autor moderno: o historiador. Para o jovem Varnhagen, o pernambucano não só não o realizava como ainda desprezava os trabalhos dele resultantes, como era o caso de seus próprios estudos. Logo, compendiar e copiar deveriam ser questionados e, no limite, não utilizados como práticas do fazer historiográfico. Encontrava-se aí, com certeza, uma das razões do veto que, pouco antes, o mesmo Januário apresentara à proposta de Justiniano José da Rocha para a elaboração de um compêndio da História do Brasil que lhe servisse em suas aulas no Colégio de Pedro II, conforme vimos anteriormente. Duas lógicas diversas, e até certo ponto irredutíveis; duas concepções de verdade; duas maneiras de escrever a História; duas concepções diversas de História.

Mas duas lógicas cujos defensores, por vezes, pareciam trocar de lado. Assim, Abreu e Lima acusaria Varnhagen de proceder justamente do modo como ele próprio procedia. Ao 
tratar do que diz ser a maior mágoa de Varnhagen - o fato de ele ter escolhido a tradução portuguesa de Beauchamp para formar o Compêndio - convida os leitores a compararem o prefácio da História do Brasil de Southey com o trecho de "Primeiro Juízo" nas páginas 63 e 67.

Nas cinco páginas em que trata deste escritor [Beauchamp], não diz uma só coisa de sua casa senão injúrias; o mais tudo é furtado dos dois Prefácios de Southey, do $1^{\mathrm{o}}$ e $2^{\mathrm{o}}$ volume da sua História do Brasil. O Sr. Varnhagen é tão ignorante que não sabe quem seja Beauchamp, nem ao menos goza de sua reputação literária. Tudo quanto diz acerca da obra de Southey foi um plágio feito ao Prefácio deste autor, que vem na $2^{\mathrm{a}}$ edição do $1^{\mathrm{o}}$ volume, acrescentando algumas sandices de sua casa, entre as quais a de pôr a Southey, como historiador, em reputação imediata a Lord Byron e a W. Scott, primeiros nomes que lhe ocorrerem para encher o fraseado de pedante. Acerca de Beauchamp foi o gatuno ainda mais miserável, porque nada mais disse senão o que encontrou no Prefácio do $2^{\circ}$ volume do próprio Southey. Desejaria poder copiar aqui estes dois Prefácios, assim como o plágio do Sr. Varnhagen, para que se visse até onde chega a petulância desse bilhostre; porém, pelo amor de Deus! Não me é possível compor um livro in folio. Peço, portanto encarecidamente aos meus leitores, que comparem os dois citados Prefácios de Southey com as 5 páginas do Juízo do Sr. Varnhagen, (desde 63 a 67), e ver-se-á exatidão do que acabo de dizer (p. 42-43).

A mesma lógica argumentativa, referida ao valor do plágio, fundamenta a sua recusa à acusação de Varnhagen de que, caso tivesse seguido a opinião dos historiadores modernos e a de Martius, não teria afirmado a existência de uma "nação de Tapuias": "ora, um pobre plagiário como eu, que opinião queria o Sr Varnhagen que tivesse senão a do autor, que copiei com uma boa fé tão singela, e que tanto magoou o seu sincero?". Recusando ou desconhecendo o exercício da crítica, Abreu e Lima desafia seu crítico a citar apenas o nome de um historiador português ou brasileiro que tivesse afirmado a inexistência do povo tapuia. 
Em relação a Martius, admira o vasto conhecimento do naturalista a quem muito deve a ciência, e em particular o Brasil, por sua contribuição para o desenvolvimento do saber médico. No entanto, rejeita sua autoridade como historiador e principalmente como geógrafo, afirmando não haver "homem que tenha sangue e coração brasileiro, que a não repila uma e mil vezes" (p. 54).

Para o autor de Compêndio é impossível esquecer o perigo que significaram as incursões francesas sobre o território do Império, a qual era fundamentada na "Carta do Brasil” elaborada por Spix e Martius.

Ora, os Srs. Spix e Martius não ignoravam o conteúdo do art. $1^{\circ}$ do Tratado de 28 de agosto de 1817, assinado em Paris, e muito menos o artigo 107 da Ata do Congresso de Viena de 9 de julho de 1815; portanto se esse erro geográfico, que tanto nos ia prejucicando, não foi, nem podia ser filho da ignorância, podíamos com razão atribui-lo à causa bem pouco honesta para esses senhores. Entretanto a acusação foi pública, e não me consta que o Sr. Martius se dignasse, ao menos por gratidão a este povo, que tão bem o acolheu, dizer a causa, não digo do seu e erro, mas do seu engano. Enquanto existir esse interdito, saiba o Sr. Varnhagen que o Sr. Martius não é autoridade para mim em história do Brasil, e ainda muito menos em geografia (p. 54-55).

Por fim, considera descabida a controvérsia sobre o significado e o uso do nome brasileiro. Em sua opinião, a utilização do termo estava assentada entre os contemporâneos, sendo prática reconhecida pelo dicionarista Constâncio que fazia uso do mesmo. Rejeita a crítica de Varnhagen sobre impropriedade do uso da palavra quando referida aos índios selvagens e às nações indígenas, concluindo ser compreensível a preferência de Varnhagen, "como bom português", por brasis. De acordo com o pernambucano Abreu e Lima, tanto tempo após a nossa Independência era ela a palavra preferida em Portugal - "os nossos brasis". 
O desfecho é evidente. Abreu e Lima não responde de forma direta à crítica por não ter utilizado os textos do próprio Varnhagen no texto de Compêndio. Mas não deixa de registrar que se arrependia de o ter tratado "com urbanidade e gentileza de cavalheiro, quando mostrei o absurdo de suas errôneas opiniões com tanta moderação e respeito" (p. 42).

Afinal, "o sr. Varnhagen até hoje nada tem feito de própria lavra, além de algumas notas e reflexões, que só para dar má nota de si se empenhara em estampar" (p. 37-38). 


\section{CONCLUSÃO}

Água Comprida, 29 de março: (...) As revoluções que se operaram em Portugal e no Rio de Janeiro não tiveram a menor influência sobre os habitantes desta zona paulista; mostram-se absolutamente alheios às nossas teorias; a mudança de governo não lhes fez mal nem bem, por conseguinte não se tem o menor entusiasmo. A única coisa que compreendem é que o restabelecimento do sistema colonial lhes causaria dano, porque se os portugueses fossem os únicos compradores de seu açúcar e café não mais venderiam suas mercadorias tão caro quanto agora o fazem. Professam, como outrora, o mesmo respeito pela autoridade, falam sempre do Rei como árbitro supremo de suas existências e da de seus filhos. É sempre ao Rei que pertencem os impostos, as passagens dos rios etc.

Vila de Taubaté, 17 de abril: O povo nada ganhou absolutamente com a mudança operada. A maioria dos franceses lucrou com a Revolução que suprimiu privilégios e direitos auferidos por uma casta favorecida. Aqui, lei alguma consagrava a desigualdade, todos os abusos eram o resultado do interesse e dos caprichos dos poderosos e dos funcionários. Mas são estes homens que, no Brasil, foram os cabeças da Revolução; não cuidavam senão em diminuir o poder do Rei, aumentando o próprio. Não pensavam de modo algum nas classes inferiores. Assim, o pobre lastima o Rei e os capitãesgenerais, porque não sabe mais a quem implorar apoio.

Somente um leitor excessivamente desatento poderia imaginar que os trechos acima são de autoria de Abreu e Lima. Mas a seu favor, porém, poderíamos argumentar que a desatenção fora propiciada pelo fato de os mesmos se situarem na abertura da conclusão de um trabalho cujo personagem maior distinguia-se, entre outras coisas, pela copiosa produção escrita. Não; os trechos acima não são retirados de um diário ou de uma caderneta de anotações do pernambucano que, com certeza, não hesitaria em concordar com algumas das observações ali contidas. No momento de redação daquelas notas por um observador sensível

- poucos meses antes do rompimento do Príncipe D. Pedro com as Cortes portuguesas, em 
setembro de 1822, configurando a Independência do Brasil -, Abreu e Lima não se encontrava em território português na América, e sim vivendo a dolorosa experiência do exílio.

Quem percorria, em 1822, o que denominamos hoje o Vale do Paraíba paulista era o naturalista francês Auguste de Saint-Hilaire. A passagem por Água Comprida e pela vila de Taubaté lhe permitia comparar e contrastar os sucessos da Revolução em sua terra com aqueles do Brasil, pondo em destaque, entre outras coisas, a figura do Rei e o seu destino, nas páginas de sua Segunda Viagem do Rio de Janeiro a Minas Gerais e São Paulo (SaintHilaire, 1975, p. 81). Comparação e contraste que, no essencial, revelavam os caminhos diversos que a crítica propiciada pelas idéias ilustradas aos fundamentos da sociedade do Antigo Regime tinham trilhado e permaneciam trilhando nas experiências francesa, de um lado, e ibérica, particularmente portuguesa, de outro. Caminhos que, em um primeiro momento, e de maneira extremamente simplificada para os propósitos que tenho em vista aqui, tinham conduzido ao pleno questionamento do poder real, simbolizado em seu guilhotinamento, no caso francês, e em sua preservação na experiência portuguesa, ainda que contido pelos limites impostos pelo constitucionalismo, particularmente após 1820, em ambos os lados do Atlântico. No ainda Reino do Brasil, sobretudo naquelas áreas distantes dos eventos ocorridos no Rio de Janeiro, os habitantes mostravam-se "absolutamente alheios às nossas teorias", observava o naturalista, sem revelar maior espanto talvez porque também constatasse que "o povo nada ganhou absolutamente com a mudança operada", razão por que professavam, "como outrora, o mesmo respeito pela autoridade, falam sempre do Rei como árbitro supremo de suas existências e da de seus filhos".

O Rei "como árbitro supremo de suas existências e da de seus filhos". Outra não fora, aos olhos de quase todos que passariam, desde então, a se identificar como brasileiros, a postura do Príncipe D. Pedro às margens do riacho do Ipiranga. Não era outra a razão, embora inúmeras outras lhe possam ser agregadas, por que Abreu e Lima destacaria sempre a figura e o papel do primeiro imperador, condições necessárias para a manutenção de uma ordem que quase sempre se confundia com a preservação da integridade de um território herdado da colonização portuguesa. Não era outra a expectativa que depositava no governo pessoal do segundo imperador, no momento em que encerrava a redação de Compêndio: "os futuros do 
Brasil... podem anunciar-se como muitos lisonjeiros debaixo do reinado do Segundo Pedro". Ali, como em todos os seus textos, a defesa da Monarquia, mas a defesa do Soberano, sobretudo, apresentava-se como a condição necessária para a constituição da Nação e dos brasileiros, nos marcos de um governo constitucional. Todavia, à herança ibérica somava-se, na formulação do autor de Bosquejo, a herança bolivariana, resgatada, por exemplo, na experiência do Congresso Constituinte da Bolívia em 1825, ocasião em que Bolívar defendera a presidência vitalícia para o país. Uma defesa intransigente do poder do Soberano que, como já foi salientado, provocaria acirrada oposição das demais forças políticas presentes, sobretudo, na Corte imperial, nos anos iniciais das Regências, contribuindo decisivamente para reforçar a caracterização do General de Bolívar como um caramuru $^{98}$.

Mas uma herança ibérica por quase todos os brasileiros partilhada, em maior um menor medida, conformando as opções políticas. No momento em que, em decorrência de um "acontecimento extraordinário" - a Abdicação - o "árbitro supremo de suas [dos brasileiros] existências e da de seus filhos" se tornava momentaneamente ausente, a Soberania deslocavase para a Nação, propiciando o que Justiniano José da Rocha denominou de "triunfo da Ação". Naquele momento, porém, ainda que presente, a possibilidade republicana ${ }^{99}$ não foi suficientemente forte para ameaçar a solução monárquica, ainda que esta assumisse diferentes formulações, matizadas pelo valor atribuído à liberdade política. Não posso afirmar se, pouco mais de uma década depois, Saint-Hilaire observando os rumos da política regencial confirmaria sua observação de que "são estes homens que, no Brasil, foram os cabeças da Revolução; não cuidavam senão em diminuir o poder do Rei, aumentando o próprio". A "luta da Reação" - ainda no dizer de Justiniano José da Rocha - e o seu "triunfo" permitiriam a consolidação monárquica, sob a direção saquarema. A "Maioridade" como acontecimento

\footnotetext{
${ }^{98}$ As disputas e lutas políticas sendo também disputas e lutas de representações provocavam deslocamentos sucessivos de imagens e atribuições de valores, em decorrência dos acontecimentos no Império do Brasil e no exterior, em particular na França. A chegada ao Rio de Janeiro da notícia da queda de Carlos X, em 1830, permitiria aos adversários de D. Pedro I associá-lo imediatamente ao "déspota" francês. Não poucos, ainda, associaram ao evento francês a deposição, pouco tempo antes, de Simon Bolívar, de modo a sublinhar o "triunfo da liberdade" que não tardaria a ocorrer também no Império do Brasil, conforme expresso pelo redator da Nova luz brasileira: "Bolívar, posto que comprado pela Santa Aliança, ainda não tinha consumado a sua traição vil, graças ao exaltamento patriótico do povo, e havia prestado bons serviços em outro tempo; Carlos X, pelo contrário, foi sempre um malvado de coroa, que roubou à França sua liberdade, sossego, riquezas. Ambos traidores, um por sedução, outro por gênio e condição real" (no. 81, 5 out. 1830).

${ }_{99}$ A respeito das propostas republicanas, cf. Silvia Carla Pereira de Brito Fonseca. A idéia de república no Império do Brasil: Rio de Janeiro e Pernambuco (1824-1834). Rio de Janeiro: UFRJ/IFCS, 2004 (tese de doutoramento) Mimeografado.
} 
assinalava simbolicamente o modo diverso como se efetivaria, desde então, a expansão para dentro, conformando os brasileiros que habitavam o Império do Brasil ao lado de outras "nações". O Compêndio da História do Brasil de Abreu e Lima aí buscava o seu lugar e razão. A polêmica que suscitaria no IHGB, em contraste com sua longa trajetória editorial, constitui uma evidência marcante de seu valor e papel. Para Abreu e Lima, porém, chegara o momento de retornar à sua pátria.

Chegando a Pernambuco, em 1844, Abreu e Lima logo se tornaria redator do Diário Novo, periódico do Partido da Praia. Quando mais uma vez as questões relativas à autonomia provincial combinaram-se às tensões de fundo social e racial, dando origem ao movimento Praieiro, lá estava presente Abreu e Lima, como se apenas estivesse esperando ser preso e enviado a Fernando de Noronha. Do encontro das idéias liberais com as idéias socialistas, que norteou os sonhos e as ações de alguns dos praieiros, resultaria $\mathbf{O}$ socialismo, um de seus textos mais conhecidos, ao menos nos dias que correm, escrito e publicado em 1855.

O polemista não esmorecia, lutando em favor de toda e qualquer emancipação. Nos anos 60, no decorrer do que a historiografia costuma designar como "o renascer liberal", Abreu e Lima voltaria a manifestar, ainda que de modo tardio, uma outra vertente da herança ibérica, acima referida, e que dizia respeito à conexão entre os valores de uma religiosidade cristã e a ação política. Fora ela que seguramente havia norteado, em larga medida, a defesa da extinção gradual do trabalho escravo por José Bonifácio de Andrada e Silva, na Memória que apresentara à Assembléia Constituinte em 1823, conforme já assinalado. Fora ela que havia norteado as críticas de Abreu e Lima à atuação da Igreja e do clero católicos no Império, presentes já nos primeiros números de Torre de Babel e retomados em Arca de Noé. Naqueles jornais, ele realizara uma crítica contundente à forma de nomeação dos bispos; aos projetos da comissão eclesiástica da Câmara dos Deputados; ao pagamento de taxas à Igreja; às regras que definiam quem poderia contrair matrimônio -, assim como defendera o que denominava "o progressivo da América", isto é, a supressão de conventos, como ocorrera na Europa, particularmente na Rússia. Todavia, tudo isto não significava o abandono do que identificava como os fundamentos religiosos e filosóficos do cristianismo como premissas para a construção de uma nação livre e de uma população menos heterogênea. 
Em 1866, sob o pseudônimo de "Cristão-novo", Abreu e Lima polemizou acirradamente com o Monsenhor Joaquim Pinto de Campos, através da imprensa, em defesa do casamento civil. ${ }^{100}$ Três anos mais tarde, quando Abreu e Lima faleceu, a polêmica ainda ali repercutia. Então, as autoridades religiosas da província negaram-lhe sepultura em cemitério católico e em território brasileiro. Como alternativa, o corpo de Abreu e Lima foi conduzido ao Cemitério dos Ingleses. Um outro exílio era imposto a José Inácio. Dele restaria o registro também na lápide de sua sepultura. ${ }^{101}$ Nos dias de hoje, o Movimento dos Trabalhadores Rurais Sem Terra, juntamente com a Prefeitura do Recife, reabriram a discussão a respeito da transferência dos restos mortais de Abreu e Lima para um cemitério em território brasileiro. O esforço para pôr fim a um último exílio retoma uma proposta do deputado pernambucano Paulo Cavalcanti, já falecido (MAZIN e STEDILE, 2006, p. 70).

O lugar daquele último exílio propiciaria muito rapidamente a inscrição de Abreu e Lima em uma última interseção: um lugar entre a memória e a história. Dele brotariam necrológios, biografias, estudos, poemas e outros tantos textos, esculpindo uma imagem. ${ }^{102}$ Falam todos tanto de Abreu e Lima quanto de seus autores, não obstante os diferentes propósitos que os movem.

Em 1876, por ocasião da publicação do Ano Biográfico Brasileiro, seguindo as regras retóricas comuns a esse tipo de texto, Joaquim Manuel de Macedo exaltava as qualidades do falecido escritor, não poupando elogios à sua atuação militar:

"É muito longa, e muito gloriosa a história da vida militar, de seus feitos marciais, e de seus brilhantes serviços na guerra de independência dessa parte da América". (MACEDO, 1876, p.425).

\footnotetext{
${ }^{100}$ Sobre a polêmica, consultar, entre outros, "Polêmica sobre as bíblias falsificadas. General Abreu e Lima com Cônego Pinto de Campos". In Alexei Bueno e George Ermakoff, orgs. Duelos no serpentário. Uma antologia da polêmica intelectual no Brasil, 1850-1950. Rio de Janeiro: G. Ermakoff Casa Editorial, 2005, p. 103-132. Ali estão reproduzidos vários excertos das cartas de Abreu e Lima, publicadas no Jornal do Recife, órgão do partido liberal, destacando os editores "a fabulosa verve e violência" que as distinguem; a respeito dos textos de Pinto de Campos, dizem os mesmos editores serem "de mínimo interesse literário". (p. 105)

101 "Aqui jaz / O cidadão brasileiro General / José Inácio de Abreu e Lima. / Propugnador esforçado da liberdade de / Consciência. / Faleceu em 8 de março de 1869. / Foi-lhe negada sepultura no Cemitério Público / pelo Bispo Dom Francisco Cardoso Aires./ Lembrança de seus parentes".

${ }^{102}$ Sobre a construção de imagens de personagens, embora com uma preocupação diversa, cf. Peter Burke. A construção do rei. Rio de Janeiro: Zahar, 1994.
} 
E prosseguia, pondo em evidência determinados acontecimentos que, por longo tempo, distinguiriam a memória que se forjava a respeito de Abreu e Lima:

\begin{abstract}
"Uma resolução do poder legislativo o fez entrar no gozo dos seus direitos de cidadão brasileiro, e lhe permitiu aquele do seu título de general, e de todas as honras, e condecorações que ganhara (...) na guerra da independência da América do Sul. Em 1833 ligou-se no Rio de Janeiro ao partido Caramuru ou Restaurador, e na imprensa periódica entrou em viva e ardente luta com Evaristo da Veiga; mas sua principal ocupação foi o estudo da história pátria” (MACEDO, 1876, p 426).
\end{abstract}

"O infeliz revolucionário" de 1817, que viveu "empresas militares arriscadíssimas", surgia, nas palavras de Macedo, general - embora sem adjetivações - e historiador, competência que lhe fora contestada pelos membros do IHGB.

Outros eram os tempos, e a morte contribuía, com certeza, para a construção de uma imagem amenizada e diversa das que até então haviam prevalecido. Todavia, esta também se diferenciaria das que estavam por ser produzidas.

A leitura dos escritos posteriores revela, salvo raras exceções, a tendência à exageração da figura do herói. Abreu e Lima teria sido o único brasileiro a lutar ao lado de Bolívar, Paez, Santander; a participar da "Era da abolição"; a estabelecer relações profundas com a América Latina. Nas narrativas produzidas a partir desse modelo, é possível perceber a intenção de provar como é inconsistente a imputação de que os brasileiros se distinguem "por virarmos as costas para os nossos vizinhos sul-americanos".

Após sua morte, além das homenagens de praxe no IHGB, Abreu e Lima só voltaria a ser lembrado no Brasil, em 1922, por ocasião das comemorações do centenário da Independência, e por um estrangeiro. Diego Carbonell, embaixador da Venezuela no Brasil, tomou a iniciativa de publicar, pela primeira vez, o Resumo Histórico da última ditadura 
do Libertador Simón Bolívar, acompanhado por biografia e notas de sua autoria. A Venezuela oferecia ao Brasil "a obra de um Prócer brasileiro, Abreu e Lima, que lutou na Venezuela durante a Guerra de Emancipação ao lado do Libertador e do general Paez" (CARBONELL, 1922).

Foi a partir do final dos anos 60 do século passado que a biografia do escritor, historiador, jornalista, general de Bolívar, herói sul-americano e revolucionário pernambucano começou a ser escrita por brasileiros, em sua maioria pernambucanos.

Argeu Guimarães e Barbosa Lima Sobrinho redigiram prefácios e introduções, além de terem proferido conferências, relacionadas tanto às comemorações quanto à publicação da biografia de Bolívar e à reedição de $\mathbf{O}$ socialismo, respectivamente.

No "Prefácio" a O Socialismo, Barbosa Lima Sobrinho recorda que, em 1969, Elbano Provenzano Heredia, embaixador da Venezuela, promovera "no Instituto Histórico Brasileiro uma homenagem, em comemoração do centenário da morte de Abreu e Lima da qual tive a honra de ser o orador". Relembra ter tentado à época, sem êxito, divulgar a conferência em Pernambuco, e conclui:

\footnotetext{
"Parece que ele (Abreu e Lima) andava incluído na lista dos subversivos, não obstante sua categoria de herói continental, e de combatente de batalhas cruentas, nas lutas pela libertação da América” (LIMA SOBRINHO, 1979, p. 14).
}

Tal qual outros biógrafos, Barbosa Lima Sobrinho destaca o interesse da Venezuela pelo revolucionário brasileiro, e sublinha que ainda em outubro de 1868 fora o cônsul da Argentina no Recife quem divulgara na Revista de Buenos Aires, a carta que Abreu e Lima escrevera a Paez no mesmo ano. ${ }^{103}$

\footnotetext{
${ }^{103} \mathrm{O}$ texto integral da carta foi publicado em "Biografias de Aspuría", no $3^{\circ}$ volume da revista Novo Mundo, que a considera "um testemunho de recordações de meio século" (cf. Diego Carbonnel, op. cit.)
} 
Se a imagem do "pernambucano, brasileiro injustamente esquecido" aparece mais fortemente nos prefácios e nas biografias, também é possível encontrá-la nos verbetes de dicionários biográficos publicados no mesmo período.

José Bernardes e Vamireh Chacon publicaram suas biografias de Abreu e Lima em 1978 e 1983, respectivamente. Os títulos das biografias de tão expressivos dizem mais do que qualquer comentário que possa fazer: Abreu e Lima, herói sul americano e Abreu e Lima, general de Bolívar.

Ainda assim, o esquecimento permanece, ao menos parcialmente. O Compêndio e até mesmo a polêmica com Francisco Adolfo de Varnhagen não são sequer mencionados em algumas obras, como em Velho Sobrinho (1937), em Sacramento Blake (1898), em Ronaldo Vainfas (2002) e no próprio Barbosa Lima Sobrinho (1979).

Moacir Werneck de Castro em O libertador. A vida de Simón Bolívar dedica cerca de três páginas a um dos 'bolivarianos' que merece destaque especial, ou seja, Abreu e Lima, e ao se referir a seu retorno ao Brasil destaca apenas que "continuou combatente. Armou polêmicas com Evaristo da Veiga (...) e Varnhagen" (CASTRO, 1989, p. 164). Por sua vez, o venezuelano Diego Carbonell, além de fazer referência à polêmica com Varnhagen, torna expressa suas concordâncias com Abreu e Lima.

Pereira da Costa em seu famoso Dicionário de pernambucanos ilustres, obra referencial para a maioria dos autores que escreveram sobre Abreu e Lima, não esqueceu a polêmica historiográfica, mas sua lembrança parece ter sido insuficiente para despertar em outros autores preocupação pelo tema.

Em Teoria da História do Brasil, José Honório Rodrigues analisa a proposta de periodização para a História do Brasil apresentada em Compêndio, e conclui que mesmo sendo merecedora de críticas severas, ela constitui "a primeira tentativa de um agrupamento de fatos por período" (RODRIGUES, 1957, p.158). Faz referência também à polêmica com Varnhagen, destacando ter sido uma das mais violentas da historiografia brasileira. E vai 
além: ao transcrever trechos de Bosquejo tem a intenção de ressaltar as idéias do autor sobre a escravidão:

Ao escrever sobre a escravidão negra no Brasil e sua necessidade naquela fase de nossa evolução, esclarece que quando emprega as denominações de 'branco', 'mulato' ou 'negro' estas devem ser entendidas apenas como acidentais, para denotar uma classe, 'pois ninguém deverá persuadir-se que possamos usar de uma expressão com o desígnio de ofender a pessoa alguma, nem para menoscabar a dignidade de uma porção de homens que, em nosso conceito, têm tanto direito à nossa benevolência como outra qualquer classe ou indivíduo'. Diz Abreu e Lima que logo à primeira vista se nota que a população brasileira está dividida em duas partes iguais, isto é, pessoas livres e pessoas escravas, que de certo modo não apresentam grande afinidade, as quais, por sua vez, se dividem em quatro grandes famílias distintas tão opostas e inimigas umas das outras como as duas grandes seções entre si (RODRIGUES, 1957, p.214).

Em resumo, quando lembrado, o historiador José Inácio de Abreu e Lima o é por ter motivado a mais famosa polêmica da historiografia brasileira, no século retrasado. Todavia, o Compêndio da História do Brasil, isto é, o motivo da polêmica ou é sumariamente suprimido ou merece poucas e inexpressivas linhas.

Mesmo seus biógrafos Bernardes e Chacon se restringem a informar sobre a interdição da obra e sobre a polêmica com Varnhagen, sendo que o segundo o faz mais detalhadamente que o primeiro.

Em tese de doutoramento em História da Educação, Arlette Medeiros Gasparello estudou o ensino secundário no Império, e mais especificamente o ensino da disciplina "História" no Colégio Pedro II, da metade do século XIX ao início do XX. Nela destaca as contribuições de Abreu e Lima e Bellegarde, no capítulo intitulado "A história patriótica". (GASPARELLO,2004, p.77-112). 
Para o historiador José Murilo de Carvalho, "talvez o exemplo mais vivo da percepção da monarquia como garantia da unidade do País seja o do General Abreu e Lima" (CARVALHO, 1998, p. 161).

Assim, talvez não constitua um despropósito pôr em destaque uma passagem de Gilberto Freyre em "Tipos sócio-antropológicos no romance brasileiro: sua projeção como símbolos além dos seus tempos históricos”. Ali, questiona-se o autor pernambucano:

\begin{abstract}
"Não serão os romancistas ou novelistas, como aliás, os dramaturgos, os compositores, os filósofos ou os pensadores, os ensaístas, os sociólogos de certo tipo, criadores, como os poetas, os artistas plásticos, os místicos do tipo da católica Santa Teresa e do batista Bunyan, de formas, de categorias, de tipos e, principalmente, de símbolos - menos símbolos declarados que em potencial: germens de futuros símbolos - através dos quais a vida, o passado, a chamada natureza humana, e, dentro dela, o chamado caráter nacional de uma sociedade, projetando-se sobre o seu próprio futuro, se tornam perceptíveis, sensíveis e até, em alguns casos, compreensíveis e inteligíveis? Não haverá sempre numa novela, ou num romance, que seja, senão literalmente válido, sociologicamente significativo, símbolos em potencial ou tipos potencialmente simbólicos - e além de assim présimbólicos, socialmente expressivos?"
\end{abstract}

Prosseguindo em sua reflexão, Freyre enfatiza o fato de Cervantes ter criado dois personagens, D. Quixote e Sancho Pança,

(...) que sociológica, ou psicossocialmente, só podem ser compreendidos em relação não apenas com a Espanha (espaço) como, de modo específico, com o declínio (tempo) das práticas de cavalaria andante na Espanha. Isto é, em relação com específicas formas sociais. Esteticamente, entretanto, ao mesmo tempo que psicossocialmente, podem ser abstraídos dos conteúdos específicos dessas formas para serem vistos, contemplados, desfrutados, pelo que neles é simbólico. Simbólico de dois tipos universalíssimos de condição humana, com formas antropológicas também simbolicamente universais e 
não apenas espanholas: a associação da magreza como característico psicossomático, ao heroísmo, ao idealismo, ao altruísmo, ao misticismo, à audácia, à criatividade desdobrada por vezes em ação ou conduta romântica; e a associação da gordura à prudência, à cautela, ao senso comum, ao realismo, ao sentido prosaicamente pragmático, quer da existência, quer da conduta.

$\mathrm{Na}$ grande novela - ou romance - de Cervantes os dois contrários se mantêm como estáticos, do princípio ao fim da narrativa (...).O tempo quase não os altera. O que vem sucedendo também com personagens apresentados, desde que esse modelo genial surgiu em literatura, por outros romancistas e criadores ou fixadores de tipos simbólicos de homem ou de mulher. Inclusive no romance brasileiro: em vários dos livros desse gênero de autores brasileiros os personagens são antes estáticos do que dinâmicos em seus característicos de tipos antropológicos mais potencialmente simbólicos do seu meio e de sua época, que de uma categoria pan-humana, como se estáticos fossem também os espaços e os tempos sociais dentro dos quais eles se realizam como heróis, como vilões: fixos, imutáveis, permanentes.

E quase conclui:

(...) A verdade, porém, é que nem Pernambuco, nem Minas, nem a Bahia - a chamada Virgínia brasileira - tiveram durante a época castiçamente chamada patriarcal, quem, à maneira de um Machado de Assis, retratasse, analisasse ou criticasse em romances brasileiramente regionais a doçura lenta do seu viver nas casas-grandes do Recôncavo ou nos sobrados de Salvador refletidas sobre expressões psicológicas vindas, nesses meios, de dentro para fora. Nem em Pernambuco surgiu, na mesma época, um José de Alencar que romantizasse em obras literárias, o heroísmo de um Pedro Ivo ou a bravura de um Abreu e Lima: dois longilíneos mistos - pelo que deles se sabe - de dionisíacos e de apolíneos. (FREYRE, 1979, p. 60-66). 
Ao constatar a inexistência de um romance brasileiramente regional que retratasse e analisasse a vida de homens e mulheres potencialmente simbólicos de seu meio e de sua época, Freire seleciona alguns exemplos, e dentre eles aponta um bravo e longilíneo herói pernambucano - Abreu e Lima.

Não há romances, mas são em número significativo as memórias, biografias, artigos e outras referências escritas por autores que o enaltecem com maior ou menor vigor, do final do século XIX até os dias atuais. Se em momento anterior sublinhei semelhanças, torno a fazê-lo. Os textos que compõem a bibliografia sobre Abreu e Lima guardam uma outra similitude referente ao diálogo entre dois tempos: o presente de cada um dos autores, de onde eles falam e como falam, e o tempo de Abreu e Lima. É como se houvesse uma teia invisível a aprisionar as análises sobre sua vida. Observações e críticas que se contradizem surgem ao longo de um mesmo texto, o revolucionário e republicano se tornando um caramuru; o conservador defendendo a alternativa socialista, entre outros exemplos. Não por outra razão talvez tenha encontrado, de modo recorrente, nos diferentes dicionários bio-bibliográficos a correlação entre as idades da vida e as características conflitantes do personagem, o que se apresentava como uma solução para o autor do verbete.

Ainda ignorado por muitos nos dias de hoje, aí incluídos os historiadores, Abreu e Lima permanece povoando o imaginário dos pernambucanos, do homem comum aos poetas, dos cientistas sociais aos políticos.

Lá está ele, na poesia de João Cabral de Mello Neto; é possível capturá-lo na internet, nos dados sobre o município que leva seu nome ou em uma poesia de José Almino.

Evocação da Avenida Norte

José Almino de Alencar

Não tenho pais, nem irmãos, parentes ou amigos:

estou só na Avenida Norte.

Me encanta a Avenida Norte. 
Me encanta seu nome cardinal,

a minúscula Assembléia de Deus,

o homem cotó,

a gente feinha, a gente feiazinha.

Irei para o Arruda, para Beberibe,

ou ficarei na Encruzilhada.

Estarei sempre na Avenida Norte.

Eu quero a Avenida Norte, como a mulher que passa.

Para trás os ingleses cobertos de tapuru,

Na sombra das palmeiras do cemitério dos ingleses;

Abreu e Lima morto e enterrado.

Não quero.

Não quero:

as jaqueiras da Casa Forte,

o remanso do rio do Poço da Panela,

tampouco.

Eu quero a Avenida Norte.

Tenho a pedra de Zalagh

Mais argila do Saïs:

Breve serei muito menos.

Terei a Avenida Norte. ${ }^{104}$

De modo quase inevitável, retorno ao ponto de partida - "José Inácio de Abreu e Lima viveu várias vidas em seus setenta e cinco anos de existência" - para poder acrescentar, no momento de concluir - e outras tantas, inventadas e reinventadas pelas pesquisas e imaginação daqueles que dele se ocuparam e por ele se deixaram seduzir, positiva ou

${ }^{104}$ www.casaruibarbosa.gov.br 
negativamente. Neste trabalho, Abreu e Lima parece, por vezes, viver uma a mais; mas não é bem assim!

Desta "quase outra vida", as páginas de um compêndio não contêm um "resumo do mais substancial", embora as múltiplas vidas vividas por seu autor ali não possam deixar de estar presentes. Produzido em um momento que se distinguia por uma expansão singular uma expansão para dentro -, a qual forjava uma Nação que ansiava por participar de uma comunidade de "Nações civilizadas" e optara por conviver com outras "nações" no interior de um mesmo território, o Compêndio da História do Brasil tinha entre suas intenções principais ser uma espécie de espelho no qual os brasileiros pudessem se reconhecer. E isto distingue o seu lugar entre múltiplas interseções. Todavia, reconhecer o valor de uma obra muitas vezes esquecida ou silenciada não significa atribuir-lhe um lugar de destaque na compreensão de uma vida. Afinal, aquele que alinhavou suas inúmeras vidas com os fios de uma deliberação consciente, não escolhera viver exclusivamente para redigir um compêndio, mesmo que pudesse adivinhar que algum dia seria ele objeto de uma tese de doutoramento. 


\section{ANEXOS}

ANEXO I - RUA DIREITA - GRAVURA DE JOÃO MAURÍCIO RUGENDAS 


\title{
ANEXO II - RESUMO DA HISTÓRIA DO BRASIL DE BELLEGARD
}

\author{
Resumo de História do Brasil \\ até 1828 \\ Traduzido de Denis correto e aumentado \\ por \\ H. L. de Niemeyer Bellegard \\ Rio de Janeiro \\ na Tipografia Gueffier E. C. \\ 1831
}

\begin{abstract}
Advertência
O original desta obra é por vezes inexato; nós trabalhamos para que a tradução o não fosse. Todas as passagens que aqui se acharem nas primeiras época, estranhas ao Resumo francês, estão em D. De Goy, Rocha Pita, Madre de Deus, Aires Casal, Lery ou Southey.

Quanto a parte contemporânea que nos diz respeito, limitamo-nos a pura e ingênua exposição dos fatos, por assim o exigir o plano desta epítome.
\end{abstract}




\section{ÍNDICE}

$1^{\mathrm{a}}$ Época - O Brasil antes da conquista.

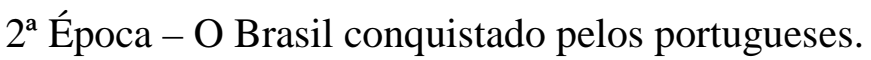

2.1 - Divisão do Brasil em capitanias.

2.3 - Povoação do Espírito Santo.

2.4 - Povoação de Pernambuco.

2.5 - Povoação da Bahia.

2.6 - Tentativa dos franceses para se estabelecerem no Brasil.

2.7 - Povoação de São Paulo.

2.8 - Expulsão dos franceses.

2.9 - Povoação do Rio de Janeiro

2.10 - Divisão do Brasil em dois governos separados.

2.11 - O Brasil volta ao regime de um só governo.

2.12 - Povoação da Paraíba.

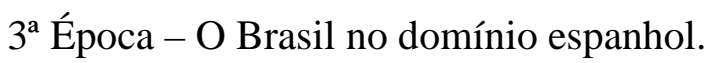

3.1 - Minas de Prata.

3.2 - Povoação de Sergipe

3.3 - Os ingleses acometem o Brasil.

3.4 - Povoação do Rio Grande do Norte.

3.5 - Incursões no interior.

3.6 - Povoação do Ceará.

3.7 - Nova expedição francesa.

3.8 - Povoação do Maranhão.

3.9 - Povoação do Pará.

3.10 - Os holandeses atacam o Brasil.

3.11 - A conduta dos colonos para com os indígenas.

3.12 - Segunda invasão e estabelecimento dos holandeses.

3.13 - Viagem pelo Amazonas.

3.14 - O Brasil é governado pelos Vice-Reis.

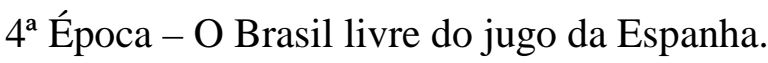

4.1 - Insurreição em São Vicente. 
4.2 - Expulsão dos holandeses.

4.3 - O Brasil recebe o título de Principado.

4.4 - Povoação de Santa Catarina.

4.5 - Rasgo de valor.

4.6 - Povoação de Alagoas.

4.7 - Fundação da Colônia de Sacramento.

4.8 - Minas de ouro.

4.9 - Povoação de Minas.

4.10 - Negros de Palmares.

4.11 - Outras expedições francesas.

4.12 - Decadência do Norte.

4.13 - Povoação do Piauí.

4.14 - Povoação de Mato Grosso.

4.15 - Povoação de Goiás.

4.16 - Minas de diamantes.

4.17 - Povoação do Rio Grande do Sul.

4.18 - Guerras de limites.

4.19 - A capital do Brasil passa para o Rio de Janeiro.

4.20 - Melhoramentos no Brasil.

4.21 - Os espanhóis tomam Santa Catarina.

4.22 - Limites definidos.

4.23 - Intento revolucionário em Minas.

4.24 - Guerra com Buenos Aires.

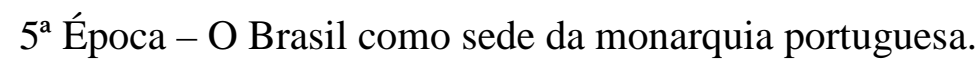

5.1 - Liberdade de comércio.

5.2 - Invasão de Caiena.

5.3 - Patriótica administração.

5.4 - O Brasil elevado a Reino.

5.5 - A campanha do Sul.

5.6 - A revolução em Pernambuco.

5.7 - O casamento do príncipe real.

5.8 - Aclamação do Rei D. João VI. 
5.9 - Segunda campanha do Sul.

5.10 - Nova Constituição política.

5.11 - Reunião eleitoral no Rio de janeiro.

5.12 - O regresso de D. João VI.

5.13 - O Príncipe D. Pedro fica Regente no Brasil.

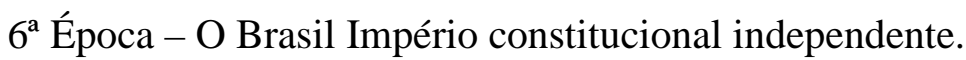

6.1 - Reunião da Assembléia constituinte.

6.2 - Movimentos em diferentes Províncias.

6.3 - Incorporação de Montevidéu ao Brasil.

6.4 - Dissolução da Constituinte.

6.5 - Constituição oferecida pelo Imperador.

6.6 - Segunda revolução em Pernambuco.

6.7 - Atentado na Bahia.

6.8 - Reconhecimento da independência.

6.9 - Nascimento do príncipe imperial D. Pedro.

6.10 - O Imperador dá Constituição a Portugal e abdica a Coroa daquele Reino.

6.11 - Terceiro período de Campanha do Sul.

6.13 - Matança no Rio de Janeiro.

6.14 - O fim da Campanha do Sul e separação de Montevidéu. 


\section{CONCLUSÃO}

Aqui o fim de nossa tarefa; feliz se nossos jovens compatriotas acharem neste livro auxílio a seus primeiros estudos, único incentivo que a tal publicação nos animou. A pena mais hábeis, que não a nossa de ruim estilo e de pior critério, pertence a arrazoada narrativa da completa história brasileira; (praza aos céus que) em venturoso porvir lhes ministre dourada matéria (praza ao céu que) o saber, o patriotismo dos Poderes a quem cabe o grave encargo de promover o bem da Pátria, consigam extirpar fatais rivalidades. Sirvam os estranhos países de exemplo ao nosso; embora se objete com a diferença de localidade; o gênio das Nações depende mais das leis que as regem, do que da atmosfera que as cobre; o Grego da natureza é hoje o mesmo que o dos séculos de ouro, mas os vícios do governo tem privado Atenas de novos Péricles e novos Fídias.

N. B. Nem em uma só palavra do nosso autógrafo tocamos, depois do memorável dia 7 de abril de 1831; julgamos ter escrito a VERDADE; e a verdade é uma, e eternamente imutável. 


\section{ANEXO III - IMPERIAL COLÉGIO DE PEDRO II}

\section{A) PERGUNTAS PARA EXAMES DE HISTÓRIA DO BRASIL DO ANO DE 1849}

1. Descobrimento do Brasil: primeiros exploradores.

2. Divisão do Brasil em capitanias.

3. Estado do Brasil. Tomé de Souza e Duarte da Costa. Jesuítas - Nóbrega e Anchieta.

4. Influência dos jesuítas no Brasil, sua expulsão.

5. Continuação.

6. Invasão francesa no Rio de Janeiro de Villegaignon.

7. Expulsão dos franceses. Estácio de Sá.

8. Estabelecimento dos franceses no Maranhão.

9. Du Clerc, e Dugué-Trouin.

10. D. Sebastião - Domínio espanhol.

11. Incursões inglesas. Cavandish e Lancaster.

12. Invasão holandesa no Brasil.

13. Guerra holandesa. Desde a invasão até a expedição de Canefelt.

14. Desde a chegada de Oquendo até a retirada de Matias de Albuquerque.

15. D Luiz de Roxas. Bagnuolo até a evacuação de Sergipe.

16. O conde Mauricio de Nassau até a invasão da Bahia.

17. Revolução de 1640 em Portugal. - Amador Bueno - Trégua com os holandeses.

18. Expedição de João Cornelles: expulsão dos holandeses do Maranhão.

19. Retirada de Maurício de Nassau - Viera. Derrota de Huss e Blaar.

20. Primeira e segunda batalhas dos Guararapes.

21. Chegada de Barreto: os portugueses entram no Recife. Efeitos da conquista.

22. Vidal de Negreiros e seu sucessor.

23. Revolta chamada dos mascates.

24. Tentativa de 1817.

25. Salvador Correia no governo do Rio de Janeiro.

26. Conspiração de Beckman.

27. Descoberta das minas no Brasil.

28. Continuação. 
29. Projeto de revolução em Minas - José da Silva Xavier.

30. Limites do Brasil.

31. Continuação.

32. Colônia do Sacramento.

33. Ataque de Salcedo.

34. Demarcação dos limites - Gomes Freire e Valdelirios.

35. Campanha de Zeballos até a paz de Madrid.

36. Conde Florida Blanca. Zeballos até a paz de Madrid.

37. Vinda do Sr. D. JoãoVI - Acontecimentos até o ano de 1815.

38. Acontecimentos de 1815 até 1821.

39. Regência do Sr. D. Pedro. Aclamação da Independência.

40. Acontecimentos nas Províncias do Brasil até que aderiram à Independência. 
B) PROGRAMAS DE EXAME

\begin{tabular}{|c|c|c|}
\hline $\begin{array}{l}\text { História do Brasil } \\
1850-7^{\circ} \text { ano }\end{array}$ & $\begin{array}{c}\text { História do Brasil } \\
1851-7^{\circ} \text { ano }\end{array}$ & $\begin{array}{c}\text { Corografia e História do } \\
\text { Brasil }-1858-4^{\circ} \text { ano }\end{array}$ \\
\hline $\begin{array}{l}\text { 1. Descobrimento do Brasil: } \\
\text { primeiros exploradores. }\end{array}$ & 1. Descobrimento do Brasil & $\begin{array}{l}\text { 1. Considerações gerais sobre } \\
\text { as viagens e descobrimentos } \\
\text { dos portugueses: o infante } \\
\text { D. Henrique - Bartolomeu } \\
\text { Dias - Colombo - D. João } \\
\text { II de Portugal - D.Manuel - } \\
\text { Vasco da Gama. }\end{array}$ \\
\hline $\begin{array}{l}\text { 2. Divisão do Brasil em } \\
\text { capitanias. }\end{array}$ & 2. Primeiros exploradores. & $\begin{array}{l}\text { 2. Descobrimento do Brasil: } \\
\text { seus primeiros } \\
\text { exploradores. - Causas das } \\
\text { indiferenças dos } \\
\text { portugueses pelo } \\
\text { descobrimento de Cabral. } \\
\text { Ainda D. Manuel. } \\
\end{array}$ \\
\hline $\begin{array}{l}\text { 3. Estado do Brasil - Tomé de } \\
\text { Souza e Duarte da Costa. } \\
\text { Jesuítas - Nóbrega e } \\
\text { Anchieta. }\end{array}$ & $\begin{array}{l}\text { 3. Divisão do Brasil em } \\
\text { capitanias. }\end{array}$ & $\begin{array}{l}\text { 3. O Brasil antes do } \\
\text { descobrimento. Os } \\
\text { indígenas, seu caráter, usos } \\
\text { e costumes: descrição geral } \\
\text { da região. }\end{array}$ \\
\hline $\begin{array}{l}\text { 4. Invasão francesa no Rio de } \\
\text { Janeiro, Villegaignon. }\end{array}$ & 4. Caramuru. & $\begin{array}{l}\text { 4. D. João III: seu sistema de } \\
\text { colonização no Brasil, } \\
\text { capitanias hereditárias de S. } \\
\text { Vicente, Santo Amaro, } \\
\text { Itamaracá, Paraíba do Sul } \\
\text { ou S. Tomé, Espírito Santo, } \\
\text { Ilhéus, Porto Seguro e } \\
\text { Bahia de Todos os Santos: } \\
\text { expedições desgraçadas de } \\
\text { Luís Melo e Aires da } \\
\text { Cunha: a capitania do } \\
\text { Maranhão concedida ao } \\
\text { historiador João de Barros. }\end{array}$ \\
\hline $\begin{array}{l}\text { 5. Expulsão dos franceses do } \\
\text { Rio de Janeiro. Estácio de } \\
\text { Sá. }\end{array}$ & $\begin{array}{l}\text { 5. Tomé de Souza. Chegada } \\
\text { dos jesuítas ao Brasil. }\end{array}$ & $\begin{array}{l}\text { 5. Caramuru - Francisco } \\
\text { Pereira Coutinho: primeiras } \\
\text { hostilidades entre } \\
\text { tupinambás e os } \\
\text { portugueses: expulsão e } \\
\text { morte de Coutinho. }\end{array}$ \\
\hline $\begin{array}{l}\text { 6. Estabelecimento. La } \\
\text { Ravardière. Expulsão por } \\
\text { André de Moura. }\end{array}$ & $\begin{array}{l}\text { 6. Duarte da Costa. Nóbrega e } \\
\text { Anchieta. }\end{array}$ & $\begin{array}{l}\text { 6. Inconvenientes do sistema } \\
\text { de colonização empregado; } \\
\text { chegada de Tomé de Souza } \\
1^{\circ} \text { governador geral; } \\
\text { fundação da cidade de S. } \\
\text { Salvador: organização } \\
\text { política da colônia. }\end{array}$ \\
\hline
\end{tabular}




\begin{tabular}{|c|c|c|}
\hline 7. Du Clerc e Duguay Trouin. & 7. Villegaignon. & $\begin{array}{l}\text { 7. Influência da religião no } \\
\text { Brasil: estado do clero da } \\
\text { colônia: Nóbrega }-2^{\circ} \\
\text { governador geral - Duarte } \\
\text { da Costa - Anchieta - } \\
\text { Fundação da colônia de } \\
\text { Piratininga, depois S. Paulo. } \\
\text { - conflitos entre os jesuítas } \\
\text { e os povoadores. - o bispo } \\
\text { Sardinha: sua morte. }\end{array}$ \\
\hline $\begin{array}{l}\text { 8. D. Sebastião - Domínio } \\
\text { espanhol. }\end{array}$ & $\begin{array}{l}\text { 8. Expulsão dos franceses do } \\
\text { Rio de Janeiro. Estácio de } \\
\text { Sá. }\end{array}$ & $\begin{array}{l}\text { 8. Tentativas dos franceses } \\
\text { para se estabelecerem no } \\
\text { Brasil: Rio de Janeiro: } \\
\text { Villegaignon, Duclerc e } \\
\text { Duguay Trouin, Maranhão: } \\
\text { Rifault e La Ravardière. }\end{array}$ \\
\hline $\begin{array}{l}\text { 9. Incursões inglesas } \\
\text { Cavendish e Lancaster. }\end{array}$ & $\begin{array}{l}\text { 9. Men de Sá - Confederação } \\
\text { dos tamoios. }\end{array}$ & $\begin{array}{l}\text { 9. Men de Sá, } 3^{\circ} \text { governador } \\
\text { Geral: fundação da cidade } \\
\text { de S. Sebastião do Rio de } \\
\text { Janeiro: confederação dos } \\
\text { indígenas contra os } \\
\text { portugueses. }\end{array}$ \\
\hline $\begin{array}{l}\text { 10. Invasão holandesa na Bahia } \\
\text { - Hans Van Dort. Expulsão } \\
\text { - D. Fradique de Toledo. }\end{array}$ & $\begin{array}{l}\text { 10. Salvador Correa. Fundação } \\
\text { da cidade do Rio de Janeiro. }\end{array}$ & $\begin{array}{l}\text { 10. Divisão do Brasil em } 2 \\
\text { governos: Salema: } \\
\text { destruição dos tamoios - } \\
\text { transmigração dos } \\
\text { tupinambás. - A cruz e a } \\
\text { espada. - A catequese e a } \\
\text { distribuição. - } \\
\text { Inconvenientes da divisão } \\
\text { do governo do Brasil: Luiz } \\
\text { Brito único governador. }\end{array}$ \\
\hline $\begin{array}{l}\text { 11. Guerra holandesa. Desde a } \\
\text { invasão até a expedição de } \\
\text { Caneflet a Itamaracá. }\end{array}$ & $\begin{array}{l}\text { 11. Divisão do Brasil em dois } \\
\text { governos. Antônio de } \\
\text { Salema. Os tupinambás. }\end{array}$ & $\begin{array}{l}\text { 11. D. Sebastião exploração } \\
\text { desastrosa da África; o } \\
\text { cardeal D. Henrique: Filipe } \\
\text { II: domínio espanhol: estado } \\
\text { do Brasil na época em que } \\
\text { Portugal passou para o } \\
\text { domínio de Espanha. }\end{array}$ \\
\hline $\begin{array}{l}\text { 12. Desde a chegada de } \\
\text { Oquendo até a expedição de } \\
\text { Caneflet a Itamaracá. }\end{array}$ & $\begin{array}{l}\text { 12. Domínio espanhol - } \\
\text { Incursões inglesas. }\end{array}$ & \\
\hline $\begin{array}{l}\text { 13. D. Luiz de Roxas - } \\
\text { Bagnuolo até a evacuação } \\
\text { de Sergipe. }\end{array}$ & $\begin{array}{l}\text { 13. Os franceses no Maranhão e } \\
\text { a sua expulsão por } \\
\text { Alexandre de Moura. }\end{array}$ & \\
\hline $\begin{array}{l}\text { 14. O conde de M. De Nassau } \\
\text { até a invasão da Bahia. }\end{array}$ & $\begin{array}{l}\text { 14. Primeira invasão } \\
\text { holandesa. Hans Van Dort } \\
\text { em S. Salvador. }\end{array}$ & \\
\hline $\begin{array}{l}\text { 15. Revolução de } 1640 \text { em } \\
\text { Portugal - Amador Bueno - } \\
\text { Trégua aos holandeses. }\end{array}$ & 15. D. Fradique de Toledo. & \\
\hline
\end{tabular}




\begin{tabular}{|c|c|c|}
\hline $\begin{array}{l}\text { 16. Matias de Albuquerque em } \\
\text { Pernambuco. Tomada de } \\
\text { Olinda. Vieira. }\end{array}$ & $\begin{array}{l}\text { 16. Expedição de João } \\
\text { Cornelles: expedição dos } \\
\text { holandeses ao Maranhão. }\end{array}$ & \\
\hline $\begin{array}{l}\text { 17. Campo Real do Bom Jesus- } \\
\text { Escaramuças }\end{array}$ & 17. Conspiração de Beckman. & \\
\hline $\begin{array}{l}\text { 18. Reitirada de M. De Nassau } \\
\text { - Vieira - Derrota de Hus e } \\
\text { Blaar. }\end{array}$ & $\begin{array}{l}\text { 18. D. Antônio de Oquendo. } \\
\text { Combate naval. Bagnuolo. }\end{array}$ & \\
\hline $\begin{array}{l}\text { 19. Schoppe volta ao Brasil. } \\
\text { Primeira batalha de } \\
\text { Guararapes. }\end{array}$ & $\begin{array}{l}\text { 19. Domingos Fernandes. } \\
\text { Calabar }\end{array}$ & \\
\hline $\begin{array}{l}\text { 20. Segunda batalha dos } \\
\text { Guararapes - Os } \\
\text { portugueses entram em } \\
\text { Recife - Efeitos da } \\
\text { conquista. }\end{array}$ & $\begin{array}{l}\text { 20. Sigismundo Van Schopp } \\
\text { até a Conquista da Paraíba. }\end{array}$ & \\
\hline $\begin{array}{l}\text { 21. Vidal de Negreiros e seus } \\
\text { sucessores no governo de } \\
\text { Pernambuco. }\end{array}$ & $\begin{array}{l}\text { 21. Matias de Albuquerque } \\
\text { desde a perda de Nazaré até } \\
\text { a retirada para as Alagoas. }\end{array}$ & \\
\hline $\begin{array}{l}\text { 22. Revolta chamada dos } \\
\text { mascates. }\end{array}$ & $\begin{array}{l}\text { 22. Revolta chamada dos } \\
\text { mascates. }\end{array}$ & \\
\hline $\begin{array}{l}\text { 23. Bagnuolo toma o comando. } \\
\text { Devastações. Segunda } \\
\text { emigração dos habitantes de } \\
\text { Pernambuco. }\end{array}$ & $\begin{array}{l}\text { 23. Salvador Correia no } \\
\text { governo do Rio de Janeiro. }\end{array}$ & \\
\hline $\begin{array}{l}\text { 24. Descoberta das minas do } \\
\text { Brasil. Seus efeitos. }\end{array}$ & $\begin{array}{l}\text { 24. Maurício de Nassau. Ataque } \\
\text { a Porto Calvo. }\end{array}$ & \\
\hline $\begin{array}{l}\text { 25. Projeto de revolução em } \\
\text { Minas - Joaquim José da } \\
\text { Silva Xavier. }\end{array}$ & $\begin{array}{l}\text { 25. Bagnuolo até a evacuação } \\
\text { de Sergipe. }\end{array}$ & \\
\hline $\begin{array}{l}\text { 26. Colônia do Sacramento. } \\
\text { Desde a sua fundação até a } \\
\text { sua reconstrução. }\end{array}$ & $\begin{array}{l}\text { 26. Pedro da Silva. Ataque de S. } \\
\text { Salvador }\end{array}$ & \\
\hline 27. Ataque de Salcedo. & $\begin{array}{l}\text { 27. Conde da Torre. Marquês de } \\
\text { Montalvão, } 1^{\circ} \text { vice-rei do } \\
\text { Brasil. }\end{array}$ & \\
\hline $\begin{array}{l}\text { 28. Demarcação de limites } \\
\text { 1750. } 1^{\mathrm{a}} \text { campanha de } \\
\text { Gomes Freire. }\end{array}$ & $\begin{array}{l}\text { 28. Revolução de } 1640 \text { em } \\
\text { Portugal. Tréguas com os } \\
\text { holandeses. }\end{array}$ & \\
\hline $\begin{array}{l}\text { 29. Segunda campanha de } \\
\text { Gomes Freire. Anulação do } \\
\text { tratado de } 1790 \text {. }\end{array}$ & $\begin{array}{l}\text { 29. Retirada de Maurício de } \\
\text { Nassau. Seus efeitos. }\end{array}$ & \\
\hline $\begin{array}{l}\text { 30. Campanha de Ceballos até a } \\
\text { Paz de Paris. }\end{array}$ & $\begin{array}{l}\text { 30. Vieira. Conjuração em } \\
\text { Pernambuco. }\end{array}$ & \\
\hline $\begin{array}{l}\text { 31. Conde Florida Blanca. } \\
\text { Ceballos até a paz de } \\
\text { Madrid. }\end{array}$ & $\begin{array}{l}\text { 31. Guerra dos Independentes } \\
\text { até a chegada de Schopp. }\end{array}$ & \\
\hline $\begin{array}{l}\text { 32. Influência dos jesuítas no } \\
\text { Brasil, sua expulsão. }\end{array}$ & 32. $1^{\mathrm{a}}$ batalha dos Guararapes. & \\
\hline $\begin{array}{l}\text { 33. Vinda de D. João VI - } \\
\text { acontecimentos até o ano de } \\
1815 .\end{array}$ & 33. $2^{\mathrm{a}}$ batalha dos Guararapes. & \\
\hline
\end{tabular}




\begin{tabular}{|c|c|}
\hline $\begin{array}{l}\text { 34. Campanhas do sul desde } \\
1811 \text { até a incorporação da } \\
\text { Província Cisplatina ao } \\
\text { reino unido de Portugal, } \\
\text { Brasil e Algarves. }\end{array}$ & 34. Conspiração de Beckman. \\
\hline $\begin{array}{l}\text { 35. Acontecimentos de } 1820 \text { em } \\
\text { Portugal - e no Brasil desde } \\
\text { essa época até o regresso da } \\
\text { Corte. }\end{array}$ & 35. Revolta dos mascates. \\
\hline 36. Tentativa de 1817 & 36. Mamelucos. \\
\hline $\begin{array}{l}\text { 37. Regência do Sr. D. Pedro - } \\
\text { Aclamação de } \\
\text { Independência. }\end{array}$ & 37. Duclerc, e Duguay Troin. \\
\hline $\begin{array}{l}\text { 38. Movimento de Pernambuco } \\
\text { em } 1824 \text {. }\end{array}$ & $\begin{array}{l}\text { 38. Projeto de Revolução em } \\
\text { Minas - Tiradentes. }\end{array}$ \\
\hline 39. Lord Cockrane. & $\begin{array}{l}\text { 39. Descoberta das Minas no } \\
\text { Brasil. }\end{array}$ \\
\hline $\begin{array}{l}\text { 40. Fundação das principais } \\
\text { cidades do Brasil. }\end{array}$ & $\begin{array}{l}\text { 40. Influência do Marquês de } \\
\text { Pombal no Brasil. }\end{array}$ \\
\hline
\end{tabular}




\section{ANEXO IV - QUADRO COMPARATIVO DA DISTRIBUIÇÃO DAS NOTAS ENTRE A PRIMEIRA EDIÇÃO (EM DOIS VOLUMES) E A SEGUNDA EDIÇÃO (EM UM VOLUME) DE COMPÊNDIO DA HISTÓRIA DO BRASIL}

\begin{tabular}{|c|c|c|}
\hline $\begin{array}{l}\text { NOTAS DE COMPÊNDIO DA } \\
\text { HISTÓRIA DO BRASIL }\end{array}$ & $\begin{array}{l}\text { PRIMEIRA EDIÇÃO } \\
\text { (2 volumes) }\end{array}$ & $\begin{array}{l}\text { DEMAIS EDIÇÕES } \\
\text { (1 volume) }\end{array}$ \\
\hline Introdução & 2 & \\
\hline \multicolumn{3}{|l|}{ Capítulo Primeiro } \\
\hline I & 2 & 1 \\
\hline II & 3 & \\
\hline III & 1 & \\
\hline IV & 3 & \\
\hline $\mathrm{V}$ & 2 & \\
\hline \multicolumn{3}{|l|}{ Capítulo Segundo } \\
\hline $\mathrm{I}$ & 4 & 2 \\
\hline \multicolumn{3}{|l|}{ II } \\
\hline III & 2 & 1 \\
\hline IV & 2 & 1 \\
\hline $\mathrm{V}$ & 4 & \\
\hline \multicolumn{3}{|l|}{ Capítulo Terceiro } \\
\hline I & 2 & 2 \\
\hline II & 1 & \\
\hline III & 1 & \\
\hline IV & 2 & 1 \\
\hline $\mathrm{V}$ & 3 & 1 \\
\hline VI & 4 & 1 \\
\hline VII & 4 & 3 \\
\hline VIII & 2 & \\
\hline \multicolumn{3}{|l|}{ Capítulo Quarto } \\
\hline $\mathrm{I}$ & 3 & 1 \\
\hline II & 2 & \\
\hline III & 2 & \\
\hline IV & 2 & \\
\hline $\mathrm{V}$ & 1 & \\
\hline VI & 4 & 1 \\
\hline \multicolumn{3}{|l|}{ Capítulo Quinto } \\
\hline I & 4 & \\
\hline II & 4 & \\
\hline III & 1 & \\
\hline IV & 4 & \\
\hline $\mathrm{V}$ & 3 & \\
\hline VI & 6 & 1 \\
\hline \multicolumn{3}{|l|}{ Capítulo Sexto } \\
\hline $\mathrm{I}$ & 1 & \\
\hline II & 4 & \\
\hline III & 4 & \\
\hline IV & 5 & \\
\hline $\mathrm{V}$ & 2 & \\
\hline VI & 3 & \\
\hline Total & 99 & 17 - falta 1 \\
\hline
\end{tabular}




\section{ANEXO V - DOCUMENTOS EM APENSO À PRIMEIRA EDIÇÃO}

A Assento, e condições, com que os senhores do Conselho Supremo residentes no Arrecife, entregam ao senhor mestre de campo general Francisco Barreto, Governador em Pernambuco, a cidade Mauricéa, Arrecife, e mais forças, e fortes juntos delas, e mais praças, que tinham ocupadas na banda norte, a saber: ilha de Fernão de Noronha, Ceará, Rio Grande, Paraíba, ilha de Itamaracá: acordado tudo Pelos comissários de uma, e outra parte, abaixo assinados.

B - Decreto de 7 de março de 1821 pelo qual S. M. F.declara a intenção de voltar a Lisboa, deixando encarregado do Governo Provisório do Reino do Brasil o Príncipe Real do Reino Unido.

C Decreto de 22 de abril de 1821 estabelecendo a Regência do Brasil na pessoa do Príncipe Real do Reino Unido.

- Instruções a que se refere o Real Decreto de 22 de abril de 1821.

D C Carta do Príncipe D. Pedro dirigida ao seu augusto pai, com data de 21 de setembro de 1821.

E $\quad$ - Representação dirigida ao Príncipe Regente do Brasil pela Junta Provincial de S. Paulo em 24 de dezembro de 1821.

- Representação da Câmara de S. Paulo de 31 de dezembro de 1821.

- Representação do Bispo de S. Paulo de $1^{\circ}$ de janeiro de 1822.

- Ofício ao Governador de S. Paulo de 3 de janeiro de 1822.

- Ofício do orador da Deputação de S. Paulo em 26 de janeiro de 1822.

F - Termo da vereação do dia 9 de janeiro de 1822.

- Representação do povo do Rio de Janeiro, dirigida ao senado da Câmara, a que se refere o anterior discurso. 
G - Vereação extraordinária do Senado da Câmara desta Corte em 23 de maio de 1822.

- Fala que a sua alteza real o Príncipe Regente Constitucional e Defensor Perpétuo do Brasil dirigiu ao Senado da Câmara desta cidade pela voz do seu presidente no ato de apresentar ao mesmo senhor a representação do povo desta cidade, sobre a convocação de uma assembléia geral nesta corte.

- A convocação de uma assembléia geral nesta corte.

- Representação que a S. A. R. o Príncipe Regente Constitucional e Defensor Perpétuo do Reino do Brasil dirige o povo do rio de Janeiro pela Câmara desta Corte.

H Instalação do conselho de Estado sob a Presidência do Príncipe Regente do Brasil.

- Representação que a S. A. R. o Príncipe Regente elevaram os Procuradores e o Ministério, corroborando a súplica do povo dirigida pelo Senado da Câmara no dia 23 de maio.

- Decreto de 3 de juno de 1822 mandando convocar uma Assembléia Constituinte e Legislativa, composta dos deputados das províncias do Brasil, em consequiência da anterior representação.

- Decreto da mesma data pela qual manda o Príncipe Regente rechaçar das costas do Brasil qualquer expedição portuguesa, que chegue a elas com o intuito de desembarcar sem o seu consentimento.

J Manifesto do Príncipe Regente do Reino do Brasil aos Governos e Nações Amigas.

K - Edital do Senado da Câmara do Rio de Janeiro fixando o dia 12 de outubro de 1822 para a aclamação do Príncipe Regente como Imperador Constitucional do Brasil.

I - Fala do Trono com que o Sr. D. Pedro I, Imperador Constitucional e Defensor Perpétuo do Brasil, abriu a Assembléia Constituinte no dia 3 de maio de 1823.

N Proclamação publicada no dia 13 de novembro de 1823 em conseqüência da dissolução da Assembléia Constituinte. 
O - Manifesto que sua S. M. O Imperador mandou aos brasileiros no dia 16 de novembro de 1823 com o objeto de aplacar a impressão causada pela dissolução da Assembléia Constituinte.

P Proclamação de Manoel de Carvalho Paes de Andrade, presidente intruso de Pernambuco, publicada no dia 2 de julho de 1824.

- Manifesto de Manoel de Carvalho Paes de Andrade, proclamando a Confederação do Equador, publicada em Pernambuco, publicada no dia 24 de novembro de 1824.

- Portaria do Ministro e Secretário de Estado dos Negócios do Império, a que se refere o anterior Manifesto.

Q - Nota importantíssima do Ministro e Secretário de Estado das Relações Exteriores da República das Províncias Unidas do Rio da Prata, D. Ma noel José Garcia ao Ministro e Secretário dos Estado de Negócios Estrangeiros do Império do Brasil.

R Manifesto ou Exposição fundada e justificada do Procedimento da Corte do Brasil a respeito do governo das Províncias Unidas do Rio da Prata: e dos motivos que a obrigaram a declarar a guerra ao referido Governo.

S - Fala do Trono com que o Senhor D. Pedro I, Imperador Constitucional e Defensor Perpétuo do Brasil, abriu a primeira seção da primeira Assembléia Legislativa deste Império no dia 6 de maio de 1826.

T - Convenção preliminar de 24 de maio de 1827, celebrada entre o Enviado Extraordinário e Ministro Plenipotenciário da República de Buenos Aires D. Manuel José Garcia, e os comissários brasileiros, na cidade do Rio de Janeiro; a qual não foi ratificada pelo governo daquela República por uma Resolução de 25 de junho seguinte.

- Resolução do Governo Argentino.

- Mensagem do excelentíssimo Senhor Presidente da República ao Congresso Geral Constituinte. 
U - Fala com que S. M. I. o Senhor D. Pedro I abriu a primeira seção da Segunda Legislatura do Império, no dia 3 de maio de 1830.

V Proclamação que o Senhor D. Pedro I aos ministros, e em geral a todos os povos do Brasil, publicada na cidade de Ouro Preto, no dia 23 de fevereiro de 1831.

W - Representação dirigida ao Senhor D. Pedro I, Imperador do Brasil, por vinte e três deputados e um senador, exigindo uma reparação da afronta, no dia 13 e 14 de março de 1831.

Y Manifesto do coronel Bento Gonçalves da Silva, cabaça da rebelião do Rio Grande do Sul, publicado no dia 25 de setembro de 1835.

Z Peças oficiais relativas à renúncia que fez o senador Diogo Antonio Feijó do cargo de Regente no dia 19 de setembro de 1837.

- Manifesto a que se refere o anterior ofício.

Aa - Proclamação da Assembléia Geral, pela qual se faz constar ao povo do Brasil, que o Senhor D. Pedro II foi declarado Maior, e entre no exercício que pela Constituição lhe compete.

Bb - Notícia do ato de coroação e Sagração do Sr, D. Pedro II no dia 18 de julho de 18 


\section{BIBLIOGRAFIA}

\section{OBRAS DE JOSÉ INÁCIO DE ABREU E LIMA}

\section{Publicadas}

ABREU E LIMA, José Inácio de. Memória sobre a planta conhecida na República da Colômbia pelo nome genérico guaco própria das regiões equinociais e sobre as suas principais virtudes. Rio de Janeiro: Revista Médica Fluminense, t. 3, 1826-1837.

Bosquejo histórico, político e literário do Império do Brasil. Niterói: Tipografia Niterói do Rego e Companhia, 1835.

. Memória sobre a elefância. Revista Médica Fluminense, Rio de Janeiro, 1837.

. Compêndio da História do Brasil. Rio de Janeiro: Laemmert, 1843a. 2 t.

. Compêndio da História do Brasil. Rio de Janeiro: Laemmert, 1843b. 1 t.

. Resposta ao cônego Januário da Cunha Barbosa. Análise do Primeiro Juízo. Recife: Tipografia M. Faria, 1844.

. Sinopse ou dedução cronológica dos fatos mais notáveis da história do Brasil. Recife: Tipografia M. F. de Farias, 1845.

. A cartilha do povo. Recife: Tipografia Viúva Roma e Filhos, 1849.

História Universal. Rio de Janeiro: Laemmert, 1846-1847.

. O socialismo. Recife: Tipografia Universal, 1855.

Discurso recitado. Discursos Recitados no ano da instalação solene do hospital português provisório de Pernambuco. Recife, 1855. 
. Reforma eleitoral. Eleição direta. In: BANDEIRA, Dr. Antônio Herculano de Souza. Recife: Coleção de artigos, 1862.

O Deus dos judeus e o Deus dos cristãos. Terceira resposta ao Sr. Cônego Joaquim Pinto de Campos. Recife, 1867.

. Resumen histórico de la última dictadura del libertador Simón Bolívar. Rio de Janeiro: O Norte, MCMXXII.

Inéditas

ABREU E LIMA, José Inácio. Memória sobre os limites entre o Brasil e a República da Colômbia. 1826.

. A mulher católica.

Direito Criminal.

. Ordenança geral do Império do Brasil, seguida de um índice da legislação respectiva.

. Notas ao Código Criminal do Império do Brasil, seguidas de um índice da legislação respectiva.

Ensaio crítico sobre diversas obras de autores modernos.

. Observações relativas à História do Brasil, principalmente a respeito de pontos controvertidos da mesma história. Recife.

\section{Imprensa periódica}

Torre de Babel. Rio de Janeiro, 1833.

Arca de Noé. Rio de Janeiro, 1833.

Raio de Júpiter. Niterói , 1836.

O Maiorista. Rio de Janeiro, 1840. 


\section{FONTES}

\section{Biblioteca Nacional}

\section{Obras Raras}

Imprensa Periódica

Aurora Fluminense. Jornal político e literário. Rio de Janeiro, 1833.

Arca de Noé. Rio de Janeiro, 1833.

O Maiorista. Rio de Janeiro, 1840.

Nova Luz Brasileira. Rio de Janeiro, 1831.

Raio de Júpiter. Niterói, 1836.

Torre de Babel. Rio de Janeiro, 1833.

\section{$\underline{\text { Documentos }}$}

ABREU E LIMA, José Inácio de. Primeira carta do General Abreu e Lima ao redator da Aurora, em resposta ao artigo, Rio de Janeiro, do seu número 735, de sexta-feira, 15 de fevereiro. Rio de Janeiro: Tipografia de Gueffier e Comp., 1833. 4p. 39,023 n. 1.

Segunda carta do General Abreu e Lima ao redator da Aurora em resposta ao artigo, Rio de Janeiro, do seu número 735, de sexta-feira, 15 de fevereiro. Rio de Janeiro: Tipografia de Gueffier e Comp. 1833. 4p. 39,023 n.1.

\section{IHGB}

\section{Revista do Instituto Histórico e Geográfico Brasileiro}

do Tomo I (1839) ao Tomo XXI (1858). 


\section{Documentos Manuscritos}

ABREU E LIMA, José Inácio de. Memorial reservado para ser apresentado a S. M. O Imperador pelo General Abreu e Lima. 2 de agosto de 1841. Lata 11: Pasta 5.

Carta solicitando a retirada de seu nome do quadro de sócios do IHGB, 23 de abril de 1844. Lata 611: Pasta 26.

Cartas ao General Francisco de Paula Santander, extraídas do arquivo Santander e publicadas pela Academia de História Colombiana, v. IX e X; Carta de 18 de setembro de 1868 (publicada na Revista América Ilustrada, Nova York, 1873; na Revista da Colômbia, Bogotá ,1875; na Revista de Buenos Aires, Buenos Aires, 1868); Carta de 16 de novembro de 1822, Caracas; Carta de 14 de junho de 1823, Maracay. Lata 477: Pasta 36.

- Memorial reservado para ser apresentado a S. M. O Imperador pelo General Abreu e Lima. IHGB, 2 de agosto de 1841. Lata 11: Pasta 5.

.Carta solicitando a retirada de seu nome do quadro de sócios do IHGB, 23 de abril de 1844, Lata 611: Pasta 26.

OLIVEIRA, Machado. Memorial dirigido ao IHGB sobre as calúnias levantadas ao seu governo durante os anos de 1832 e 1833, na Província do Pará pelos modernos historiadores, especialmente o General Abreu e Lima. 26 de outubro de 1843. Lata 139: Pasta 92.

\section{Núcleo de Documentação e Memória (NUDOM) - Colégio Pedro II}

Anuário do Colégio D. Pedro II (1949-1950). Rio de Janeiro: República dos Estados Unidos do Brasil - MEC, v. XV, 1954.

Perguntas de História do Brasil. Exame de 1848.

Programas de História do Brasil. 1850, $7^{\circ}$ ano.

Programas de História do Brasil . 1851, $7^{\circ}$ ano.

Programas de História do Brasil. 1858, $4^{\circ}$ ano. 


\section{DICIONÁRIOS, ANAIS E ANUÁRIOS}

Anais da Assembléia Constituinte do Império do Brasil. Brasília: Senado Federal, 1972.

BARATA, Carlos Almeida; BUENO, Antônio Henrique Cunha. Dicionário das Famílias Brasileiras. São Paulo: Ibero-América, 2000. 2 v.

BARÃO DO RIO BRANCO. Efemérides brasileiras. Rio de Janeiro, 1946.

BLAKE, Augusto Vitorino Alves do Sacramento. Dicionário bibliográfico brasileiro. 2. ed. Rio de Janeiro: Imprensa Nacional, 1898. 7 v.

BOBBIO, Norberto et al. Dicionário de política. Brasília: EdUnB, 1983.

CAMPANHOLE, Adriano, CAMPANHOLE Hilton Lobo. Todas as Constituições do Brasil. $3^{\text {a }}$ ed, São Paulo: Editora Atlassa, 1978.

COSTA, Pereira da. Dicionário de pernambucanos ilustres. Pernambuco, s/d.

CUNHA, Antônio Geraldo. Dicionário etimológico Nova Fronteira da língua portuguesa. 2 ed, 9. imp. Rio de Janeiro: Nova Fronteira.

HOUAISS, Antônio; VILLAR, Mauro de Salles. Dicionário Houaiss da língua portuguesa. Rio de Janeiro: Objetiva, 2001.

Le Nouveau Petit Robert. Paris: Dictionaires Le Robert, 1993.

MORAES e SILVA, Antonio de. Dicionário da língua portuguesa recopilado dos vocabulários impressos até agora, segunda edição novamente emendado e muito acrescentado. 2 ed. Lisboa, 1813.

PROFESSORES catedráticos e efetivos. In: Anuário do Colégio Pedro II, v. XV, 1949 1950. RJ: República dos Estados Unidos do Brasil - MEC , 1954. p. 405-406.

SAINT-ADHOLPHE, J.C.R. Milliet de. Dicionário geográfico e descritivo do Império do Brasil. Tradução Dr. Caetano Lopes de Moura. 2. ed. Paris, 1863. 
SILVA, Inocêncio Francisco da; BRITO, Aranha. Dicionário biobibliográfico português. Lisboa: Imprensa Nacional, 1893.

SISSON, Sebastião A. Galeria dos brasileiros ilustres (os contemporâneos). $2^{\mathrm{a}}$ ed. São Paulo: $2 \mathrm{v}$.

SOBRINHO, I. F. Velho. Dicionário Bio-bibliográfico Brasileiro. v.1 Rio de Janeiro: Irmãos Pongetti, 1937.

\section{ARTIGOS E LIVROS}

ABREU, Capistrano de. Capítulos de História colonial. 4. ed. Rio de Janeiro: Briguiet, 1954.

Fases do Segundo Império. In: Ensaios e estudos (crítica e história) $3^{\mathrm{a}}$ série, 2 ed. Rio de Janeiro: Briguiet, 1969.

Necrológio de Francisco Adolfo de Varnhagen, Visconde de Porto Seguro. In: Ensaios e Estudo, $1^{a}$ série. Rio de Janeiro: Civilização Brasileira/MEC, 1975. (O artigo foi publicado originalmente no Jornal do Comércio de 16 a 20 de dezembro de 1878.)

ALENCAR, José de. Ficção completa. Rio de Janeiro: Aguilar, 1965.

Benção paterna. In: Sonhos d'ouro. Ficção completa e outros escritos. Rio de Janeiro: Aguilar, 1965.

ALMEIDA, José Ricardo Pires de. História da instrução pública no Brasil (1500 - 1889): história e legislação. São Paulo: INEP, PUC-SP, 1989.

ANDERSON, Benedict. Nação e consciência nacional. São Paulo: Ática, 1989.

ANDRADA E SILVA, José Bonifácio de. Representação à Assembléia Constituinte e Legislativa do Império do Brasil sobre a escravatura. In: SOUSA, Otávio Tarquínio de. (Org.) O pensamento vivo de José Bonifácio. S. Paulo: Martins, 1945. 
ARENDT, Hannah. O conceito de história - antigo e moderno. In: Entre o passado e o futuro. 2 ed. São Paulo: Perspectiva, 1972.

ARIÉS, Philippe; CHARTIER, Roger. História da vida privada: da renascença ao século das Luzes. V. 3. São Paulo: Cia das Letras, 1991.

ARMITAGE, João. História do Brasil. Rio de Janeiro: Tecnoprint Gráfica, 1965.

BARRETO, Luís Filipe. Descobrimentos e renascimentos. Formas de ser e pensar nos século XV e XVI. Lisboa: Imprensa Nacional/Casa da Moeda, 1982.

BARROSO, José Liberato. A instrução pública no Brasil. Rio de Janeiro: Garnier, 1867.

BASILE, Marcelo Otávio Neri de Campo. O império em construção: projetos de Brasil e ação política na Corte regencial. Tese de doutoramento em História. Instituto de Filosofia e Ciências Sociais da Universidade Federal do Rio de Janeiro, 2004. Mimeografado.

BAUMAN, Zygmunt. Identidade. Rio de Janeiro: Jorge Zahar Editor, 2005.

BEAUCHAMP, Alphonse. História do Brasil. Lisboa: Oficina de JFM de Campos, 1817.

BENJAMIN, Walter. Sobre o conceito de História, In: Magia e técnica. Arte e política. v. 1. São Paulo: Brasiliense, 1985.

BERNARDES, Antônio de Mendonça. Pernambuco e o Império (1822-1824): sem constituição soberana não há união. In: JANCSÓ, István (Org.) Brasil: Formação do Estado e da Nação. São Paulo: Hucitec, 2003.

BERNARDES, José. Abreu e Lima, herói sul americano. Rio de Janeiro: Nosso Brasil, 1978.

BITTENCOURT, Circe Maria Fernandes. Pátria, civilização e trabalho: o ensino de História nas escolas públicas (1917-1939). São Paulo: Loyola, 1990.

Livro didático e conhecimento histórico: uma história do saber escolar. Tese de doutoramento em História: Faculdade de São Paulo, 1993. 
Editores e autores de compêndios e livros de leitura. Educação e Pesquisa. São Paulo, v. 30, n.3, p. 475-491, set.-dez. 2004.

BLACKBURN, Robin. A queda do escravismo colonial: 1776-1848. Rio de Janeiro: Record, 2002.

BLANCO-FOMBONA, Rufino. El pensamiento vivo de Bolívar. Buenos Aires: Editorial Losada, s/d.

BLOCH, Marc. Introdução à história. Lisboa: Publicações Europa-América, 1965.

BOBBIO, Norberto. Estado. In: Estado-Guerra Enciclopédia Einaudi. Lisboa: Imprensa Nacional/ Casa da Moeda, 1989.

BORGES, Vany Pacheco. Grandezas e misérias da biografia. In: PINSKY, Carla Bassanezi (Org.). Fontes históricas. São Paulo: Contexto, 2005.

BOURDIEU, Pierre. A ilusão biográfica. In: FERREIRA, Marieta de Moraes; AMADO, Janaína (Org.). Usos e abusos da história oral. Rio de Janeiro: Fundação Getúlio Vargas, 1996.

BUENO, Alexei; ERMAKOFF, George. (Org.) Duelos no serpentário. Uma antologia da polêmica intelectual no Brasil. 1850-1950. Rio de Janeiro: G. Ermakoff, 2005.

BUENO, José Antônio Pimenta. Direito público brasileiro e análise da constituição do Império. Brasília: Senado federal, 1978.

BURKE, Peter. A construção do rei. Rio de Janeiro: Zahar, 1994.

CANCLINI, Nestor Garcia. Consumidores e cidadãos. Rio de Janeiro: Editora UFRJ, 2001.

CÂNDIDO, Antônio. Formação da literatura brasileira (momentos decisivos). 4 ed. São Paulo: Martins, 1971.

O escritor e o público. Literatura e Sociedade. São Paulo: C. E. Nacional, 1985.

CARBONELL, Charles-Olivier. Historiografia. Lisboa: Teorema, 1987. 
CARBONELL, Diego. Biografia e notas. In: Resumo histórico da última ditadura do Libertador Simón Bolívar. Rio de Janeiro: Editora O Norte, 1922.

CARR, E.H. O que é História? Rio de Janeiro: Paz e Terra, 1976.

CARBONELL, Diego. Biografia e notas. In: Resumen Histórico de la última dictadura del libertador Simón Bolívar. Comprobada por documentos. Rio de Janeiro: Empr. "O Norte", MCMXXVII.

CARVALHO, José Murilo. Pontos e bordados. Escritos políticos de história e política. Belo Horizonte: Editora da UFMG, 1988.

CASAL, Aires do. Corografia brasílica. Belo Horizonte: Itatiaia, São Paulo: EDUSP, 1976.

CASTRO, Moacir Werneck de. O libertador. A vida de Simón Bolívar. 2. ed. Rio de Janeiro: Rocco, 1989.

CERTEAU, Michel de. A operação histórica. In: LE GOFF, Jacques. J.; NORA, Pierre (Org.) História: novos problemas. Rio de Janeiro: Francisco Alves, 1976.

A escrita da história. Rio de Janeiro: Forense universitária, 1982.

CHACON, Vamireh. História das idéias socialistas no Brasil. Rio de Janeiro: Civilização Brasileira, 1965.

Abreu e Lima General de Bolívar. Rio de Janeiro: Paz e Terra, 1983.

CHARTIER, Michel. Império. In: Enciclopédia Einaudi: Estado-Guerra. Lisboa: Imprensa Nacional Casa da Moeda, 1989.

CHARTIER, Roger.. Por uma sociologia histórica das práticas culturais. In; A história cultural: entre práticas e representações. Lisboa: Difel, 1990. (Org.) Práticas da leitura. São Paulo: Estação Liberdade, 1996.

CHERVEL, André. História das disciplinas escolares. Teoria e Educação. Porto Alegre, Pannonica, jan.- jun.1990. 
. Quando surgiu o secundário? Revista da Faculdade de Educação de São

Paulo, 1992.

CHIZZOTTI, Antonio. As origens da instrução pública no Brasil: análise interpretativa da legislação pública nas origens de sua constituição, seus pressupostos e as indicações para a filosofia da educação. São Paulo: PUC-SP. 1975. Dissertação de mestrado. Mimeografado.

CHOPIN, Alain. História dos livros e das edições didáticas escolares: sobre o estado da arte. Educação e Pesquisa, São Paulo, v. 30, set.-dez. 2004.

CHRISTOFOLETTI, A. Perspectivas da geografia. São Paulo: Difel, 1985.

COUTINHO, Afrânio (dir.) A literatura no Brasil. Rio de Janeiro: Ed. Sul Americana, 1955, $2 \mathrm{v}$.

CUNHA, Manuela Carneiro da. Imagens de índios do Brasil:o século XVI. In: PIZARRO, Ana. (Org.) América latina. Palavras, literatura e cultura. vol. 1. A situação colonial. S. Paulo: Memorial; Campinas: Unicamp, 1993.

DARNTON, Robert. História da leitura. In: BURKE, Peter (Org.) A escrita da história. Novas perspectivas. São Paulo: UNESP,1992.

DIAS, Maria Odila da Silva. A interiorização da metrópole (1808-1853), In: MOTA, Carlos Guilherme (Org.). 1822: Dimensões. São Paulo: Perspectiva, 1972.

DEBRET, J. B. Viagem pitoresca e histórica ao Brasil. São Paulo: Martins, 1965.

DORIA, Escragnolle. Memória histórica: comemorativa do $1^{\circ}$ centenário do Colégio Pedro Segundo, (1837-1937). Brasil: Ministério da Educação Rio de Janeiro, 1937.

ECO, Umberto. Geografia imperfeita de Corto Maltese. In: Entre a memória e a ironia. Rio de janeiro: Record, 2006.

ELIAS, Norbert. O processo civilizador. Rio de Janeiro: Jorge Zahar, 1990. 
FALCON, Francisco J. Calazans. Ilustração e revolução em Portugal e na América portuguesa. In: Estudos em Homenagem a Luís António de Oliveira Ramos. Porto: Faculdade de Letras da Universidade do Porto, 2004, p. 521-526.

FERRO, Marc. Comment on raconte l'listoire aux enfants à travers le monde. Paris: Payot, 1981.

A história vigiada. São Paulo: Martins Fontes, 1989.

FEBVRE, Lucien. Honra e pátria. Rio de Janeiro: Civilização Brasileira, 1998.

FIGUEIREDO, Luciano. Os sentidos da colonização na América portuguesa. In: MAGALDI, Ana Maria; ALVES, Claudia; GONDRA, José G. (Org.). Educação no Brasil: história, cultura e política. Bragança Paulista: Edusf, 2003.

FONSECA, SILVIA Carla Pereira de Brito. A idéia de república no Império do Brasil: Rio de Janeiro e Pernambuco (1824-1834). Rio de Janeiro: UFRJ-IFCS, 2004, (tese de doutoramento). Mimeografada.

FREIRE, Gilberto. Casa Grande e Senzala. Formação da família brasileira sob o regime de economia patriarcal. 11. ed. brasileira. Rio de Janeiro, 1964.

Sobrados e Mucambos. 4. ed. t. I, Rio de Janeiro: Livraria José Olympio Editora, 1968.

Heróis e vilões no romance brasileiro. São Paulo: Cultrix/Edusp, 1979.

FREMONT, A. A região, espaço vivido. Coimbra, 1980.

FURET, François. O nascimento da história. In: A oficina da história. Lisboa: Gradiva, s/d.

GAGNEBIN, Jeanne Marie. Lembrar, escrever, esquecer. São Paulo: Ed. 24, 2006.

GANDAVO, Pero de Magalhães. História da Província Santa Cruz. Tratado da Tera do Brasil. São Paulo: Obelisco, 1964.

GASPARELLO, Arlete Medeiros. Construtores de identidades: a pedagogia da nação nos livros didáticos da escola brasileira. São Paulo: Iglu, 2004. 
GIL, José. Nação. In: Estado-Guerra Enciclopédia Einaudi. Lisboa: Imprensa nacional/ Casa da Moeda, 1989.

GUIMARÃES, Argeu. Um brasileiro na epopéia bolivariana. Recife: Editora Moraes, 1926.

GUINZBURG, Carlo. Provas e possibilidades: à margem de 'Il ritorno de Marin Guerre, de Nalalie Zemon Davies. In: A micro-história e outros ensaios. Lisboa: Difel, 1991.

GOMES, Flávio; MOREL, Marco. Trajetórias atlânticas: dois brasileiros no Haiti no início dos oitocentos, In: PESAVENTO, Sandra (Org.). História cultural. Experiências de pesquisa. Porto Alegre: Editora da UFRGS, 2003.

GUERRA, Francisco-Xavier. A nação moderna: nova legitimidade e velhas identidades. In: ISTVÁN, Jancsón. Brasil: formação do Estado e da nação. São Paulo: Hucitec, Unijuí, Fapesp, 2003.

GUIMARÃES, Manuel L. Salgado. Reinventando a tradição: sobre Antiquariado e Escrita da História. Humanas: Revista do Instituo de Filosofia e Ciências Humanas/UFRGS. Porto Alegre, v. 16, jan.-jun.1993.

Nação e civilização nos trópicos: o IHGB e o projeto de uma história nacional. Estudos Históricos. Rio de Janeiro: n. 1, 1998.

Para reescrever o passado como história: o IHGB e a Sociedade dos Antiquários do Norte. In: HEIZER, Alda; VIEIRA, Antonio Augusto Passos (orgs.) Ciência e civilização nos trópicos. Rio de Janeiro: Access, 2001.

O presente do passado: as artes de Clio em tempos de memória. ABREU, Marta, SOIHET, Rachel, GONTIJO, Rebeca. (Org.). In: Cultura política, historiografia e ensino de história. Rio de Janeiro: Civilização Brasileira - FAPERJ, 2007.

HAIDAR, Maria de L. M. O ensino secundário no Império do Brasil. São Paulo: EDUSP, 1972. 
HALL, Stuart. Da diáspora. Identidades e mediações culturais. Belo Horizonte: Editora UFMG; Brasília: Representação da Unesco no Brasil, 2003.

HALLEWELL, Laurence. O livro no Brasil (sua história). São Paulo: T. A Queiroz/EDUSP, 1985.

HIRSCHIMAN, Albert. Suavidade, poder e fraqueza da sociedade de mercado. In: A economia como ciência moral e política. São. Paulo: Brasiliense, 1986.

A retórica da intransigência: perversidade, futilidade, ameaça. São Paulo: Cia das Letras, 1992.

HOBSBAWM, Eric. Nações e nacionalismo desde 1870. Rio de Janeiro: Paz e Terra, 1991. . Sobre a história. São Paulo: Companhia das Letras, 1998. A era das revoluções: Europa, 1789-1848. Rio de Janeiro: Paz e Terra, 1977.

HOLANDA, Sérgio Buarque de . "Apresentação" a J. J. da Cunha Azeredo Coutinho. Obras econômicas: 1974-1804. São Paulo: Cia. Editora Nacional, 1966.

ISTVÁN, Jancsó; PIMENTA, João Paulo G. Peças de um mosaico. (ou Apontamentos para o estudo da emergência da identidade nacional brasileira). In: Mota, Carlos Guilherme. (Org.). Viagem incompleta. A experiência brasileira. (1500-2000). Formação: histórias. São Paulo: Senac, 2000.

JENSEN, Jaime Antonio Etcheparae. Las concepciones políticas de los libertadores americanos Simón Bolívar, Bernardo O’Higgins y José de San Martín, fundamentos y proyecciones http://www.civila.com/chile/archivos.

JOBIM, José Luís (Org.). Introdução ao Romantismo. Rio de Janeiro: EdUERJ, 1999.

KARASCH, Mary. Minha nação: identidades escravas no fim do Brasil colonial. In: SILVA, Maria Beatriz Nizza da (Org.). Brasil, colonização e escravidão. Rio de Janeiro: Nova Fronteira, 2000. 
A vida dos escravos no Rio de Janeiro. 1808 - 1859. São Paulo: Cia das Letras, 2000.

KOSELLECK, Reinhart. Futuro pasado. Para una semántica de los tiempos históricos. Barcelona: Paidós, 1993

Uma história dos conceitos: problemas teóricos e práticos. Estudos Históricos. Rio de Janeiro, v. 5, n. 10, 1992.

Los estratos del tiempo: estúdios sobre la historia. Barcelona: Paidós, 2001

LE GOFF, Jacques. Calendário; Monumento e documento. In Memória-História Enciclopédia Einaudi. Lisboa: Imprensa nacional/ Casa da Moeda, 1984.

LEHEMBRE, Bernard. Naissance de l'école moderne. Les textes fondamentaux, 17911804. Paris: Editions Nathan, 1989.

LEVI, Giovanni. Usos da biografia. In: FERREIRA, Marieta de Moraes; AMADO, Janaína (Org.). Usos e abusos da História Oral. Rio de Janeiro: Fundação Getúlio Vargas, 1996.

LÉVY, Calmann. Discours et conférences. Paris, 1887. p. 286.

MACEDO, Joaquim Manuel de. Lições de História do Brasil para uso dos alunos do Imperial Colégio de Pedro II $-4^{\circ}$ ano. Rio de Janeiro: Garnier,1861a.

. Lições de História do Brasil para uso dos alunos do Imperial Colégio de PedroII $-7^{\circ}$ ano. Rio de Janeiro: Garnier, 1861b.

. Lições de História do Brasil para uso das escolas de instrução primária . Rio de Janeiro: Garnier 1865c.

Ano Biográfico Brasileiro. $1^{\circ}$ vol. Rio de Janeiro: Tipografia e Litografia do Imperial Instituto Artístico, 1876.

MAGNOLI, Demétrio. O corpo da pátria. Imaginação geográfica e política externa no Brasil (1808-1912). São Paulo: Editora da UNESP/Moderna, 1997. 
MAGALHÃES JUNIOR, Raimundo (Org) Três panfletários do Segundo Império. São Paulo: Cia Editora Nacional, 1956.

MALTESE, Corto. Geografia imperfeita. Rio de Janeiro: Record, 2006.

MATTOS, Hebe. Governador dos negros, crioulos e mulatos. Revista de História da Biblioteca Nacional. Rio de Janeiro, ano 1, n. 7, jan. 2006.

MATTOS, Ilmar Rohloff de. Um 'país novo': A formação da identidade brasileira e a identidade da Argentina. In: A visão do outro: seminário Brasil - Argentina. Brasília: Funag, 2000a.

O tempo saquarema. A formação do Estado imperial. 5 ed. São Paulo: Hucitec, 2003.

Construtores e herdeiros. A trama de interesses na construção da unidade política. In ISTVÁN, Jancsó (Org.). Independência: história e historiografia. São Paulo: Hucitec: Fapesp, 2005.

Do Império do Brasil ao Império do Brasil. In: Estudos em homenagem a Luís António de Oliveira Ramos. Porto: Faculdade de Letras da Universidade do Porto, 2004.

MATTOS, Selma Rinaldi de. O Brasil em Lições. A história como disciplina escolar em Joaquim Manuel de Macedo. Rio de Janeiro: Access, 2000b.

MARTINS, Eduardo Vieira. A fonte subterrânea: José de Alencar e a retórica oitocentista. Londrina : EdUEL, 2005.

MARTIUS, Karl Ph. Von. Como deve se escrever a história do Brasil. Rio de Janeiro: IHGB, 1991.

MAZIN, Diogo; STEDILE, Enrique Miguel. Abreu e Lima general das massas. São Paulo: Expressão Popular, 2006.

MELLO, Evaldo Cabral de. Rubro veio. O imaginário da restauração pernambucana. Rio de Janeiro: Nova Fronteira, 1986. 
A ferida de narciso. Ensaio de história regional. São Paulo: Senac, 2001.

. A outra independência: o federalismo pernambucano. São Paulo: ED. 34, 2004.

MEYER, Marlyse. Folhetim. Uma história. São Paulo: Cia. das Letras, 1996.

MIGNOLO, Walter D. Histórias locais / projetos globais. Colonialidade, saberes subalternos e pensamento liminar. Belo Horizonte: Editora da UFMG, 2003.

MOACIR, Primitivo. A instrução e o Império. São Paulo: Nacional, 1936-1938, 3 v..

MOREL, Marco; BARROS, Mariana Monteiro de. Palavra, imagem e poder. O surgimento da imprensa no Brasil do século XIX. Rio de Janeiro: DP\&A, 2003.

Papéis incendiários, gritos e gestos: a cena pública e a construção nacional nos anos de 1820-1830. In: Topoi: Revista de História, no 1, Rio de janeiro: 7 Letras, 2000.

MYERS, Jorge. Identidades porteñas. El discurso ilustrado en torno a la nación y el rol de la prensa: El Argos de Buenos Aires, 1821-1825.In: ALONSO, Paula (comp.). Construcciones impresas. Pafletos, diarios y revistas en la formación de los estados nacioanales in América Latina, 1820-1920. Buenos Aires: Fundo de Cultura económica de Argentina, S.A., 2003.

NABUCO, Joaquim. Um estadista do Império. 4a . Edição. Rio de Janeiro: Aguilar, 1975.

NEVES, Lucia Maria Bastos Pereira das. Corcundas e constitucionais. A cultura política da Independência, 1820-1823. Rio de Janeiro: Revan/Faperj, 2003.

O Conselho de Estado e a política externa. Consultas da seção dos negócios estrangeiros (1858-1862). Brasília: Fundação Alexandre de Gusmão, 2005.

PEREIRA, Miguel Baptista. Modernidade e tempo. Para uma leitura do discurso moderno. Coimbra: Livraria Minerva, 1990.

PIMENTA, João Paulo Garrido. Estado e Nação no fim dos Impérios Ibéricos no Prata (1808-1828). São Paulo: Hucitec, Fapesp, 2002. 
POMBO, Rocha. História do Brasil. Rio de Janeiro, São Paulo, Porto Alegre: W. M. Jackson Inc, 1959.

PRADO JUNIOR, Caio. Formação do Brasil contemporâneo. $7^{\mathrm{a}}$ ed, São Paulo: Brasiliense, 1963.

PRADO, Maria Lígia Coelho. América latina no século XIX. Tramas, telas e textos. São Paulo: EDUS/EDUSC, 1999.

Simón Rodrigues. Mestre das primeiras letras e as idéias sem fronteiras. In: FREIAS, Marcos Cezar de; KUHLMAN, Moysés (Org.). Os intelectuais na história da infância. São Paulo: Cortez, 2002.

Bolívar em várias versões. Mais, Folha de São Paulo, 21 de janeiro de 2007.

PROENÇA, M. Cavalcanti. José de Alencar na literatura brasileira. In: José de Alencar. Ficção completa. Rio de Janeiro: Aguilar, 1965.

RENAN, Ernest. O que é uma nação? In: ROUANET, Maria Helena (Org.). Nacionalidade em questão. Cadernos da Pós/Letras. Rio de Janeiro: UERJ - Instituto de Letras, 1990.

RESENDE, Francisco de Paula Ferreira de. Minhas recordações. Rio de Janeiro: José Olympio, 1944.

REVEL, Jacques. Microanálise e construção social. In: REVEL, Jacques. Jogos de escala. A experiência da microanálise. Rio de Janeiro: Fundação Getúlio Vargas, 1998.

RICOEUR, Paul. O único e o singular. São Paulo: Editora Unesco/Pará: Editora da Universidade Estadual do Pará, 2002.

RICÚPERO, Bernardo. O romantismo e a idéia de nação no Brasil (1830-1870). São Paulo, Martins Fontes, 2004.

RIVAS, Ricardo Alberto. Abreu e Lima, Paez y la elite Argentina. Disponível em: <www.ifch.br/anphlac/anias/encontro3/esnsaio22.htm>. Acesso em: 08 Ago. 2005. 
RIVERA, Antonio Aguilar. Vicente Rocafuerte, los panfletos y la invención de la república hispanoamericana, 1821-1823. In: ALONSO, Paula (Comp.) Construcciones impresas. Pafletos, diarios y revistas en la formación de los estados nacioanales in América Latina, 1820-1920. Buenos Aires: Fundo de Cutura económica de Argentina, S.A., 2003.

ROCHA, Justiniano José da Rocha. Ação, reação, transação. Duas palavras acerca da atualidade política. In: MAGALHÃES JUNIOR, Raimundo (Org.). Três panfletários do Segundo Reinado. São Paulo: Cia. Editora Nacional, 1956.

RODRIGUES, José Honório. Teoria da História do Brasil (Introdução metodológica). 2. ed. São Paulo: Cia Editora Nacional, 1957.

ROMERO, Sílvio. Revista Brasileira. Rio de Janeiro, 1880.

RUGENDAS, João Maurício Viagem pitoresca através do Brasil. 6a. ed. São Paulo: Martins, 1967.

SAID, Edward W. Orientalismo. O oriente como invenção do ocidente. São Paulo: Cia das Letras, 1996.

SAINT-HILAIRE, Auguste de. Viagem pelo distrito dos diamantes e litoral do Brasil. Belo Horizonte: Itatiaia; São Paulo: EDUSP, 1974.

SEIDLER, Carlos. História das guerras e revoluções do Brasil de 1825 a 1835. São Paulo: Cia. Editora Nacional, 1935.

SILVA, José Bonifácio de Andrada e. Representação à Assembléia Geral Constituinte e Legislativa do Império do Brasil sobre a escravatura, in Octávio Tarquínio de Souza (Org.). O pensamento vivo de José Bonifácio. São Paulo, 1945.

SISSON, S.A. (ed.) Galeria dos brasileiros ilustres. Brasília: Senado Federal, 1999, v. 1, p. 250.

SOUZA, Adriana Barreto de. Caxias e a formação do Império do Brasil. Um estudo sobre a trajetória, configuração e ação política. Tese de Doutoramento em História. Instituto de Filosofia e Ciências Sociais da Universidade do Rio de Janeiro, 2004. Mimeografado. 
SOUZA, Iara Lis C. Pátria Coroada. O Brasil como corpo político autônomo. São Paulo: Unesp, 1999a. Mimeografado.

SOUZA, Octávio Tarquínio de. Evaristo da Veiga. São Paulo: Nacional, 1939.

(Org.). O pensamento vivo de José Bonifácio. São Paulo, 1945.

Três golpes de estado. Rio de Janeiro: José Olympio, 1957.

SOUZA, Roberto Acízelo de. O império da eloquência. RJ: EdUERJ, 1999b

SUSSEKIND, Flora. O escritor como genealogista: a função da literatura e a língua literária no romantismo brasileiro. In: PIZARRO, Ana (Org.). América latina: palavra, literatura e cultura. Campinas: EdUnicamp, 1994, v. 2.

THOMPSON, E. P. A formação da classe operária inglesa. Rio de Janeiro: Paz e Terra, 1987.

VARNHAGEN, Francisco Adolfo de. História Geral do Brasil. 9 ed. São Paulo: Melhoramentos, 1978, v.2.

Primeiro Juízo. In Revista do IHGB. T. VI, 1844, p. 60-83.

VELHO, Gilbero. Projeto e metamorfose. Rio de Janeiro: J. Zahar, 1994.

\section{SITES}

www.sobiografias.hpg.ig.com.br

www.congresobolivariano.org

www.ifch.unicamp.br

www.ihgal.al.org.br

www.radiobras.gov.br

www.pucrs.br

www.simon-bolivar.org 